C

\section{THE CAMARGO FOUNDATION}

1, Avenue Jermini, 13260, Cassis, France Tel: (33) 442011311

Email: apply@camargofoundation.org

Website: www.camargofoundation.org

Contact: Cynthia A. Gehrig, President

The Camargo Foundation is a residential center offering programming in the humanities and the arts.

\section{The Camargo Foundation Fellowships for Scholars and Artists}

Subjects: Applications are welcome from scholars working in French and Francophone cultures, including cross-cultural studies that engage the cultures and influences of the Mediterranean region and from visual artists, creative writers, film/video/new media directors, playwrights, composer, choreographers, and multidisciplinary artists. Purpose: The Camargo Foundation Fellowships are intended to give fellows the time and space they need to realise their specific objectives and projects, within a vibrant cross disciplinary intellectual context. Eligibility: The Camargo Foundation welcomes scholars and artists from all countries and nationalities as well as all career levels. Level of Study: Postgraduate, Doctorate, Professional development, Postdoctorate

Type: Fellowship

Value: US $\$ 1,500$ and residential grant

Length of Study: Between 1 and 3 months

Frequency: Annual

Study Establishment: The Camargo Foundation, Cassis, France Country of Study: France

No. of awards offered: Varies, approx. 20

Application Procedure: Applicants should apply via the online application system accessible from the Foundation's website. For further information applicants should visit the Foundation's website. Closing Date: Winter

Funding: Private

Contributor: The Jerome Hill Endowment

Additional Information: Fellows are required to remain in residence at the Foundation for the duration of their Fellowship. Each fellow must give a presentation of their project once during their fellowship, followed by a discussion. Attendance at the weekly project discussions is obligatory. A written report is required at the end of the stay.

\section{THE CANADA COUNCIL FOR THE ARTS}

150 Elgin St., PO Box 1047, Ottawa, ON, K1P 5V8, Canada Tel: (1) 8002635588 or 6135664414 , ext. 0

Fax: (1) 6135664390

Email: info@canadacouncil.ca

Website: www.canadacouncil.ca Contact: Bélanger Martin, Program Officer

The Canada Council for the Arts is a national agency that provides grants and services to professional Canadian artists and art organizations in dance, media arts, music, theatre, writing and publishing, inter-arts and the visual arts.

\section{Canada Council Grants for Professional Artists}

Subjects: Arts: dance, music, theatre, media arts, visual arts, creative writing and inter-arts.

Purpose: To help professional Canadian artists pursue professional development and/or independent artistic creation or production.

Eligibility: Open to Canadian citizens or permanent residents of Canada who have finished their basic training in the arts and/or are recognized as professionals within their own disciplines.

Level of Study: Postgraduate, Professional development

Value: Canadian $\$ 3,000-60,000$

Frequency: Varies

Country of Study: Any country

No. of awards offered: Varies

Closing Date: Varies

Funding: Government
Additional Information: Interested Canadian individuals should see the website for detailed information on the grants offered in each discipline. Please check at http://canadacouncil.ca/en/council/grants/ find-a-grant.

\section{Canada Council Michael Measures Prize \\ Subjects: Music.}

Purpose: To recognize promising young performers of classical music.

Eligibility: One recipient is selected annually from the students of the National Youth Orchestra of Canada who are between the ages of 16 and 22 and who have successfully completed the annual summer training program. Please check website for more details.

Type: Prize

Value: Prize valued up to $\$ 25,000$

Frequency: Annual

Study Establishment: Canada Council for the Arts

Country of Study: Canada

No. of awards offered: 1

Closing Date: Please check website

Funding: Private

No. of awards given last year: 1

Additional Information: Please check at http://canadacouncil.ca/en/ council/grants/find-a-grant for further information.

\section{Canada Council Travel Grants}

Subjects: Arts: dance, music, theatre, media art, visual art, creative writing and inter-arts.

Purpose: To enable Canadian artists to travel on occasions important to their professional careers.

Eligibility: Open to Canadian citizens or permanent residents of Canada who have finished their basic training in the arts and are recognized as professionals within their own disciplines

Type: Travel grant

Value: A maximum of Canadian $\$ 2,500$ to cover travel costs

Frequency: Varies

Country of Study: Any country

No. of awards offered: Varies

Closing Date: February 1st, April 1st, June 1st, September 1st, and November 1st

Funding: Government

Additional Information: Interested Canadian individuals should see the website for detailed information on the grants offered within each discipline. Please check at http://canadacouncil.ca/en/council/grants/ find-a-grant.

\section{J B C Watkins Award}

Subjects: Architecture, music, and theatre.

Purpose: To allow Canadian artists to pursue graduate study outside Canada in theatre, architecture and music.

Eligibility: Open to Canadian artists who are graduates of a Canadian university or postsecondary art institution or training school in the above subjects.

Level of Study: Postgraduate

Type: Grant

Value: Canadian $\$ 5,000$

Frequency: Annual

No. of awards offered: Varies

Application Procedure: Applicants must see the Canada Council's website http://canadacouncil.ca/council/prizes/find-a-prize/prizes/jbcwatkins-award for details.

Closing Date: Varies

Funding: Private

Additional Information: All eligible candidates in the grants to individual program within the discipline of music, theatre or architecture will automatically be considered.

\section{John G. Diefenbaker Award}

Purpose: The John G. Diefenbaker Award is funded by an endowment given to the Canada Council for the Arts by the Government of Canada. The endowment, announced by Prime Minister Brian Mulroney during his visit to Germany in the spring of 1991, honours the memory of former Prime Minister John G. Diefenbaker. The award is given annually, and it enables a distinguished German scholar to do research in Canada, which may include brief periods in the United States. The spirit of the 
award is to encourage exchange between scholarly communities in Canada and Germany.

Eligibility: Candidates may not apply for this award: they must be nominated by a department within a host university or research institute in Canada. This award is open to German scholars who have demonstrated outstanding ability, especially through a substantial publication record over several years. The award is offered in support of research in any of the disciplines of the social sciences and humanities. Candidates must be German citizens with a contractual or working relationship with an academic institution in Germany. They must have a sound working knowledge of at least one of Canada's two official languages.

Value: Up to $\$ 95,000$

Application Procedure: Check website for more details.

Closing Date: November 1st

\section{John Hobday Awards in Arts Management}

Purpose: Established through a donation of $\$ 1,000,000$ from The Samuel and Saidye Bronfman Family Foundation to the Canada Council for the Arts, the awards recognize outstanding established and mid-career arts managers in Canadian professional arts organizations. Arts managers from any artistic discipline supported by the Canada Council may apply for the awards, which are intended for professional development, mentoring and related purposes.

Eligibility: Applicants should be a Canadian citizen or have permanent resident status, as defined by Citizenship and Immigration Canada. You do not need to be living in Canada when you apply. Applicants should have a minimum of 10 years' experience (not necessarily continuous years) as a professional arts manager. Level of Study: Postgraduate

Type: Cash prize

Value: Two awards of $\$ 10,000$ each may be given annually

Frequency: Annual

Country of Study: Canada

Closing Date: September 30th

\section{Killam Prizes}

Subjects: Health sciences, natural sciences, engineering, social sciences, and humanities.

Purpose: Intended to honour eminent Canadian scholars actively engaged in research in Canada in universities, hospitals, research and scientific institutes or other equivalent or similar institutions.

Eligibility: Only Canadian citizens are eligible for this honour, and the prizes are awarded only to living candidates. To be nominated for the prizes, candidates must have made a substantial and distinguished contribution, over a significant period, to scholarly research in Canada. Their outstanding achievements must have been clearly demonstrated already, and they are expected to make further contributions to the scholarly and scientific heritage of Canada.

Level of Study: Postgraduate

Type: Prize

Value: Canadian $\$ 100,000$ (1 prize in each of the 5 fields)

Length of Study: Varies

Frequency: Annual

Study Establishment: Universities, hospitals, research institutes or scientific institutes

Country of Study: Canada

No. of awards offered: 5

Application Procedure: Candidates may not apply on their own behalf; they must be nominated by an expert in their field. Information is available on the Canada Council website.

Closing Date: June 15th

Funding: Private

Contributor: Killam Trust

No. of awards given last year: 5

Additional Information: Please check at http://canadacouncil.ca/en/ council/grants/find-a-grant for further information.

\section{Killam Research Fellowships}

Subjects: Humanities, social sciences, natural sciences, health sciences, engineering and studies linking any of the disciplines within these broad fields.

Purpose: To support Canadian scholars of exceptional ability engaged in advanced research projects.

Eligibility: Open to Canadian citizens or permanent residents of Canada. Killam Research Fellowships are aimed at established scholars who have demonstrated outstanding ability through substantial publications in their fields over a period of several years. Level of Study: Postgraduate

Type: Fellowship

Value: Canadian $\$ 70,000$ per year, paid to the university or research institution which employs the fellow

Length of Study: 2 years

Frequency: Annual

No. of awards offered: Varies

Application Procedure: There are no hard copy application forms: applicants must submit their requests through the Canada Council's online application system at killam.canadacouncil.ca.

Closing Date: May 15th

Funding: Private

Contributor: Killam Trust

Additional Information: Please check at http://canadacouncil.ca/en/ council/grants/find-a-grant for further information.

\section{Musical Instrument Bank}

Purpose: Every 3 years, talented Canadian classical musicians compete for the chance to borrow legendary instruments from the Canada Council's Musical Instrument Bank (MIB). The competition is intense and is decided by a jury of professional musicians and peers. Musicians who win the competition are often invited to perform with their instruments on some of the world's most celebrated stages. The MIB includes over 20 magnificent instruments worth a total of over $\$ 41,000,000$. These violins, cellos and bows, created by such master craftsmen as Stradivari, Gagliano and Pressenda, have been donated or lent to the MIB since it was created in 1985.

Eligibility: Applicants to some grant programs are eligible and will be considered for prizes and apply to the Council.

Level of Study: Doctorate

Value: Visit the website http://instrumentbank.canadacouncil.ca/,

to learn about the instruments

Country of Study: Canada

Closing Date: April 1st

\section{Prix de Rome in Architecture for Emerging Practitioners}

Purpose: The Canada Council for the Arts Prix de Rome in Architecture for Emerging Practitioners is awarded to a recent graduate of a Canadian school of architecture who demonstrates exceptional potential in contemporary architectural design.

Eligibility: Applicants must be a Canadian citizen or have Permanent Resident status, as defined by Citizenship and Immigration Canada. Value: The prize is $\$ 34,000$, to contribute towards the costs of the proposed program of work and related travels, and of the proposed public presentation.

Closing Date: October 1st

Additional Information: Should have received a professional Bachelor or Master degree from a Canadian school of architecture that is certified by the Canadian Architectural Certification Board within 14 months prior to the deadline for submitting applications.

\section{Robert Fleming Prize}

Subjects: Composition in classical music.

Purpose: To encourage young Canadian composers.

Eligibility: It is intended to encourage the career development of young composers and is awarded to the most talented Canadian music composer in the competition for Canada Council Grants to

Professional musicians in classical music.

Level of Study: Postgraduate

Type: Prize

Value: Canadian $\$ 2,000$

Length of Study: Up to 1 year

Frequency: Annual

Country of Study: Any country

No. of awards offered: 1

Closing Date: Please check website

Funding: Government

Additional Information: Artists may not apply for this prize. All successful candidates in the Canada Council Grants to professional musicians in classical music are considered automatically. Please check at http://canadacouncil.ca/en/council/grants/find-a-grant for further information. 


\section{THE CANADIAN ASSOCIATION FOR GRADUATE STUDIES (CAGS)}

301-260, St-Patrick Street, Ottawa, ON, K1N 5K5, Canada Tel: (1) 6135620949

Fax: (1) 6135629009

Email: info@cags.ca

Website: www.cags.ca

Canadian Association for Graduate Studies (CAGS) brings together 52 Canadian universities with graduate and post graduate programmes and 3 national graduate student associations. Its mandate is to promote graduate and post graduate education and research in Canada.

\section{CAGS UMI Dissertation Awards}

Subjects: Engineering, medical sciences and the natural sciences, fine arts, humanities and social sciences.

Purpose: To recognize Canadian Doctoral dissertations that make unusually significant and original contributions to the related academic field.

Eligibility: Open to students whose dissertation is completed and accepted by a Canadian graduate school.

Level of Study: Doctorate

Type: Award

Value: $\$ 1,500$ prize, a Citation Certificate and travel expenses of up to $\$ 1,500$ to attend the CAGS Annual Conference

Frequency: Annual

Country of Study: Canada

No. of awards offered: 2 ; There are two awards: one for engineering, medical sciences and natural sciences; and one for fine arts,

humanities and social sciences

Application Procedure: Applications must be submitted by a

Canadian university.

Closing Date: Fabruary 15th

Funding: Corporation, private

Contributor: University Microfilms International

No. of awards given last year: 2

No. of applicants last year: 50

Additional Information: Please check at www.cags.ca/cagsumi.php for further details.

\section{CANADIAN ASSOCIATION FOR THE PRACTICAL STUDY OF LAW IN EDUCATION (CAPSLE)}

37 Moultrey Crescent, Georgetown, Ontario, L7G 4N4, Canada Tel: (1) 9057021710

Fax: (1) 9058730662

Email: info@capsle.ca

Website: http://capsle.ca

Contact: CAPSLE Secretariat

CAPSLE is a national organization whose aim is to provide an open forum for the practical study of legal issues related to and affecting the education system and its stakeholders. Our members include teachers, administrators, board members, trustees, unions, school board associations, educators, academics, students, government and lawyers.

\section{CAPSLE Fellowship}

Purpose: CAPSLE is devoted to providing an open forum for the practical study of legal issues affecting education.

Eligibility: Applicants must be Canadian citizens or landed immigrants enroled in a Faculty of Law or a Graduate School of Education or related discipline at a Canadian university.

Type: Fellowship

Value: Canadian $\$ 5,000$

Frequency: Annual

\section{No. of awards offered: 1}

Application Procedure: Applicants must submit a one-page proposal for a paper, project, or research etc. that is applicable to current practical issues in education law; exhibits academic rigor; is concerned with new or ongoing research or study and not with work that is already complete; must be complete by April of the year following the award; and includes plans for a final paper which will be presented at a CAPSLE Annual Conference. Applicants must also attach a two-page curriculum vitae and three letters of reference attesting to the applicant's ability to successfully complete the project proposed. Applicants should send proposals postmarked no later than the deadline to CAPSLE.

Closing Date: April 15th

Additional Information: The successful applicant will present his or her paper at the annual conference. For detailed information, please visit http://capsle.ca/?page_id $=50$.

\section{CANADIAN ASSOCIATION OF BROADCASTERS (CAB)}

\author{
770-45 O'Connor St., Ottawa, ON, K1P 1A4, Canada \\ Tel: (1) 6132334035 \\ Fax: (1) 6132336961 \\ Email: cab@cab-acr.ca \\ Website: www.cab-acr.ca \\ Contact: Vanessa Dawson, Special Events and \\ Projects Co-ordinator
}

The Canadian Association of Broadcasters (CAB) is the collective voice of Canada's private radio and television stations and speciality services. The CAB develops industry-wide strategic plans, works to improve the financial health of the industry, and promotes private broadcasting's role as Canada's leading programmer and local service provider.

\section{BBM Scholarship}

Subjects: Statistical and quantitative research methodology. Purpose: To ensure that there is an investment in the development of individuals, skilled and knowledgeable in research, who may be of future benefit to the Canadian broadcasting industry.

Eligibility: Open to students enroled in a graduate studies programme, or in the final year of an Honours degree with the intention of entering a graduate programme, anywhere in Canada. Candidates must have demonstrated achievement in, and knowledge of, statistical and/or quantitative research methodology in a course of study at a Canadian university or postsecondary institution.

Level of Study: Graduate

Type: Scholarship

Value: Canadian $\$ 2,500-4,000$ plus a commemorative certificate

Frequency: Annual

Country of Study: Canada

No. of awards offered: 1

Application Procedure: Applicants must complete an application form and submit a 250-word essay outlining their interest in audience research. Application forms are available from the website. Three references should be attached to the completed application form, including one from the course director.

Closing Date: June 30th

Funding: Private

Contributor: The BBM Bureau of Measurement and the Canadian Association of Broadcasters

\section{CANADIAN BAR ASSOCIATION (CBA)}

500-865 Carling Avenue, Ottawa, ON, K1S 5S8, Canada Tel: (1) 6132372925,6132371988

Fax: (1) 6132370185

Email: info@cba.org

Website: www.cba.org

Contact: Christine Sopora, Project Officer Communications

The Canadian Bar Association (CBA) represents more than 37,000 lawyers across Canada. Offers national perspective on legal issues, federal legislation and trends in law. Provides explanations, analysis and commentary on all areas of law from practising lawyers,

academics and in-house counsel. CBA is dedicated to improvement in the law, the administration of justice, lawyer education and advocacy in the public interest.

\section{Viscount Bennett Fellowship}

Subjects: Law.

Purpose: To encourage a high standard of legal education, training and ethics.

Eligibility: Open to Canadian citizens only. 
Level of Study: Postgraduate

Type: Fellowship

Value: Canadian $\$ 40,000$

Length of Study: 1 year

Frequency: Annual

Study Establishment: An approved institution

Country of Study: Any country

No. of awards offered: 1

Application Procedure: Please refer to website for full details and an application form.

Closing Date: November 15th

Funding: Trusts

No. of awards given last year: 1

No. of applicants last year: Average 48

Additional Information: Please check at www.cba.org/cba/awards/ viscount bennett/ for further details.

\section{CANADIAN BLOOD SERVICES (CBS)}

\author{
1800 Alta Vista Drive, Ottawa, ON, K1G 4J5, Canada \\ Tel: (1) 6137392300 \\ Fax: (1) 6137311411 \\ Email: onematch@blood.ca \\ Website: www.bloodservices.ca
}

Canadian Blood Services (CBS) is a non-profit, charitable organization whose sole mission is to manage the blood system for Canadians. CBS collects approx. 900,000 units of blood annually and processes it into components and products that are administered to thousands of patients each year.

\section{CBS Graduate Fellowship Program}

Subjects: Blood transfusion science focusing on aspects of the collection and preparation of blood from volunteer donors as well as on the biological materials derived from blood or their substitutes obtained through biotechnology. Research may encompass a broad variety of disciplines including, but not restricted to, epidemiology, surveillance, social sciences, blood banking, immunohaematology, haematology, infectious diseases, immunology, genetics, protein chemistry, molecular and cell biology, clinical medicine, laboratory sciences, virology, bioengineering, process engineering or biotechnology.

Purpose: To attract and support young investigators to initiate or continue training in the field of blood or blood products research. Eligibility: Open to graduate students who are undertaking full-time research training leading to $\mathrm{PhD}$ degree. Students registering solely for a Master's degree will not be considered and only those demonstrating acceptance into a $\mathrm{PhD}$ programme will receive continued support. Candidates must have completed sufficient academic work to be admitted in good standing to a graduate school by the time the award is to take effect, or be already engaged in a $\mathrm{PhD}$ programme. Applicants possessing a medical degree but not licensed to practice medicine in Canada are eligible to apply for this award providing they meet the above criteria.

Level of Study: Graduate

Type: Fellowship

Value: Canadian $\$ 21,000$ per year plus a yearly research and travel allowance of Canadian $\$ 1,000$ per year

Length of Study: Up to 4 years. The initial term is for 2 years, with the option for a 2-year renewal. Renewals must be requested in the form of a complete new application

Frequency: Biannual

Country of Study: Canada

No. of awards offered: Varies

Application Procedure: Candidates are required to submit a completed application form (GFP-01) that is available either from the website, from or the main address.

Closing Date: November 15th

Funding: Government

No. of awards given last year: 7

No. of applicants last year: 15

Additional Information: Please check at www.blood.ca/en/research/ funding-programs for further details.

\section{For further information contact:}

Program Assistant, R\&D, Canadian Blood Services, 1800 Alta Vista Drive, Ottawa, ON, K1G 4J5
Tel: 6137392230

Fax: 6137392201

Email: elaine.konecny@blood.ca

Contact: Elaine Konecny

\section{CBS Postdoctoral Fellowship (PDF)}

Subjects: Transfusion science. The CBS has active research programmes within transfusion science emphasizing platelets, stem cells, plasma proteins, infectious disease, epidemiology and transfusion practice.

Purpose: To support Fellows working with CBS-affiliated research and development groups across Canada and to foster careers related to transfusion science in Canada.

Eligibility: Candidates must hold a recent $\mathrm{PhD}$ or equivalent research degree or an MD, DDS, DVM, plus a recent research degree in an appropriate health field (minimum of a MSc) or equivalent research experience, neither must be registered for a higher degree at the time of acceptance of the award and nor undertake formal studies for such a degree during the period of appointment.

Level of Study: Postdoctorate, Professional development

Type: Fellowship

Value: The value of each fellowship is related to the major degree(s) and experience that the applicant holds. The fellowship offers a stipend based on current Medical Research Council rates for each of the 3 years as well as a 1st year research allowance of Canadian $\$ 10,000$

Length of Study: 2 years with the possibility of a 1-year renewal Frequency: Annual

Country of Study: Canada

No. of awards offered: Varies

Application Procedure: Applicants must complete CBS Form RD40. Applications must be made through and with the support of a CBSaffiliated scientist. Application forms and guidelines are available from any of the CBS centres or from the main address.

Closing Date: July 6th

Funding: Government

No. of awards given last year: 4

No. of applicants last year: 8

Additional Information: Please check at www.blood.ca/en/research/ funding-programs for further details.

\section{CANADIAN BUREAU FOR INTERNATIONAL EDUCATION (CBIE)}

220 Laurier West, Suite 1550, Ottawa, ON, K1P 5Z9, Canada Tel: (1) 6132374820

Fax: (1) 6132371073

Email: scholarships-bourses@cbie.ca Website: www.cbie.ca

The Canadian Bureau for International Education (CBIE) is a national non-profit association comprising educational institutions, organizations and individuals dedicated to internal education and intercultural training. CBIE's mission is to promote the free movement of learners and trainees across national borders.

\section{Canada-Brazil Awards - Joint Research Projects}

Purpose: The Canada-Brazil Awards - Joint Research Projects support exchanges of PhD students in the context of team based bilateral research projects. The projects must engage in collaborative research in key academic areas of bilateral cooperation leading to an eventual publication or collaborative research in line with the objectives of the Canada-Brazil Framework Agreement for Cooperation on Science, Technology and Innovation. Applicants must clearly explain the advantages of the partnership for both countries.

Eligibility: This competition is open to research teams from Canadian and Brazilian universities. The coordination of the project will be the responsibility of both the Canadian and Brazilian Project Leads and the teams will consist of PhD students from both institutions. Canadian and Brazilian Project Members: Must be citizens or permanent residents of the country of their institution; Must be doctoral students Master's students and post-doctoral researchers will not be considered; Must be enrolled full-time at a post-secondary institution in their country of origin and paying the tuition fees required by that institution 
for the full duration of the exchange; Must be proficient in the language of instruction at the Canadian institution (English or French). Students already participating in an exchange program in Canada or in Brazil are not eligible.

Level of Study: Research

Value: $\$ 9,700$ for Canadian PhD students; for values for Brazilian students see: external link

Length of Study: 2 years

No. of awards offered: 5

Closing Date: July 3rd

Funding: Government

Contributor: Government of Canada, Foreign Affairs, Trade and Development Canada (DFATD)

\section{Canada-Brazil Science without Borders Scholarship \\ Program}

Subjects: All subjects.

Purpose: The programe main goal is to consolidate and expand science, technology and innovation in Brazil by means of international exchange and mobility.

Eligibility: The program will offer 101,000 scholarships to Brazilians to study, intern and conduct research in selected countries over a 4 year period.

Level of Study: Postgraduate

Type: Scholarship

Value: Total $\$ 12,000,000$ per year

Length of Study: 4 years

Frequency: Annual

Country of Study: Any country

No. of awards offered: 101,000 scholarships to Brazilians

Application Procedure: Further information available on the website. Closing Date: Please check website

Funding: Government

Contributor: Brazilian Federal Government

Additional Information: Please check at www.cbie.ca/what-we-do/ student-portal/kuwait/scholarships/ for further information.

\section{Canada-CARICOM Faculty Leadership Program}

Purpose: To support international collaboration between Canadian post-secondary institutions and institutions in the CARICOM, through professional development opportunities for faculty and staff. Eligibility: This competition is open to research teams from Canadian and Brazilian universities. The coordination of the project will be the responsibility of both the Canadian and Brazilian Project Leads and the teams will consist of graduate project members from Canadian institutions and $\mathrm{PhD}$ project members from Brazilian institutions.

Value: $\$ 2,700$ CAN for faculty members for 2 to 3 weeks of course work or research as part of their professional development; $\$ 2,700$ CAN for international directors, managers or administrators for 2 to 3 weeks of course work, or for a practicum in the area of internationalization of post-secondary institutions or student mobility as part of their professional development; or $\$ 9,700$ CAN for faculty members for 5 to 6 months of study or research at the graduate level. Closing Date: April 25th

Contributor: Global Affairs Canada: the Department of Foreign Affairs, Trade and Development (DFATD)

Additional Information: Further information is available on the International Scholarships Canada Application Tool Help webpages. If institutions experience difficulty filling out or submitting the form, they should send an email to admin-scholarships-bourses@cbie.ca.

\section{Canada-CARICOM Leadership Scholarships Program}

Eligibility: Candidates must be citizens of one of the following eligible CARICOM countries: Anguilla, Antigua and Barbuda, Bahamas, Barbados, Belize, Bermuda, British Virgin Islands, Cayman Islands, Dominica, Grenada, Guyana, Haiti, Jamaica, Montserrat, Saint Kitts and Nevis, Saint Lucia, Saint Vincent and the Grenadines, Suriname, Trinidad and Tobago, Turks and Caicos.

Value: $\$ 7,200$ CAN for college, undergraduate or graduate (Master's and $\mathrm{PhD}$ ) students for a minimum of 4 months or 1 academic term of study or research; $\$ 9,700$ CAN for graduate students (Master's and $\mathrm{PhD}$ ) for a period of 5 or 6 months of study or research; or $\$ 14,700$ CAN for undergraduate and college students for a period of 8 months of study or research.
Closing Date: April 25th

Additional Information: If institutions experience difficulty filling out or submitting the form, they should send an email to adminscholarships-bourses@cbie.ca. Further information is available on the International Scholarships Canada Application Tool Help webpages.

\section{Canada-Chile Leadership Exchange Scholarship}

Purpose: The Canada-Chile Leadership Exchange Scholarship program provides students and researchers from Chile with short-term exchange opportunities for study or research, in Canada, at the college, undergraduate and graduate levels.

Eligibility: Must be citizens of Chile. Must be enrolled full-time at a post-secondary institution in Chile and paying any tuition fees regulated by that institution for the full duration of the exchange. Value: $\$ 7,200$ CAN for college, undergraduate or graduate students (Master's and PhD) for a minimum of 4 months or 1 academic term of study or research; or $\$ 9,700$ CAN for graduate students (Master's and $\mathrm{PhD}$ ) for a period of 5 to 6 months of study or research.

Closing Date: April 25th

Additional Information: If institutions experience difficulty filling out or submitting the form, they should send an email to adminscholarships-bourses@cbie.ca. Further information is available on the International Scholarships Canada Application Tool Help webpages.

\section{Emerging Leaders in the Americas Program (ELAP)}

Purpose: The Emerging Leaders in the Americas Program (ELAP) scholarships provide students and researchers from Latin America and the Caribbean with short-term exchange opportunities for study or research, in Canada, at the college, undergraduate and graduate levels.

Eligibility: Candidates who have obtained Canadian citizenship or who have applied for permanent residency in Canada are not eligible; candidates who have already participating in an exchange scholarship program funded by the Government of Canada are not eligible; candidates who have already enrolled in a degree or diploma program at a Canadian university or college are not eligible; and the candidates must be enrolled full-time at a post-secondary institution in an eligible country and paying any tuition fees regulated by that institution for the full duration of the exchange.

Level of Study: Postgraduate

Type: Scholarship

Value: $\$ 7,200$ CAN for college, undergraduate or graduate students (Master's and PhD), or \$9,700 CAN for graduate students (Master's and $\mathrm{PhD}$ )

Length of Study: 4 months to 1 academic year (master's and PhD)/ 5 to 6 months of study of research

Country of Study: Canada

Application Procedure: If institutions experience difficulty filling out or submitting the form, they should send an email to adminscholarships-bourses@cbie.ca. Further information is available on the International Scholarships Canada Application Tool Help (http://www.scholarships-bourses.gc.ca/scholarships-bourses/app/ help-aide.aspx?lang=eng) webpages.

Closing Date: April 25th

Contributor: Government of Canada

Additional Information: As part of the Emerging Leaders in the Americas Program, selected graduate-level recipients will be invited to participate in astudy tour focused on Canadian democratic governance and civilsociety or other key priority areas.

Equal Opportunities Scholarship Program, Canada-Chile Purpose: To conduct Master's or Doctoral studies from Chile in Canada.

Eligibility: Open to Chilean citizens residing in Chile at the time of application.

Level of Study: Postgraduate

Type: Scholarship

Value: Tuition; monthly living allowance; language training in Chile (English or French) for up to 1 year; return airfare (economy class); and dependents' allowance

Length of Study: Master's level: 2 years; doctoral level: 4 years

Country of Study: Canada

No. of awards offered: 100 
Application Procedure: Direct all questions regarding the application process, deadlines and other program details to Becas Chile (http://portales.mineduc.cl/index.php?id_portal =60) (Spanish only). Contributor: Chilean Government

\section{Organization of American States (OAS) Fellowships \\ Programs}

Subjects: Human development

Purpose: To fund education of Canadian residents and nationals in other American nations.

Eligibility: Open to Canadian residents and nationals

Level of Study: Doctorate, MBA, Graduate

Type: Fellowship

Value: US $\$ 30,000$ per academic year, which includes a round-trip economy-class airfare ticket; tuition fees and mandatory expenses for the academic program, a fixed monthly allowance, medical insurance, and a fixed annual book allowance

Length of Study: 1-2 years

Frequency: Annual

Application Procedure: A completed application form must be submitted on time. Please refer website for more information.

Closing Date: March 7th

Funding: Government

Additional Information: Please check at www.cbie-bcei.ca/ what-we-do/student-portal/scholarships/ for further details.

\section{CANADIAN CANCER SOCIETY RESEARCH INSTITUTE (CCSRI)}

Suite 300, 55 St. Clair Avenue W., Toronto, Ontario, M4V 2Y7, Canada

Tel: (1) 4169617223

Fax: (1) 4169614189

Email: research@cancer.ca

Website: www.cancer.ca/research

The Canadian Cancer Society (CCS) is the largest non-government funder of cancer research in Canada. The CCS provides support for research and related programmes undertaken at Canadian universities, hospitals and other research institutions.

\section{CCS Impact Grants}

Subjects: Cancer research

Purpose: To stimulate Canadian investigators in a very broad spectrum of research.

Eligibility: A researcher who is designated as the Principal Investigator must be based in, or formally affiliated with, but not necessarily receive salary support form, an eligible Canadian Host Institution such as a university, research institute or health care agency. Graduate students, postdoctoral fellows, research associates, technical support staff, or investigators based outside of Canada are not eligible to be a Principal Investigator.

Type: Research grant

Value: Budgets awarded will not exceed $\$ 250,000$ per year, to a maximum of $\$ 1,250,000$ per grant. The grant term is up to 5 years. Grants will be renewable. Funding will be provided to support the direct costs of research, including supplies, expenses, wages and equipment associated with the proposed work. Indirect costs will not be considered eligible expenses. Equipment requests of up to $\$ 125,000$ can be included within the proposed budget.

Length of Study: 1-5 years

Frequency: Annual

Study Establishment: Universities or other institutions

Country of Study: Canada

No. of awards offered: 12

Application Procedure: Applicants must complete an online application form. Further details are available on the website.

Closing Date: check with website for more other dates

Funding: Private

Contributor: The Terry Fox Foundation and the Canadian Cancer Society

No. of awards given last year: 11

No. of applicants last year: 89

Additional Information: Further information is available on the website. Grants will be awarded to projects deemed worthy of support, provided that the basic equipment and research facilities are available in the institution concerned and that it will provide the necessary administrative services. Grants are made only with the consent and knowledge of the administrative head of the institution at which they are to be held and applications must be countersigned accordingly. Please check at www.cancer.ca/en/research/grants-and-awards/ current-funding-opportunities/impact-grants/ for further details.

\section{CCS Innovation Grants}

Subjects: Cancer research

Purpose: To stimulate Canadian investigators in a very broad spectrum of research

Eligibility: A researcher who is designated as the Principal Investigator must be based in, or formally affiliated with, but not necessarily receive salary support from, an eligible Canadian Host Institution such as a university, research institute or health care agency. Graduate students, postdoctoral fellows, research associates, technical support staff, or investigators based outside Canada are not eligible to be a principal investigator.

Type: Research grant

Value: Grant budgets may be up to $\$ 100,000$ per year and a maximum of $\$ 200,000$ per grant. Grant expenditures may be extended over 3 years if justified in the application. Grants will be nonrenewable. Funding will be provided to support the direct costs of research, including supplies, salaries, and equipment associated with the proposed work. Equipment requests cannot exceed $25 \%$ of the requested budget. Indirect costs are not eligible.

Length of Study: 2-3 years

Frequency: Biannual

Study Establishment: Universities or other institutions

Country of Study: Canada

No. of awards offered: 25

Application Procedure: Applicants must complete an online application form. Further details are available on the website.

Closing Date: October 1st (1st competition); February 15th (2nd competition)

Funding: Private

Contributor: The Canadian Cancer Society

No. of awards given last year: 37

No. of applicants last year: 204

Additional Information: Grants will be awarded to projects deemed worthy of support, provided that the basic equipment and research facilities are available in the institution concerned and that it will provide the necessary administrative services. Grants are made only with the consent and knowledge of the administrative head of the institution at which they are to be held and applications must be countersigned accordingly. Please check at www.cancer.ca/en/ research/grants-and-awards/current-funding-opportunities/innovationgrants/ for further details.

\section{CCS Travel Awards}

Subjects: Cancer research.

Purpose: To provide financial assistance by helping to defray the travel costs associated with making a scientific presentation as a first author or presenter at a conference, symposium or other appropriate professional gathering.

Eligibility: Applicants must be students enrolled in a MD/PhD program at a Canadian institution and be in the final phase of their studies. Candidates must be attending a conference for the purpose of presenting data from a cancer-related project on a first author or presenter basis. Postdoctoral fellows must be within 5 years of attaining their PhD Medical resident/clinical fellow must be within 5 years of attaining their MD.

Level of Study: Graduate, Postgraduate

Type: Travel grant

Value: Up to Canadian $\$ 2,000$

Frequency: 3 times per year (March/July/November)

Country of Study: International

No. of awards offered: Up to 30 per calendar year

Application Procedure: Applicants must refer to the website.

Closing Date: January 15th, May 15th, September 15th

Funding: Private

Contributor: The Canadian Cancer Society 
Additional Information: Please check at www.cancer.ca/en/ research/grants-and-awards/current-funding-opportunities/ travel-awards/ for further information.

\section{Knowledge to Action Grant}

Subjects: Cancer research

Purpose: Intended to provide funding for research projects that build on existing cancer research finding and aim to improve outcomes and experiences through $\mathrm{KT}$ for people and populations at risk, patients, their families and communities across the cancer trajectory. Eligibility: A researcher who is designated as the Principal Investigator (as per other CCS awards).

Level of Study: Research

Type: Grant

Value: Grants will be funded to a maximum of $\$ 100,000$ to be spent over 1 or 2 years. It is anticipated that up to 3 grants will be awarded in each competition. Budgets can include (within the funding cap) a request for permanent equipment of up to $\$ 10,000$.

Length of Study: $1-2$ years

Frequency: Annual

Study Establishment: Universities or Other Institutions

Country of Study: Canada

No. of awards offered: $3-4$

Application Procedure: Applicants must complete an online application form. Further details are available on the website.

Closing Date: Abstract registration due date: February 1st; Full application due date: April 15th

Funding: Private

Contributor: The Canadian Cancer Society

Additional Information: Please check at www.cancer.ca/en/ research/grants-and-awards/current-funding-opportunities/ knowledge-to-action-grants/ for further details.

\section{Quality of Life Research Grant}

Subjects: Cancer research.

Purpose: To support quality of life research that has the potential to make a significant impact on the burden of disease in patients, survivor and caregiver.

Eligibility: A researcher who is designated as the Principal Investigator (as per other CCS awards).

Level of Study: Research

Type: Grant

Value: Budgets awarded will not exceed $\$ 300,000$ over 2 or 3 years per grant. It is anticipated that up to 4 grants will be awarded in each competition. Funding will be provided to support the direct costs of research, including supplies, expenses, wages and equipment associated with the proposed work. Equipment requests of up to $\$ 10,000$ can be included within the proposed budget but must be appropriately justified. Grants will be renewable.

Length of Study: 3 years

Frequency: Annual

Study Establishment: Universities of Other Institutions

Country of Study: Canada

No. of awards offered: 6

Application Procedure: Applicants must complete an online application form. Further details are available on the website.

Closing Date: June 29th (letter of intent) and November 1st (full application)

Funding: Private

Contributor: The Canadian Cancer Society

No. of awards given last year: 6

No. of applicants last year: 63

Additional Information: Please check at www.cancer.ca/en/ research/grants-and-awards/current-funding-opportunities/ quality-of-life-research-grants/ for further details.

\section{CANADIAN CENTENNIAL SCHOLARSHIP FUND}

CCSF c/o Blake Cassels \& Graydon, LLP 5th Floor 23 College Hill, London, EC4R 2RP, England Tel: (44) 02074999729

Email: applications@canadianscholarshipfund.co.uk Website: www.canadianscholarshipfund.co.uk
The Canadian Centennial Scholarship Fund gives annual awards to Canadian men and women who are already studying in the UK. Scholarships are awarded on the basis of high academic standards, financial need and relevance of the proposed course of study to Canada.

\section{Canadian Centennial Scholarship Fund}

Subjects: All subjects.

Purpose: The Canadian Centennial Scholarship Fund (CCSF) provides annual awards ranging from $£ 1,000$ to $£ 5,000$ to Canadian men and women for postgraduate academic and specialist artistic study in the UK. Students interested in applying should read all the information provided on the Information for Students pages (external linkbefore proceeding with their application to ensure they are eligibility.

Eligibility: Canadian citizens currently enrolled in a United Kingdom programme of studies are eligible to apply.

Level of Study: Doctorate, Graduate, Postgraduate, MBA, Professional development

Type: Scholarship

Value: UK $£ 500-3,000$

Length of Study: Recipients may re-apply

Country of Study: United Kingdom

No. of awards offered: 12-16

Application Procedure: Candidates submit a written application and those short listed are interviewed. Applications can be downloaded from our website.

Closing Date: March 8th

Funding: Trusts

Contributor: Maple Leaf Trust

No. of awards given last year: 15

No. of applicants last year: 100

Additional Information: Please visit website

(www.canadianscholarshipfund.co.uk) for details.

\section{CANADIAN EMBASSY (USA)}

501 Pennsylvania Ave. N.W., Washington, DC, 20001-2114, United States of America

Tel: (1) 2026821740

Fax: (1) 2026827726

Email: enqserv@dfait-maeci.gc.ca

Website: www.canadianembassy.org

\section{Canadian Embassy (USA) Research Grant Program}

Subjects: Business and economic issues, Canadian values and culture, communications, environment, national and international security or natural resources, e.g. energy, fisheries, forestry and trade. Purpose: To assist individual scholars or a group of scholars in writing an article length manuscript of publishable quality and reporting their findings in scholarly publications.

Eligibility: Open to full-time faculty members at accredited 4-year US colleges and universities, as well as scholars at American research and policy planning institutes who undertake significant research projects concerning Canada, Canada and the US, or Canada and North America. Recent PhD recipients who are citizens or permanent residents of the US are also eligible to apply.

Level of Study: Postgraduate

Type: Programme grant

Value: Up to US\$15,000; applicants whose project focuses on the priority topics listed above and who can demonstrate matching funds from others sources may request funding up to US $\$ 20,000$

Frequency: Annual

Study Establishment: An accredited 4-year college or university Country of Study: United States of America

Application Procedure: Applicants must provide 6 copies of the following in this order: the completed application form, a concise proposal of 4-8 pages which will identify all members of the research team, if a team project, and specify each member's affiliation and role in the study, identify the key issues or the main theoretical problem, describe and justify the appropriate methodology, present a general schedule of research activities, indicate clearly both the nature and scope of the projects contribution to the advancement of Canadian Studies, include a detailed budget including all other funding sources 
and a description of anticipated expenditures. A curriculum vitae, and the names and addresses of two scholars from whom the applicants will solicit recommendations should also be included. Application forms are available on request.

Closing Date: November 1st

Funding: Government

Additional Information: The Research Grant Program promotes research in the social sciences and humanities with a view to contributing to a better knowledge and understanding of Canada and its relationship with the US or other countries of the world.

\section{For further information contact:}

Tel: 2026827717

Email: daniel.abele@dfait-maeci.gc.ca

Contact: Dan Abele, Academic Relations Officer

\section{Canadian Embassy Faculty Enrichment Program}

Subjects: Priority topics include bilateral trade and economics, Canada - US border issues, cultural policy and values, environment, natural resources, energy issues and security co-operation, projects that examine Canadian politics, economics, culture and society as well as Canada's role in international affairs.

Purpose: To provide faculty members with the opportunity to develop or redevelop courses with substantial Canadian content that will be offered as part of their regular teaching load, or as a special offering to select audiences in continuing or distance education.

Eligibility: Open to full-time, tenured or tenure track faculty members at accredited 4-year U.S. colleges and universities. Candidates should be able to demonstrate that they are already teaching, or will be authorized to teach, courses with substantial Canadian content (33 per cent or more). Team teaching applications are welcome. Applicants are ineligible to receive the same grant in 2 consecutive years or to receive two individual category Canadian Studies grants in the same grant period

Type: Programme

Value: Funding up to US $\$ 6,000$; applicants may request an additional US $\$ 5,000$ specifically to support student travel to Canada

Frequency: Annual

Country of Study: United States of America

No. of awards offered: Varies

Application Procedure: Applicants must contact the organization for an application form.

Closing Date: December 1st

Additional Information: The Embassy especially encourages the use of new Internet technology to enhance existing courses, including the creation of instructional websites, interactive technologies and distance learning links to Canadian Universities.

\section{For further information contact:}

Tel: 2026827717

Email: daniel.abele@dfait-maeci.gc.ca

Contact: Dan Abele, Academic Relations Officer

\section{Canadian Embassy Graduate Student Fellowship Program}

Subjects: Business and economic issues, Canadian values and culture, communications, environment, national and international security or natural resources, e.g. energy, fisheries, forestry and trade.

Purpose: To assist graduate students in conducting part of their doctoral research in Canada to acquire a better knowledge and understanding of Canada or its relationship with the US and other countries of the world.

Eligibility: Open to full-time doctoral students at accredited 4-year colleges and universities in the US or Canada whose dissertations are related in substantial part to the study of Canada, Canada and the US or Canada and North America. Candidates must be citizens or permanent residents of the US and should have completed all doctoral requirements except the dissertation when they apply for a grant.

Level of Study: Graduate

Type: Fellowship

Value: Fellowships carrying stipends of up to $\$ 850$ per month for up to 9 months
Length of Study: 9 months

Frequency: Annual

Study Establishment: An accredited 4-year college or university Country of Study: Other

Application Procedure: Applicants must provide six copies of the following in the order listed: the completed application form, a concise letter of three to four pages which will explain clearly the present status of the candidate's doctoral studies, describe the candidate's study plans in Canada, list Canadian contacts such as Scholars, research institutes, academic institutions or libraries, state clearly the exact number of months for which financial support is needed, provide a complete and detailed budget, indicate what other funding sources are available, give the names and addresses of two referees, one of which must be the dissertation advisor, contain the dissertation prospectus which must identify the key issues or the main theoretical problem, justify the methodology and indicate clearly the nature of the dissertation's contribution to the advancement of Canadian Studies. An unofficial transcript of grades, a curriculum vitae and proof of US citizenship or permanent residency must also be included. Application forms are available on request.

Closing Date: October

Funding: Government

Additional Information: The Graduate Student Fellowship Program promotes research in the social sciences and humanities with a view to contributing to a better knowledge and understanding of Canada and its relationship with the US or other countries of the world.

For further information contact:

501 Pennsylvania Avenue, NW, Washington, DC, 20001

Tel: 2026827727

Email: daniel.abele@dfait-maeci.gc.ca

Contact: Dan Abele, Academic Relations Officer

\section{Conference Grant Program}

Subjects: Social science and humanities.

Purpose: To assist an institution in holding a conference and publishing the resulting papers and proceedings in a scholarly fashion.

Eligibility: Open to U.S. institutions and universities who wish to undertake a conference on Canada-US issues.

Level of Study: Postgraduate

Type: Grant

Value: Applicants may request funding up to US $\$ 15,000$; applicants whose project focuses on the priority topics above and who can demonstrate matching funds from others sources may request funding up to US $\$ 20,000$

Frequency: Annual

Country of Study: United States of America

Application Procedure: Applicants must complete the online application form at www.international.gc.ca/studies-etudes/grantconfsubconf.aspx? view $=\mathrm{d}$.

Closing Date: Check the website

Funding: Government

Contributor: Foreign Affairs Canada

Additional Information: Proposals must be submitted in English or French and budget figures must be in Canadian dollars. Please check at www.humanities.ufl.edu/funding/june-faculty-canadian-embassygrants.html for further information.

\section{Program Enhancement Grant}

Subjects: International relations.

Purpose: To encourage innovative projects that promote awareness among students and the public about Canada-US relations.

Eligibility: Open to U.S. colleges, research institutions and universities who wish to undertake professional academic activities.

Level of Study: Postgraduate

Type: Grant

Value: Up to US $\$ 18,000$ per year

Length of Study: 1 year

Frequency: Annual

Country of Study: United States of America

Application Procedure: A completed online application form must be submitted.

Closing Date: June 15th 


\section{CANADIAN FEDERATION OF UNIVERSITY WOMEN (CFUW)}

331 Cooper Street, Suite 502, Ottawa, ON, K2P 0G5, Canada

Tel: (1) 6132348252 ext. 104

Fax: (1) 6132348221

Email: cfuwfls@rogers.com, fellowships@cfuw.org

Website: www.cfuw.org

Contact: Betty A Dunlop, CFUW Fellowships Program Manager

Found in 1919, the Canadian Federation of University Women (CFUW) is a voluntary, non-partisan, non-profit, self-funded bilingual organization of 9,000 women university graduates. CFUW members are active in public affairs, working to raise the social, economic, and legal status of women as well as to improve education, the environment, peace, justice and human rights.

\section{Canadian Home Economics Association (CHEA) \\ Fellowship}

Subjects: Home economics.

Purpose: To provide funding for studying one or more aspects in the field of home economics, at the masters or doctoral level in Canada.

Eligibility: Open to female Canadian citizens. Candidates should hold a Bachelor's degree or its equivalent from a recognized university, not necessarily in Canada or women who have permanent residence prior to the submission of an application.

Level of Study: Postgraduate

Type: Fellowship

Value: Canadian $\$ 6,000$

Frequency: Annual

Study Establishment: A recognized university

Country of Study: Canada

No. of awards offered: 1

Application Procedure: Applicants must complete an application

form, available from the Federation website.

Closing Date: November 1st

Funding: Private

No. of awards given last year: 1

No. of applicants last year: 8

Additional Information: The fellowship is not renewable.

\section{CFUW 1989 École Poytechnique Commemorative \\ Awards}

Subjects: All subjects. (The applicant must justify the relevance of her work to women.)

Purpose: To provide funding for graduate studies in any field.

Eligibility: Open to female Canadian citizens or women who have permanent residence prior to the submission of an application.

Candidates should hold a Bachelor's degree or its equivalent from a recognized university, not necessarily in Canada.

Level of Study: Postgraduate

Type: Fellowship

Value: Canadian award of $\$ 7,000$ for doctoral level study and another award of $\$ 5,000$ for masters study

Frequency: Annual

Study Establishment: A recognized university

Country of Study: Any country

No. of awards offered: 2

Application Procedure: Applicants must complete an application

form, available from the Federation website.

Closing Date: November 1st

Funding: Private

No. of awards given last year: 1

No. of applicants last year: 41

Additional Information: The fellowship is not renewable.

\section{CFUW Aboriginal Women's Award (AWA)}

Subjects: Programmes leading to a first degree in Law - Bachelor of Laws (LLB), Juris Doctor (JD). Programmes leading to the following first degrees in Medicine - Medical Doctor (MD), Doctor of Optometry (OD).Programmes leading to qualifying for a license to practice as a Nurse Practitioner in the Province of territory of the graduate's choice. Programmes leading to a Master's degree in fields dealing with important Canadian aboriginal issues at the time the AWA is given as defined by the most recent Canadian report by the United Nations Special Rapporteur on the rights of indigenous peoples.

Purpose: To provide funding for full-time study.

Eligibility: Open to female aboriginal Canadian citizen. Candidates should hold or will hold an undergraduate university degree or equivalent before the CFUW AWA for which the recipient applied is granted. Must have applied to be a full-time student in any year of an eligible program at a recognized or accredited Canadian post-

secondary degree-granting institution.

Value: Canadian $\$ 10,000-\$ 25,000$

Frequency: Every 2 years

Study Establishment: A recognized university

Country of Study: Canada

No. of awards offered: 1

Application Procedure: Candidate must complete an application

form, available from the Federation website.

Closing Date: November 1st

Funding: Private

No. of applicants last year: 14

Additional Information: The next CFUW AWA competition will open in May 2017 with an announcement on this website.

\section{CFUW Beverley Jackson Fellowship}

Subjects: All subjects. The fellowship has been transferred back to the UWC North York club/member of CFUW.

Purpose: To provide funding for graduate studies at an Ontario university.

Eligibility: Open to female Canadian citizens. Candidates should hold a Bachelor's degree or its equivalent from a recognized university, not necessarily in Canada. The applicant must be over the age of 35 . Or women who have permanent residence prior to the submission of an application.

Level of Study: Postgraduate

Type: Fellowship

Value: Canadian $\$ 2,000$

Frequency: Annual

Study Establishment: A recognized university

Country of Study: Canada

No. of awards offered: 1

Application Procedure: Applicants must complete an application form, available from the Federation website.

Closing Date: November 1st

Funding: Private

Contributor: UWC North York funds

No. of awards given last year: 1

No. of applicants last year: 5

Additional Information: The fellowship is not renewable.

\section{CFUW Bourse Georgette Lemoyne}

Subjects: All subjects. The applicant must be studying in French and write the Statement of Intent (Section I) of the application in French. Purpose: To provide funding for graduate study in any field at a Canadian university.

Eligibility: Open to female Canadian citizens. Candidates should hold a Bachelor's degree or its equivalent from a recognized university, not necessarily in Canada or women who have permanent residence prior to the submission of an application.

Level of Study: Postgraduate

Type: Fellowship

Value: Canadian $\$ 5,000$

Frequency: Annual

Study Establishment: A recognized university

Country of Study: Canada

No. of awards offered: 1

Application Procedure: Applicants must complete an application form, available from the Federation website.

Closing Date: November 1st

Funding: Private

No. of awards given last year: 1

No. of applicants last year: 12

Additional Information: The fellowship is not renewable. 


\section{CFUW Dr Alice E. Wilson Awards}

Subjects: All subjects.

Purpose: Awarded to mature students returning to graduate studies in any field, with special consideration given to those returning to study after at least 3 years.

Eligibility: Open to female Canadian citizens or women who have permanent residence prior to the submission of an application.

Candidates should hold a Bachelor's degree or its equivalent from a recognized university, not necessarily in Canada. Awarded to mature students returning to graduate studies in any field, with special consideration given to those returning to study after at least 3 years

Level of Study: Postgraduate

Type: Fellowship

Value: Canadian $\$ 5,000$

Frequency: Annual

Study Establishment: A recognized university

Country of Study: Any country

No. of awards offered: 4

Application Procedure: Applicants must complete an application

form, available from the Federation website.

Closing Date: November 1st

Funding: Private

No. of awards given last year: 4

No. of applicants last year: 49

Additional Information: The fellowship is not renewable.

\section{CFUW Elizabeth and Ruth Massey Award}

Subjects: Visual arts (e.g. painting or sculpture; or music).

Purpose: To provide funding for postgraduate studies in the visual arts, such as painting or sculpture; or in music. The award is tenable in Canada or abroad.

Eligibility: Open to female Canadian citizens. Candidates should hold a bachelor's degree or its equivalent from a recognized university, not necessarily in Canada, or women who have permanent residence prior to the submission of an application.

Level of Study: Postgraduate

Type: Award

Value: Canadian $\$ 5,000$

Frequency: Annual

Study Establishment: A recognized university

Country of Study: Any country

No. of awards offered: 1

Application Procedure: Candidates must complete an application

form, available from the Federation website.

Closing Date: November 1st

Funding: Private

Contributor: The Massey Family Funds

No. of awards given last year: 1

No. of applicants last year: 9

Additional Information: The fellowship is not renewable.

\section{CFUW Linda Souter Humanities Award}

Subjects: Humanities.

Purpose: To provide funding for graduate studies in the humanities Eligibility: Open to female Canadian citizens, or women who have permanent residence in Canada. Candidates should hold a bachelor's degree or its equivalent from a recognized university. Awarded to a masters or doctoral student studying in the areas of the humanities. Level of Study: Postgraduate

Type: Award

Value: Canadian $\$ 6,000$

Frequency: Annual

Study Establishment: A rocognized university

Country of Study: Any country

No. of awards offered: 1

Application Procedure: Candidates must complete an application form, available from the federation website.

Closing Date: November 1st

Funding: Private

Contributor: CFUW

No. of awards given last year: 1

No. of applicants last year: 19

Additional Information: This fellowship is not renewable.
CFUW Margaret Dale Philp Award

Subjects: Humanities or social sciences and Canadian history

Purpose: To provide funding for graduate studies in the humanities or social sciences. Special consideration given to study in Canadian history only as a deciding factor, all these being equal.

Eligibility: Open to female Canadian citizens. Candidates should hold a Bachelor's degree or its equivalent from a recognized university, not necessarily in Canada, or women who have permanent residence prior to the submission of an application.

Level of Study: Postgraduate

Type: Award

Value: Canadian $\$ 3,500$

Frequency: Annual

Study Establishment: A recognized university

Country of Study: Canada

No. of awards offered: 1

Application Procedure: Candidates must complete an application form, available from the Federation website.

Closing Date: November 1st

Funding: Private

Contributor: CFUW Kitchener-Waterloo funds

No. of awards given last year: 1

No. of applicants last year: 27

Additional Information: The fellowship is not renewable.

\section{CFUW Margaret McWilliams Predoctoral Fellowship}

Subjects: All subjects.

Purpose: To provide funding for full-time doctoral study.

Eligibility: Open to female Canadian citizens or women who have permanent residence prior to the submission of an application.

Candidates should hold a Bachelor's degree or its equivalent from a recognized university, not necessarily in Canada, and be a full-time student at an advanced stage, i.e. at least 1 year into her doctoral programme.

Level of Study: Doctorate

Type: Fellowship

Value: Canadian $\$ 11,000$

Frequency: Annual

Study Establishment: A recognized university

Country of Study: Any country

No. of awards offered: 1

Application Procedure: Applicants must complete an application

form, available from the Federation website.

Closing Date: November 1st

Funding: Private

No. of awards given last year: 1

No. of applicants last year: 63

Additional Information: The fellowship is not renewable. There is a new Toll-Free number in the US \& Canada: 18882209606.

\section{CFUW Memorial Fellowship}

Subjects: Science, mathematics or engineering.

Purpose: To provide funding for postgraduate degree studies in science, mathematics or engineering.

Eligibility: Open to female Canadian citizens. Candidates should hold a Bachelor's degree or its equivalent from a recognized university, not necessarily in Canada or women who have permanent residence prior to the submission of an application.

Level of Study: Postgraduate, Masters

Type: Fellowship

Value: Canadian $\$ 8,000$

Frequency: Annual

Study Establishment: A recognized university

Country of Study: Any country

No. of awards offered: 1

Application Procedure: Applicants must complete an application form, available from the Federation website.

Closing Date: November 1st

Funding: Private

No. of awards given last year: 1

No. of applicants last year: 22

Additional Information: The fellowship is not renewable. 


\section{Ruth Binnie Fellowship}

Subjects: Home economics.

Purpose: To provide funding for Master's studies with a focus on one or more aspects of home economics.

Eligibility: Open to female Canadian citizens. Candidates should hold a Bachelor's degree or its equivalent from a recognized university, not necessarily in Canada. Or women who have permanent residence prior to the submission of an application.

Level of Study: Postgraduate, Masters

Type: Fellowship

Value: Canadian $\$ 6,000$

Frequency: Annual

Study Establishment: A recognized university

Country of Study: Any country

No. of awards offered: 1

Application Procedure: Applicants must complete an application form, available from the Federation website.

Closing Date: November 1st

Funding: Private

No. of awards given last year: 1

No. of applicants last year: 6

Additional Information: The fellowship is not renewable.

\section{CANADIAN HOSPITALITY FOUNDATION}

300 Adelaide Street East, Suite 339, Toronto, ON, M5A 1N1, Canada Tel: (1) 4163633401

Fax: (1) 4163633403

Email: chf@theohi.ca

Website: www.thechf.ca/contact

The Canadian Hospitality Foundation is Canada's largest industry driven source of scholarships for students pursuing careers in the foodservice/hospitality industry.

\section{Canadian Hospitality Foundation Scholarship}

Subjects: Hotel and food administration and hospitality and tourism management.

Eligibility: Open only to Canadian citizens or Landed Immigrants. Eligible to students in 2- and 1-year college programs.

Level of Study: Postgraduate

Type: Scholarship

Value: Canadian $\$ 1,000$ up to 3,500

Frequency: Annual

Study Establishment: University of Calgary, University of Guelph, Ryerson Polytechnical Institute or Mount Saint Vincent University

Country of Study: Canada

No. of awards offered: 7

Application Procedure: More information and application forms available online.

Closing Date: March 20th

Additional Information: Please check at www.thechf.ca/ scholarships for further details.

\section{CANADIAN INITIATIVE FOR NORDIC STUDIES}

University of Alberta, 116 St. and 85 Ave., Edmonton, Alberta T6G 2R3, Canada

Tel: (1) 7804923111

Email: cins@ualberta.ca

Website: www.ualberta.ca

Contact: Natalie Van Deusen, Chair of the Board, CINS

The Canadian Initiative for Nordic Studies (CINS, formerly the Canadian Institute for Nordic Studies) was established in 1987 to promote multidisciplinary academic and cultural links among the Nordic countries of Denmark, Finland, Iceland, Norway and Sweden, as well as the Faeroe Islands and Greenland, and the University of Alberta and other Canadian universities and post-secondary institutions.

\section{CINS Graduate Scholarship}

Subjects: Fine arts, humanities, natural, physical, applied and social sciences and more.

Purpose: To provide financial assistance to students who wish to pursue higher studies.
Eligibility: Open to Canadian citizens or landed immigrants, who have completed a Bachelor's degree from a Canadian university or college with high scholastic achievement. Applicants must be in residency at the Nordic destination for a minimum of 6 months and provide a written report to CINS no later than 6 months after completing the proposed programme of study.

Level of Study: Postgraduate

Type: Scholarship

Value: Canadian $\$ 5,000$

Frequency: Annual

No. of awards offered: We offer one MA and one PhD scholarship Application Procedure: Applicants should include the following in their application: contact details, citizenship status, social insurance number and date of birth, current academic status with formal transcripts, written acceptance from the host Nordic institution and reference letters. Applicant must be a student in one of the Nordic countries: Denmark, Finland, Iceland, Norway, Sweden, the Faeroe Islands, and Greenland.

Closing Date: October 15th

No. of awards given last year: 2

Additional Information: Applicants can study at any recognized institution granting earned degrees at the postbaccalaureate level in the applicant's field of study and located in one of the Nordic countries: Denmark, Finland, Iceland, Norway, Sweden, the Faroe Islands and Greenland

\section{CANADIAN INSTITUTE FOR ADVANCED LEGAL STUDIES}

PO Box 43538, Leaside Post Office, 1601 Bayview Avenue, Toronto, ON, M4G 4G8, Canada

Tel: (1) 4164293292

Fax: (1) 4164299805

Email: info@canadian-institute.com

Website: www.canadian-institute.com

Contact: Mr Randall J. Hofley, Vice-President

The Canadian Institute for Advanced Legal Studies conducts legal seminars for judges and lawyers in Cambridge, England and Strasbourg, France.

\section{The Right Honorable Paul Martin Sr. Scholarship}

Subjects: Law.

Purpose: To study for an LLM at the University of Cambridge.

Eligibility: Open to graduates who have been awarded a law degree from a 3- or 4-year program at a faculty of law in a Canadian university in the 4 years before the candidate will commence his or her studies at the University of Cambridge (supported by The Right Honourable Paul Martin Sr. Scholarship). An applicant must be accepted into the University of Cambridge and a college of the University of Cambridge for graduate studies in law in order to receive this scholarship, although such acceptance need not be confirmed at the time of the application for the scholarship nor at the time that the Institute provides the candidate with notice that he or she has been selected to receive the scholarship.

Level of Study: Postgraduate

Type: Scholarship

Value: Canadian $\$ 23,000$

Length of Study: 1 year

Frequency: Annual

Study Establishment: The University of Cambridge

Country of Study: England

No. of awards offered: 2

Application Procedure: Applications must include curriculum vitae; a personal statement indicating why the applicant wishes to undertake graduate studies in law at the University of Cambridge and why the applicant is suited to undertake such studies; a copy of transcripts for undergraduate and graduate studies, for studies in law and for a Bar Admissions Course, as applicable; and a maximum of three letters of references.

Closing Date: December 31st

Funding: Private

No. of awards given last year: 2

No. of applicants last year: 25 
Additional Information: The scholarship may be held with another small award as approved by the Institute. Please check at www.canadian-institute.com/english/index.html for further details.

For further information contact:

Canadian Institute for Advanced Legal Studies, 1601 Bayview Avenue, Ontario, Toronto, M4G 4G8

Tel: 4164293292

Fax: 4164299805

Email: info@canadian-institute.com

Contact: Mr Randall J Hofley, Vice President

\section{CANADIAN INSTITUTE OF GEOMATICS (CIG)}

900 Dynes Road, Suite 100 D, Ottawa, ON, K2C 3L6, Canada

Tel: (1) 6132249851

Fax: (1) 6132249577

Email: exdircig@magma.ca

Website: www.cig-acsg.ca

Contact: Executive Director

The Canadian Institute of Geomatics (CIG) was founded in 1882. CIG has evolved to be a non-profit, scientific and technical association and represents the largest and most influential geospatial knowledge network in Canada. Over 50 per cent of its members are senior managers and researchers in government and private sectors, academic and NGO organizations.

\section{The Hans Klinkenberg Memorial Scholarship}

Subjects: Geomatics sciences.

Purpose: The Hans Klinkenberg Memorial Scholarship Fund provides scholarships to students in the Geomatics sciences at technical institutes and community colleges in Canada.

Eligibility: Applicants must be a Canadian citizen or a landed immigrant.

Type: Scholarship

Value: Awards range from Canadian $\$ 500$ to $\$ 2,000$

Frequency: Annual

Country of Study: Canada

No. of awards offered: 2

Application Procedure: Application can be downloaded from www. cig-acsg.ca.

Closing Date: February 15th

Funding: Trusts

Contributor: Hans Klinkenberg Memorial Fund

No. of awards given last year: 2

No. of applicants last year: 5

Additional Information: Please check at www.cig-acsg.ca/english/ scholarship/hans-klinkenberg.php for further details.

\section{CANADIAN INSTITUTES OF HEALTH RESEARCH}

160 Elgin Street, 9th Floor; Address Locator 4809A, Ottawa, ON K1A 0W9, Canada

The Canadian Institutes of Health Research (CIHR) is Canada's federal funding agency for health research. Composed of 13 Institutes, we collaborate with partners and researchers to support the discoveries and innovations that improve our health and strengthen our health care system.

\section{Banting Postdoctoral Fellowships}

Subjects: Health research, natural sciences and/or engineering, social sciences and/or humanities.

Eligibility: Open to Canadian citizen, permanent resident of Canada, foreign citizens.

Level of Study: Postdoctorate

Type: Award

Value: $\$ 70,000$ per year (taxable)

Length of Study: 2 years
Country of Study: Canada

No. of awards offered: 70 fellowships

Closing Date: End of April

Additional Information: For more details, visit website http://banting

fellowships-bourses.gc.ca/en/app-dem_guide.html.

CIHR Canadian Graduate Scholarships Doctoral Awards

Purpose: To provide special recognition and support to students who are pursuing a doctoral degree in a health-related field in Canada. Eligibility: Candidates are expected to have an exceptionally high potential for future research achievement and productivity. Complete eligibility criteria are available on the CIHR website.

Level of Study: Doctorate, Postgraduate

Type: Award

Value: Canadian $\$ 17,500-35,000$

Length of Study: Maximum of 3 years

Frequency: Annual

Study Establishment: A Canadian Institution

Country of Study: Canada

Application Procedure: Applicants must complete an application form in accordance with programme guidelines, available on the website.

Closing Date: September 26th

Funding: Government

No. of awards given last year: 875

Additional Information: This funding program will be administered through the CIHR Doctoral Award competition, with the top candidates meeting eligibility criteria below receiving a CGS award. Please check the website for further details.

\section{CIHR Doctoral Research Awards}

Subjects: General medical sciences and health sciences.

Purpose: To provide recognition and funding to students early in their academic research career, providing them with an opportunity to gain research experience. To provide a reliable supply of highly skilled and qualified researchers.

Eligibility: Open to Canadian citizens and permanent residents of Canada at the time of application, who are engaged in full-time research training in a graduate school. Please check the website for further details.

Level of Study: Doctorate, Graduate

Type: Award

Value: Canadian $\$ 30,000$ per year plus a $\$ 5,000$ research allowance per year

Length of Study: Maximum of 3 years

Frequency: Annual

Study Establishment: Universities or research institutions

Country of Study: Canada and abroad

No. of awards offered: 400

Application Procedure: Applicants must complete an application form in accordance with programme guidelines, available on the CIHR website.

Closing Date: October 1st

Funding: Government

Contributor: CIHR

No. of awards given last year: 389

No. of applicants last year: 930

Additional Information: Please check at www.cihr-irsc.gc.ca/e/

47149.html for the complete programme description.

\section{CIHR Fellowships Program}

Subjects: Applicants must hold, or be completing, a PhD, health professional degree or equivalent. The health professional degree must be in a regulated health profession such as medicine, dentistry, pharmacy, optometry, veterinary medicine, chiropractic, nursing or rehabilitative science which requires at least a Bachelor's degree to be eligible for licensure in Canada.

Purpose: To provide support for highly qualified candidates at the post $\mathrm{PhD}$ or post health professional degree stages to add to their experience by engaging in health research either in Canada or abroad.

Eligibility: Candidates must hold or be completing a $\mathrm{PhD}$ or health professional degree. Candidates with more than 3 years of post-PhD training by the competition deadline are not eligible to apply.

Candidates may not hold more than 3 years of federal to undertake 
post PhD studies. Please consult CIHR's website for full eligibility requirements. www.cihr-irsc.ge.cale/22340.html.

Level of Study: Postgraduate, Professional development, Research, Postdoctorate, Doctorate, Graduate

Type: Fellowship

Value: The annual stipend level for those with a PhD degree (or equivalent) is $\$ 40,000$ per year. The following stipend levels apply to health professionals who hold licensure (full or educational) in Canada at the time of taking up the award. The stipend level is dependent upon the number of years of research or clinical training completed since obtaining the health professional degree. Upon completion of 2 years of postgraduate research training, the awardees may be eligible to receive a stipend increase to the higher level. $\$ 40,000$ for less than 2 years of research or clinical training experience; $\$ 50,000$ for 2 or more years of research or clinical training experience; $\$ 21,000$ per year as a stipend for health professionals who do not hold licensure in Canada (i.e., equivalent to a Doctoral Research Award). Upon completion of 2 years of postgraduate research training the stipend may increase to $\$ 40,000$ per year. For awards held outside Canada, $\$ 5,000$ is added to the annual stipend. Stipends are valued in Canadian dollars and are taxable

Length of Study: 5 years maximum for health professionals intending to proceed to a PhD degree, 4 years maximum for health professionals who do not intend to proceed to a PhD degree, 3 years maximum for those with a $\mathrm{PhD}$ degree or a $\mathrm{PhD}$ and health professional degree

Frequency: Annual

Study Establishment: Universities or research institutions

Country of Study: Any country

No. of awards offered: 170

Application Procedure: Applicants must submit a training module, a curriculum vitae module for both the candidate and the supervisor(s), official transcripts of the candidate's graduate and/or professional training including proof of any degrees completed, proof of Canadian licensure, three assessments from persons under whom the candidate has studied and a letter of support from the proposed supervisor of foreign candidates and proof of residency/citizenship for Canadians wishing to hold their award outside of Canada.

Closing Date: February 1st and October 1st

Funding: Government

No. of awards given last year: 139

No. of applicants last year: 1,074

Additional Information: Please check at www.cihr-irsc.gc.ca/e/

47191.html for the full programme description.

\section{CIHR Gold Leaf Prizes}

Subjects: Health research.

Eligibility: Open to Canadian citizen, permanent resident of Canada, foreign citizens.

Type: Grant

Value: $\$ 100,000$

Length of Study: 2 years

Frequency: Every 2 years

Country of Study: Canada

Additional Information: For more details, please visit the Contact

Centre: support@cihr-irsc.gc.ca.

\section{CIHR MD/PhD Studentships}

Subjects: General medical sciences.

Purpose: To promote promising students embarking on a combined $\mathrm{MD}$ or PhD programme at approved Canadian Universities.

Eligibility: Candidates for this Studentship Award must be enroled in a combined $\mathrm{MD} / \mathrm{PhD}$ programme at one of the approved Canadian institutions. Research supervisors should normally be holders of operating grants or salary funding obtained through a CIHR peer review process.

Level of Study: Research, Doctorate, Graduate

Type: Grant

Value: A stipend of Canadian $\$ 21,000$ per year plus a yearly research allowance of $\$ 1,000$ is provided

Length of Study: Maximum of 3 years

Frequency: Annual

Study Establishment: The universities of British Columbia, Calgary, Manitoba, McGill, Memorial, Montreal, Toronto, Western Ontario, Alberta
Country of Study: Canada

No. of awards offered: 14

Application Procedure: Applicants must be nominated by the director of the MD/PhD programme at each institution.

Closing Date: July

Funding: Government

Contributor: CIHR

Additional Information: For further information please contact the $\mathrm{CIHR}$ or refer to the website.

\section{Foundation Grant Program}

Subjects: Health research, natural sciences and/or engineering, social sciences and/or humanities.

Purpose: Foundation grants are designed to support research leaders at any career stage to build and conduct programmes of health research across CIHR's mandate.

Eligibility: Open to Canadian citizen, permanent resident of Canada, foreign citizens.

Type: Grant

Value: Proportionate to the requirements of the research proposed and vary depending on the research field, research approach, and scope of programme activities

Length of Study: 5 to 7 years

Country of Study: Canada

Application Procedure: Please refer website www.cihr-irsc.gc.ca for application procedures.

Closing Date: March 14th

Additional Information: For more details, please visit the Contact Centre: support@cihr-irsc.gc.ca.

\section{Project Grant Program}

Subjects: Health research, natural sciences and/or engineering, social sciences and/or humanities.

Purpose: Project grants are designed to support researchers at any career stage to build and conduct health-related research and knowledge translation projects across CIHR's mandate.

Eligibility: Open to Canadian citizen, permanent resident of Canada, foreign citizens.

Type: Grant

Country of Study: Canada

Closing Date: May 15th

Additional Information: For more details, please contact the Contact Centre: support@cihr-irsc.gc.ca.

\section{Vanier Canada Graduate Scholarships}

Subjects: Health research, natural sciences and/or engineering, social sciences and/or humanities.

Purpose: To strengthen Canada's ability to attract and retain worldclass doctoral students and establish Canada as a global centre of excellence in research and higher learning.

Eligibility: Open to Canadian citizen, permanent resident of Canada, foreign citizens.

Level of Study: Doctorate

Type: Award

Value: $\$ 50,000$ per year

Length of Study: 3 years

Country of Study: Canada

No. of awards offered: 167 scholarships are awarded annually

Closing Date: November

\section{CANADIAN LIBRARY ASSOCIATION (CLA)}

1150 Morrison Drive, Suite 400, Ottawa, ON K2H 8S9, Canada Tel: (1) 6132329625

Fax: (1) 6135639895

Email: info@cla.ca

Website: www.cla.ca

Contact: Valoree McKay, Executive Director

The Canadian Library Association works to maintain a tradition of commitment to excellence in library education and to advance continuing research in the field of library and information science. 


\section{CLA Dafoe Scholarship}

Subjects: Library and information studies.

Purpose: Awarded to a student entering a school offering an accredited masters degree in library and information studies for academic achievement, leadership potential, and demonstrated interest in the profession.

Eligibility: Open to Canadian citizens and landed immigrants, commencing studies for their first professional library degree at an ALA-accredited institution.

Level of Study: Postgraduate

Type: Scholarship

Value: Canadian $\$ 5,000$

Length of Study: 1 year

Frequency: Annual

Study Establishment: An accredited library school

Country of Study: United States of America or Canada

No. of awards offered: 1

Application Procedure: Applicants must complete an application form. Applicants must submit transcripts, references and proof of admission to a library school.

Closing Date: May 1st

Funding: Commercial

No. of awards given last year: 1

Additional Information: Please check at http://www.cla.ca/AM/ Template.cfm?Section $=$ Scholarships $\&$ Template $=/ \mathrm{CM} /$ ContentDisplay.cfm\&ContentID $=2522$ for further details.

\section{CLA H.W. Wilson Scholarship}

Subjects: Library and information studies.

Purpose: To support students who wish to pursue higher studies in library and information studies.

Eligibility: Open to candidates who are commencing studies for their first professional library degree at an ALA-accredited institution.

Should have Canadian citizenship or hold a landed immigrant status.

Level of Study: Postgraduate

Type: Scholarship

Value: Canadian $\$ 2,000$

Length of Study: 1 year

Frequency: Annual

Country of Study: Canada

Application Procedure: Applicants are required to complete CLA

Scholarship application forms and supply transcripts, reference and proof of admission to a library school. Scholarship applications are reviewed by a committee of members of the CLA.

Closing Date: May 1st

Funding: Foundation

No. of awards given last year: 1

Additional Information: Please check at www.cla.ca/AM/Template. $\mathrm{cfm}$ ?Section $=$ Scholarships $\&$ Template $=/ \mathrm{CM} /$ ContentDisplay . cfm\&ContentID $=2516$ for further details.

\section{CLA Library Research and Development Grants}

Subjects: Library and information sciences.

Purpose: To support members of the Canadian Library Association for theoretical and applied research in the related fields. To encourage and support research undertaken by practitionares in the field of library and information services. To promote research in the field of library and information services by and/or about Canadians.

Eligibility: Open to personal members of the Canadian Library Association.

Level of Study: Postgraduate

Type: Grant

Value: Canadian $\$ 1,000$

Frequency: Annual

Country of Study: Canada

No. of awards offered: 1 or more

Application Procedure: Applicants must submit grant applications via emails and MS word document in either French or English containing contact details, description of the research project, duration of the project, detailed assessment of costs and statement of other grants/awards received. Proposals should be submitted via email.

Closing Date: February (check with website)

Additional Information: Please check at www.cla.ca/AM/Template. $\mathrm{cfm}$ ?Section $=$ Grants\&Template $=/ \mathrm{CM} / \mathrm{HTMLDisplay} . \mathrm{cfm} \&$ Conten$\mathrm{tID}=12526$ for further details.
For further information contact:

c/o Canadian Library Association, 1150 Morrison Drive, Suite 400, Ottawa, ON, K2H $8 \mathrm{~S} 9$

Tel: 6132329625 ext 322

Fax: 6135639895

Email: info@cla.ca

Contact: CLA Research \& Development Grant

\section{CANADIAN LIVER FOUNDATION}

\author{
Suite 801, 3100 Steeles Avenue East, Markham, \\ ON L3R 8T3, Canada \\ Tel: (1) 4164913353 \\ Fax: (1) 9057521540 \\ Email: clf@liver.ca \\ Website: www.liver.ca
}

The Canadian Liver Foundation provides support for research and education into the causes, diagnosis, prevention and treatment of diseases of the liver.

\section{Canadian Liver Foundation Graduate Studentships}

Subjects: Hepatology, chemistry and biochemistry.

Purpose: To enable academically superior students to undertake fulltime studies in a Canadian university in a discipline relevant to the objectives of the Foundation.

Eligibility: Candidates must be accepted into a full-time university graduate science programme in a medically related discipline related to a Master's or doctoral degree, and hold a record of superior academic performance in studies relevant to the proposed training. Level of Study: Doctorate, Graduate, Postgraduate

Type: Studentship

Value: Canadian $\$ 20,000$ per year. Payment of the award will be in the form of equal quarterly installments, the first on or about September 1

Length of Study: 2 years

Country of Study: Canada

No. of awards offered: Varies, Dependent on availability of funds Application Procedure: Applicants must submit application forms along with supporting documents. Application forms can be obtained from the applicant's institution or from the Canadian Liver Foundation website.

Closing Date: March 31st

Funding: Private

Additional Information: A student supported by the Foundation must not hold a current stipend award from another granting agency. Please check at www.grad.ubc.ca/awards/canadian-liver-foundationgraduate-studentships for further details.

\section{Canadian Liver Foundation Operating Grant}

Subjects: Hepatology.

Purpose: To support research projects directed towards a defined objective.

Eligibility: Open to hepatobiliary research investigators who hold an academic appointment in a Canadian university or affiliated institution. Level of Study: Research

Type: Grant

Value: Up to Canadian $\$ 60,000$ per year

Length of Study: 2 years

Country of Study: Canada

No. of awards offered: 6

Application Procedure: Applicants must submit application forms along with supporting documentation. Application forms can be obtained from the applicant's institution or from the Canadian Liver Foundation website.

Closing Date: March 31st

Funding: Private

Additional Information: Three operating grants may be awarded to researchers in Canada whose projects are related to hepatobiliary research; two operating grants may be awarded to researchers in the province of Alberta whose projects are related to hepatobiliary research; and one operating grant may be awarded to a researcher in Canada whose research project is related to liver cancer. Please check at www.liver.ca/liver-education-liver-research/research/grantprograms/type-grants.aspx for further details. 


\section{THE CANADIAN NATIONAL INSTITUTE FOR THE BLIND (CNIB)}

1929 Bayview Avenue, East York, Toronto, ON M4G 0A1, Canada

Tel: (1) 1800563 2642, 14164862500

Fax: (1) 4164807700

Email: info@cnib.ca

Website: www.cnib.ca

Contact: Mr John M Rafferty, President and CEO

CNIB is a nationwide, community-based, registered charity committed to public education, research and the vision health of all Canadians. CNIB provides the services and support necessary to enjoy a good quality of life while living with vision loss. Founded in 1918, CNIB reaches out to communities across the country, offering access to rehabilitation training, innovative consumer products and peer support programs as well as one of the world's largest libraries for people with a print disability. CNIB supports research to advance knowledge in the field of vision health. Our research program funds projects that focus on ways to cure, treat and prevent eye disease, and improve the quality of life for people with vision loss.

\section{CNIB Winston Gordon Award}

Subjects: Product Development assistive technology for the blind or are partially sighted.

Purpose: The award is presented to an individual or group who has made significant technological advances benefiting people with vision loss.

Eligibility: The significant advances in, or application of, technology must have occurred within 10 years of nomination. The device or application must have a documented benefit to people who are blind or visually impaired. The award may be presented to an individual, group, or organization, including corporations and academic institutions.

Type: Award

Value: The award consists of a cash prize of up to Canadian $\$ 10,000$ Country of Study: Any country

No. of awards offered: 1

Application Procedure: To submit a nomination, please write a letter to the Winston Gordon Committee nominating the individual or group for its products or services, and explaining how the nominee meets or surpasses the eligibility criteria and matches the goals of the award.

Closing Date: January 16th

Funding: Private

\section{For further information contact:}

Winston Gordon Award Committee, CNIB, 1929 Bayview Avenue, Toronto, ON, M4G 3E8, Canada

Fax: (1) 4164807000

Email: shampa.bose@cnib.ca

Contact: Shampa Bose, Grants and Awards Coordinator

\section{The E. (Ben) \& Mary Hochhausen Access Technology Research Award}

Subjects: Research awards may be applied to: research projects, study at centers of excellence in Archnology, fellowships, development of prototypes and development costs of bringing important new products to market.

Purpose: To encourage research in the field of access technology for people living with vision loss.

Eligibility: Applications are accepted from any country in the world. Level of Study: Research

Type: Research award

Value: Up to Canadian $\$ 10,000$

Country of Study: International

No. of awards offered: 1

Application Procedure: Please check at www.cnib.ca/en/research/

funding/hochhausen/ for more information.

Closing Date: September 30th

Funding: Private

No. of awards given last year: 1
For further information contact:

CNIB, 1929 Bayview Avenue, Toronto, ON, M4G 3E8, Canada

Tel: (1) 4164862500 ext 7622

Fax: (1) 4164807000

Email: shampa.bose@cnib.ca

Contact: Trustees, The Hochhausen Fund

\section{Gretzky Scholarship Foundation for the Blind Youth of \\ Canada}

Subjects: The Gretzky family continue a tradition of assisting the blind youth of Canada to pursue their academic and lifelong dreams. Purpose: To provide scholarships to eligible blind and visually impaired students planning to study at the post-secondary level. Eligibility: All applicants must be blind or visually impaired, a graduate from secondary school entering their first year of postsecondary education, and a Canadian citizen.

Level of Study: Post secondary for blind or visually impaired students Type: Scholarship

Value: Canadian $\$ 3,000-5,000$ each

Frequency: Annual

Country of Study: Canada

No. of awards offered: 20

Application Procedure: All documents requested in the application form must be included with your application. Please send application and documents to Kim Kohler.

Closing Date: May 31st

Funding: Private

No. of awards given last year: 23

For further information contact:

955256 Canning Road, R.R. 2, Paris, Ontario, N3L 3E2, Canada

Tel: (1) 5194588665

Fax: (1) 5194588609

Email: Kim.Kohler@cnib.ca

Contact: Kim Kohler, Walter and Wayne Gretzky Scholarship Foundation

\section{Ross Purse Doctoral Fellowship}

Subjects: The fellowship will be awarded for research in social sciences, engineering and other fields of study that are immediately relevant to the field of vision loss.

Purpose: To encourage and support theoretical and practical

research and studies at the postgraduate or doctoral level in the field of vision loss in Canada.

Eligibility: Applications will be considered from persons studying at a Canadian University or college, or at a foreign University, where a commitment to work in the field of vision loss in Canada for at least 2 years can be demonstrated.

Level of Study: Doctorate, Postgraduate

Type: Fellowship

Value: Up to Canadian $\$ 12,500$ to be paid in three equal installments

Length of Study: 2 years

Frequency: Annual

Country of Study: Any country

No. of awards offered: 1

Application Procedure: Please send completed applications to

Research Coordinator.

Closing Date: April 2nd

Funding: Private

For further information contact:

CNIB, 1929 Bayview Avenue, Toronto, ON, M4G 3E8, Canada

Tel: (1) 4164862500 ext. 7622

Fax: (1) 4164807000

Email: shampa.bose@cnib.ca

Contact: Shampa Bose, Research Coordinator, Grants, Awards \&

Scholarship Program

\section{Tuck MacPhee Award}

Subjects: Ophthalmology and optometry.

Purpose: To provide a 1-year grant in support of research in macular degeneration.

Eligibility: Open to all researchers, however applicants must be residents of Canada and research must be conducted primarily in 
Canada. Trainees (residents, fellows, post graduate students) are not eligible to apply.

Level of Study: Research

Type: Grant

Value: Up to Canadian $\$ 35,000$

Length of Study: 1 year

Frequency: Annual

Country of Study: Canada

No. of awards offered: Varies

Application Procedure: Applicants must apply online no later than January 15th of each year. The application will be reviewed by a multi-disciplinary review committee, and decisions will be finalized by April 1st.

Closing Date: January 15th

Funding: Private

Additional Information: For any inquiries please contact Shampa Bose, Executive Assistant and Research Coordinator. Please check this website in May/June for a further update.

\section{CANADIAN NURSES FOUNDATION (CNF)}

\author{
50 Driveway, Ottawa, ON, K2P 1E2, Canada \\ Tel: (1) $6136800879 ; 8442040124$ \\ Fax: (1) 6132373520 \\ Email: info@cnf-fiic.ca \\ Website: www.cnf-fiic.ca \\ Contact: CNF Scholarship Co-ordinator
}

To advance nursing knowledge and improve healthcare by providing research grants, awards, and scholarships to Canadian nurses and nursing students. We raise funds for our activities through diverse partnerships with responsible organizations and individuals who share our goals.

\section{CNF Scholarships and Fellowships}

Subjects: All nursing specialities. Several awards are identified for neurosurgery, oncology, community health nursing, epidemiology, gerontology, child or family healthcare, nursing administration, occupational health, dialysis nursing, home care nursing and aplastic anaemia.

Purpose: To assist Canadian nurses pursuing further education and research.

Eligibility: Open to Canadian citizens or permanent residents. Level of Study: Graduate, Doctorate, Postgraduate, Predoctorate, Professional development, Research, Baccalaureate

Type: Scholarships, fellowships, bursaries

Value: Canadian $\$ 1,000-6,000$

Length of Study: 1 year

Frequency: Annual

Country of Study: Canada

No. of awards offered: Varies

Application Procedure: Applicants must visit the website for the application forms, criteria and requirements at www.cnf-fiic.ca. Closing Date: March 31st (check with website)

Funding: Private

Contributor: Corporations, other foundations, individuals

No. of awards given last year: 61

No. of applicants last year: 277

Additional Information: Recipients must provide a progress report, and a final report at the end of the their academic year. Please check at http://cnf-fiic.ca/what-we-do/scholarships-and-bursaries/ scholarship-types/ for further details.

\section{CANADIAN SOCIETY FOR CHEMICAL TECHNOLOGY}

Chemical Institute of Canada, 222 Queen street, Suite 400, Ottawa, ON, K1P 5V9, Canada

Tel: (1) 6132326252 ext 223, 18885422242

Fax: (1) 6132325862

Email: awards@cheminst.ca, gthirlwall@cheminst.ca

Website: www.cheminst.ca/about/cic/csct

Contact: Gale Thirlwall, Awards Manager
The Canadian Society for Chemical Technology is the national technical association of chemical and biochemical technicians and technologists with members across Canada who work in industry, government or academia. The purpose of the Society is the advancement of chemical technology, the maintenance and improvement of practitioners and educators and the continual evaluation of chemical technology in Canada. The Society hopes to maintain a dialogue with educators, government and industry, to assist in the technology content of the education process of technologists, to attract qualified people into the professions and the Society, to develop and maintain high standards and enhance the usefulness of chemical technology to both the industry and the public.

\section{CIC Fellowships}

Subjects: Chemistry, chemical engineering, chemical technology. Purpose: A senior class of membership that recognizes the merits of $\mathrm{CIC}$ members who have made outstanding contributions.

Eligibility: Member of $\mathrm{CIC}$, in good standing for at least 10 years. Candidates should have made contribution to the discipline in 4 years or one outstanding contribution in one area in particular. Details at www.chemist.ca/fellowship.

Frequency: Annual

No. of awards offered: Multiple

Application Procedure: Nomination form, Letters of support must be from a member of $\mathrm{CIC}$ for a minimum of 10 years.

Closing Date: December 1st

Additional Information: Please check at www.cheminst.ca/awards/ csct-award for further details.

\section{Norman and Marion Bright Memorial Award}

Subjects: Chemical technology.

Purpose: To reward an individual who has made an outstanding contribution in Canada to the furtherance of chemical technology. Eligibility: Open to chemical sciences technologists or persons from outside the field who have made significant or noteworthy contribution to its advancement.

Type: Award

Value: A framed certificate, together with an honorarium of $\$ 500$

Frequency: Annual

Country of Study: Canada

Application Procedure: Applicants must complete a nomination form and submit alongwith it (1) a curriculum vitae, (2) a bio and citation, and (3) letters of support.

Closing Date: December 1st

Funding: Trusts

Contributor: $\mathrm{CIC}$ Chemical Education Fund

Additional Information: Award winners are welcome to submit papers at either the Canadian Society for Chemistry or Canadian Society for Chemical Engineering.

\section{CANADIAN SOCIETY FOR CHEMISTRY (CSC)}

222 Queen street, Suite 400, Ottawa, ON KIP 5V9, Canada

Tel: (1) 6132326252 ext 223

Fax: (1) 6132325862

Email: awards@cheminst.ca, gthirlwall@cheminst.ca Website: www.cheminst.ca/about/cic/csc Contact: Gale Thirlwall, Awards Manager

The Canadian Society for Chemistry (CSC), one of three constituent societies of The Chemical Institute of Canada, is the national scientific and educational society of chemists. The purpose of the CSC is to promote the practice and application of chemistry in Canada.

\footnotetext{
Award for Research Excellence in Materials Chemistry Subjects: Chemistry.

Purpose: To recognize outstanding contribution to materials chemistry while working in Canada.

Eligibility: Candidates must be with 15 years of their first independent appointment.

Level of Study: Research

Type: Fellowship
} 
Value: Up to $\$ 1,000$ travel costs for award tour, framed scroll Frequency: Annual

Application Procedure: Please check website for details. Closing Date: July 2nd (check with website)

Funding: Private

Additional Information: Please check at www.cheminst.ca/awards/ csc-awards for further details.

\section{For further information contact:}

Canadian Society for Chemistry (CSC), 222 Queen Street, Suite 400, Ottawa, ON K1P 5V9, Canada

Tel: (1) 6132326252 ext 223

Fax: (1) 6132325862

Email: awards@cheminst.ca, gthirlwall@cheminst.ca

Website: www.cheminst.ca/awards/csc-awards

Contact: Gale Thirlwall Awards Manager

\section{CCUCC Chemistry Doctoral Award}

Subjects: Chemistry.

Purpose: To recognize outstanding achievement and potential in research by a graduate student.

Eligibility: Open to graduate student whose $\mathrm{PhD}$ thesis in chemistry was formally accepted by a Canadian university in the 12-month period preceding the nomination deadline.

Level of Study: Postgraduate

Type: Award

Value: A framed scroll, $\$ 2,000$ and 1-year membership to the society Frequency: Annual

Application Procedure: Applicants must submit one original and four copies of the nomination package to the awards manager. Applicants must visit website for more details on this.

Closing Date: September 15th (check with website)

Funding: Private

Contributor: Canadian Council of University Chemistry Chairs

No. of awards given last year: 1

Additional Information: Please check at www.cheminst.ca/awards/ csc-awards/ccucc-chemistry-doctoral-award for further details.

\section{CANADIAN SPACE AGENCY}

John H. Chapman Space Centre, 6767 Route de l'Aéroport Saint-Hubert, Quebec, J3Y 8Y9, Canada

Tel: (1) 4509264800

Fax: (1) 4509264352

Email: dave.kendall@space.gc.ca

Website: www.asc-csa.gc.ca

Contact: David Kendall, Director General, Space Science

The Canadian Space Agency (CSA) was established in 1989 by the Canadian Space Agency Act. The agency operates like a government department.

\section{Canadian Space Agency Supplements Postgraduate Scholarships \\ Subjects: Space science.}

Purpose: To foster advanced studies in space science by offering a supplement to the regular National Science and Engineering

Research Council (NSERC) postgraduate scholarships.

Eligibility: Open to graduate and permanent resident and citizen of Canada engaged in Masters or Doctoral studies in the natural sciences or engineering, or intend to pursue such studies in the following year, is successful in obtaining a NSERC postgraduate scholarship (PGS) or a Canada graduate scholarships (CGS-Master's).

Level of Study: Postgraduate

Type: Scholarship

Value: $\$ 7,500$ per year for one year for masters students and up to two years for doctoral students

Length of Study: 2 years

Frequency: Annual

Country of Study: Canada

No. of awards offered: 6

Application Procedure: Candidates should apply to the NSERC postgraduate scholarship or Canada graduate scholarship programs by completing Form 200. After reviewing the forms, notification of award will be sent to the selected applicants.
Closing Date: May 1st (check with website)

Funding: Government

Contributor: National Science and Engineering Research Council Additional Information: A candidate who is in receipt of a scholarship from federal sources other than NSERC will not be eligible for this supplement. Please check at www.asc-csa.gc.ca/eng/resources/gc/ research.asp\#recipients-2 for further details.

For further information contact:

Email: sc-gc.centre.expertise@asc-csa.gc.ca

\section{CANADIAN THORACIC SOCIETY (CTS)}

The Lung Association, National Office, 1750 Courtwood Cres, Suite 300, Ottawa, ON, K2C 2B5, Canada

Tel: (1) 6135696411 ext. 229

Fax: (1) 6135698860

Email: ctsinfo@lung.ca

Website: www.lung.ca/cts

Contact: Janet Sutherland, Director

The Canadian Thoracic Society (CTS) is the medical section of the Canadian Lung Association. It advises the Association on scientific matters and programmes including policies regarding support for research and professional education. The CTS provides a forum whereby medical practitioners and investigators may join in the study of thoracic diseases and other medical fields that may come within the scope of the Lung Association. The CTS's objectives are to maintain the highest professional and scientific standards in all aspects of respiratory diseases, to collect, interpret and distribute scientific information, to encourage epidemiological, clinical and other scientific studies in the prevention, diagnosis and treatment of respiratory diseases and to stimulate and support undergraduate, postgraduate, and continuing medical education in respiratory diseases.

\section{CTS Research Fellowship and Studentship Award}

Subjects: Pulmonary disease.

Purpose: To support research training in pulmonary disease. Eligibility: Applicants must be Canadian citizens or permanent residents of Canada. Candidates for the award must have obtained an $\mathrm{MD}$ or $\mathrm{PhD}$ degree or the equivalent and must not hold a universitylevel academic position. Those expected to receive a PhD degree within the following year are eligible to apply but may not begin the fellowship until the $\mathrm{PhD}$ requirements have been completed. CLA Fellows may not work on projects that have not been approved by the appropriate institutional ethics committees.

Level of Study: Postgraduate

Type: Fellowship

Value: Studentship is valued at Canadian $\$ 22,000$ per year for a maximum of 2 years in which CRRN will contribute $\$ 11,000$ annually and the Host Institution or a partner agency is required to contribute the remaining $\$ 11,000$ annually for the length of term for the award. The Fellowship award is valued at $\$ 50,000$ per year for a maximum of 2 years in which CRRN will contribute $\$ 30,000$ annually and the Host Institution or a partner agency is required to contribute the remaining $\$ 20,000$ annually for the length of term for the award. Stipends for candidates with a medical degree will be equivalent to those with a $\mathrm{PhD}$ Length of Study: 1 year, with a possibility of renewal for a further year Country of Study: Canada

No. of awards offered: 1-2 awards

Application Procedure: Applicants must submit applications on CIHR forms.

Closing Date: January 31st

Funding: Commercial, government

Contributor: The Canadian Lung Association, the Canadian Institutes of Health Research, Industry Partners, e.g. Glaxo Smithkline Inc. Merck Frosst Can, Bayer Inc, Boehringer Ingelheim and Astrazeneca No. of applicants last year: $30-50$ applicants

Additional Information: Recipients are selected based on priority ratings provided by the $\mathrm{CIHR}$ and are subject to the approval of the Canadian Thoracic Society and the Canadian Lung Association (CLA) Board of Directors. Applicants are screened to ensure proposed research areas are appropriate to the goals of the CLA. Fellowships are awarded in each case for research training in a specific institution, and may not be transferred without the explicit approval of both institutions involved. 
For further information contact:

Canadian Thoracic Society, 1750 Courtwood Cres. Suite 300, Ottawa, ON, K2C 285, Canada

Website: www.cihr.ca

\section{CANADIAN WATER RESOURCES ASSOCIATION (CWRA)}

CWRA Membership Services, 9 Corvus Court, Ottawa, ON, K2E 7Z4, Canada

Tel: (1) 6132379363

Fax: (1) 6135945190

Email: services@aic.ca

Website: www.cwra.org

The Canadian Water Resources Association (CWRA) is a national organization of individuals and organizations interested in the management of Canada's water resources. The membership is composed of private and public sector water resource professionals including managers, administrators, scientists, academics, students and users. CWRA has branch organizations in 9 provinces and members throughout Canada and beyond.

\section{CWRA Dillon Consulting Scholarship/Ken Thomson \\ Scholarship}

Subjects: Applied, natural or social science aspects of water resources.

Purpose: These scholarship are available to graduate students whose programs of study focus upon applied, natural, or social science aspects of water resources.

Eligibility: Open to Canadian citizens or landed immigrants attending a Canadian university or college who are enrolled in full-time graduate studies in any discipline.

Level of Study: Postgraduate

Type: Scholarship

Value: Canadian $\$ 2,000$ (1) $\$ 5,000$ (1) $\$ 1,500$ (3)

Frequency: Annual

Country of Study: Canada

No. of awards offered: 5

Application Procedure: Candidates must submit a 500 word statement that outlines the applicant's research project and its relevance to sustainable water resources, transcripts, reference letters, a statement from the programme chairman or director endorsing the application form that programme along with the completed application form. Applications are available from the award office of any university.

Closing Date: February 13th (check with website)

Funding: Commercial, foundation

Contributor: Dillon Consulting Scholarship is provided by Dillon Consulting Ltd. on an annual basis. The Ken Thomson Scholarship is awarded from a special fund set up in his honour. The other 3 awards are from the general funds of the Canadian Water Resources. Association

No. of awards given last year: 5

No. of applicants last year: 29

Additional Information: All candidates will receive a 1-year membership in the CWRA. Please check at www.cwra.org/en/about/ scholarships for further details.

\section{THE CANCER COUNCIL N.S.W.}

153 Dowling Street, Woolloomooloo NSW 2011, Kings Cross, PO Box 572, NSW 1340, Australia

Tel: (61) 0293341900

Fax: (61) 0293269328

Email: rong@nswcc.org.au

Website: www.cancercouncil.com.au

The Cancer Council NSW is one of the leading cancer charity organizations in New South Wales. Its mission is to defeat cancer and is working to build a cancer-smart community. In building a cancersmart community, the Council undertakes high-quality research and is an advocate on cancer issues, providing information and services to the public and raising funds for cancer programmes.
The Cancer Council NSW Research Project Grants

Subjects: All aspects of cancer that elucidate its origin, cause and control at a fundamental and applied level. Grants are open to all research disciplines relevant to cancer including behavioural, biomedical, clinical, epidemiological, psychosocial and health services. Purpose: To provide flexible support for cancer researchers. Eligibility: Open to researchers working in NSW institutions. Level of Study: Unrestricted

Type: Project grant

Value: Generally a maximum of Australian $\$ 150,000$ per year Length of Study: Up to 3 years

Frequency: Annual

Study Establishment: An approved institution in New South Wales Country of Study: Australia

No. of awards offered: Varies

Application Procedure: Applicants must complete an application form, available on request or from the website. Applications are submitted through the researcher's institution to NHMRC. Applicants must also complete a supplementary question form and a consumer review form.

Closing Date: March 18th (check with website)

Funding: Private

Contributor: Community fund-raising

No. of applicants last year: 106

Additional Information: Further information is available from either the NHMRC Liaison Officer (National Cancer Research Grants Secretariat) or from Cancer Council NSW. Please check at www.cancercouncil.com.au/1221/research/research-funding-andgovernance/funding-opportunities/new-grants/ for further details.

For further information contact:

NHMRC, GPO Box 9848, Canberra, ACT, 2601, Australia

Tel: (61) 0396355028

Email: CancerCouncilGrants@cancervic.org.au

Contact: Miss Josie Italia

\section{THE CANCER COUNCIL SOUTH AUSTRALIA}

202 Greenhill Road, Eastwood, SA, 5063, Australia

Tel: (61) 82914111

Fax: (61) 82914122

Email: cc@cancersa.org.au

Website: www.cancersa.org.au

The Cancer Council South Australia is a community-based charity independent of government control that has developed since 1928 with the support of South Australians. The Foundation's mission is to pursue the eradication of cancer through research and education on the prevention and early detection of cancer, thus enhancing the quality of life for people living with cancer.

\section{PhD Scholarships}

Subjects: Cancer research.

Purpose: To support cancer researchers in South Australia through the provision of research and senior research fellowships.

Eligibility: Applicant must be a student judged to be the best applicant from University of Adelaide, Flinders University or University of South Australia, who is commencing PhD studies. The applicant must not be currently enroled in a PhD, must be eligible for the Research Training Scheme and must not have been previously enroled for a Research Degree. Students are eligible to apply for the scholarship if they are enroled in the Faculty or Division of Health Sciences at their institution and if their PhD topic is in an area of cancer research.

Level of Study: Postgraduate

Type: Scholarship

Value: Equivalent to the value of the stipend for an APA award Length of Study: 3 years

Frequency: Annual

Country of Study: Australia

No. of awards offered: 1

Application Procedure: Applicants must contact the relevant Scholarships Offices of The University of Adelaide, University of South 
Australia and Flinders University for further information and closing dates.

Closing Date: See the website

For further information contact:

Tel: 0882914297

Email: npolglase@cancersa.org.au

Contact: Nicole Polglase, Executive Assistant Research and Development

\section{Research Project Grants}

Subjects: Any scientific or medical field directly concerned with the cause, diagnosis, prevention and treatment of cancer.

Purpose: To assist postgraduate research workers undertaking research into cancer.

Eligibility: Open to postgraduate research workers who show promise of establishing themselves or to those who have already established themselves in the field of cancer research.

Level of Study: Postdoctorate

Type: Research grant

Value: up to $\$ 100,000$

Length of Study: 1 year

Frequency: Annual

Study Establishment: An appropriate research organization

Country of Study: Australia

No. of awards offered: Approx. 20

Application Procedure: Visit our website for details www.cancersa. org.au.

Closing Date: March 16th (check with website)

Funding: Private

Contributor: South Australian community

No. of awards given last year: 19

No. of applicants last year: 48

\section{CANCER RESEARCH INSTITUTE}

National Headquarters, One Exchange Plaza, 55 Broadway, Suite 1802, New York, NY, 10006 United States of America

Website: www.cancerresearch.org

\section{CRI Irvington Postdoctoral Fellowship Program}

Purpose: To support qualified young scientists at leading universities and research centers around the world who wish to receive training in cancer immunology.

Eligibility: Applicants for the CRI Irvington Postdoctoral Fellowship Program must be working in areas directly related to cancer immunology. An eligible project must fall into the broad field of immunology and must show relevance to solving the cancer problem. Proposals that do not encompass both these areas will not be considered. Check website for complete eligibility.

Type: Fellowship

Value: Fellows receive up to $\$ 175,500$ over 3 years to cover the cost of stipend or salary, insurance, and other research-related expenses, such as travel to conferences and meetings

Frequency: Biannual

Closing Date: April

Additional Information: Please check more information at www.cancerresearch.org/grants-programs/grants-fellowships/ cri-irvington-postdoctoral-fellowships.

\section{THE CANCER RESEARCH SOCIETY, INC.}

625 President-Kennedy Avenue, Suite 402, Montréal, QC, H3A 3S5, Canada

Tel: (1) 5148619227

Fax: (1) 5148619220

Email: grants@src-crs.ca

Website: www.cancerresearchsociety.ca

Contact: Mr François Castonguay, Director

The Cancer Research Society, founded in 1945, is a national organization that devotes its funds exclusively to research on cancer. The Society is committed to funding basic cancer research or seed money for original ideas. The funds are allocated in the form of grants to universities and hospitals across Canada.

Cancer Research Society (Canada) Operating Grants

Subjects: Fundamental research on cancer.

Purpose: To provide support for new or continuing research activities by independent scientists or groups of investigators in the field of cancer in Canada.

Eligibility: Candidates must hold an academic position on the staff of a Canadian university.

Level of Study: Research

Type: Grant

Value: Canadian $\$ 60,000$ yearly, for 1 year to cover the cost of research. No equipment or travel is permitted

Frequency: Annual

Study Establishment: Universities and their affiliated institutions

Country of Study: Canada

No. of awards offered: $30-50$

Application Procedure: Applicants must visit the website for details of application procedures.

Closing Date: February 17th

Funding: Foundation, individuals, private

No. of awards given last year: 47

No. of applicants last year: 205

Additional Information: Due to the contribution of donors and partners, competitions addressing specific areas of cancer research are available. Recent examples include 'Restricted fund' cancer type. Please check at www.crs-src.ca/For_Researchers Operating_Grant for further details.

\section{GRePEC (Research and Prevention Group on \\ Environment-Cancer)}

Subjects: Fundamental research on environment-cancer.

Purpose: To develop research on the links between environment and cancer in Quebec, Canada.

Eligibility: Open to team researchers with academic appointment from Quebec University. This program encourage multidisciplinary and multi-institutional projects.

Level of Study: Research

Type: Grant

Value: $\$ 100,000$ per year. This amount includes benefits available according to the host institution

Frequency: Annual

Study Establishment: Universities and their affiliated institutions

Country of Study: Canada

No. of awards offered: 1

Application Procedure: Applicants must visit the CRS website for details of application procedure.

Closing Date: July 11th (check with website)

Funding: Government, individuals, private

No. of awards given last year: 1

No. of applicants last year: 5

Additional Information: Please check at www.crs-src.ca/page.aspx? pid $=1747$ for further details.

\section{CANCER RESEARCH UK CAMBRIDGE RESEARCH INSTITUTE}

Cancer Research UK Cambridge Institute, University of Cambridge, Li Ka Shing Centre, Robinson Way, Cambridge, CB2 ORE, United Kingdom

Tel: (44) 01223769500

Fax: (44) 01223404208

Email: publicaffairs@cancer.org.uk Website: www.cambridgecancer.org.uk

The Institute aims to link the laboratory to the clinic with a multidisciplinary approach to cancer-focussed research.

\section{Dr Lynn MacFadyen PhD Studentship in Tobacco Control} Policy

Subjects: Cancer research/oncology.

Purpose: To support research relevant to a priority area of tobacco control policy. 
Eligibility: Applications are accepted from UK-based researchers in universities and medical schools.

Level of Study: Doctorate

Type: Studentship

Value: The studentship will provide funding for a competitive stipend for the student, tuition fees and reasonable running costs

Length of Study: 3 years

Frequency: As available

Study Establishment: Cambridge Research Institute

Country of Study: United Kingdom

Application Procedure: Applications must be submitted via our electronic Grants Management System (eGMS). See How to apply for more information and to submit your application via eGMS.

Closing Date: February

Funding: Foundation

Contributor: Cancer Research UK and University of Cambridge

Additional Information: For enquiries related to this funding scheme, please email Chit Selvarajah or call +44 (0) 2034698095 .

\section{Population Research Postdoctoral Fellowship}

Subjects: Cancer research/oncology.

Purpose: The Population Research Postdoctoral Fellowship provides support for outstanding postdoctoral researchers to develop their careers in the field of population science.

Eligibility: Applicants should have completed, or be about to complete, their $\mathrm{PhD}$ and have less than 6 years of postdoctoral research experience at the time of submitting their application. Applications are welcomed from clinical and nonclinical researchers. Please note that clinicians holding a consultant post are not eligible to apply for this fellowship, but can apply for the Clinician Scientist Fellowship. Applicants should be aiming to gain postdoctoral experience, with the ultimate objective of building an independent research group. Candidates of any nationality may apply but must intend to pursue a career in the UK.

Level of Study: Postdoctorate, Doctorate

Type: Fellowship

Value: The Fellowship provides funding for the salary for the Fellow, research expenses and equipment

Length of Study: 3 years

Frequency: As available

Study Establishment: Cambridge Research Institute

Country of Study: United Kingdom

Application Procedure: Applicants are encouraged to contact the office (see contact details below) to discuss their eligibility and suitability of their research proposal in advance of submitting an application. All applications must be made online. Support on preparing your application is available through your regional Research Design Service (RDS).

Closing Date: November

Funding: Foundation

Contributor: Cancer Research UK and University of Cambridge

Additional Information: Please check at www.cancerresearchuk. org/funding-for-researchers/our-funding-schemes/populationresearch-postdoctoral-fellowship for further details.

\section{CANCER RESEARCH UK MANCHESTER INSTITUTE}

The University of Manchester, Wilmslow Road, Manchester, M20 4BX, England

$$
\text { Tel: (44) } 1614463156
$$

Fax: (44) 1614463109

Email: enquiries@cruk.manchester.ac.uk Website: www.cruk.manchester.ac.uk

The CRUK Manchester Institute is a leading cancer research institute within The University of Manchester that is core-funded by CRUK Research spans the whole spectrum of cancer research, from the molecular and cellular basis of cancer, to translational research and the development of therapeutics. It houses 14 diverse research groups.

\section{4-Year Studentship}

Subjects: Molecular and cellular basis of cancer and translational cancer research.

Purpose: To support study towards a PhD.
Eligibility: Open to candidates who have obtained a First or Second Class (Honours) Bachelor of Science Degree. International First or 2.1 degree equivalent in biological science, medicine, or related subject.

Level of Study: Doctorate, Postgraduate, 3 times per year

Type: Studentship

Value: UK£19,000 as stipend per year, university fees and bench fees

Length of Study: 4 years

Frequency: Annual, 3 times per year

Study Establishment: The University of Manchester

Country of Study: United Kingdom

No. of awards offered: Up to 10 per year

Application Procedure: Please visit www.cruk.manchester.ac.uk for details and download application form.

Closing Date: Refer to the website

Funding: Private

Contributor: Cancer Research UK

No. of awards given last year: 5

No. of applicants last year: 343

Additional Information: All positions are advertised on the website. Self-funded students are accepted subject to qualifications and 3-year funding. Please use application form, available at website.

For further information contact:

Cancer Research UK Manchester Institute

Email: pgt@cruk.manchester.ac.uk

Contact: Postgraduate Tutor

\section{CANON COLLINS EDUCATIONAL AND LEGAL ASSISTANCE TRUST}

22 The Ivories, 6 Northampton Street, London, GB, N1 2HY, United Kingdom

Tel: (44) +27 105002303

Email: info@canoncollins.org.uk

Website: http://www.canoncollins.org.uk/

Canon Collins Educational \& Legal Assistance Trust is building a community of change agents across southern Africa who create and use research for social impact.

\section{Graça Machel Trust Scholarships}

Purpose: Canon Collins Educational and Legal Assistance Trust is offering Graça Machel Trust scholarships for Southern Africa's future women leaders.

Eligibility: To apply for a scholarship under this programme you must be, a female, A national of and normally resident in one of the SADC countries: Angola, Botswana, DRC, Lesotho, Madagascar, Malawi, Mauritius, Mozambique, Namibia, South Africa, Swaziland, Tanzania, Zambia, Zimbabwe.

Type: Scholarship

Value: In 2016 most awards will be valued at R65,000 for each year of study at Masters and PhD level. In exceptional cases they may offer up to $\mathrm{R} 100,000$ per year

Length of Study: Funding is awarded for up to a maximum of one year for Honours, two years for Masters and three years for PhD Country of Study: South Africa

Application Procedure: Check website for more details.

Closing Date: July 27 th

Funding: Trusts

\section{CANON COLLINS TRUST}

\author{
22 The Ivories, 6 Northampton Street, \\ London, N1 2HY, England \\ Tel: (44) 02073541462 \\ Fax: (44) 02073594875
}

Email: info@canoncollins.org.uk, victoria@canoncollins.org.uk Website: www.canoncollins.org.uk Contact: Victoria Reed, Scholarships Officer

We believe that southern Africa's development depends on strong leadership in key fields. Our scholars are outstanding academics and professionals who are dedicated to the development of their countries. 
We seek to invest in those who share our commitment to social justice and who can demonstrate their intention to return to their home countries after their study.

\section{Canon Collins Scholarship for Distance Learning Master of Laws (LLM)}

Subjects: Canon Collins Trust invites applications for scholarships for the Master of Laws (LLM) by distance learning of the University of London. These scholarships are made possible by the generosity of University of London International Programmes which shall waive full tuition and examination entry fees for four scholarship recipients.

Eligibility: Applicants for this scholarship must be a national of South Africa, Malawi, Zimbabwe or Zambia, normally resident in one of these four countries.

Frequency: Annual, Scholarships are offered for 1 to 5 years Country of Study: United Kingdom

No. of awards offered: 4

Application Procedure: Check website for more details.

Closing Date: January

Funding: Trusts

\section{Canon Collins Scholarship for Masters Study in the UK}

Subjects: All subjects.

Purpose: We believe that southern Africa's development depends on strong leadership in key fields. We seek to invest in those who share our commitment to social justice and who can demonstrate their intention to return to their home countries after their study.

Eligibility: To apply for a scholarship under this programme you must be a national of, or have refugee status in, one of the following countries: Angola, Botswana, Lesotho, Malawi, Mozambique, Namibia, South Africa, Swaziland, Zambia, Zimbabwe, be normally resident in southern Africa, be in possession of a good first degree (minimum second class, upper division or equivalent) or about to graduate in the year of application, be applying for a full-time 1-year taught master's course at one of the below-named universities, have at least 2 years' work experience in a relevant field.

Level of Study: Postgraduate

Type: Scholarship

Value: Full tuition fees, a monthly stipend, a return economy flight, a settling-in allowance and other support whilst in the UK

Length of Study: 1 year

Frequency: Annual

Study Establishment: School of Oriental and African Studies;

University of Sussex; University of Oxford

Country of Study: United Kingdom

Application Procedure: Applicants must apply to their chosen universities separately and awards are conditional on the applicant being offered a place at the relevant university.

Closing Date: Check the website

Additional Information: Please check at www.canoncollins.org.uk/ ukmasters.html for further details.

\section{Canon Collins Scholarships for Postgraduate Study in \\ South Africa}

Subjects: We offer awards in these areas: (1) Justice, which includes Law, Economics, Politics and the Environment. (2) Education policy and practice. (3) Humanities, which includes Literature, History, Anthropology and the Arts.

Purpose: We believe that southern Africa's development depends on strong leadership in key fields. We seek to invest in those who share our commitment to social justice and who can demonstrate their intention to return to their home countries after their study.

Eligibility: To apply for a scholarship under this programme you must be a national of, or have refugee status in, one of the following countries: Angola, Botswana, Lesotho, Malawi, Mozambique, Namibia, South Africa, Swaziland, Zambia, Zimbabwe, normally resident in one of the above countries, in possession of a good first degree (minimum second class, upper division or equivalent) or about to graduate in the year of application, studying or applying to study at a South African university.

Level of Study: Doctorate, MBA, Postgraduate

Type: Scholarships

Value: R60,000-100,000 per academic year

Frequency: Annual
Application Procedure: The application process will open in June and close in August for study commencing next year. When we are open applicants can access the application system on this webpage. Applicants must apply to their chosen universities separately and awards are conditional on the applicant being offered a place at the relevant university.

Closing Date: Please check website

Additional Information: Please check at www.canoncollins.org.uk/ ccsa.html for further details.

\section{The Graça Machel Scholarship Programme}

Subjects: Justice: economics, politics and the environment; Education: policy and practice; Humanities: literature, history, anthropology and the arts.

Purpose: Canon Collins Educational and Legal Assistance Trust is offering Graça Machel Trust scholarships for Southern Africa's future women leaders.

Eligibility: To apply for a scholarship under this programme you must be: a female, a national of and normally resident in one of the SADC countries: Angola, Botswana, DRC, Lesotho, Madagascar, Malawi, Mauritius, Mozambique, Namibia, South Africa, Swaziland, Tanzania, Zambia, Zimbabwe.

Level of Study: Doctorate, Postgraduate

Type: Scholarship

Value: Full tuition, stipend and other support for Honours, masters and $\mathrm{PhD}$ study at South African universities.

Length of Study: Funding is awarded for up to a maximum of 1 year for Honours, 2 years for Masters and 3 years for $\mathrm{PhD}$

Frequency: Annual

Country of Study: South Africa

Application Procedure: Check website for more details.

Closing Date: Check the website

Additional Information: Please check at www.canoncollins.org.uk/ gracamachel.html for further details.

\section{Kader Asmal Fellowships}

Subjects: Business management, agriculture, food science \& nutrition, public administration, human rights law at Trinity College Dublin.

Purpose: The Kader Asmal Fellowship programme aims to contribute to addressing the skills shortage in South Africa, particularly among members of previously disadvantaged communities, through the provision of 1-year post-graduate training in Ireland to deserving candidates in a number of defined areas.

Eligibility: Applicants must be a South African citizen or a citizen of Zimbabwe holding a South African Permanent Residency Permit. Level of Study: Postgraduate

Type: Fellowship

Value: The fellowships include tuition fees, a return flight to Ireland, and monthly stipend, insurance and a settling in allowance

Length of Study: 1 year

Frequency: Annual

Study Establishment: Universities and Institutes of Technology listed on www.educationinireland.ie

Country of Study: Ireland

No. of awards offered: 8

Application Procedure: The online application form is of primary importance as it serves as the basis for assessment. The online application form can be found on the Canon Collins Trust website, when the call for applications is open.

Closing Date: Check the website

\section{Patrick and Janet Stuart Postgraduate Scholarship}

Subjects: Canon Collins Trust is delighted to offer one scholarship each year in the name of Patrick and Janet Stuart. This is available for students from Lesotho to study at postgraduate level at a South African university.

Eligibility: The students of Lesotho can apply for this postgraduate scholarship.

Value: Awards will be valued at R65,000 for each year of study at master's and PhD level

Length of Study: The funding is for up to a maximum of 2 years for master's and 3 years for PhD

Country of Study: South Africa

No. of awards offered: 1 award 
Application Procedure: Please check website for more details. Closing Date: July 27th

Funding: Trusts

\section{THE CANON FOUNDATION IN EUROPE}

Bovenkerkerweg 59, 1185 XB, Amstelveen, PO Box 2262, Netherlands

Tel: (31) 205458934

Fax: (31) 207128934

Email: foundation@canon-europe.com

Website: www.canonfoundation.org

Contact: Mrs Suzy Cohen, Secretary

The Canon Foundation is a non-profit, grant-making philanthropic organization founded to promote, develop and spread science, knowledge and understanding, in particular, between Europe and Japan.

\section{Canon Foundation Research Fellowships \\ Subjects: All subjects.}

Purpose: To contribute to scientific knowledge and international understanding, in particular between Europe and Japan.

Eligibility: Open to Japanese and European nationals only.

Level of Study: Doctorate, Postdoctorate, Postgraduate, Research Type: Fellowship

Value: Awards ranging from $€ 22,500$ to $€ 27,500$ are offered per year and pro-rata for different periods

Length of Study: Up to 1 year

Frequency: Annual

No. of awards offered: 15

Application Procedure: Applicants must complete an application form, which is to be submitted with two reference letters, a curriculum vitae, a list of papers, two photographs and copies of certificates of higher education.

Closing Date: September 15th

Funding: Corporation, private

Contributor: Canon Europa NV

No. of awards given last year: 12

No. of applicants last year: 176

Additional Information: The Canon Foundation gives priority to those who plan to travel to Europe or Japan rather than prolong a current stay.

\section{CANTERBURY HISTORICAL ASSOCIATION}

History Department, University of Canterbury, Private Bag 4800 , Christchurch, 8140, New Zealand

Tel: (64) 33642555

Fax: (64) 33642003

Email: david.monger@canterbury.ac.nz

Website: www.hums.canterbury.ac.nz/hist/

Contact: Mrs Lynn McClelland, Director of Student Services and Communications

The Canterbury Historical Association (founded 1922, but in recess between 1940 and 1953) aims to foster public interest in all fields of history by holding meetings for the discussion of historical issues, and to promote historical research and writing through its administration of the J M Sherrard Award in New Zealand local and regional history.

\section{J M Sherrard Award}

Subjects: New Zealand regional and local history writing.

Purpose: To foster high standards of scholarship in New Zealand regional and local history.

Eligibility: Open to qualified applicants from New Zealand only. Major awards are normally restricted to substantial monograph length publications that meet scholarly standards. Small-scale works, biographies and family histories are not eligible.

Level of Study: Unrestricted

Type: Prize

Value: New Zealand $\$ 1,000$, which may be divided if there is more than one work deserving a major award

Frequency: Dependent on funds available, biennial
Country of Study: New Zealand

No. of awards offered: Varies

Application Procedure: No application is required, as judges assess all potential titles appearing in the New Zealand National Bibliography

Closing Date: check with website

Funding: Private

Contributor: Canterbury Historical Association

Additional Information: The prize money is often divided among two or three finalists. A commendation list is also published. Please check at www.hums.canterbury.ac.nz/hist/association.shtml for further details.

\section{CARDIFF METROPOLITAN UNIVERSITY}

Llandaff Campus, Western Avenue, Cardiff, Wales, CF5 2YB, United Kingdom

Tel: (44) 02920416070

Fax: (44) 02920416286

Email: scholarship@cardiffmet.ac.uk

Website: www.cardiffmet.ac.uk

Cardiff Metropolitan University is a global university. We are continually investing in our students' future and provide education and training opportunities that are accessible, flexible and of the highest quality to students from over 140 countries worldwide.

\section{Postgraduate Scholarship at Cardiff Metropolitan University}

Purpose: The Postgraduate Scholarship is an award for those studying a full-time taught masters programme at Cardiff Metropolitan University

Eligibility: Applicants should be privately funded; should be a UK or Eu student; must have obtained a first class degree at Cardiff Metropolitan University or another university; must be studying a Cardiff based, full time, taught masters programme. This scholarship is not available to PGCE students.

Level of Study: Postgraduate

Type: Scholarship

Value: The award is a payment towards tuition fees valued at $£ 3,000$.

Country of Study: United Kingdom

Application Procedure: The mode of application is online.

Closing Date: July 31st

Additional Information: Please send any queries or questions to scholarship@cardiffmet.ac.uk.

\section{CARDIFF UNIVERSITY}

\author{
Deri House, 2-4 Park Grove, Wales, Cardiff, CF10 3PA, \\ United Kingdom \\ Tel: (44) 2920870084 \\ Fax: (44) 2920870085 \\ Email: graduate@cardiff.ac.uk \\ Website: www.cardiff.ac.uk/postgraduate
}

Cardiff University is recognized in independent government assessments as one of the UK's leading teaching and research universities. Founded by Royal Charter in 1883, the University today combines impressive modern facilities and a dynamic approach to teaching and research with its proud heritage of service and achievement. Having gained national and international standing, Cardiff University's vision is to be recognized as a world-class university and to achieve the associated benefits for its students, staff and all other stakeholders.

\section{Cardiff University Jameel MA Scholarships in Islam in Contemporary Britain}

Subjects: Scholarships are awarded for studying MA in Islam in Contemporary Britain program.

Eligibility: A first class or very high upper-second class honors degree in a relevant subject (religious studies, islamic studies, social sciences, philosophy or history) from a U.K. university. Full awards are open only to U.K. and EU nationals who satisfy U.K. residency requirements. Priority will be given to candidates with a demonstrable record of interest in, and/or enthusiasm for, working with British Muslims.

Level of Study: Postgraduate 
Type: Scholarship

Value: Each successful Cardiff University Jameel Scholar has full UK/EU tuition fees paid and receives a generous stipend (of approx. $£ 16,000$ ) equivalent to an AHRC stipend plus a research allowance for books/conferences. Full-time MA awards will provide funding for 1 year. Length of Study: 1 year

Country of Study: United Kingdom

No. of awards offered: 3

Application Procedure: For information please visit website.

Closing Date: January

Additional Information: Duration of scholarship is 1-year full-time.

\section{Fully-Funded PhD Studentship in Sustainable Place- \\ Making}

Eligibility: Residency: full awards (fees plus maintenance stipend) are open to U.K. nationals and EU students without further restrictions. Academic criteria: successful applicants are likely to have a very good first degree (a first or upper second class BA or BSc Honours or equivalent), and an appropriate Masters degree in a relevant subject (e.g. social sciences; environmental studies; sustainable development; environmental psychology; sociology of technology/environment; human geography), with an average mark of at least 65).

Level of Study: Postgraduate, Research

Type: Studentship

Value: Full UK/EU tuition fees, as well as a doctoral stipend matching U.K. Research Council National minimum ( $£ 13,863$ per year for current year, updated each year)

Length of Study: 3 years

Country of Study: United Kingdom

No. of awards offered: 1

Application Procedure: (1) Submit a complete application form for admission to doctoral study in the School of Social Sciences,

submitted to the Academic Registry via the online admissions portal (www.cardiff.ac.uk/regis/general/applyonline/index.html). Please specify the School of Social Sciences - Research Degree - Doctor of Philosophy (social sciences) with a start date of January. (2) Submit the following documentation (attached to a single email with the subject PLACE PhD Studentship 2016) to Parkinva@cardiff.ac.uk with a letter of application, stating your reasons for wishing to pursue $\mathrm{PhD}$ study; a full research proposal for the PhD study (maximum 1,000 words, excluding references); a curriculum vitae; official transcripts of previous higher education qualifications; two academic references. Closing Date: November 17th

Additional Information: Cardiff University reserves the right to close applications early should sufficient applications be received.

For further information contact:

Tel: 02920870855

Email: parkinva@cardiff.ac.uk

Contact: Victoria Parkin

\section{Morgan E. Williams MRes Scholarship in Helminthology}

Subjects: Scholarship is awarded for research project in helminth parasitology as part of the Masters of Research in Bio sciences at Cardiff School of Bio sciences.

Eligibility: English language proficiency is required. Applicants must have a undergraduate degree at level 2:2 (or higher) in a relevant biological, bio medical or bio-molecular science subject. For detailed information, please visit the website.

Level of Study: Postgraduate

Type: Scholarship

Value: There is one scholarship offering a reduction of $£ 2,500$ off the tuition fees for MRes Biosciences

Country of Study: United Kingdom

Application Procedure: Applicants should submit a curriculum vitae and Covering Letter to Rachel Patterson, PatersonRJ@cardiff.ac.uk. Closing Date: May

Contributor: Cardiff School of Bio sciences

Additional Information: Scholarship is offered for 1 year.

\section{PhD Scholarship in Computer Science \& Informatics}

Subjects: Computer science \& informatics.

Eligibility: Candidates should either have a good honours degree in a relevant discipline (minimum 2:1) or have (or expect to have from
Autumn) a Masters qualification in a relevant discipline, with distinction in the project or have professional qualifications deemed by Cardiff University to be equivalent to the above or be over 25 and have relevant work experience in a position of responsibility. Applicants whose first language is not English will be required to demonstrate proficiency in the English language (IELTS 6.5 or equivalent).

Type: Scholarship

Value: Full tuition fees

Length of Study: 3 years

Country of Study: United Kingdom

No. of awards offered: 1

Application Procedure: Consideration is automatic on applying for the $\mathrm{PhD}$ in Computer Science and Informatics with an October start. In the Research Project Title field, applicants need to enter 'ECR Scholarship', followed by the title of the project they wish to apply. Closing Date: May 1st

Additional Information: Scholarship is offered for 3 years. Please refer website for further details: http://courses.cardiff.ac.uk/funding.

\section{PhD Studentship in Biological Chemistry at Cardiff University \\ Subjects: Biological chemistry.}

Eligibility: Residency: full awards (fees plus maintenance stipend) are open to U.K. nationals and EU students who can satisfy U.K. residency requirements. To be eligible for the full award, EU Nationals must have been in the UK for at least 3 years prior to the start of the course for which they are seeking funding, including for the purposes of full-time education. EU Nationals who do not meet the above residency requirement are eligible for a fees only award, provided that they have been ordinarily resident in the EU for at least 3 years prior to the start of their proposed programme of study. Academic criteria: applicants should have, or expect to obtain, a good honours degree (at least 2.1) or equivalent in chemistry, biochemistry or a related discipline.

Level of Study: Research, Doctorate, Postdoctorate

Type: Studentship

Value: Full UK/EU tuition fees, as well as a doctoral stipend matching U.K. Research Council National minimum (£13,863 per year for current year, updated each year)

Length of Study: 3 years

Frequency: Annual

Country of Study: United Kingdom

No. of awards offered: 1

Application Procedure: In the first instance, you should submit a curriculum vitae and covering letter, with the names and addresses of two referees to Dr Loveridge by emailing LoveridgeEJ@cardiff.ac.uk. The successful candidate will then be invited to submit a standard application for postgraduate study via the online application service.

Closing Date: January 31st

Contributor: School of Chemistry

Additional Information: The project can either be on novel applications of NMR spectroscopy to biomacromolecules, or on antibiotic biosynthesis and resistance. Cardiff University reserves the right to close applications early should sufficient applications be received. Please refer website for further details: http://courses.cardiff. ac.uk/funding.

\section{PhD Studentship in Energy and Carbon Emissions}

Subjects: Project Title: 2050 Energy and Carbon Emissions Pathways: Modeling the Cost of Decarbonisation.

Eligibility: Applicants should hold or expect to gain an undergraduate degree in a relevant discipline (2.1 or 1st class honors) and/or an appropriate Masters level qualification. Applicants whose first language is not English will be required to demonstrate proficiency in the English language (IELTS 6.5 or equivalent).

Level of Study: Doctorate

Value: Fees at the Home/EU fee rate and will provide an annual stipend $(£ 13,726)$.

Length of Study: 3 years

Country of Study: United Kingdom

No. of awards offered: 1

Application Procedure: Mode of applying is online.

Closing Date: November 30th

Contributor: UK Department of Energy and Climate Change (DECC) 
Additional Information: Full award is open to Home students, or EU candidates who have been resident in the UK for 3 years at the course start date. Other EU applicants may be eligible for a fees-only award.

\section{PhD Studentship in Inorganic Chemistry at Cardiff University \\ Subjects: Inorganic chemistry.}

Eligibility: Residency: full awards (fees plus maintenance stipend) are open to U.K. nationals and EU students without further restrictions. Academic criteria: The successful applicant will likely have a good first degree (the equivalent of a 2.i or higher) and a Masters in chemistry. First-hand experience in a relevant area of chemistry such as Synthetic chemistry, Main Group chemistry or Catalysis is highly desirable, including familiarity with glovebox and Schlenk-line techniques and multi-nuclear NMR spectroscopy. A selfstarter with good interpersonal skills and a drive to succeed, you will be highly motivated and relish the opportunity to take a leading role in establishing this new research program.

Level of Study: Postgraduate, Research

Type: Studentship

Value: Full UK/EU tuition fees, as well as a doctoral stipend matching U.K. Research Council National minimum ( $£ 13,863$ per year for current year, updated each year)

Length of Study: 3 years

Country of Study: United Kingdom

No. of awards offered: 1

Application Procedure: In the first instance, you should submit a curriculum vitae and covering letter outlining your motivation and experience for the position to Dr Rebecca Melen by emailing (MelenR@cardiff.ac.uk). The successful candidate will then be invited to submit a standard application for postgraduate study via the online application service.

Closing Date: November 30th

\section{PhD Studentship in Organisms and Environment at Cardiff University}

Subjects: Organisms and environment (fungal ecology).

Eligibility: Residency: full awards (fees plus maintenance stipend) are open to U.K. nationals and EU students who can satisfy U.K. residency requirements. To be eligible for the full award, EU nationals must have been in the UK for at least 3 years prior to the start of the course for which they are seeking funding, including for the purposes of full-time education. EU nationals who do not meet the above residency requirement are eligible for a fees only award, provided that they have been ordinarily resident in the EU for at least 3 years prior to the start of their proposed programme of study. Academic criteria: applicants for a studentship must have obtained, or be about to obtain, a 2.1 degree or higher in microbiology, ecology, biology or other relevant discipline. If you have a 2.2 degree, but have also obtained a Masters qualification, you are also eligible. If you do not have these qualifications but you have substantial relevant postgraduate experience please contact the department holding the studentship to find out if your relevant experience is sufficient.

Level of Study: Doctorate, Postgraduate, Research

Type: Studentship

Value: This studentship consists of full UK/EU tuition fees, as well as a Doctoral Stipend matching UK Research Council National Minimum.

Length of Study: 3.5 years

Frequency: Annual

Country of Study: United Kingdom

Application Procedure: To apply, please email your curriculum vitae, 2 references and relevant academic qualifications along with a covering letter to Professor Lynne Boddy at BoddyL@cf.ac.uk. Closing Date: January 15th

Additional Information: Internal interviews will be conducted before the January 30th. Shortlisted candidates will then go on to an institutional interview which will take place between February 9th and 20th. Cardiff University reserves the right to close applications early should sufficient applications be received.

\section{For further information contact:}

\section{Email: BoddyL@cf.ac.uk}

Website: http://courses.cardiff.ac.uk/funding/R2342.html

Contact: Professor Lynne Boddy

\section{PhD Studentship in Renewable Energy at Cardiff University \\ Purpose: Renewable energy.}

Eligibility: Residency: full awards (fees plus maintenance stipend) are open to U.K. nationals and EU students who can satisfy U.K. residency requirements. To be eligible for the full award, EU nationals must have been in the UK for at least 3 years prior to the start of the course for which they are seeking funding, including for the purposes of full-time education. EU nationals who do not meet the above residency requirement are eligible for a fees only award, provided that they have been ordinarily resident in the EU for at least 3 years prior to the start of their proposed programme of study. Academic criteria: candidates should hold or expect to gain a first class numerate degree or a good 2.1 and/or an appropriate Master's level qualification (or their equivalent). Applicants whose first language is not English will be required to demonstrate proficiency in the English language (IELTS 6.5 or equivalent).

Level of Study: Postgraduate, Research

Type: Studentship

Value: Full UK/EU tuition fees, as well as a doctoral stipend matching UK Research Council National minimum ( $£ 13,863$ per year for current year, updated each year)

Length of Study: 3.5 years

Frequency: Annual

Country of Study: United Kingdom

No. of awards offered: 1

Application Procedure: In the first instance, you should submit a curriculum vitae and covering letter to Ms $\mathrm{J}$ Cleaver at engineeringpgr@cf.ac.uk.Please ensure that you quote the studentship reference CUL-HUBNET-2014 in the email subject field. Shortlisted candidates will then be invited to submit a standard application for postgraduate study via the online application service.

Closing Date: November 30th

Additional Information: Informal enquiries should be directed to Dr Carlos Ugalde-Loo by emailing Ugalde-LooC@cardiff.ac.uk.

\section{Postgraduate Taught Scholarships}

Subjects: All subjects.

Purpose: To support postgraduate study and training.

Eligibility: This scholarship package will give high-calibre students the opportunity to study at a world-leading, research-intensive university and help ease the associated financial burdens.

Level of Study: Postgraduate

Type: Studentship

Value: $£ 3,000$

Length of Study: 1 year

Frequency: Annual

Study Establishment: Cardiff University

Country of Study: United Kingdom

Application Procedure: Scholarships will be awarded based on academic excellence. Application forms will be available for download from within the SIMS Online Application Portal from early January.

Closing Date: August 1st

Additional Information: Please check at www.cardiff.ac.uk/for/ prospective/postgraduate/funding/master-scholarships.html for further details.

\section{President's Research Scholarship}

Subjects: Energy Networks.

Purpose: The Scholarship provides an opportunity for high calibre applicants to work on exciting and challenging projects in dynamic and well-resourced research environments under the supervision of successful and established researchers.

Eligibility: Candidates should hold or expect to gain a first class degree or a good 2.1 and/or an appropriate Master's level qualification (or their equivalent) in Electrical Engineering or related discipline. Applicants whose first language is not English will be required to demonstrate proficiency in the English language (IELTS 6.5 or equivalent).

Level of Study: Doctorate

Type: Scholarships

Value: Each PhD project will be funded for 3 years. The award includes full UK/EU tuition fees plus a doctoral stipend matching UK Research Council National Minimum.

Country of Study: United Kingdom

No. of awards offered: One

Application Procedure: Interested applicants are invited to send a curriculum vitae and covering email/letter to Julie Cleaver 
(CleaverJ@Cardiff.ac.uk) and ensure that they quote the reference number in the subject field of the email. Shortlisted candidates will be invited to submit an online application form.

Closing Date: August 16th

Additional Information: Please refer website for more details:

http://courses.cf.ac.uk/funding/R499.html.

\section{Ursula Henriques Scholarships}

Subjects: Scholarships are awarded to study the subjects offered by the university.

Purpose: Scholarships are available for pursuing postgraduate taught and postgraduate research programme.

Eligibility: For eligibility details, please visit website http://scholarship-positions.com/ursula-henriques-scholarships-uk-eu-international-students/2018/03/30/.

Level of Study: Postgraduate, Research

Value: In January 2001 Cardiff University received a gift of $£ 100,000$ from Professor Henriques (1914-2008), a former member of staff in the Department of History and Welsh History, University College Cardiff

No. of awards offered: 2 scholarships

Application Procedure: The application form can be obtained by

email. Completed forms should be returned electronically to the

School Postgraduate Office.

Closing Date: May 18th

Contributor: Cardiff University

Additional Information: For more details, please visit website https://www.cardiff.ac.uk/study/postgraduate/funding/view/ Ursula-Henriques-Scholarship.

\section{CARGILL}

Cargill India Pvt. Ltd. 14th Floor, Building 9 A DLF Cyber City, Phase III, Gurgaon, 122002 (Haryana), India

Tel: (91) 1242358939

Fax: (91) 1242358973

Email: cargillglobalscholarsindia@iie.org

Website: www.cargill.co.in

Cargill is an international producer and marketer of food, agricultural, financial and industrial products and services. Founded in 1865, the privately held company employs 140,000 people in 65 countries.

\section{Cargill Global Scholars Program}

Subjects: Scholarships are provided in the field of food, agriculture and risk management.

Purpose: Cargill offers Global Scholars Program to talented, high performing university students who demonstrate exemplary academic achievement and leadership potential.

Eligibility: Applicants to the Cargill Global Scholars program must be a citizen or permanent legal resident of Brazil, China, India, Russia, or the US; attend a partner university in the country of citizenship or permanent legal residency; be a first or second year university student; demonstrate high academic performance; demonstrate leadership potential. Each program country has a unique set of eligibility criteria. To learn about the country-specific eligibility criteria, please visit the website.

Type: Scholarship

Value: Annual scholarship award for up to 2 years, to help off-set any academic related expenses.

Application Procedure: The mode of applying is online.

Closing Date: March 1st

Contributor: Cargill

Additional Information: The Cargill Global Scholars Program is currently available in Brazil, China, India, Russia, and the US. Scholarship is offered for up to 3 years. Please visit www.cargillglobalscholars.com/scholarship.

\section{CARIM}

PO Box 616, Maastricht, 6200 MD, Netherlands Contact: CARIM

CARIM is one of the top institutes for translational cardiovascular research in Europe. It is among the world leaders in the fields of research into vascular and thrombotic disorders and atrial fibrillation as well as translational heart failure research. It has also made important international contributions to molecular imaging in the cardiovascular field.

\section{CARIM Postdoctoral Talent Fellowship}

Subjects: The "CARIM - Postdoctoral Talent Fellowship" has been designed to support talented CARIM PhD students in realising an ambitious, innovative and international one-year research project as a postdoc. The "CARIM - Postdoctoral Talent Fellowship" is intended for recently graduated CARIM PhD students.

Purpose: Purpose is to provide recently promoted top CARIM talent a chance to gain experience abroad and return to CARIM to perform excellent research.

Eligibility: For eligibility details, please visit the website https://www.scholarshipsupdates.com/carim-postdoctoral-talentfellowship-for-international-students-to-study-abroad-2018-19/. Level of Study: Postdoctorate

Value: The fellowship amounts to $€ 53,011$ gross (in accordance with 2016 scale 10-4 for salary costs) which is meant for a period of 12 months. Bench fees are not included in this fellowship. The fellowship includes one return flight to the host institute (based on economy fare) Application Procedure: There will be one call a year, and the deadline for the "CARIM - Postdoctoral Talent Fellowship" is the 13th of May, 00.00 hours. To apply for the "CARIM - Postdoctoral Talent Fellowship", the applicants from within (or connected to) CARIM are invited to submit an application (by mail) to the CARIM office (secretariaat-carim-at-maastrichtuniversity.nl).

Closing Date: May 13th every year

\section{CARNEGIE CORPORATION OF NEW YORK}

437 Madison Avenue, New York, NY 10022, United States of America

Tel: (1) 2123713200

Fax: (1) 2127544073

Website: www.carnegie.org

Andrew Carnegie envisioned Carnegie Corporation as a foundation that would promote the advancement and diffusion of knowledge and understanding. In keeping with this mandate, our work incorporates an affirmation of our historic role as an education foundation but also honors Andrew Carnegie's passion for international peace and the health of our democracy.

\section{Brazilian Nuclear History Fellowship for International Fellows}

Subjects: The Nuclear Proliferation International History Project is pleased to announce a 3-month research fellowship for a scholar studying Brazil's nuclear history, in particular as it relates to US-Brazil relations, Brazil's nuclear relations with Argentina and with other countries, and Brazil's evolving role in the NPT regime.

Purpose: The fellowship, made possible by a generous grant from the Carnegie Corporation of New York, will provide a unique opportunity to conduct archival and oral history research on Brazil's nuclear history using Brazilian archives.

Eligibility: The ideal candidate will be an advanced PhD candidate, postdoctoral researcher, or early career academic with an interest in Brazil's nuclear program from a scholarly perspective. The fellowship will be awarded preferably to a candidate who has not yet had the opportunity to conduct nuclear history research in Brazilian archives. The fellowship will be awarded to an individual with substantial academic and professional accomplishments, a compelling research question, and the ability to connect research conducted during their proposed fellowship to their own ongoing body of academic research.

Type: Fellowship

Value: It includes a monthly stipend of $\mathrm{R} \$ 5,000$ (Brazilian Reais), an economy return ticket to and from Rio de Janeiro, and full access to Fundação Getulio Vargas facilities in Rio de Janeiro

Frequency: Annual

Application Procedure: Interested candidates must submit a curriculum vitae, the names of two referees, and a proposal (maximum 1,000 words) outlining the project, the work they propose to conduct whilst in Brazil, and the envisaged outcomes. 
Closing Date: December 15th

Additional Information: Please direct all application materials and inquiries to ri@fgv.br.

\section{Next Gen Fellowship Program for Sub-Saharan African Countries}

Subjects: The fellowships support dissertations and research on peace, security and development topics.

Purpose: This fellowship is available for pursuing $\mathrm{PhD}$ research level. Eligibility: All applicants must be citizens of and reside in a sub-Saharan African country while holding a current faculty position at an accredited college or university in Ghana, Nigeria, South Africa, Tanzania, or Uganda. Applicants for any of the funding opportunities offered through this program must have a master's degree and be working toward completion of the doctoral degree. The program seeks to promote diversity and encourages women to apply. To be eligible for the US $\$ 15,000$ dissertation research fellowship, applicants must have an approved dissertation proposal but will not yet have undertaken research of 9 months or more. For detailed information, please visit website. Level of Study: Doctorate

Type: Fellowship

Value: The doctoral dissertation proposal fellowship supports shortterm research costs of up to US $\$ 3,000$ to develop a doctoral dissertation proposal. The doctoral dissertation completion fellowship supports a 1-year leave from teaching responsibilities and a stipend up to US $\$ 15,000$ to permit the completion of a dissertation that advances research on peace, security, and development topics. The doctoral dissertation research fellowship supports 9-12 months of dissertation research costs of up to US $\$ 15,000$ on a topic related to peace, security, and development

Length of Study: About 9-12 months

Country of Study: Africa

No. of awards offered: 45

Application Procedure: The mode of applying is online. All applications must be submitted using the online application portal. Closing Date: November 13th

Additional Information: Citizens of and reside in a sub-Saharan African country while holding a current faculty position at an accredited college or university in Ghana, Nigeria, South Africa, Tanzania, or Uganda can apply for this $\mathrm{PhD}$ fellowship.

\section{CARNEGIE MELLON UNIVERSITY}

5000 Forbes Ave, Pittsburgh, Adelaide, PA 15213, Australia Tel: (61) 4122682000 Fax: (61) 0882119444

Email: admissions@cmu.edu.au

Website: http://www.cmu.edu/index.shtml

Carnegie Mellon is home to the world's leading experts in a range of fields. From computing to the arts to the environment to biotechnology, the students, faculty and staff of the University are shaping the future with a strong focus on finding practical answers to complex problems. These scholarships are available to full-time students.

\section{Carnegie Mellon University-Aus AID Scholarships}

Subjects: Public policy, management and information technology. Purpose: CMU-AusAID Scholarships aim to strengthen human resource capacity in partner countries in public policy, management and information technology. CMU-AusAID Scholarships enable individuals from partner countries to gain high-level skills and knowledge in these areas, so that they can contribute to the economic and social development of their home countries.

Eligibility: Open to students who have already been offered a place at Carnegie Mellon University in either of the two courses available under this program.

Type: Scholarship

Value: Full tuition fee, return economy airfares, a contribution to living expenses, and basic medical insurance

Length of Study: 1 year

Frequency: Annual

Study Establishment: Carnegie Mellon University

Country of Study: Australia

No. of awards offered: Varies

Application Procedure: Check website for further details.
Closing Date: See the website

Funding: Government

Contributor: Government of Australia

Additional Information: Please check at www.australia.cmu.edu/

study/scholarships for further details.

\section{THE CARNEGIE TRUST FOR THE UNIVERSITIES OF SCOTLAND}

\author{
Andrew Carnegie House, Pittencrieff Street, Dunfermline, \\ Fife, KY12 8AW, Scotland \\ Tel: (44) 1383724990 \\ Fax: (44) 1383749799 \\ Email: admin@carnegie-trust.org \\ Website: www.carnegie-trust.org \\ Contact: Dr Patricia Krus, Administrative Manager
}

The Carnegie Trust for the Universities of Scotland, founded in 1901, is one of the many philanthropic agencies established by Andrew Carnegie. The trust aims to offer assistance to students, to aid the expansion of the Scottish universities and to stimulate research. See also the entry for the Caledonian Scholarships.

\section{Research Incentive Grants}

Purpose: To provide research funding for academic staff at Scottish universities.

Eligibility: Open to academic members of staff of a Scottish university. Please check detailed information at www.carnegie-trust. org/schemes/research-schemes/research-incentive-grants. html\#eligibility.

Level of Study: Research

Type: Grant

Value: The maximum award that can be applied for is $£ 7,500$ and the minimum is $£ 500$

Frequency: Biannual

Application Procedure: Apply online on the trust's website. Closing Date: March 15th and September 15th

Additional Information: If you experience technical problems with the online submission, contact the Trust immediately by email (admin@carnegie-trust.org) or phone (01383 724 990). The office is open from 9 am to 5 pm on weekdays. Please do not wait until after the deadline to report technical issues.

\section{CATHOLIC ACADEMIC EXCHANGE SERVICE (KAAD)}

Katholischer Akademischer, Ausländer-Dienst, Hausdorffstr street 151, Bonn, 53129, Germany Tel: (49) 228917580 Fax: (49) 2289175858 Email: zentrale@kaad.de Website: www.kaad.de

Catholic Academic Exchange Service (KAAD) provides financial and civic educational support as well as pastoral assistance for highpotential post-graduate scholars from Africa, Asia, Latin America, the Middle East and Eastern Europe. The KAAD has been registered as a charity of the German Catholic Church since 1958. Today it is the largest Catholic Organization offering scholarships in the area of International educational collaboration in the world.

\section{Research Scholarships: Programme I}

Subjects: All subjects.

Purpose: To support candidates from developing nations, who are still in their home countries, for doctoral and postdoctoral research. Eligibility: Applicants must be young academics from Asia, Africa, Latin America, Near and Middle East or Eastern Europe, with a commitment to return to their home country upon completion of their research stay.

Level of Study: Postgraduate, Doctorate, MBA, Research,

Postdoctorate

Type: Scholarship

Value: In accordance with KAAD scholarship guidelines

Length of Study: 1 year (extendable up to 3 years) 


\section{Frequency: Annual}

Study Establishment: A German university

Country of Study: Germany

Application Procedure: Application forms are available on request.

Applications can be submitted to the KAAD partner organizations in the home country, which in turn will propose the applicants to the KAAD. Closing Date: January 15th and June 15th (check with website) Contributor: Catholic Academic Exchange Service (KAAD) Additional Information: Please check at http://kaad.de/1/ scholarships/ for further details.

\section{Research Scholarships: Programme II}

Subjects: All subjects.

Purpose: To support candidates from developing nations, who are already in Germany and are in an advanced stage of their research and whose research is not yet promoted by KAAD.

Eligibility: Applicants must be young academics from Asia, Africa, Latin America, Near and Middle East or Eastern Europe, with a commitment to return to their home country upon completion of their research stay.

Level of Study: Postgraduate, Postdoctorate, Doctorate, MBA

Type: Scholarship

Value: In accordance with KAAD scholarship guidelines

Length of Study: 1 year (extendable up to 3 years)

Frequency: Annual

Study Establishment: A German university

Country of Study: Germany

Application Procedure: Application forms are available on request. Applications can be submitted to the KAAD partner organizations in Germany, which in turn will propose the applicants to the KAAD. Closing Date: January 15th and June 15th (check with website) Contributor: Catholic Academic Exchange Service (KAAD) Additional Information: Please check at http://kaad.de/1/ scholarships/scholarship-program-2/ for further details.

\section{CATHOLIC LIBRARY ASSOCIATION (CLA)}

8550 United Plaza Blvd, Ste 1001, Baton Rouge, LA, 606065061 , United States of America

Tel: (1) 2254084417

Fax: (1) 3127391778

Email: cla@cathla.org

Website: www.cathla.org

The Catholic Library Association (CLA) represents all segments of the library community. Members strive to initiate, foster and encourage any activity or library programme that will promote literature and libraries, not only of a Catholic nature, but also of an ecumenical spirit.

\section{Rev Andrew L Bouwhuis Memorial Scholarship}

\section{Subjects: Library science.}

Purpose: To encourage promising and talented individuals to enter librarianship and to foster advanced study in the library profession. Eligibility: Open to individuals who have been accepted into a graduate school programme, show promise of success based on collegiate record and who demonstrate the need for financial aid. Level of Study: Graduate, Postgraduate

Type: Award

Value: US $\$ 1,500$

Frequency: Annual

Country of Study: United States of America

No. of awards offered: 1

Application Procedure: Applicants must complete an application form, available at www.cathla.org or on request. Please send a stamped addressed envelope.

Closing Date: February 1st (check with website)

Funding: Private

No. of awards given last year: 1

Additional Information: Please check at www.cathla.org/scholarships-grants/rev-andrew-I-bouwhuis further details.

\section{For further information contact:}

Scholarship Committee, Catholic Library Association, 205 West Monroe Street, Suite 314, Chicago, IL, 606065061
Sister Sally Daly - Junior Library Guild Grant

Subjects: Library science.

Purpose: To enable a new CLA/CLSS member to attend the Association's annual convention.

Eligibility: Only new members of the Catholic Library Association (CLA)/Children's Library Services Section (CLSS) are eligible.

Type: Award

Value: US $\$ 1,500$

Frequency: Annual

No. of awards offered: 1

Application Procedure: Applications may be obtained by writing to the Association or downloaded from the Association's website.

Closing Date: February 1st (check with website)

Contributor: Junior Library Guild

No. of awards given last year: 1

No. of applicants last year: 2

Additional Information: Currently on hold, contact the organization for update. Please check at www.cathla.org/scholarships-grants/ sister-sally-daly for further details.

For further information contact:

Sister Sally Daly Memorial Grant, Catholic Library Association, 205 West Monroe Street, Suite 314, Chicago, IL, 606065061

\section{CATHOLIC UNIVERSITY OF LOUVAIN}

1, Place de l'Université, B-1348 Louvain-la-Neuve, Belgium Tel: (32) 010472111

Fax: (32) 010472999

Website: www.uclouvain.be

\section{Hoover Fellowships for International Scholars}

Eligibility: Candidates must be scholars from outside Belgium, who hold a doctorate or possess equivalent qualifications and are active in the field of economic or social ethics broadly conceived. Candidates for a full fellowship must have no professional income from other sources in the period concerned. Proficiency in either English or French is required, and at least a passive knowledge in both is desirable.

Type: Fellowship

Value: One full Hoover fellowship of $€ 2,000$ per month (plus social security contributions) for a duration of 3 months. Several honorary Hoover fellowships for a duration of 1 to 6 months with a contribution to housing and travelling costs of up to $€ 500$ per month

Frequency: Annual

Study Establishment: UCL

Country of Study: Belgium

Application Procedure: Applications must reach Thérèse Davio by email (therese.davio@uclouvain.be) by the deadline.

Closing Date: February

Contributor: UCL

Additional Information: For more information, please visit www.uclouvain.be/398682.html.

\section{CEC ARTSLINK}

291 Broadway, 12th Floor, New York, NY 10007, United States of America Tel: (1) 2126431985

Fax: (1) 2126431996

Email: info@cecartslink.org

Website: www.cecartslink.org

CEC Artslink is an international arts service organization. Our programmes encourage and support exchange of artists and cultural managers between the US and Central Europe, Russia, and Eurasia. We believe that the arts are a society's most deliberate and complex means of communication.

\section{ArtsLink Independent Projects}

Subjects: Performing, design, media, literary and visual arts. Purpose: To provide funding to artists and arts managers who propose to undertake projects in the US in collaboration with a U.S. non-profit arts organization. 
Eligibility: Candidates must be citizens of, and reside in, an eligible countries Albania, Armenia, Azerbaijan, Belarus, Bosnia and Herzegovina, Bulgaria, Croatia, Czech Republic, Estonia, Georgia, Hungary, Kazakhstan, Kosovo, Kyrgyzstan, Latvia, Lithuania, Macedonia, Moldova, Mongolia, Montenegro, Poland, Romania, Russia, Serbia, Slovak Republic, Slovenia, Tajikistan, Turkmenistan, Ukraine and Uzbekistan. There are no age limitations. Arts managers must be affiliated with an organization in the non-commercial sector.

Type: Fellowship

Value: $\$ 5,000$

Length of Study: 1 year

Frequency: Annual

Country of Study: United States of America

Application Procedure: Complete online application form.

Closing Date: December

Funding: Private, trusts

No. of awards given last year: 5

Additional Information: Please check at www.cecartslink.org/grants/ independent_projects/ for further details.

For further information contact:

CEC ArtsLink, 435 Hudson Street, 8th Floor, New York, NY 10014 Email: al@cecartslink.org

\section{ArtsLink Projects}

Subjects: Performing Arts, visual and media arts.

Purpose: To support U.S. artists, curators, presenters, and non-profit arts organizations undertaking projects in Eastern and Central Europe, Russia, Central Asia and the Caucasus.

Eligibility: Open to citizens of eligible countries: Albania, Armenia, Azerbaijan, Belarus, Bosnia and Herzegovina, Bulgaria, Croatia, Czech Republic, Estonia, Georgia, Hungary, Kazakhstan, Kosovo, Kyrgyzstan, Latvia, Lithuania, Macedonia, Moldova, Mongolia, Montenegro, Poland, Romania, Russia, Serbia, Slovak Republic, Slovenia, Tajikistan, Turkmenistan, Ukraine and Uzbekistan.

Level of Study: Postgraduate

Type: Fellowship

Value: Up to US $\$ 10,000$

Length of Study: 1 year

Frequency: Annual

Application Procedure: Complete online application form

Closing Date: January 15th (Performing arts and literature application) and January 15th (Visual and media arts application)

Funding: Private, trusts

No. of awards given last year: 10

Additional Information: Please check at www.cecartslink.org/grants/ artslink_projects/ for further details.

For further information contact:

Tel: 2126431985

Email: al@cecartslink.org

\section{ArtsLink Residencies}

Subjects: Literature, Performing arts, Visual and Media Arts.

Purpose: To create opportunities for artists and communities across the US to share artistic practices with artists and arts managers from abroad and engage in dialogue that advances understanding across cultures.

Eligibility: Applicants must be the citizens of, and reside in, eligible countries: Albania, Armenia, Azerbaijan, Belarus, Bosnia and Herzegovina, Bulgaria, Croatia, Czech Republic, Estonia, Georgia, Hungary, Kazakhstan, Kosovo, Kyrgyzstan, Latvia, Lithuania, Macedonia, Moldova, Mongolia, Montenegro, Poland, Romania, Russia, Serbia, Slovak Republic, Slovenia, Tajikistan, Turkmenistan, Ukraine and Uzbekistan.

Level of Study: Postgraduate

Type: Fellowship

Value: offers artists and arts managers from eligible overseas countries a 5-week residency at an established, non-profit arts organization in the US

Length of Study: 5 weeks

Frequency: Annual

Country of Study: United States of America

No. of awards offered: 14-16

Application Procedure: Complete online application form.

Closing Date: October 15th
Funding: Private, trusts

Contributor: ArtsLink Residencies are funded through public and private sources including CEC ArtsLink, the National Endowment for the Arts, the Trust for Mutual Understanding, the Ohio Arts Council, the Kettering Fund and the Milton and Sally Avery Arts Foundation with additional support from the Polish Cultural Institute and the Romanian Cultural Institute

No. of awards given last year: 16

Additional Information: Please check at www.cecartslink.org/grants/ artslink_residencies/for further details.

For further information contact:

Email: al@cecartslink.org

\section{CENTER FOR CREATIVE PHOTOGRAPHY (CCP)}

The University of Arizona, 1030 North Olive Road, Tucson, AZ, 210103, United States of America

Tel: (1) 5206217970

Fax: (1) 5206219444

Email: info@ccp.library.arizona.edu Website: www.creativephotography.org/

The Center for Creative Photography (CCP) is an archive and research centre located on the University of Arizona campus.

\section{CCP Ansel Adams Research Fellowship}

Subjects: Curating/Research.

Purpose: To promote and support research on the Center's photograph, archive and library collections.

Eligibility: Open to researchers from any discipline who are engaged in studies that require an extended period of research in the collections of the Center.

Level of Study: Research

Type: Fellowship

Value: Awards up to $\$ 5,000$ to promote new knowledge about

photography and the history of photography.

Length of Study: 2-4 weeks

Frequency: Annual

Country of Study: United States of America

Application Procedure: Applicants must send a cover letter along with 5 copies each of a curriculum vitae and a statement detailing the applicant's research interests.

Closing Date: January 16th

Additional Information: Please check at www.creativephotography. org/study-research/fellowships-internships for further details.

For further information contact:

Center for Creative Photography, 1030 N. Olive Road, Tucson, AZ 85721-0103

Fax: 5206219444

Email: cass@ccp.library.arizona.edu

Contact: Cass Fey, Curator of Education

\section{THE CENTER FOR CROSS-CULTURAL STUDY (CC-CS)}

Spanish Studies Abroad, The Center for Cross-Cultural Study, 446 Main Street, Amherst, MA, 01002, United States of America Tel: (1) 4132560011

Fax: (1) 4132561968

Email: info@spanishstudies.org

Website: www.spanishstudies.org

The CC-CS provides unique learning experiences for students in a true cross-cultural exchange by inviting them to expand their worldview through intense immersion in Seville, Havana and Cordoba. The CC-CS has developed its reputation from an emphasis on the personal growth of students.

\section{CC-CS Scholarship Program}

Subjects: Cultural studies, Spanish studies.

Purpose: To fund continuing excellence in Spanish studies. 
Eligibility: Open to all students enroled on the cross-cultural scholarship programme in Spain, Argentina and Cuba. Level of Study: Doctorate, Postdoctorate, Postgraduate Type: Scholarship

Value: $\$ 100-500$

Length of Study: 1 year

Frequency: Annual

Study Establishment: The center for cross-cultural study

Country of Study: Argentina

No. of awards offered: Varies

Application Procedure: Submit application accompanied by an original essay in Spanish, Portuguese and English, and a faculty recommendation.

Closing Date: Check the website

No. of awards given last year: 11

Additional Information: Please check at www.spanishstudies.org/ scholarships.html for further details

\section{CENTER FOR DEFENSE INFORMATION (CDI)}

1100 G Street NW, Suite 500, Washington, DC, 20005-3806,

United States of America

Tel: (1) 2023471122

Fax: (1) 2023471116

Email: info@cdi.org

Website: www.cdi.org

Contact: Joe Newman, Director of Communications

The Center for Defense Information (CDI) provides responsible, nonpartisan research and analysis on the social, economic, environmental, political and military components of national and global security, and aims to educate the public and inform policy makers about these issues. The organization is staffed by retired senior government officials and knowledgeable researchers and is directed by Dr Bruce G Blair.

\section{Internship}

Subjects: Weapons proliferation, military spending, military policy, diplomacy and foreign affairs.

Purpose: To support the work of CDl's senior staff while gaining exposure to research, issues and communications related to national security and foreign policy.

Eligibility: There are no eligibility restrictions. Paid internships are available for nationals of the US and legal immigrants.

Level of Study: Unrestricted

Type: Internship

Value: US $\$ 1,000$ per month

Length of Study: $3-5$ months

Study Establishment: CDI

Country of Study: Any country

No. of awards offered: Varies

Application Procedure: Applicants must submit a curriculum vitae, covering letter, brief writing sample, transcript and two letters of recommendation

Closing Date: July 1st for the Autumn, October 15th for the Spring and March 1st for the Summer

Funding: Private

No. of awards given last year: 12

No. of applicants last year: 200

For further information contact:

Center for Defense Information, 1779 Massachusetts Avenue, N.W. Washington, DC, 20036-2109, United States of America

Fax: (1) 2024624559

Email: internships@cdi.org

Contact: Internship Coordinator

\section{World Security Institute Internship}

Subjects: Policy issues, including weapons proliferation, military spending and reform, diplomacy and foreign affairs, small aims trade, terrorism, missile defense and space weaponization.

Purpose: To support work of one of the World Security Institute's four divisions: the Center of Defense Information, Azimuth Media, International Media, or International Programs.
Eligibility: Open to recent graduates, graduate students, and highly qualified undergraduates with a strong interest in military policy, national security, foreign affairs, and related public policy issues who are willing to undertake some small administrative tasks. Although course work in these areas is not required, strong writing capabilities, prior experience in CDI's issue areas, and solid computer skills are appreciated. U.S. citizenship is not required.

Level of Study: Postgraduate

Type: Internship

Value: US $\$ 1,000$ per month unless otherwise noted in the internship descriptions. In some cases, by pre-arrangement, interns may earn academic credit

Length of Study: 1 year

Frequency: Annual

Study Establishment: World Security Institute

No. of awards offered: 18

Closing Date: Please check website

No. of awards given last year: 16

\section{CENTER FOR ECONOMIC RESEARCH \& GRADUATE EDUCATION - ECONOMICS INSTITUTE (CERGE-EI)}

\author{
P.O. Box 882, Politických vězňů 936/7, 11121 Praha 1, \\ Czech Republic \\ Tel: (42) (+420) 224005 123, (+420) 224005250 \\ Fax: (42) (+420) 224005 333, (+420) 224005444 \\ Email: office@cerge-ei.cz, phd@cerge-ei.cz \\ Website: www.cerge-ei.cz/
}

CERGE-EI, a joint workplace of Charles University in Prague and the Czech Academy of Sciences, is dedicated to excellence and innovation in economics research and education. Aiming to expand the pool of elite economists to serve the public interest, CERGE-EI provides a US-style, fully-funded graduate education in English and tuition based MA in Applied Economics program.

\section{CERGE-EI PhD Scholarships in Economics for International Students in Czech Republic}

Subjects: Scholarships are provided in the field of Economics at Center for Economic Research \& Graduate Education - Economics Institute (CERGE-EI). Scholarships cover two years of coursework leading to an MA in Economics degree, as well as the subsequent 2-3 years of supervised dissertation research. Main research areas: microeconomics, macroeconomics, econometrics, empirical economics, public policy.

Purpose: To support talented and motivated students in PhD studies. Eligibility: A Master's degree or equivalent (or expectation to complete a Master's degree by June of the application year) is the best credential for admission. Strong background in mathematics is an advantage. Sufficient proficiency in English to read, write and fully understand $\mathrm{PhD}$-level study material is necessary. Previous education in economics is welcomed, but not required.

Level of Study: Doctorate

Type: Fellowship/Scholarship

Value: The award includes: 1. free application (no application fee).

2. tuition waiver for the entire duration of studies (tuition is otherwise up to $\$ 16,400$ annually for the first 2 years of the $\mathrm{PhD}$ program). 3 . performance-based scholarships to cover living costs (typically US $\$ 5,000$ to US $\$ 10,000$ annually). 4. in addition, most fourth-year students receive an Advanced Student Fellowship, such as the Teaching Fellowship ( $\$ 2,400$ per course taught). 5. full health insurance and residence permit fee coverage for 1 st-4th year full-time students. 6. accommodation stipend (eligible under Charles University) to help cover living expenses. 7 . other benefits such as a subsidy to cover Prague transportation costs

Length of Study: 2 years of master's level coursework $+2-3$ years of supervised dissertation research

Frequency: Annual

Study Establishment: Center for Economic Research \& Graduate

Education - Economics Institute (CERGE-EI)

Country of Study: Czech Republic

No. of awards offered: Up to 30 (varies from year to year) 
Application Procedure: 1. Fill out the application form. 2. Upload the following documents:- Curriculum Vitae- Statement of motivationVerified copies of your Bachelor and Master Diplomas and TranscriptsAdditional materials (TOEFL, IELTS, GRE and other certificates) - not required 3. Ask two referees to fill in the online letters of recommendation. For more information visit website. Only applications including all above mentioned documents are eligible for evaluation. Please fill out the online application and upload requested documents here: http://www.cerge-ei.cz/phd-admissions/phd-how-to-apply.

Alternatively, the requested documents can be sent in hard copy to: Closing Date: April 30th

Funding: Foundation, government

Contributor: Center for Economic Research \& Graduate Education, Economics Institute (CERGE-EI) and CERGE-El Foundation

No. of awards given last year: 30

No. of applicants last year: 279

Additional Information: Students with background in economics, mathematics, international relations, physics, computer science, engineering, law, business, sociology, agriculture, and other related fields are eligible to apply for the scholarship.

For further information contact:

P.O. Box 882, Politických vězňů 936/7, 111 21, Praha 1, Czech Republic

Contact: CERGE-EI

\section{MA in Applied Economics Program Scholarships}

Subjects: Scholarships are given in the form of tuition discounts for exceptionally well-prepared applicants, based on a complete application package (no special procedure to apply for a scholarship). Purpose: To support talented and motivated students during their studies.

Eligibility: BA degree.

Level of Study: Graduate

Type: Scholarship

Value: For detailed information, visit website: www.cerge-ei.cz/

masters-in-applied-economics

Length of Study: 1 year of course studies

Frequency: Annual

Study Establishment: Center for Economic Research \& Graduate

Education - Economics Institute (CERGE-EI)

Country of Study: Czech Republic

No. of awards offered: Up to 10

Closing Date: March 31st. However, we strongly recommend submission of application materials as early as possible to smooth the application process

Funding: Foundation

Contributor: Center for Economic Research \& Graduate Education, Economics Institute (CERGE-EI) and CERGE-EI Foundation

No. of awards given last year: 6

No. of applicants last year: 27

Additional Information: Students with background in economics, mathematics, international relations, physics, computer science, engineering, law, business, sociology and other related fields are eligible to apply for the scholarship.

For further information contact:

CERGE-EI, MA in Applied Economics Program, Politických vìzòù 936/ 7, Praha 1, 111 21, Czech Republic Contact: JOHANA HERMANKOVA, Phd Admissions and Development Coordinator

\section{CENTER FOR HELLENIC STUDIES}

3100 Whitehaven Street NW, Washington, DC, 20008, United States of America

Tel: (1) 2027454400

Fax: (1) 2023328688

Email: fellowships@chs.harvard.edu

Website: http://chs.harvard.edu

Contact: Lanah Koelle, Programs Coordinator

The Center for Hellenic Studies (Trustees for Harvard University) offers residential and non-residential fellowships for professional scholars in ancient Greek studies.

\section{Center for Hellenic Studies and Deutshes Archaologisches Institut Joint Fellowships}

Subjects: Ancient Greek studies including archaeology, art history, epigraphy, history and interdisciplinary research.

Purpose: To encourage and support scholarship of the highest quality on ancient Greek civilization.

Eligibility: Open to scholars and teachers of ancient Greek studies with a PhD degree or equivalent qualification and some published work.

Level of Study: Postgraduate

Type: Fellowship

Value: The stipend consists of two different parts from the DAI and the CHS: $€ 7,500$, distributed in monthly installments during their stay in the BRD, and a stipend of $\$ 17,000$, paid in a lump sum at the beginning of their term in the US. Fellows will also receive health insurance, housing, travel to and from the DAI and $\mathrm{CHS}$, and a fund for research expenses

Length of Study: 9 months from September to May, non-renewable Frequency: Annual

Study Establishment: The Center for Hellenic studies, Washington DC and Deutsches Archaologisches Institut, Berlin

Country of Study: United States of America or Germany

No. of awards offered: 2

Application Procedure: Application must submit an application form a curriculum vitae, a description of the research project, publication samples, and three letters of recommendation. Enquiries about eligibility and early applications are encouraged.

Closing Date: October 15th

Funding: Private

No. of awards given last year: 2

No. of applicants last year: 33

\section{Center for Hellenic Studies Fellowships}

Subjects: Ancient Greek studies including archaeology, art history, epigraphy, history, literary criticism, philology, pedagogical applications and interdisciplinary research.

Purpose: To provide selected classics scholars an academic term or less free of other responsibilities to work on a publishable project. To support collaborative proposals and proposals that use advanced information technology in the study of the ancient Greek world. Eligibility: Open to scholars and teachers of Ancient Greek studies with a PhD degree or equivalent qualification and some published work.

Level of Study: Postdoctorate

Type: Fellowship

Value: Up to US $\$ 17,000$, plus private living quarters and a study at the Center building. Limited funds up to US $\$ 1,000$ for research expenses and research related travel expenses are available Length of Study: Up to 4.5 months from September to January or January to May

Frequency: Annual

Study Establishment: The Center for Hellenic Studies, Washington, DC

Country of Study: United States of America

Application Procedure: Applicants must submit an application form a curriculum vitae, a description of the research project, publication samples and three letters of recommendation. Enquiries about eligibility and early applications are encouraged.

Closing Date: October

Funding: Private

No. of awards given last year: 14 semester residential fellowships No. of applicants last year: 91

\section{CENTER FOR PHILOSOPHY OF RELIGION}

418 Malloy Hall, University of Notre Dame, Notre Dame, IN 46556, United States of America Tel: (1) 5746317339

Email: cpreligion@nd.edu, philreligion@nd.edu Website: www.nd.edu/ cprelig

The Center for Philosophy of Religion at the University of Notre Dame was established in 1976 in order to promote, support and disseminate scholarly work in the philosophy of religion and Christian philosophy. 
The center aims to promote work concerned with the traditional topics and questions that fall under the rubric of the philosophy of religion: the theistic proofs, the rationality of belief in God, the problem of evil, the nature of religious language and the like. At least as important, however, is the Center's effort to support and encourage the development and exploration of specifically Christian and theistic philosophy, the sort of philosophy which takes Christianity (or, more broadly, theism) for granted and then proceeds to work on philosophical questions and problems from that perspective. As one of the world's leading Catholic institution, the University of Notre Dame provides an ideal home for such work.

\section{The Alvin Plantinga Fellowship}

Subjects: Philosophy of religion.

Purpose: To provide time for reflection and writing to a distinguished senior scholar whose work is in the forefront of current research in the philosophy of religion and Christian philosophy.

Eligibility: Open to the senior scholar whose work is in the forefront of current research in the philosophy of religion and Christian philosophy. Level of Study: Research

Type: Stipendiary

Value: $\$ 60,000$

Frequency: Annual

No. of awards offered: 1

Application Procedure: Applications should include a complete curriculum vitae, three letters of recommendation, a statement of no more than three pages describing the project and one published or unpublished paper.

Closing Date: February 1st

Contributor: Center's endowment and College of Arts and Letters at Notre Dame

No. of awards given last year: 1

No. of applicants last year: 15

Additional Information: Please check at http://philreligion.nd.edu/ center-fellowships/ for further details.

\section{Center for Philosophy of Religion's Postdoctoral \\ Fellowships}

Subjects: Philosophy of religion.

Purpose: To support those whose tenure at the Center would allow them to grow and make progress in the Center's areas of interest and subsequently disseminate and expand such work through their own teaching and writing.

Eligibility: Open to those whose tenure at the Center would allow them to grow and make progress in the Center's areas of interest.

Level of Study: Postdoctorate

Type: Fellowship

Value: The Alvin Plantinga Fellowship $(\$ 60,000)$, awarded to a distinguished senior scholar; up to two Research Fellowships ( $\$ 40,000-50,000$, depending on rank); the Frederick J. Crosson Fellowship $(\$ 45,000)$ reserved for foreign scholars and those outside the field of philosophy; and one Visiting Graduate Fellowship $(\$ 20,000)$ awarded to a graduate student in philosophy with research interests in the philosophy of religion. All fellows will receive up to $\$ 2,000$ reimbursement for moving expenses, as well as up to $\$ 2,000$ for research-related expenses.

Frequency: Annual

No. of awards offered: 5

Application Procedure: Applications should include a complete curriculum vitae, three letters of recommendation, a statement of no more than three pages describing the project and one published or unpublished paper.

Closing Date: Please check website

Contributor: Center's endowment and College of Arts and Letters at Notre Dame

No. of awards given last year: 2

No. of applicants last year: 50

Additional Information: Please see web site for more details.

\section{Center for Philosophy of Religion's Visiting Graduate Fellowship}

Subjects: Philosophy of religion.

Purpose: To support research in philosophy of religion or Christian philosophy. For a philosophy graduate student from another institution who has serious research interests in the philosophy of religion.
Eligibility: Applicant must be a graduate.

Level of Study: Graduate

Type: Fellowship

Value: $\$ 20,000$

Frequency: Annual

No. of awards offered: 1

Application Procedure: Applications should include a complete curriculum vitae, three letters of recommendation, a statement of no more than three pages describing the project and one published or unpublished paper.

Closing Date: February

Contributor: Center's endowment and College of Arts and Letters at Notre Dame

No. of awards given last year: 2

No. of applicants last year: 10

Additional Information: Please see web site for more details.

\section{The Frederick J. Crosson Fellowship}

Subjects: Philosophy of religion.

Purpose: To support a foreign scholar (especially one outside the Anglo-American philosophical community) or to a scholar outside the field of philosophy (e.g. a theologian).

Eligibility: See the organization website

Level of Study: Research

Type: Fellowship

Value: $\$ 45,000$

Length of Study: 1 year

Frequency: Annual

No. of awards offered: 1

Application Procedure: Applications should include a complete curriculum vitae, three letters of recommendation, a statement of no more than three pages describing the project and one published or unpublished paper.

Closing Date: February 1st

Contributor: Center's endowment and College of Arts and Letters at Notre Dame

No. of awards given last year: 1

No. of applicants last year: 12

Additional Information: Please check at http://philreligion.nd.edu/ center-fellowships/ for further details.

\section{CENTRAL ASIA RESEARCH AND TRAINING INITIATIVE (CARTI)}

Open Society Foundations, International Higher Education Support Program, Central Asia and Caucasus Research and Training Initiative, Október 6. u.12, Budapest, 1051, Hungary

$$
\begin{aligned}
& \text { Tel: (36) } 18823854 \\
& \text { Fax: (36) } 18823112 \\
& \text { Email: carti@osi.hu }
\end{aligned}
$$

Website: www.soros.org

Contact: Oleksandr Shtokvych, Senior Program Manager

Central Asia Research and Training Initiative (CARTI) is a regional higher education support programme of the Open Society Institute, a private operating and grantmaking foundation. CARTI promotes the development of indigenous capacities for original scholarly and academic work and internationalization of scholarship in the region of Central Asia including, but not limited to, the post-Soviet states of Central Asia and Mongolia.

\section{CARTI Junior Fellowships}

Subjects: Humanities and social sciences.

Purpose: To support young individuals in early stages of their formal Doctoral studies (such as aspirantura) and focus on development of ideas and skills for high-quality research work.

Eligibility: Open to candidates holding a Master's degree or equivalent and formally registered at a Doctoral studies programme (PhD or equivalent programme) from Afghanistan, Kazakhstan, Mongolia, Tajikistan, Turkmenistan or Uzbekistan.

Level of Study: Doctorate

Type: Fellowships

Value: Varies

Length of Study: Up to 2 years

Frequency: Annual 
Application Procedure: Applicants can download the application form from the website.

Closing Date: November 1st (online application)

Additional Information: The programme is open to citizens who are also residents of Afghanistan, Kazakhstan, Kyrgyzstan, Mongolia,

Tajikistan, Turkmenistan or Uzbekistan.

\section{CENTRAL QUEENSLAND UNIVERSITY}

\author{
Building 5 Bruce Highway, Rockhampton, QLD 4702, \\ Australia
}

Tel: (61) 749309000

Fax: (61) 749232100

Email: research-enquiries $@$ cqu.edu.au Website: www.cqu.edu.au

The Central Queensland University (CQU) is committed to excellence in research and innovation with a particular emphasis on issues that affect the region. CQU achieves relevance in its research goals through linkages with industry, business, government and the community and through collaboration with national and international researchers and research networks. CQU provides a range of exciting and relevant research opportunities for Masters and PhD candidates and is committed to excellence and quality in the research training experience of its candidates.

\section{CQ University Australia Postgraduate Research Award}

Subjects: All subjects.

Purpose: To support the research higher degree programs of Masters and PhD.

Eligibility: Open to international residents from any country apart from New Zealand who have first class honours or equivalent.

Level of Study: Graduate, Postgraduate, Research

Type: Research award

Value: $\$ 25,849$

Length of Study: 2 years (Masters Candidates) or 3 years (Doctoral Candidates)

Frequency: Annual

Study Establishment: Central Queensland University

Country of Study: Australia

No. of awards offered: 7

Application Procedure: Check website for further details.

Closing Date: April 17th

Funding: Government

Additional Information: This scholarship is paid fortnightly for the period of up to 2 years (Masters) or up to 3 years (doctorate). Open for applications from July 1st. Please check at www.cqu.edu.au/coursesand-programs/scholarships for further details.

\section{For further information contact:}

Office of Research, Building 32, CQUniversity, Rockhampton, QLD 4702, Australia

Tel: (61) 0749232602

Fax: (61) 0749232600

Contact: Kerne Thompson, Executive Office

Full-Fee International Excellence Research Scholarships

Subjects: Scholarships are awarded to pursue Doctor of Philosophy at CQUniversity.

Purpose: Central Queensland University is currently accepting applications for International Excellence Research Scholarships who are commencing a Doctor of Philosophy at CQUniversity, on or before 1 July 2018.

Eligibility: International students are eligible to apply for this scholarship.

Level of Study: Doctorate

Value: The Scholarship will pay the candidate's annual tuition fees for up to three EFTSL (three full-time equivalent years). The Scholarship will not cover overseas student health cover, living allowances, travel expenses, thesis expenses, the cost of English language testing, tuition fees for bridging programs or ELICOS programs, or project expenses, including the purchase of equipment or other direct research costs

Study Establishment: Scholarships are awarded to pursue Doctor of Philosophy at CQUniversity
Country of Study: Australia

No. of awards offered: CQUniversity will offer the equivalent of up to 12 full-fee Scholarships in 2017-18

Application Procedure: See the website.

Closing Date: Scholarship is open for the year 2018

Additional Information: For more details please browse the website http://scholarship-positions.com/international-excellence-researchscholarships-cq-university-australia/2017/12/12/.

\section{CENTRE FOR ASIA-PACIFIC INITIATIVES (CAPI)}

Sedgewick Building, Room C128, University of Victoria, PO Box 1700, STN CSC, Victoria, BC, V8W 2Y2, Canada

Tel: (1) 2507217020

Fax: (1) 2507213107

Email: capi@uvic.ca

Website: www.capi.uvic.ca

Contact: Helen Lansdowne, Associate Director

The Centre for Asia-Pacific Initiatives (CAPI) was established in 1987 as an important element of the University of Victoria's (Canada) plan to expand and strengthen its links with universities and other institutions in the Asia Pacific region, especially with China, Japan, Southeast Asia, Korea and the developing island states of the Southwest Pacific.

\section{CAPI Student Fellowship for Thesis Research}

Subjects: Languages and research on the Asia-Pacific region.

Purpose: To encourage excellence in research and in the study of languages and research of the Asia-Pacific region.

Eligibility: Open to any student enroled at the University of Victoria who are working towards a Master's degree or PhD.

Level of Study: Research, Postgraduate, Biannual

Type: Fellowships

Value: Canadian $\$ 2,500$

Length of Study: 1 year

Frequency: Annual

Study Establishment: Centre for Asia-Pacific Initiatives

Application Procedure: Applicants must submit their curriculum vitae, a 2-page description of the proposed research project and activities, plus a letter of support from the faculty supervisor. Applications must be submitted electronically to capi@uvic.ca. Closing Date: March 15th

No. of awards given last year: 4

Additional Information: Please check at www.capi.uvic.ca/ opportunities/capi-student-fellowship-asia-pacific for further details.

\section{CENTRE FOR CHINESE STUDIES (CCS)}

Centre for Chinese Studies, Private Bag X1, Matieland, 7602, South Africa

Tel: (27) 218082840

Fax: (27) 218082841

Email: ccsinfo@sun.ac.za

Website: http://www.ccs.org.za/?page_id = 8

The Centre for Chinese Studies (CCS), at Stellenbosch University, serves as the most prominent and high quality point of reference for the study of China and East Asia on the African continent. Our policyrelevant analysis is non-partisan and based on academic standards. The Centre also conducts relevant commissioned analysis of Chinarelated research for government, business, academia and NGO communities.

\section{Postdoctoral Research Fellowship in East Asian (Chinese) and African Studies}

Subjects: The Centre for Chinese Studies (CCS) serves as the most prominent and high-quality point of reference for the study of China and East Asia on the African continent. Their policy-relevant analysis is non-partisan and based on academic standards.

Eligibility: Candidates must have a doctoral degree, obtained in the past 5 years, in a discipline relevant to CCS research themes, preferably with a focus on East Asia (specifically China) and Africa. The Centre for Chinese Studies particularly encourages applications 
from South African nationals with strong academic credentials, especially individuals from previously disadvantaged groups.

Level of Study: Postdoctorate

Value: The value of annual grant is R216,000

Country of Study: South Africa

No. of awards offered: There is a postdoctoral research fellowship available

Application Procedure: Please submit via email a cover letter stating your research interests and career objectives and how this postdoctoral position will advance them, along with a curriculum vitae and a list of publications by post or by email to ranthony@sun.ac.za.

Closing Date: August 31st

Funding: International Office

\section{CENTRE FOR INTERNATIONAL MOBILITY (CIMO)}

P.B. 343, Hakaniemenranta 6, Helsinki, FI-00531, Finland Tel: (358) 295338500,97531123

Fax: (358) 97531122

Website: www.cimo.fi/english

CIMO promotes international cooperation and mobility with specific emphasis on education, training, working life, culture and young people.

\section{CIMO Fellowships Programme for International Doctoral \\ Students}

Subjects: Fellowships are provided to study any one of the courses offered by a Finnish university in Finland.

Purpose: To promote students and researchers from all countries and from all academic fields to pursue doctoral studies at a Finnish university.

Eligibility: The primary target groups in the CIMO Fellowships programme are such Doctoral level students who will be doing their Doctorate (or Double Doctorate) at a Finnish university. Visiting Doctoral-level students and researchers who are doing their Doctorate degree at some foreign university can also be considered eligible, provided that the motivation letter of the hosting Finnish university department presents exceptionally good grounds for such an application.

Level of Study: Doctorate

Type: Fellowship

Value: The grant is 1,500 euro/month. The grant is personal and is intended to cover for the subsistence costs of the scholarship holder in Finland. Additional support for accommodation will not be paid nor will CIMO pay travel or visa/residence permit expenses. Trips abroad to collect research materials cannot be included in the scholarship period Length of Study: 3-12 months

Country of Study: Finland

Application Procedure: Applications should be submitted on the attached CIMO Fellowships application form, which should be filled in electronically, printed and signed. For detailed information, please visit the website.

Closing Date: There is a rolling deadline. Applications must be submitted at least 5 months before the proposed scholarship period Additional Information: International students (emphasis is given to applicants from Russia, China, India, Chile, Brazil and North America) can apply for the fellowships. The Fellowships period may vary from 3 to 12 months. Visits shorter than 3 months will not be funded.

\section{CENTRE FOR THE HISTORY OF SCIENCE, TECHNOLOGY AND MEDICINE (CHSTM)}

The University of Manchester, Second Floor, Simon Building, Brunswick Street, Manchester, M13 9PL, England

Tel: (44) 01612755850

Fax: (44) 01612755699

Email: chstm@manchester.ac.uk Website: www.manchester.ac.uk/chstm

The Centre for the History of Science, Technology and Medicine (CHSTM) maintains teaching and research programmes of the highest standards. It acts as a focus for the history of science, technology and medicine in the northwest of England. CHSTM houses a Welcome Unit for the History of Medicine and the National Archive for the History of Computing.

\section{AHRC Studentships}

Subjects: History

Purpose: To support students working for their MSc and/or PhD in the history of science, technology and medicine.

Eligibility: Applicant must be a doctorate or post-graduate.

Level of Study: Doctorate, Postgraduate

Type: Studentships and bursaries

Value: See www.chstm.manchester.ac.uk/postgraduate/research/ funding/index.aspx

Length of Study: 1 and/or 3 years

Frequency: Annual

Study Establishment: CHSTM

Country of Study: United Kingdom

Application Procedure: The AHRB deadline is May 1st. In order to ensure completion of paperwork and prompt submission of applications, the CHSTM deadline for AHRB forms is April 12th. We expect to work closely with applicants as they complete the forms, so early contact with CHSTM staff is advisable.

Closing Date: Please check website

Funding: Government

Contributor: Arts and Humanities Research Council

\section{Wellcome Trust Studentships}

Subjects: History, and medicine and surgery.

Purpose: To support applicants whose main interests are in the history of medicine.

Eligibility: Applicant should be a UK/European Economic Area (EEA) national with (or be in your final year and expected to obtain) a first- or upper-second-class honours degree or an equivalent EEA graduate qualification.

Level of Study: Postgraduate, Research, Doctorate, Graduate

Type: Studentships and bursaries

Value: The student's stipend; a set amount to cover conference travel research expenses and, where justified, the cost of overseas fieldwork; and all compulsory university and college fees at the UK/Irish home postgraduate student level

Length of Study: 3 years

Frequency: Annual

Study Establishment: CHSTM

Country of Study: United Kingdom

No. of awards offered: 5

Application Procedure: Applicants must complete the university application form (with two references), the Wellcome Trust Studentship application form and submit a curriculum vitae and samples of written work.

Closing Date: April 2nd

Funding: Foundation

Contributor: Wellcome Trust

Additional Information: Applicants are encouraged to discuss their application informally with Professor Michael Worboys and to submit their applications as soon as possible. Please check website for more details.

\section{CEPT UNIVERSITY}

Kasturbhai Lalbhai Campus, University Road, Vasant Vihar, Navrangpura, Ahmedabad, Gujarat 380009, India Contact: CEPT University

CEPT University, formerly the Centre for Environmental Planning and Technology, is an academic institution located near university area in Ahmedabad, India offering undergraduate and postgraduate programmes in areas of the natural and developed environment of human society and related disciplines.

\section{Full-Tuition Fees Waiver for MPhil/PhD Students}

Subjects: Architecture.

Purpose: Scholarships are available for pursuing MPhil/PhD programme.

Eligibility: Students from India are eligible to apply. 
Level of Study: Doctorate, Postgraduate

Value: The university offers full tuition fees waiver to MPhil/PhD students for their entire term of registration in the program. The university also offers a scholarship (INR 36,700 per month-subject to change) for the first six months (mandatory) of the coursework against teaching assignments (15-20 hours/week) as allocated by the respective faculty

Country of Study: India

Closing Date: April 30th

\section{CERIES (CENTRE DE RECHERCHES ET DINVESTIGATIONS EPIDERMIQUES ET SENSORIELLES)}

20 rue Victor Noir, Neuilly-sur-Seine, 92200, France

Tel: (33) 146434900

Fax: (33) 146434600

Email: contact@ceries.com

Website: www.ceries.com

CERIES (Centre de Recherches et d'Investigations Epidermiques et Sensorielles or Centre for Epidermal and Sensory Research and Investigation) is the healthy skin research centre of Chanel.

\section{CERIES Research Award}

Subjects: The biology and physiology of healthy skin and/or its reactions to environmental factors.

Purpose: To honour a scientific researcher for a fundamental or clinical research project in the field of healthy skin.

Eligibility: There are no eligibility restrictions.

Level of Study: Research

Value: $€ 40,000$

Length of Study: 1 year

Frequency: Annual

Country of Study: Any country

Application Procedure: Applicants must consult the website.

Closing Date: June 1st

Funding: Private

Contributor: Chanel

No. of awards given last year: 1

No. of applicants last year: 26

For further information contact:

Email: chanelrt.award@ruderfinnasia.com

Contact: Claire BERNIN-JUNG / Marie-Hélène LAIR

\section{CERN EUROPEAN ORGANIZATION FOR NUCLEAR RESEARCH}

\author{
$\mathrm{CH}-1211$, Geneva, 23, Switzerland \\ Tel: (41) 227678484 \\ Fax: (41) 227678710 \\ Email: recruitment.service@cern.ch \\ Website: www.cern.ch
}

CERN European Laboratory for Particle Physics is the world's leading laboratory in its field, that being the study of the smallest constituents of matter and of the forces that hold them together. The laboratory's tools are its particle accelerators and detectors, which are among the largest and most complex scientific instruments ever built.

\section{CERN Summer Student Programme}

Subjects: Physics, computing and engineering.

Purpose: To awaken the interest of undergraduates in CERN's activities by offering them hands-on experience during their long summer vacation.

Eligibility: Open to all interested students who have completed at least 3 years of full-time studies at university level.

Value: Travel allowance and a daily stipend

Length of Study: 8-13 weeks

Study Establishment: CERN

Country of Study: Switzerland

Application Procedure: A completed application and curriculum vitae along with 2 references must be submitted to CERN.
Closing Date: January 20th (check with website)

Additional Information: Please check at http://home.web.cern.ch/ students-educators/summer-student-programme for further details.

For further information contact:

CERN Recruitment Services via the e-recruitment system Email: jkrich@umich.edu

\section{CERN Technical Student Programme}

Subjects: Accelerator physics, computing, mathematics, engineering, geotechnics, instrumentation for accelerators and particle physics experiments, low temperature physics and superconductivity, materials science, radiation protection, environmental and safety engineering, solid state, surface physics and ultra-high vacuum.

Purpose: To provide placements for students who are specializing in different technical fields.

Eligibility: Open to applicants attending an educational establishment in a CERN member state and following a full-time course in one of the subjects listed, at university or advanced technical level. Students must be less than 30 years of age at the time of the Selection Committee meeting. Candidates must be nationals of the member states of CERN. Students specializing in theoretical or experimental particle physics are not eligible for the programme.

Value: A monthly living allowance to cover the expenses of a single person in the Geneva area. A health insurance for illnesses and accidents of professional or non-professional nature. Joining expenses (on a lump sum basis)

Length of Study: Appointments can last for 4 to 12 months at CERN during the course of your studies (Bachelor or Master). An extension of up to a maximum of 14 months may be given.

Study Establishment: The European Laboratory for Particle Physics Country of Study: Switzerland

No. of awards offered: Approx. 80-90

Application Procedure: Applications must be made electronically via the website.

Closing Date: March 5th

Funding: Government

No. of awards given last year: Approx. 80-90

No. of applicants last year: Approx. 240

Additional Information: The official languages of CERN are English and French. A good knowledge of at least one of these languages is essential. CERN member states include Austria, Belgium, Bulgaria, the Czech Republic, Denmark, Finland, France, Germany, Greece, Hungary, Italy, the Netherlands, Norway, Poland, Portugal, Slovakia Republic, Spain, Sweden, Switzerland, and the UK. Please check at http://jobs.web.cern.ch/join-us/technical-student-programme for further details.

\section{CERN-Japan Fellowship Programme}

Subjects: LHC data analysis and physics.

Purpose: To support young researchers who are interested in LHC data analysis and physics studies.

Eligibility: Applicants should be nationals or permanent residents of Japan and have a doctorate for applicants in experimental or phenomenological physics and/or accelerator science. Candidates who are currently preparing a PhD are eligible to apply. However, they are expected to have obtained their $\mathrm{PhD}$ by the time they take up their appointment at CERN.

Level of Study: Doctorate

Type: Fellowship

Value: Covers travel expense and insurance coverage

Length of Study: Up to 3 years

Frequency: Annual

Application Procedure: A completed electronic application form

along with a curriculum vitae should be submitted.

Closing Date: December 1st

Contributor: CERN

Additional Information: Please check at http://jobs.web.cern.ch/job/ 10941 for further details.

For further information contact:

Recruitment Service, Human Resource Department, CERN, Geneva 23, $\mathrm{CH}-1211$, Switzerland

Email: recruitment.science@cern.ch 


\section{CHANDIGARH UNIVERSITY}

NH-95 Chandigarh-Ludhiana Highway, Mohali, Punjab, 140413, India Contact: Chandigarh University

A renowned university in India is offering scholarships for brilliant but less privileged students across the globe who have the interest in studying in India.

Chandigarh University Scholarships in India, 2018-2019 Subjects: Scholarships are awarded to study the subjects offered by the university.

Purpose: Chandigarh University offers undergraduate and postgraduate and doctorate courses in various disciplines including Engineering, Management, Computing, Education, Animation and Multimedia, Tourism, Pharma Sciences, Biotechnology, Architecture, Commerce, Legal Studies, Agricultural Science, Media Studies, Liberal Arts and Basic Sciences. It also offers Engineering and Management Programs in collaboration with IBM as well as an MBA in Banking \& Financial Engineering in collaboration with the $\mathrm{ICICI}$ Direct Centre for Financial Learning.

Eligibility: Students outside India, Nepal and Bhutan can apply for these scholarships. Not Required but all academic documents are to be sent to micheal.africa-at-cumail.in for eligibility checking. Not required but the applicant must be able to read, write and understand the English Language.

Level of Study: Doctorate, Postgraduate

Study Establishment: Scholarships are awarded to study the subjects offered by the university

Country of Study: India

No. of awards offered: Our scholarship is a partial one, and it ranges from $15 \%$ to $50 \%$ (maximum) on tuition fee only. Plus free airport pickup to university's campus, Feeding (3 times a day) should the applicant opt for a hostel facility

Application Procedure: Interested students can contact Mr. Michael on micheal.africa-at-cumail.in. The micheal.africa@cumail.in is the official email ID we are using now in terms of scholarship admission and enquiries.

Closing Date: Last week of July

Additional Information: For more details please contact the website http://scholarship-positions.com/chandigarh-university-scholarshipsindia/2018/02/17/.

\section{CHARLES BABBAGE INSTITUTE (CBI)}

211 Andersen Library, University of Minnesota, 222 21st Avenue South, Minneapolis, MN 55455, United States of America

$$
\begin{gathered}
\text { Tel: (1) } 6126245050 \\
\text { Fax: (1) } 6126258054 \\
\text { Email: cbi@umn.edu }
\end{gathered}
$$

Website: www.cbi.umn.edu

The Charles Babbage Institute ( $\mathrm{CBI}$ ) is a research centre dedicated to promoting the study of the history of computing, its impact on society and preserving relevant documentation. $\mathrm{CBI}$ fosters research and writing in the history of computing by providing fellowship support, archival resources and information to scholars, computer scientists and the general public.

\section{Adelle and Erwin Tomash Fellowship in the History of Information Processing}

Subjects: The history of computing and information processing. Purpose: To advance the professional development of historians in the field.

Eligibility: Open to graduate students whose dissertations deal with a historical aspect of information processing. Priority will be given to students who have completed all requirements for the doctoral degree except the research and writing of the dissertation.

Level of Study: Doctorate

Type: Fellowship

Value: US\$14,000

Length of Study: 1 year

Frequency: Annual

Country of Study: Any country

No. of awards offered: 1
Application Procedure: Applicants must send their curriculum vitae, a five page statement and justification of the research problem, and a discussion of methods, research materials and evidence of faculty support for the project. Applicants should also arrange for three letters of reference and certified transcripts of graduate school credits to be sent directly to the Institute.

Closing Date: January 15th

Funding: Private

Additional Information: Please check at www.cbi.umn.edu/ research/tfellowship.html for further details.

For further information contact:

Charles Babbage Institute University of Minnesota 103 Walter Library 117 Pleasant Street, SE, Minneapolis, MN 55455

Tel: 6245050

Fax: 6258054

Email: nels0307@umn.edu

Contact: R. Arvid Nelsen, CBI Archivist

\section{CHARLES DARWIN UNIVERSITY (CDU)}

Charles Darwin University, Ellengowan Drive, Casuarina, NT 0811, Australia

Tel: (61) 0889466666

Fax: (61) 0889466642

Email: scholarships@cdu.edu.au Website: www.cdu.edu.au

The Charles Darwin University (CDU) offers programmes from certificate level to $\mathrm{PhD}$, incorporating the full range of vocational education courses. CDU has a distinctive research profile, reflecting the priorities appropriate to its location. It is a participating member of several CRCs.

\section{ARC Australian Postgraduate Award-Industry}

Subjects: Agriculture, forestry and fishery; arts and humanities; education and teacher training; Engineering; fine and applied arts; medical sciences; natural sciences; recreation, welfare, protective services; social and behavioural sciences.

Purpose: To provide industry-oriented research training and enable postdoctoral researchers to pursue internationally competitive research opportunities in collaboration with industry.

Level of Study: Doctorate, Foundation programme, Research, Master by Research

Type: Scholarship

Value: $\$ 24,653$ per year. Additional benefits include paid sick leave maternity/paternity leave, relocation and a thesis allowance

Length of Study: 2-3 years

Frequency: Annual

Country of Study: Australia

No. of awards offered: Approx. 15-20 per year

Application Procedure: Completion and submission of an application is required, check at www.cdu.edu.au/research/office/applicationkit.html. Closing Date: March 31st

Funding: Government

Contributor: Australian Government

No. of awards given last year: 20

No. of applicants last year: 50

Additional Information: Enquiries and requests for additional information may be directed to the CDU Research Degrees Administration Officer by email: research@cdu.edu.au. Intending international applicants should contact the CDU International Office by email: international@cdu.edu.au. Eligibility of other countries conditional upon meeting eligibility criteria.

For further information contact:

Research Scholarships, Office of Research and Innovation, Charles Darwin University, Ellengowan Drive, Darwin, NT 0909, Australia

\section{International Postgraduate Research Scholarships}

Subjects: Agriculture, forestry and fishery; arts and humanities; education and teacher training; Engineering; fine and applied arts; medical sciences; natural sciences; recreation, welfare, protective services; social and behavioural sciences.

Purpose: To support annual course costs plus the cost of an Overseas Student Health Cover policy. 
Eligibility: International applicants: An Australian bachelor degree with first class honours, or an Australian master degree with a substantial research component, or an equivalent level of academic attainment, and meet Australian international student visa requirements, and meet minimum English entry requirements. Level of Study: Doctorate, Postgraduate, Research, Master by research

Type: Scholarship

Value: Annual course fees plus health cover

Length of Study: 2-3 years

Frequency: Annual

Country of Study: Australia

No. of awards offered: Approx. 2 per year

Application Procedure: Completion and submission of an application: www.cdu.edu.au/research/office/applicationkit.html.

Closing Date: March 31st

Funding: Government

Contributor: Australian Government

No. of awards given last year: 2

No. of applicants last year: 14

Additional Information: Enquiries and requests for additional information may be directed to the CDU Research Degrees Administration Officer by email to research@cdu.edu.au. Intending international applicants should contact the CDU International Office by email to international@cdu.edu.au.

\section{For further information contact:}

Research Scholarships, Office of Research and Innovation, Charles Darwin University, Ellengowan Drive, Darwin, NT 0909, Australia

\section{Vice-Chancellor's International High Achievers \\ Scholarships}

Purpose: Scholarships are available for pursuing undergraduate or postgraduate coursework degree level at Charles Darwin University. Eligibility: Eligible applicants must have demonstrated record of academic excellence and high achievement in previous relevant. Students must maintain satisfactory academic progress in each semester in the degree at CDU.

Level of Study: Graduate, Postgraduate

Type: Scholarship

Value: CDU offers a limited number of 50 per cent and 25 per cent tuition fee scholarships for international students who have a record of academic excellence and high achievement

\section{Country of Study: Australia}

No. of awards offered: Limited number of tuition fee scholarships Application Procedure: Download the Vice-Chancellor's International High Achiever's Scholarship Application Form and submit with application for admission to a degree program at CDU.

Closing Date: Check the website

Additional Information: Applicants should not hold a scholarship from an Australian or foreign sponsoring agency. Students must pay the balance of 50 per cent tuition fees in advance of the commencement of each semester.

\section{CHARLES STURT UNIVERSITY (CSU)}

Charles Sturt University Boorooma Street, Locked Bag 588, Wagga, NSW 2678, Australia

Tel: (61) 263386077

Fax: (61) 0263386001

Email: inquiry@csu.edu.au, research@csu.edu.au Website: www.csu.edu.au

$\mathrm{CSU}$ is one of the leading Australian universities for graduate employment and largest provider in distance education. Utilizing our expertise in distance education, CSU provides educational opportunities to students around the world. Around 36,000 students undertake their choice of study with CSU on one of our campuses, from home, their workplace or anywhere around the globe.

\section{Academic Staff RHD Workload Support Scheme}

Subjects: All subjects

Purpose: To assist academic staff of the University to obtain a research higher degree qualification (Research Masters or PhD) or a research professional doctorate in areas of strategic importance to the institution.

Eligibility: This scheme is open to all academic staff of Charles Stuart University.

Level of Study: Postgraduate, Research

Value: A formal workload allocation during candidature plus, for staff enroled in a CSU RHD program, tuition fees, student resource funds and supervision funds to the Faculty

Frequency: Annual

Application Procedure: Applicants must submit an application form. Closing Date: Please check website

Additional Information: For further information please see the website: www.csu.edu.au/research/support/researchers/funding/ internal/ashdwss.

\section{Australian Postgraduate Awards \\ Subjects: All subjects.}

Purpose: To financially support postgraduate students of exceptional research promise in Master or Doctoral programs at Charles Sturt University.

Eligibility: Awards will only be available to those who are Australian citizens and New Zealand citizens; have been granted permanent resident status by October 31st; have lived in Australia continuously for at least 12 months prior to October 31st; have completed at least 4 years of tertiary education studies at a high level of achievement; have obtained First Class Honours or equivalent results; will undertake a Master's (Honours) or Doctoral degree; are enroling as full-time students or, in exceptional circumstances, be granted approval by CSU for a part-time award; have had their enrolment into the proposed higher degree programme accepted by CSU.

Level of Study: Postgraduate, Research

Type: Award

Value: $\$ 32,500$ per year

Length of Study: 2-3 years

Frequency: Annual

Study Establishment: Charles Sturt University

Country of Study: Australia

Application Procedure: Applicants must submit an application form. Closing Date: October 31st

Funding: Government

Additional Information: Please check at www.csu.edu.au/research/ support/research-students/my-hdr/getting-started/scholarship-opportunities/main-round for further details.

\section{Charles Sturt University Postgraduate Research} Studentships (CSUPRS)

Subjects: All subjects.

Purpose: To support high quality research students in Masters or Doctoral programs at Charles Sturt University.

Eligibility: Open to the candidates who hold or expect to hold, at least a Bachelor degree with upper second class honours or a qualification deemed equivalent from CSU.

Level of Study: Graduate, Research

Type: Studentship

Value: $\$ 22,500$ stipend plus allowances

Frequency: Annual

No. of awards offered: Up to 8

Application Procedure: Scholarship application form can be downloaded from the website. Send in the filled application to the center with original referee report and five copies of their report.

Closing Date: October 30th

Additional Information: Offers of scholarships cannot be made to candidates until their enrolment as Research Higher Degree students has been approved by the Board of Graduate Studies.

Please check at www.csu.edu.au/research/support/researchstudents/my-hdr/getting-started/scholarship-opportunities/main-round for further details.

\section{For further information contact:}

Postgraduate Scholarships, Center for Research \& Graduate Training, Charles Sturt University, Locked Bag 588, Wagga Wagga, NSW 2678, Australia

Tel: (61) 0269334162

Email: pgscholars@csu.edu.au 


\section{Commercialisation Training Grant Scheme}

Subjects: All subjects.

Purpose: Aims to provide Research Higher Degree students with a fully accredited course designed to enhance their professional capacity and skills, and provide commercial application of base concepts developed in research management.

Eligibility: To be eligible to receive a CTS place, a student must: (a) Be an Australian citizen, a New Zealand Citizen or an Australian permanent resident; (b) have completed a minimum of 1-year full time equivalent of their Research Higher Degree. (NOTE: Part-Time Higher Degree students are not eligible to receive the stipend); (c) have the support of their Principal Supervisor; (d) not have previously completed CTS training or training consistent with CTS requirements. Level of Study: Postgraduate, Research

Type: Grant

Value: Maximum Australian $\$ 8,000$

Length of Study: 15 months

Frequency: Annual

Application Procedure: Applicants must submit an application form. Closing Date: March 23rd and July 23rd

\section{International Postgraduate Research Studentships (IPRS)}

Subjects: All subjects.

Purpose: To attract top quality international postgraduate students to areas of research strength in Australian higher education institutions. Eligibility: Applicants should hold, or expect to hold, at least a Bachelor degree with upper second class honours or a qualification deemed equivalent.

Level of Study: Postgraduate, Research

Type: Scholarship

Value: The scholarship will cover tuition fees payable for each year of the course

Length of Study: 2 years for Masters by Research and 3 years for Research Doctorates

Frequency: Annual

Country of Study: Australia

No. of awards offered: Up to 8

Application Procedure: Applicants must submit an application form. Closing Date: October 29th

Funding: Government

Additional Information: Please check at www.csu.edu.au/research/ support/research-students/my-hdr/getting-started/scholarship-opportunities/main-round for further details.

\section{Writing Up Awards - Postgraduate Students \\ Subjects: All subjects.}

Purpose: To improve publication rates by providing a modest income to higher degree by research students following submission of thesis to enable the preparation of articles or books based on their postgraduate thesis.

Eligibility: For Charles Sturt University Masters by research or PhD candidates who either are about to submit a thesis or have just submitted a thesis for examination and have not yet qualified to graduate.

Level of Study: Research, Postgraduate

Type: Award

Value: Maximum Australian $\$ 5,000$

Frequency: Twice a year

Application Procedure: Applicants must submit an application form. Closing Date: March 9th for funding to commence from March 30th Additional Information: This award does not provide financial support to postgraduate student to write their thesis. Please check at www.csu.edu.au/research/support/researchers/funding/internal for further details.

\section{THE CHARLES WALLACE TRUST}

The Charles Wallace Trust, 4 Dorville Crescent, London, W6 OHJ, United Kingdom

Tel: (44) 02087410836

Email: timbutchard@wallace-trusts.org.uk

Website: www.wallace-trusts.org.uk

Contact: Mr Tim Butchard, Secretary

\section{The Charles Wallace Bangladesh Trust - Doctoral} Bursaries

Subjects: The criteria for awarding these grants are a combination of academic excellence and financial need.

Purpose: Awards are granted to individual students already in the UK who are normally in the final year, or anticipating the final year, of their $\mathrm{PhDs}$, and who need additional funding to help them complete their studies.

Eligibility: The Trust is not primarily a hardship fund and all applicants are required to demonstrate academic excellence as well as financial need.

Level of Study: Doctorate

Type: Bursary

Value: $£ 750$ (Maximum)

Frequency: Biannual

Country of Study: United Kingdom

No. of awards offered: Varies

Application Procedure: Applicants must complete the Trust's

Application Form and submit it, either in hard copy or as an email attachment, to the Secretary of the Trust. The application should be accompanied by a supporting letter on headed paper from the applicant's supervisor. Other documents testifying to the applicant's background and achievements to date should be kept to a minimum. Closing Date: May and November

Funding: Trusts

Additional Information: Please check at www.wallace-trusts.org.uk/ cwt bangadesh.html for further details.

\section{The Charles Wallace Bangladesh Trust - Professional Training Bursaries}

Subjects: Disciplines are unrestricted but the trustees reserve the right to assess the usefulness of the training both to Bangladesh and to the individual concerned.

Purpose: Limited financial support to enable mid-career professionals.

Eligibility: Normally aged between 35 and 45 . Preference is given to candidates who have had little or no prior training or experience outside Bangladesh.

Level of Study: Professional development

Type: Bursary

Value: $£ 750$ (Maximum)

Length of Study: The eligible courses must last at least 2 weeks

Frequency: Biannual

Application Procedure: Applicants must complete the Trust's Application Form and submit it, either in hard copy or as an email attachment, to the Secretary of the Trust. The application should be accompanied by a supporting letter on headed paper from the applicant's supervisor. Other documents testifying to the applicant's background and achievements to date should be kept to a minimum Closing Date: November

Funding: Trusts

Additional Information: Please check at www.wallace-trusts.org.uk/ cwt_bangadesh.html for further details.

\section{The Charles Wallace Burma Trust - Postgraduate Student Bursaries}

Purpose: Awards are granted to individual students undertaking, or about to undertake, postgraduate courses in the UK at Master's or Doctoral level and who need additional funding to help them cover the cost of their studies.

Eligibility: Open to residents of Myanmar. Also open to Burmese nationals to pursue postgraduate study in the UK at Masters or

Doctoral level, and who need additional funding to help them cover the cost of their studies.

Level of Study: Postgraduate

Type: Bursary

Value: Our maximum grant is $£ 1,500$, so applicants must have funds from other sources to cover most of their expenses

Frequency: Biannual

Country of Study: United Kingdom

Application Procedure: The trust is not primarily a hardship fund and all applicants are required to demonstrate academic excellence as well as financial need. Applicants must complete the trust's application form and submit it, either in hard copy or as an email attachment, to the Secretary of the Trust. The application should be accompanied by 
a supporting letter on headed paper from the applicant's course leader or supervisor in the UK. Applicants who have not yet commenced their U.K. courses should show written evidence of acceptance, and full details of their sources of finance, as well as a letter of reference from a senior academic source in Burma/Myanmar. Documents testifying to the applicant's background and achievements to date should be kept to a minimum.

Closing Date: May 1st and November 1st

Funding: Trusts

Additional Information: Please check at www.wallace-trusts.org.uk/ cwt burma.html for further details.

\section{The Charles Wallace Burma Trust - Visiting Fellowships}

Subjects: Intended for those holding management posts in the following subject areas: development management and disaster relief; environmental management; governance and human rights law; media production.

Purpose: To enable at least two Burmese professionals to undertake short visits to the UK each year in order to broaden their professional knowledge, skills and contacts. They are not intended to facilitate formal training.

Eligibility: Eligible candidates are Burmese nationals, residing in Burma. They are normally junior or mid-career professionals and practitioners, aged between 30 and 50. Candidates must have a working knowledge of the English language adequate for their requirements. Candidates who have never travelled abroad for study or professional purposes will have a modest advantage in the selection process.

Level of Study: Professional development

Type: Fellowship

Value: An all-inclusive monthly stipend of $£ 1,250$ is offered by the trust, also a return economy air fare. There is no provision for course or bench fees

Length of Study: The duration of a fellowship varies from 4 weeks to a maximum of 3 months

Frequency: Annual

Country of Study: United Kingdom

Application Procedure: The key preliminary step is that candidates identify a U.K.-based partner or host institution, and obtain an invitation letter. Secondly, an application form, acquired from the website of the British Council in Burma (www.britishcouncil.org/ burma), must be completed and submitted as instructed. For further information please contact the British Council's information desk (enquiries@mm.britishcouncil.org) or email the Secretary of the Trust in London (timbutchard@wallace-trusts.org.uk)

Closing Date: Please check website

Funding: Trusts

Additional Information: Please check at www.wallace-trusts.org.uk/ cwt_burma.html for further details.

\section{The Charles Wallace India Trust}

Purpose: The Charles Wallace India Trust (CWIT) gives grants to Indians in the early or middle stages of their careers who are living in India and working or studying in the arts, heritage conservation or the humanities.

Eligibility: The applicant should be an Indian citizen living in India The candidate shouldbe aged between 25 and 38 with a first degree, diploma or professional qualification in their specialization. CWIT prefers applicants with significant working experience

Level of Study: Doctorate, Postdoctorate, Postgraduate, Professional development

Type: Grants and fellowships

Value: Dependent upon award: funding towards arts and heritage conservation; funded fellowships; grants toward short research or professional visits; grants towards Doctoral study costs

Frequency: Annual

Country of Study: United Kingdom

Application Procedure: See British Council website for more details: www.britishcouncil.org/india-scholarships-cwit.htm. For further information please email at cwit@in.britishcouncil.org.

Closing Date: December 1st and refer to website as deadlines differ Funding: Trusts

Additional Information: Please check at www.wallace-trusts.org.uk/ cwt_india.html for further details.

\section{The Charles Wallace Pakistan Trust - Open Visiting Fellowships}

Purpose: To enable Pakistani men and women to undertake short visits to the UK in order to broaden their professional knowledge, skills, and contacts.

Eligibility: Eligible candidates are Pakistani nationals, residing in Pakistan. They are normally junior or mid-career professionals or academics aged between 30 and 50, working in the following disciplines: humanities, arts, and creative industries; social sciences and social development; the environmental and health sciences. Candidates who have never travelled abroad for study or professional purposes will have a modest advantage in the selection process. Level of Study: Doctorate, Professional development

Type: Fellowship

Value: The fellowships will normally take the form of two principal activities: professional familiarization and interaction and study and research. An all-inclusive monthly stipend of $£ 1,250$ is offered by the trust, also a return economy air fare.

Length of Study: The duration of a fellowship varies from 3 weeks to a maximum of 3 months

Frequency: Annual

No. of awards offered: 15

Application Procedure: The key preliminary step is that candidates identify a U.K.-based partner or host institutions, and obtain an invitation letter from them. Secondly, an application form, downloaded from the website of the British Council in Pakistan (www.britishcouncil. org.pk), must be completed and submitted as instructed in advance of the British Council's annual deadline. Interviews of short-listed candidates will take place in Islamabad, Lahore and Karachi in April of each year.

Closing Date: Mid-March

Funding: Trusts

Additional Information: Please check at www.wallace-trusts.org.uk/ cwt_pakistan.html for further details.

\section{The Charles Wallace Pakistan Trust - Reserved Visiting Fellowships}

Purpose: The fellowships enable Pakistani academics and professionals to undertake short working visits to these institutions with the aim of broadening their professional knowledge, skills and contacts. Level of Study: Postgraduate

Type: Fellowship

Value: An all-inclusive monthly stipend of $£ 1,250$ is offered by the

Trust, together with return economy air fares, but there is no provision for course or bench fees.

Length of Study: The duration of a fellowship varies from 3 weeks to a maximum of 3 months

Frequency: Annual

Study Establishment: University of London, Oxford University, Edinburgh University

Country of Study: United Kingdom

No. of awards offered: 4

Application Procedure: The selection criteria adopted by these partner institutions vary and each has its own application requirements. Common to all is the need for a full curriculum vitae, and a clear statement of what the applicant proposes to achieve during the fellowship period. In every case, the selection is made by the host institution but must be endorsed by the British Council in Pakistan and by the Charles Wallace Pakistan Trust in the UK.

Closing Date: Please check website

Funding: Trusts

Additional Information: Please check at www.wallace-trusts.org.uk/ cwt_pakistan.html for further details.

\section{The Charles Wallace Pakistan Trust - Visiting Artists}

Subjects: Currently, these are mainly drawn from the visual arts, but other art forms also qualify for support.

Purpose: Enables arts practitioners from Pakistan to spend time in the UK on arts residencies or for training and familiarization purposes. Eligibility: Charles Wallace Open Visiting Fellowships, offered under a partnership between the British Council in Pakistan and the Charles Wallace Pakistan Trust in the United Kingdom, enable Pakistani men and women to undertake short visits to the UK in order to broaden their professional knowledge, skills, and contacts. Eligible candidates 
are Pakistani nationals, residing in Pakistan. They are normally junior or mid-career professionals or academics aged between 30 and 50 Level of Study: Professional development

Type: Grant

Value: An all-inclusive monthly stipend of $£ 1,250$ will be paid by the trust, also a return economy air fare

Length of Study: The duration of stay in the UK can vary from

3 weeks to 3 months

Frequency: Annual

Study Establishment: The Prince's School of Traditional Arts, Gasworks

Application Procedure: Apply directly to the Trust's Secretary (timbutchard@wallace-trusts.org.uk).

Closing Date: Please check website

Funding: Trusts

Additional Information: Please check at www.wallace-trusts.org.uk/ cwt_pakistan.html for further details.

\section{The Charles Wallace Pakistan Trust Doctoral Bursaries}

Subjects: The disciplines eligible for support are restricted to the following: The humanities, arts, and creative industries The social sciences and social development The environmental and health sciences.

Purpose: Twice a year, in June and December, awards are granted to individual students already in the UK who are normally in the final year, or anticipating the final year, of their PhDs, and who need additional funding to help them complete their studies.

Eligibility: All applicants are required to demonstrate academic excellence as well as financial need.

Level of Study: Doctorate

Type: Bursary

Value: Our maximum grant is $£ 1,000$, so applicants must have funds from other sources to cater for most of their needs

Frequency: Biannual

Country of Study: United Kingdom

Application Procedure: Applicants must complete CWPT's application form and submit it, either in hard copy or as an email attachment to the Secretary of the Trust. The application should be accompanied by a supporting letter on headed paper from the applicant's supervisor. Other documents testifying to the applicant's background and achievements to date should be kept to a minimum.

Closing Date: Two annual deadlines are the end of the first week in May and the end of the first week in November

Funding: Trusts

Additional Information: Please check at www.wallace-trusts.org.uk/ cwt_pakistan.html for further details.

\section{THE CHARLIE TROTTER CULINARY EDUCATION FOUNDATION}

40 E. Chicago Avenue, Suite 418, Chicago, IL 60611, United States of America

Tel: (1) 3126009724

Fax: (1) 7732486088

Email: info@charlietrotters.com

Website: www.charlietrotters.com/about/foundation.asp

Charlie Trotter's is regarded as one of the finest restaurants in the world, dedicated to excellence in the culinary arts. It has been instrumental in establishing new standards for fine dining. Its main goal is to educate and expose the youth to the great culinary arts in as many ways as possible. The Charlie Trotter Culinary Education Foundation, a non-profit organization, has been established to promote culinary arts among youth. The foundation is involved in awarding scholarships to students who are seeking careers in the culinary arts and working with Chicago-area youth to promote the enthusiastic quest for education as well as an interest in the cooking and food

\section{Charlie Trotter's Culinary Education Foundation Culinary Study Scholarship \\ Subjects: Cooking. \\ Eligibility: Open to an Illinois resident at the time of application. \\ Level of Study: Professional development \\ Type: Scholarship}

Value: US $\$ 5,000$ cash scholarship for a pre-enroled student Length of Study: 1 year

Frequency: Annual

Country of Study: United States of America

No. of awards offered: 1

Application Procedure: Check website for further details.

Closing Date: March 1st

Funding: Private, foundation

Contributor: Charlie Trotter's

Additional Information: Please check website for more details.

For further information contact:

The Culinary Trust Scholarship Program P.O. Box 273, New York, NY 10013, United States of America

Tel: (1) 6462246989

Email: cholarships@theculinarytrust.com

Website: www.theculinarytrust.org

Contact: Amy Blackburn, Director of Administration

\section{CIAT CHARTERED INSTITUTE OF ARCHITECTURAL TECHNOLOGISTS}

\author{
397 City Road, London, EC1V 1NH, United Kingdom \\ Tel: (44) 02072782206 \\ Fax: (44) 02078373194 \\ Email: careers@ciat.org.uk \\ Website: www.ciat.org.uk/en \\ Contact: Jack Wilson, Education and Membership Administrator
}

The Chartered Institute of Architectural Technologists (CIAT) is the lead qualifying body for Architectural Technology and represents those practising and studying within the discipline. CIAT qualifies Chartered Architectural Technologists, MCIAT, and professionally qualified Architectural Technicians, TCIAT.

\section{CIAT John Newey Education Foundation}

Subjects: Architecture, building and planning and engineering Eligibility: Applicants must be members of CIAT, except chartered, and studying in full or part-time education on an approved course and facing hardship.

Level of Study: Graduate, Foundation programme, Postgraduate

Type: Bursary

Value: $£ 500$ each

Frequency: Annual

No. of awards offered: 2

Application Procedure: Supporting testimony from the course tutor with an endorsing signature from the Head of Department.

Closing Date: March 31st

Funding: Foundation

Additional Information: Please check at www.ciat.org.uk/en/awards/ student-awards/John_Newey_Education_Foundation/index.cfm for further details.

\section{CHEMICAL HERITAGE FOUNDATION (CHF)}

\author{
315 Chestnut Street, Philadelphia, PA 19106, \\ United States of America \\ Tel: (1) 2159252222 \\ Fax: (1) 2159251954 \\ Email: info@chemheritage.org \\ Website: www.chemheritage.org \\ Contact: Ashley Augustyniak, Fellowship Co-ordinator
}

The Beckman Center for the History of Chemistry is the historical unit of the Chemical Heritage Foundation (CHF), which is located in Philadelphia. The Center is devoted to preserving, making known and applying the history of the chemical and molecular science technologies and associated industries.

\section{Dissertation Fellowships}

Subjects: History of chemical sciences, technologies and industries. Purpose: To fund graduate students at the PhD dissertation stage who are pursuing research in the chemical histories. 
Eligibility: Open to scholars pursuing research on the history of the chemical sciences and must be a graduate student at the PhD dissertation stage.

Level of Study: Postdoctorate, Doctorate

Type: Fellowship

Value: US\$26,000

Length of Study: 9 months

Frequency: Annual

Study Establishment: Chemical Heritage Foundation

Country of Study: United States of America

Application Procedure: Applicants must apply online at the website.

Closing Date: February 15th

Funding: Private

No. of awards given last year: 4

Additional Information: Please check at www.chemheritage.org/ research/beckman-center/beckman-center-fellowships/long-termfellowships.aspx for further details.

\section{Glenn E and Barbara Hodsdon Ullyot Scholarship}

Subjects: The history of science.

Purpose: To advance understanding of the importance of the chemical sciences to the public's welfare.

Eligibility: Open to writers, journalists, educators and historians.

Level of Study: Postdoctorate, Doctorate, Postgraduate

Type: Scholarship

Value: A stipend for the 2 months is $\$ 6,000$ paid in biweekly installments

Length of Study: A minimum of 2 months

Frequency: Annual

Study Establishment: Chemical Heritage Foundation

Country of Study: United States of America

No. of awards offered: 1

Application Procedure: Applicants must apply online at the website.

Closing Date: February 15th

Funding: Private

No. of awards given last year: 1

Additional Information: Applications are invited from scholars,

science writers and journalists. Please check at www.chemheritage. org/research/beckman-center/beckman-center-fellowships/shortterm-fellowships.aspx for further details.

\section{Postdoctoral Fellowship}

Subjects: History of chemical sciences, technologies and industries. Purpose: To support historical research by $\mathrm{PhD}$ scholars focused on history of chemistry, technology and industry.

Eligibility: Open to a scholar with a PhD who will carry out historical research on the history of chemistry.

Level of Study: Postdoctorate

Type: Fellowship

Value: US $\$ 45,000$

Length of Study: 9 months

Frequency: Annual

Study Establishment: Chemical Heritage Foundation

Country of Study: United States of America

Application Procedure: Applicants must apply online at the website. Closing Date: January 15th

Funding: Private

Additional Information: Please check at www.chemheritage.org/ research/beckman-center/beckman-center-fellowships/long-termfellowships.aspx for further details.

\section{Research Travel Grants}

Purpose: To offer grants to assist with travel and accommodation expenses for researchers who wish to use its primary research collections for short-term research.

Eligibility: Travel grant applicants must reside more than 75 miles from Philadelphia to be eligible. No more than one travel grant per person per fiscal year (July 1st to June 30th) can be awarded. Grants must be taken within 1 year of the award or the grantee must request an extension or reapply.

Type: Grant

Value: Travel grants are $\$ 750$ per week and are intended to help defray the costs of travel and accommodation

Application Procedure: There is no deadline for travel grant applications. Travel grant applications can be submitted at any time and are assessed by an internal CHF review committee. Please allow for 2 weeks after submission for notification of the committee's decision.

Closing Date: No fixed deadlines. Travel grant applications can be submitted at any time and are assessed by an internal CHF review committee that takes 2 weeks after submission for notification of its decision

Additional Information: Travel grant applications must be submitted electronically, as Word or PDF files, to travelgrants@chemheritage. org. Please check at www.chemheritage.org/research/beckman-center/beckman-center-fellowships/travel-grants.aspx for further details.

\section{Short Term Fellowship}

Subjects: History of the chemical sciences and technologies.

Purpose: To fund scholars who are pursuing research on history of the chemical and molecular sciences, technologies, and industries. Eligibility: Open to scholars pursuing research on the history of the chemical sciences.

Level of Study: Doctorate, Postdoctorate

Type: Fellowship

Value: US $\$ 3,000$ per month

Length of Study: 1-4 months

Frequency: Annual

Study Establishment: Chemical Heritage Foundation

Application Procedure: Applicants must apply online at the website. Closing Date: Check the website

Funding: Private

Additional Information: Applicants must demonstrate a specific need to use the primary research collections in the CHF Library for their research. Please check at www.chemheritage.org/research/ beckman-center/beckman-center-fellowships/short-term-fellowships. aspx for further details.

\section{Société de Chimie Industrielle (American Section) Fellowship}

Subjects: The history of science.

Purpose: To stimulate public understanding of the chemical industries, using both terms in their widest sense.

Eligibility: Applications are encouraged from writers, journalists, educators and historians of science, technology and business. Level of Study: Postdoctorate, Doctorate, Postgraduate Type: Fellowship

Value: US $\$ 10,000$ paid in biweekly installments

Length of Study: A minimum of 3 months

Frequency: Annual

Study Establishment: Chemical Heritage Foundation

Country of Study: United States of America

No. of awards offered: 1

Application Procedure: Applicants must apply online at the website.

Closing Date: February 15th

Funding: Private

No. of awards given last year: 1

Additional Information: Multimedia, popular book projects and Webbased projects are encouraged. Please check at www.chemheritage. org/research/beckman-center/beckman-center-fellowships/shortterm-fellowships.aspx for further details.

\section{THE CHEMICAL INSTITUTE OF CANADA}

Suite 400, 222 Queen Street, Ottawa, ON, K1P 5V9, Canada Tel: (1) 6132326252,18885422242 Fax: (1) 6132325862

Email: gthirlwall@cheminst.ca

Website: www.cheminst.ca/awards/cic-awards

Contact: Gale Thirlwall, Awards \& Local Sections Manager

The Chemical Institute of Canada (CIC) is the umbrella organization for three Constituent Societies-the Canadian Society for Chemistry (CSC), the Canadian Society for Chemical Engineering (CSChE) and the Canadian Society for Chemical Technology (CSCT). The CIC establishes strategic direction and identifies synergies in matters of common interest to the Constituent Societies, to enhance the image of the chemical sciences and engineering with all sectors of the public and to deliver common services to individual members. 


\section{CIC Award for Chemical Education}

Subjects: Chemistry and chemical engineering.

Purpose: To recognize a person who has made outstanding contributions in Canada to education at the post-secondary level in the field of chemistry or chemical engineering.

Level of Study: Professional development

Type: Award

Value: A framed scroll, $\$ 1,500$ cash

Frequency: Annual

Country of Study: Canada

No. of awards offered: 1

Application Procedure: Applicants must be nominated. The applicant should submit a curriculum vitae with letters of support and the $\mathrm{CIC}$ nomination.

Closing Date: July 2nd

Funding: Private

Contributor: CIC Chemical Education Fund

No. of awards given last year: 1

Additional Information: Please check at www.cheminst.ca/awards/ cic-awards for further details.

\section{CIC Catalysis Award}

Subjects: Chemistry/chemical engineering.

Purpose: To recognize an individual who has made a distinguished contribution to the field of catalysis while resident in Canada.

Level of Study: Research

Type: Award

Value: A rhodium-plated silver medal and travel expenses to present the Award Lecture

Frequency: Every 2 years

Country of Study: Canada

No. of awards offered: 1

Application Procedure: Applicants must be nominated. They should submit a nomination form, curriculum vitae, bio and citation, letters of support.

Closing Date: October 1st (odd years only, i.e. 2015, 2017...)

Funding: Foundation

Contributor: Canadian Catalysis Foundation

Additional Information: Please check at www.cheminst.ca/awards/ cic-awards for further details.

\section{CIC Macromolecular Science and Engineering Lecture \\ Award}

Subjects: Macromolecular science and engineering

Purpose: To recognize an individual who has made a distinguished contribution to macromolecular science or engineering.

Level of Study: Research

Type: Award

Value: A framed scroll, $\$ 2,000$ cash prize

Frequency: Annual

Country of Study: Canada

No. of awards offered: 1

Application Procedure: Applicants must be nominated. The applicant must submit a nomination form, curriculum vitae, bio and citation, and letters of support.

Closing Date: July 2nd

Funding: Private

Contributor: NOVA Chemicals Limited

No. of awards given last year: 1

Additional Information: Please check at www.cheminst.ca/awards/ cic-awards for further details.

\section{CIC Medal}

Subjects: Chemistry, chemical engineering and chemical

technology.

Purpose: To recognize a person who has made an outstanding contribution to the science of chemistry or chemical engineering in Canada.

Level of Study: Research

Type: Award

Value: A medal and travel expenses to the CSC or CSChE

conference to present the plenary lecture

Frequency: Annual

Country of Study: Canada

No. of awards offered: 1
Application Procedure: Applicants must be nominated. The applicant must submit (1) nomination form, (2) curriculum vitae, (3) bio and citation, and (4) letters of support.

Closing Date: July 2nd

Funding: Private

No. of awards given last year: 1

Additional Information: Please check at www.cheminst.ca/awards/ cic-awards for further details.

\section{CIC Montreal Medal}

Subjects: Chemistry, chemical engineering and chemical technology.

Purpose: To honour a person who has shown significant leadership in or outstanding contribution to the profession of chemistry or chemical engineering in Canada.

Eligibility: Open to administrative contributions within the Chemical Institute of Canada and other professional organizations that con-

tribute to the advancement of the professions of chemistry and chemical engineering. Contributions to the sciences of chemistry and chemical engineering are not considered. Administrative contributions to the $\mathrm{CIC}$, contributions by chemical educators and by staff members of chemical industries and single individual exploits which contribute to the advancement of the chemical profession.

Level of Study: contribution within the chemical community

Type: Award

Value: A medal and travel expenses to the CSC or CSChE

conference to present the plenary lecture

Frequency: Annual

Country of Study: Canada

No. of awards offered: 1

Application Procedure: Applicants must be nominated. The applicant must submit an application form, curriculum vitae, bio and citation and letters of support.

Closing Date: July 2nd

Funding: Private

Contributor: Montréal CIC Local Section

No. of awards given last year: 1

Additional Information: Please check at www.cheminst.ca/awards/ cic-awards for further details.

\section{Environmental Division Research and Development Dima Award}

Subjects: Environmental Chemistry or Environmental Chemical Engineering.

Purpose: To award distinguished contributions to the field of Environmental Chemistry or Environmental Chemical Engineering. Eligibility: Open to any scientist or engineer residing in Canada who has made distinguished contributions to research and/or development in the fields of environmental chemistry or environmental chemical engineering.

Type: Award

Value: A framed scroll, $\$ 1,000$ cash, and up to $\$ 1,000$ for travel expenses to the CSC Conference, if required

Frequency: Annual

No. of awards offered: 1

Application Procedure: Applicants must submit electronically nomination package to the Awards manager.

Closing Date: July 2nd

Funding: Private

Contributor: P. Beaumier

Additional Information: Please check at www.cheminst.ca/awards/ cic-awards for further details.

\section{CHHATRAPATI SHIVAJI MAHARAJ VASTU SANGRAHALAYA}

159-161, Mahatma Gandhi Road, Fort, Mumbai, Maharashtra 400023, India

Contact: Chhatrapati Shivaji Maharaj Vastu Sangrahalaya

The Chhatrapati Shivaji Maharaj Vastu Sangrahalaya, abbreviated CSMVS and formerly named the Prince of Wales Museum of Western India, is the main museum in Mumbai, Maharashtra. 


\section{Dr. Devangana Desai Endowment Scholarships}

Purpose: Scholarships are available for pursuing research programme.

Eligibility: Citizens of India are eligible to apply.

Level of Study: Doctorate, Postdoctorate, Postgraduate

Type: Scholarship

Value: Senior scholarship will receive total endowment amount of Rs. 2,50,000 while the Junior scholarship will receive total endowment amount of Rs. 1,50,000

Country of Study: India

Application Procedure: The mode of applying is online. Visit website https://scholarship-positions.com/dr-devangana-desai-endowmentscholarships-in-india/2018/04/20/ for more details.

Closing Date: May 18th

\section{CHIANG CHING KUO FOUNDATION FOR INTERNATIONAL SCHOLARLY EXCHANGE}

\author{
13F, 65 Tun Hwa South Road, Section 2, 106-ROC, \\ Taiwan \\ Tel: (886) 227045333 \\ Fax: (886) 227016762 \\ Email: cckf@ms1.hinet.net \\ Website: www.cckf.org
}

The Chiang Ching Kuo Foundation for International Scholarly Exchange is a non-profit organization headquartered in Taipei, the capital of the Republic of China. The Foundation was established in 1989 in honour of the late President Chiang Ching kuo. The main objective of the Foundation is to promote the study of Chinese culture and society, broadly defined.

\section{CCK Fellowships for PhD Dissertations}

Subjects: Chinese studies in the humanities and social sciences. Purpose: Supporting doctoral candidates who are enroled in an accredit European university to complete their dissertations. Eligibility: Applicants should have completed all other requirements for their PhD degrees. Applicants should be enroled in an accredited European university.

Level of Study: Doctorate

Type: Fellowship

Value: $€ 15,000$

Length of Study: 1 year

Frequency: Annual

No. of awards offered: Varies

Closing Date: January 15th

Funding: Foundation

No. of awards given last year: 11

No. of applicants last year: 44

\section{Chiang Ching Kuo Foundation Doctoral Fellowships}

Subjects: Chinese studies in the field of humanities and social sciences.

Purpose: To financially support Doctoral candidates while writing their dissertations.

Eligibility: Open to applicants who have completed all other requirements for their $\mathrm{PhD}$ degree except the dissertation. Candidates must not be employed or receive grants from other sources. Level of Study: Doctorate

Type: Fellowships

Value: Up to US $\$ 15,000$

Length of Study: 1 year

Frequency: Annual

No. of awards offered: Varies

Application Procedure: Applicants need to submit a 1 page summary of the proposed project, budget, curriculum vitae and detailed description of the proposed project along with the application form. Application forms are available online.

Closing Date: October 15th

Funding: Private, commercial

For further information contact:

Email: cckf@ms1.hinet.net
Chiang Ching Kuo Foundation for International Scholarly Exchange Eminent Scholar Lectureship

Subjects: All subjects.

Purpose: To sponsor eminent foreign scholars to come to Taiwan to take up lectureships or positions as visiting scholars.

Eligibility: Open to eminent scholars invited by universities or academic institutions of Taiwan.

Level of Study: Lectureship

Type: Lectureship/Prize

Value: New Taiwan $\$ 2,000,000$

Length of Study: 1 year

Frequency: Annual

Study Establishment: Universities or academic institutions in Taiwan Country of Study: Taiwan

Application Procedure: Applicants must use the application forms provided by the Foundation. The application must be sent by registered mail to the Secretariat. Electronic version of all application materials must be enclosed on diskette or sent as email attachment to cckf@ms1.hinet.net with heading 'Application Materials from (Name)' in the header of the message. Applications are accepted from

June 1st.

Closing Date: October 15th

Funding: Foundation

Additional Information: Project directors who are currently receiving Foundation aid are ineligible to apply. Project directors may not submit more than one application.

For further information contact:

Email: cckf@ms1.hinet.net

\section{Chiang Ching Kuo Foundation for International Scholarly Exchange Publication Subsidies}

Subjects: Academic works, periodicals, and journals.

Purpose: To assist in the final stages of publishing academic works. Eligibility: Open to scholars in the final stages of publishing academic works. Applications from scholars affiliated with institutions in Taiwan must involve cooperation with one or more scholars from other countries. Applicants for publication subsidies must be affiliated with a university or other academic institution.

Type: Grant

Value: Ranges between New Taiwan $\$ 5,000$ and $\$ 10,000$. Publication Subsidy Grants may only be used to cover editing, indexing, and other relevant publication costs. Translation and research-related expenses may not be included

Application Procedure: Applicants must use the application forms provided directly from the Foundation Secretariat. Three copies of the application and supporting documents must be submitted by registered mail to the Secretariat. In addition, electronic version of all application materials must be enclosed on diskette or sent as email attachment to cckf@ms1.hinet.net with heading 'Application Materials from (Name)' in the header of the message.

Closing Date: September 15th and January 15th

Funding: Trusts

Additional Information: Please check the website for more details.

For further information contact:

The Chiang Ching-kuo Foundation for International Scholarly

Exchange

Email: cckfnao@aol.com

\section{Conference and Seminar Grants}

Subjects: Chinese studies in humanities and social sciences.

Purpose: Supporting conferences and seminars on specific subjects related to Chinese studies.

Eligibility: Academic scholars in American, European and Asian Pacific universities are eligible to apply for Conference and Seminar grantee.

Type: Grant

Value: Up to $\$ 25,000$

Frequency: Biannual

No. of awards offered: Varies in accordance to our budget

Closing Date: September 15th for Conference and Seminars from

January through June of the following year; January 15th for 
Conference and Seminars from July through December of the same year

Funding: Foundation

No. of awards given last year: 18

No. of applicants last year: 44

Additional Information: The number includes grantees of American,

European and Asian-Pacific universities.

\section{Doctoral Fellowships}

Subjects: Chinese studies in humanities and social sciences.

Purpose: Supporting doctoral candidates for completing their dis-

sertation in the last stage of their doctoral programs.

Eligibility: Applicants should have completed all other requirements for their PhD degree. Applicants should be enroled in an accredited university in the US, Canada, Mexico, and Central and Southern

America.

Level of Study: Doctorate

Type: Fellowship

Value: US\$18,000

Length of Study: 1 year

Frequency: Annual

No. of awards offered: Varies

Closing Date: October 15th

Funding: Foundation

No. of awards given last year: 28

No. of applicants last year: 104

For further information contact:

The Chiang Ching-kuo Foundation for International Scholarly

Exchange, 8361 B Greensboro Dr, McLean, VA, 22102, United

States of America

Tel: (1) 7039037460

Fax: (1) 7039037462

Email: cckfnao@aol.com

\section{Junior Scholar Grants}

Purpose: The Foundation provides grants for time off for research and writing to postdoctoral and assistant professors without tenure who are affiliated with an accredited American university and who have taught for no more than 6 years since receiving PhD degree. Eligibility: Junior Scholar Grants is only available for applicants who are affiliated with an American university.

Type: Grant

Value: Up to $\$ 30,000$

Frequency: Annual

No. of awards offered: Varies

Closing Date: October 15th

Funding: Foundation

No. of awards given last year: 20

No. of applicants last year: 80

For further information contact:

The Chiang Ching-kuo Foundation for International Scholarly Exchange, 8361 B Greensboro Dr, McLean, VA, 22102, United

States of America

Tel: (1) 7039037460

Fax: (1) 7039037462

Email: cckfnao@aol.com

\section{Lecture Series Grants}

Subjects: Chinese studies in humanities and social sciences. Purpose: Supporting lectures by distinguished scholars at the sponsoring institutions.

Eligibility: Lecture Series Grants are only available for European universities sponsoring the lectures of distinguished professors.

Type: Grant

Value: Maximum amount is $€ 25,000$

Frequency: Annual

No. of awards offered: Varies

Closing Date: August

Funding: Foundation

No. of awards given last year: 1

No. of applicants last year: 1

\section{Postdoctoral Research Fellowships}

Subjects: Chinese studies in the humanities and social sciences.

Purpose: To support Junior Scholars who do not hold full-time positions to revise their dissertations for publication or start a new research project.

Eligibility: Applicants who have received $\mathrm{PhD}$ degrees within 5 years are eligible to apply for it. Applicants who have not received PhD degrees should submit proof of the completion of their defense. Level of Study: Postgraduate

Type: Fellowship

Value: $€ 21,000$ per grant per year

Length of Study: Up to 2 years

Frequency: Annual

No. of awards offered: Varies

Closing Date: January 15th

Funding: Foundation

No. of awards given last year: 2

No. of applicants last year: 19

\section{Publication Subsidies}

Subjects: Chinese studies in humanities and social sciences.

Purpose: Applications may be submitted for the publication of scholarly works related to Chinese studies in humanities and social sciences.

Eligibility: Academic scholars in American, European and Asian-

Pacific universities are eligible to apply for Publication subsidies.

Value: US $\$ 5,000-10,000$

Frequency: Biannual

No. of awards offered: Varies

Application Procedure: All applications must be submitted to our online application database. Email and paper applications will not be accepted. The online application database is available annually from August 1 to September 15 and December 1 to January 15 of the following year (to start the application process, please click here). The Foundation will initially direct all messages and correspondence about the applications to respective project directors. If a grant is approved, the CCK Foundation, in most cases, will then correspond with the university's grant administrator to arrange payments over the period of the grant. The Foundation does not provide a written critique for unsuccessful applications.

Closing Date: September 15th and January 15th

Funding: Foundation

No. of awards given last year: 8

No. of applicants last year: 20

Additional Information: The number includes grantees from American, European and Asian-Pacific universities.

\section{Research Grants}

Subjects: The Foundation provides support for research on Chinese studies in the humanities and social sciences.

Purpose: To encourage researchers focusing on the social, cultural, economic or political development of Taiwan.

Eligibility: Academic scholars in American, European, and Asian-

Pacific universities are eligible to apply for Research Grants.

Type: Research grant

Value: First month $\$ 120$ a day; thereafter $\$ 60$ a day; and round trip costs from the East coast to East Asia are approx. $\$ 1,500$

Length of Study: Up to 3 years

Frequency: Annual

No. of awards offered: Varies in accordance to the budget Application Procedure: Applicants must submit their material to our online application database from every August 1st to October 15th.

Closing Date: October 15th

Funding: Foundation

No. of awards given last year: 21

No. of applicants last year: 94

Additional Information: The number includes grantees from American, European and Asian-Pacific universities.

\section{Scholar Grants}

Subjects: Chinese studies in humanities and social sciences.

Purpose: To help replace half of the salary of faculty on sabbatical, or for time off for research and writing.

Eligibility: Tenure faculty, including full professors and associate

professor, in the accredited universities in the US, Canada, Mexico, and Central and Southern America are eligible to apply for scholar grants. 
Type: Grant

Value: $\$ 40,000$ or $\$ 35,000$

Frequency: Annual

No. of awards offered: Varies

Closing Date: October 15th

No. of awards given last year: 12

No. of applicants last year: 42

For further information contact:

The Chiang Ching-kuo Foundation for International Scholarly

Exchange, 8361 B Greensboro Dr, McLean, VA, 22102, United

States of America

Tel: (1) 7039037460

Fax: (1) 7039037462

Email: cckfnao@aol.com

\section{Senior Scholar Grants}

Subjects: Chinese studies in humanities and social sciences.

Purpose: Support full professors or senior scholars wishing to take 1 year's sabbatical leave to do research a writing.

Eligibility: Senior Scholar Grants are available for applicants who are affiliated with accredited universities in Europe and Asian-Pacific region.

Type: Grant

Value: Up to $\$ 40,000$ or $\$ 35,000$

Frequency: Annual

No. of awards offered: Varies

Application Procedure: Applications should be accompanied by a letter of recommendation from the chairman of the department, from the dean of the college or the provost of the university.

Closing Date: October 15th

Funding: Foundation

\section{CHILDREN'S LITERATURE ASSOCIATION}

1301 W. 22nd Street, Suite 202, Oak Brook, IL, 60523,

United States of America

Tel: (1) 6305714520

Fax: (1) 7088765598

Email: info@childlitassn.org

Website: www.childlitassn.org

Contact: Administrator

The Children's Literature Association is an international organization whose mission is to encourage high standards of criticism, scholarship, research and teaching in children's literature.

\section{ChLA Beiter Graduate Student Research Grant}

Subjects: Children's literature.

Purpose: To fund proposals of original scholarship with the expectation that the undertaking will lead to a publication or a conference presentation and contribute to the field.

Eligibility: Winners must be, or become, members of the Children's Literature Association. Previous recipients are not eligible to reapply until the third year from the date of the first award.

Level of Study: Graduate

Type: Grant

Value: From US\$500-1,500, which may be used to purchase supplies and materials, e.g. books and videos, and as research support, e.g. photocopying, or to underwrite travel to special collections or libraries Frequency: Annual

Country of Study: Any country

No. of awards offered: $1-10$

Application Procedure: Applicants must submit their application online including email address, academic institution and status, the expected date of their degree, a detailed description of the research proposal, a curriculum vitae and two letters of reference, one of which must be from the applicant's dissertation or thesis advisor. See www.childlitassn.org for full details.

Closing Date: February 1st

Funding: Private

No. of awards given last year: 2

No. of applicants last year: unavailable
Additional Information: Applicants should visit the website for further details. If applicants wish to receive guidelines by mail, a stamped addressed envelope must be provided. Please check at www. childlitassn.org/index.php?page = about\&family =ops\&category = 03-Grants_-amp-_Fellowships\&display $=16$ for further details.

\section{ChLA Faculty Research Grant}

Subjects: Children's literature.

Purpose: To award proposals dealing with criticism or original scholarship with the expectation that the undertaking will lead to publication and make a significant contribution to the field of children's literature in the area of scholarship or criticism.

Eligibility: Applicants must be, or become, members of the Children's Literature Association.

Level of Study: Doctorate, Postdoctorate, Postgraduate, Predoctorate, Research

Type: Grant

Value: Individual awards may range US\$500-1,500 and may be used only for research-related expenses such as travel to special collections or materials and supplies. Funds are not intended for work leading to the completion of a professional degree

Frequency: Annual

Country of Study: Any country

No. of awards offered: $1-10$

Application Procedure: Applicants must submit their application online and a curriculum vitae. Applications must include the applicant's name, address, telephone number and email address, details of the academic institution the applicant is affiliated with and a detailed description of the research proposal, not exceeding three single spaced pages, and indicating the nature and significance of the project, where it will be carried out and the expected date of completion. See www.childlitassn.org for full details.

Closing Date: February 1st

Funding: Private

No. of awards given last year: 7

No. of applicants last year: 12

Additional Information: In honour of the achievement and dedication of Dr Margaret P Esmonde, proposals that deal with critical or original work in the areas of science fantasy or science fiction for children or adolescents will be awarded the Margaret P Esmonde Memorial Grant. Applicants should visit the website for further details. If applicants wish to receive guidelines by mail, a stamped addressed envelope must be provided. Please check at www.childlitassn.org/ index.php?page = about\&family =ops\&category =03-Grants -ampFellowships\&display $=15$ for further details.

\section{THE CHINA SCHOLARSHIP COUNCIL}

Level 13, Building A3, No.9 Chegongzhuang Avenue, Beijing, 100044, China

Tel: (86) 66093900

Fax: (86) 6643198

Email: webmaster@csc.edu.cn

Website: www.csc.edu.cn

The China Scholarship council (CSC) is a non-profit institution, which is affiliated with the ministry of education. The main objective of the CSC is to develop the educational, scientific and technological, and cultural exchanges and economic and trade cooperation between China and other countries.

\section{The Barbara and Fred Kort Chinese Fellowship Program}

Subjects: All subjects.

Purpose: To forge Sino-Israeli relations.

Eligibility: Open to Chinese scholars who wish to do postdoctoral research at Bar-Ilan University. The candidates should obtain formal approval from the academic supervisors of Bar-llan University.

Level of Study: Postdoctorate

Type: Fellowship

Value: US\$15,000 per year

Length of Study: 1 year

Frequency: Annual

Study Establishment: Bar-Ilan University

Country of Study: Israel 
No. of awards offered: 100 award within 4 years

Application Procedure: The candidates should obtain formal approval from the academic supervisors of Bar-llan university. Please check with website for other details.

Closing Date: Please check website

Funding: Government

Contributor: China Scholarship Council and Bar-Ilan University, Israel

\section{CHINESE AMERICAN MEDICAL SOCIETY (CAMS)}

41 Elizabeth Street, Suite 600, New York, NY, 10013, United States of America

Tel: (1) 2123344760

Fax: (1) 6463046373

Email: jlove@camsociety.org

Website: www.camsociety.org

Contact: Dr H H Wang, Executive Director

The Chinese American Medical Society (CAMS) is a non-profit, charitable, educational and scientific society that aims to promote the scientific association of medical professionals of Chinese descent. It also aims to advance medical knowledge and scientific research with emphasis on aspects unique to the Chinese and to promote the health status of Chinese Americans. The Society makes scholarships available to medical dental students and provides summer fellowships for students conducting research in health problems related to the Chinese.

\section{CAMS Scholarship Program}

Subjects: Medical or dental studies.

Purpose: To help defray the cost of study.

Eligibility: Open to Chinese Americans, or Chinese students who are residing in the USA. Applicants must be full-time medical or dental students at approved schools within the USA and must be able to show academic proficiency and financial hardship.

Level of Study: Doctorate

Type: Scholarship

Value: Recipients will receive a one-time scholarship in the amount of $\$ 5,000$

Frequency: Annual

Country of Study: United States of America

No. of awards offered: $3-5$

Application Procedure: The preferred method of submission is a complete pdf file via email to jlove@camsociety.org. Application and supporting materials can also be sent by mail to CAMS Scholarship Committee.

Closing Date: 11:59 pm EST, April 30th

Funding: Private

Contributor: Membership and fund-raising

No. of awards given last year: 7

No. of applicants last year: 13

Additional Information: Please check at www.chineseamericanmedicalsociety.cloverpad.org/scholarship for further details.

For further information contact:

CAMS Scholarship Committee, 41 Elizabeth Street, Suite 403, NY 10013

Tel: (212) 3344760

Contact: Jerry Huo, Chairman

\section{CHINOOK REGIONAL CAREER TRANSITIONS FOR YOUTH}

\author{
Room B310, 1701 - 5 Avenue South, Lethbridge, AB, T1J OW4, \\ Canada \\ Tel: (1) 4033283996 \\ Fax: (1) 4033202365 \\ Email: mvennard@pallisersd.ab.ca \\ Website: http://www.careersteps.ca
}

The Chinook regional career transitions for youth aims to improve the school-to-work transitions for students, promoting lifelong learning and coordinating and implementing career development activities and programming for youth.

\section{Alberta Blue Cross 50th Anniversary Scholarships \\ Subjects: All subjects.}

Purpose: To assist young Albertans pursuing post-secondary studies across the province

Eligibility: Open to applicants who are registered Indian, Inuit, or Melis and are residents of Alberta and have financial need.

Level of Study: Postgraduate

Type: Scholarship

Value: Canadian $\$ 375-1,250$

Frequency: Annual

Country of Study: Canada

No. of awards offered: 63

Application Procedure: A completed application form must be sent For further information, please check website.

Closing Date: September 20th

Additional Information: Please check at www.ab.bluecross.ca/ aboutus/scholarship-program.html for further details.

For further information contact:

Alberta Blue Cross Corporate Offices 10009-108 Street NW,

Edmonton, AB T5J 3C5

Fax: 7804988096

\section{Robin Rousseau Memorial Mountain Achievement \\ Scholarship}

Subjects: Mountain leadership and safety.

Purpose: To bring about awareness of ways to improve safety in the mountains.

Eligibility: Applicants must be Alberta residents and active in the mountain community; and plan to study in any recognized Mountain Leadership and Safety program.

Level of Study: Professional development

Type: Scholarship

Value: Course fee

Frequency: Annual

No. of awards offered: 1

Application Procedure: A completed application form must be sent. Closing Date: January 30th (check with website)

For further information contact:

Alberta Scholarship Programs Box 28000 Stn Main, Edmonton, AB T5J 4R4

Tel: 7804278640

Fax: 7804271288

Email: scholarships@gov.ab.ca

\section{Terry Fox Humanitarian Award}

Subjects: Social services.

Purpose: To encourage voluntary humanitarian work.

Eligibility: Open to Canadian citizens who are not more than 25 years of age.

Level of Study: Professional development

Type: Scholarship

Value: Canadian $\$ 3,500-7,000$

Frequency: Annual

No. of awards offered: 20

Application Procedure: In order to be considered for a Terry Fox Humanitarian Award, students must submit an application form in Microsoft Word format, three referee forms and an official transcript of the past 2 years of schooling-no other forms are required. Incomplete application forms will not be considered.

Closing Date: February 1st

For further information contact:

The Terry Fox Humanitarian Award Program, AQ 5003, 8888

University Drive, Burnaby, BC V5A 156

Website: http://terryfoxawards.ca/english/

Toyota Earth Day Scholarship Program

Subjects: Environmental community service.

Purpose: To encourage community service. 
Eligibility: Open to students who have achieved academic excellence and distinguished themselves in environmental community service and extracurricular and volunteer activities.

Level of Study: Professional development

Type: Scholarship

Value: Canadian $\$ 5,000$

Frequency: Annual

No. of awards offered: 20

Application Procedure: Application form available online.

Closing Date: February 15th

For further information contact:

Toyota Earth Day Scholarship Program, III Peter Street, Suite 503, Toronto, ON M5V 2H1

Email: scholarship@earthday.ca

\section{CHOIRS ONTARIO}

Choirs Ontario A-1422 Bayview Avenue, Toronto, ON, M4G 3A7, Canada

Tel: (1) 4169231144

Fax: (1) 4169290415

Email: info@choirsontario.org

Website: www.choirsontario.org

Contact: Melva Graham

Choirs Ontario is an arts service organization dedicated to the promotion of choral activities and standards of excellence. Established in 1971 as the Ontario Choral Federation, Choirs Ontario provides services to choirs, conductors, choristers, composers, administrators and educators as well as anyone who enjoys listening to the sound of choral music. Choirs Ontario operates with the financial assistance of the Ministry of Culture, the Ontario Arts Council, the Trillium Foundation, the Toronto Arts Council and numerous foundations, corporations and individual donors.

\section{Ruth Watson Henderson Choral Competition}

Subjects: Singing, treble voice choirs.

Purpose: To reward new choral works.

Eligibility: Open to all Canadian citizens and landed immigrants.

Participating composers must reside in Canada. There is no age limit.

Level of Study: Unrestricted

Type: Award

Value: Cash prize of Canadian $\$ 1,000$ and a concert performance with one of Toronto's leading choirs

Length of Study: $4-6$ mins

Frequency: Every 2 years

Country of Study: Canada

Application Procedure: Applicants must submit four legible photocopies of the score (not original manuscripts). More than one entry may be submitted, but each entry must be accompanied by a separate entry form and a fee of Canadian $\$ 20$. The composer's name must not appear on any score. Scores will be returned if a stamped addressed envelope is included. Application forms can be downloaded from the website www.choirsontario.org/ruthwatsonhenderson.html.

Closing Date: September 30th

Funding: Private

Contributor: Choirs Ontario

Additional Information: Please see the composition guidelines in website.

\section{CHOSUN UNIVERSITY}

\author{
375 Seosuk-Dong, Dong-Gu, Gwangju, 501-759, Korea \\ Tel: (82) 622306486
}

Email: admission@chosun.ac.kr

Website: http://eng.chosun.ac.kr

Chosun University aims to nurture talented students who can contribute to national and international welfare through providing opportunities of intensive academic research, teaching, and public service based on national educational ideals and the established ideals at our university.
Graduate Research Scholarship Positions at Mobile

\section{Computing Lab in Republic of Korea}

Subjects: Scholarships are awarded in the area of wireless networking and mobile computing (including related fields).

Purpose: Scholarships are offered for graduate research positions at the Mobile Computing Lab, Chosun University, Gwangju.

Eligibility: For PhD applicants: 75 per cent or higher of cumulative GPA/marks/score (preferably in computer/communications engineering or related areas). For MS or integrated MS-PhD applicants: 75 per cent or higher of cumulative GPA/marks/score; good programming skills in $\mathrm{C} / \mathrm{C}++$; good english language skills (TOEFL PBT 550, CBT 210, IBT 80, IELTS 6 or higher if mother tongue is not English); good ability to cooperate with others in a multicultural environment; good ability for highly self-motivated independent research.

Level of Study: Research

Type: Research scholarship

Value: It will cover tuition and living expenses

No. of awards offered: 3

Application Procedure: Interested applicants should send the followings to Prof. Sangman Moh at smmoh@chosun.ac.kr via email: (i) curriculum vitate (including names, date of birth, nationality, gender, contact details, education, work experience, publications, and TOEFL/IELTS score if English is not the mother tongue of the applicant); (ii) scanned academic transcripts of B.S. (and MS for PhD applicants); (iii) scanned TOEFL/IELTS score report; (iv) one-page study plan (clearly stating the research topics the applicant is interested in). Only electronic applications are accepted. The above items (i) to (iv) should be either merged as one PDF file or zipped into one file. All the files should be in the format of.pdf or.doc. The files must be sent by the stated date and should have 'Application to Graduate Research Scholarships for Spring at MCL (Familyname)' as the email title.

Closing Date: Please check website

Additional Information: Scholarship can be taken at Republic of Korea (South Korea).

\section{CHRONIC DISEASE RESEARCH FOUNDATION (CDRF)}

St Thomas' Hospital, 4th Floor, South Wing Block D, Westminster Bridge Road, London, SE1 7EH, England Tel: (44) 02076339790 Fax: (44) 02079228154 Email: christel.barnetson@cdrf.org.uk Website: www.cdrf.org.uk

Contact: Mrs Christel Barnetson, Chief Administrator

The Chronic Disease Research Foundation (CDRF) was established to look at new ways of exploring the genetics of diseases associated with ageing. Its mission is to target those common diseases such as osteoporosis, arthritis, back pain, migraine, asthma and diabetes, inherited from our parents, and prevent and alleviate them now and for future generations. Its principal focus is on comparative studies of identical and non-identical twins, undertaken at the Twin Research Unit of St Thomas' Hospital.

\section{CDRF Project Grants}

Subjects: Medicine and surgery.

Purpose: To provide funds for researchers studying the genetic basis of common chronic diseases associated with ageing in developed countries.

Eligibility: There are no restrictions specified. For more details, see the organization website.

Level of Study: Postgraduate, Research

Type: Award/Grant

Value: UK£30,000-150,000

Length of Study: 2-3 years

Frequency: Dependent on funds available

Country of Study: United Kingdom

No. of awards offered: Dependent on availability of funds Application Procedure: Applicants must submit a preliminary proposal of no more than one side of A4-size paper including an outline of the proposal, a list of principal aims and objectives and scale of funding. If the CDRF's panel of experts consider the project to be of relevance, applicants must then submit a full grant proposal. 
Closing Date: check with website

Funding: Private

No. of awards given last year: None

\section{CDRF Research Fellowship}

Subjects: Medicine and surgery.

Purpose: To promote postgraduate education and enable the charity to carry out further research projects.

Eligibility: See the organization website.

Level of Study: Research, Postgraduate

Type: Scholarships and fellowships

Value: UK£30,000-150,000

Length of Study: $2-5$ years

Frequency: Dependent on funds available

Country of Study: United Kingdom

No. of awards offered: Dependent on availability of funds

Application Procedure: Applicants must submit a preliminary proposal of no more than one side of an A4-size paper including an outline of the proposal, a list of principal aims and objectives and the scale of funding. If the CDRF's panel of experts consider the project to be of relevance, applicants must then submit a proposal for a full grant.

Closing Date: See the organization website

Funding: Private

No. of awards given last year: 2

\section{CHRONIC GRANULOMATOUS DISORDER (CGD) SOCIETY}

\author{
CGD Society, 199A Victoria Street, London, SW1E 5NE, \\ United Kingdom \\ Tel: (44) 08009878988 \\ Email: hello@cgdsociety.org \\ Website: www.cgdsociety.org \\ Contact: Susan Walsh, Head of Research
}

The CGD Society is a member of the Association of Medical Research Charities and the International Patient Organization for Primary Immunodeficiencies (IPOPI). The Trust, founded in 1991, exists to promote research into the cases, inheritance, management, symptoms and cure of CGD.

\section{CGD Society Grants}

Subjects: Topics pertaining to potential cures and treatment of inflammation and infection in chronic granulomatous disorder, basic understanding of the molecular defect and the impact of chronic granulomatous disorder on quality of life.

Purpose: To support thorough research that aims to increase understanding of the cause, inheritance, management and symptoms of chronic granulomatous disorder, and to disseminate the useful results of such research.

Level of Study: Predoctorate, Research, Doctorate, Postdoctorate, Postgraduate

Type: Grant

Value: Over the period 2015-2018 we will be making available $£ 50,000 /$ year in grant funds.

Length of Study: Usually 1-3 years depending on the programme

Frequency: Dependent on funds available

Country of Study: Worldwide

No. of awards offered: $1-2$ each year

Application Procedure: Grants are advertised annually in Nature.

Applicants must initially submit a 4-page outline. These are reviewed by lay reviewers and members of the scientific and medical panel. A number of these are then invited to complete full applications. These are then subjected to a peer review. The medical panel then makes recommendations and trustees announce grant offers.

Closing Date: Check with society

Funding: Private

Contributor: Voluntary donations

No. of awards given last year: 2

No. of applicants last year: 7

Additional Information: Preliminary applications must be made on a form available from the CGD office in Bath. Please check at www.cgdsociety.org/research/applyforagrant for further details.

\section{THE CINCINNATI WORLD PIANO COMPETITION}

1241 Elm Street, Cincinnati, OH, 45203, United States of America Tel: (1) 5137443501

Fax: (1) 5137443504

Email: wpc@cincinnatiwpc.org

Website: www.cincinnatiwpc.org

Contact: Founder/Artistic Director

Though most widely known for its annual competition, the Cincinnati World Piano Competition does much more year-round to accomplish its mission to promote classical piano music-including outreach programs to educate students, concerts to provide exposure for emerging performers, and partnerships with organizations to strengthen the artist fabric of Greater Cincinnati.

\section{Cincinnati World Piano Competition Awards}

Subjects: Musical performance on the piano.

Purpose: To encourage the careers of aspiring young pianists and expose them to the performances of great musicians.

Eligibility: Open to piano students of any nationality who are between the ages 18 and 32.

Level of Study: Unrestricted

Type: Prize

Value: The Artist Division's first prize is US $\$ 20,000$ plus a fully managed debut recital in New York, the second prize is US $\$ 15,000$ and the third US\$10,000. Each semifinalist not advancing to the finals receives $\$ 1,000$ (between 3 and 5 of these)

Country of Study: Any country

No. of awards offered: $6-8$

Application Procedure: Applicants must apply in compliance with the full competition rules and regulations, which are available on request and on the website.

Closing Date: January 31st

Funding: Foundation, corporation, individuals, private

No. of awards given last year: 6

Additional Information: CWPC application process is online. No paper applications will be accepted.

\section{CITY UNIVERSITY, LONDON}

Northampton Square, London, EC1V OHB, United Kingdom Tel: (44) 02070405060

Fax: (44) 02070405070

Email: enquiries@city.ac.uk

Website: www.city.ac.uk

The City University, London has developed into an innovative, forward-looking centre of excellence, with a well-deserved reputation in professional and business education and research. Today, it is ready and equipped to face the educational and professional challenges of the knowledge economy. It has close contacts with the leading professional institutions and with business and industry, both at home and abroad. Their professional links are reflected in their teaching and research staff.

\section{Davis and Lyons Bursaries in Music}

Subjects: Music and performing arts.

Purpose: To support students to acquire postgraduate degree in music at city.

Eligibility: Open to all students (UK/EU and overseas, full-time and part-time) beginning any postgraduate programme in music at city.

Type: Studentships and bursaries

Value: UK£1,000

Length of Study: 1 year

Frequency: Annual

Country of Study: United Kingdom

No. of awards offered: 2

Application Procedure: Check website, www.city.ac.uk/arts-socialsciences/music.

Closing Date: March 1st

Additional Information: An announcement of the Davis and Lyons Bursaries in music outcome will be made in late July. 


\section{CIVIC CONSULTING}

Civic Consulting Alleweldt \& Kara GbR, Potsdamer Strasse 150 D-10783, Berlin, Germany Tel: (49) 3021962295

Fax: (49) 3021962298

Email: info@civic-consulting.de

Website: www.civic-consulting.de

Civic Consulting is an economic and public policy consultancy supporting European and international institutions as well as national governments through research, policy evaluation, and impact assessment. They have special expertise in the areas of consumer policy, financial services, information society, food chain issues, animal health and welfare, public risk management, and good governance.

\section{Research Fellowship for European Researchers at Civic Consulting in Germany}

Subjects: The fellowship is awarded in food chain policy and economics/consumer policy and markets at Civic Consulting in Germany.

Eligibility: Applicants for the fellowship should have at least 1 to 2 years professional or academic experience after graduation in economics, political sciences, law or other relevant subjects. Previous work experience in a research institution, a consultancy or a European/international body would be an advantage, as well as extensive writing experience in an academic, research or consultancy context. Applicants are expected to have genuine and documented interest in economic and legal research at EU level and previous research experience in the relevant field (as documented, e.g. through scientific articles, previous projects or volunteer work). Further requirements are: experience in design and use of quantitative and qualitative research tools (such as survey questionnaires, guidelines for expert interview), proficiency of Word, Excel and possibly SPSS, excellent knowledge of English at the level of a native speaker, and EU residency/work permit. Knowledge of German, French, Spanish or other EU languages are not required but would be an asset. Level of Study: Research

Type: Fellowship

Value: Winners of the fellowship will receive a compensation of $€ 2,000$ per month. Fellows will contribute to ongoing EU studies. Fellows that have successfully contributed to the team will be preferably considered for permanent positions at Civic Consulting Country of Study: Germany

Application Procedure: The mode of applying is electronically. Applications should indicate the position for which they are applying in the subject line, and should be sent by email only to fellowship@civic-consulting.de.

Closing Date: October 20th

Contributor: Civic Consulting

\section{CLARA HASKIL COMPETITION}

Case Postale 234, 31 rue du Conseil, $\mathrm{CH}-1800$ Vevey, Switzerland Tel: (41) 219226704

Fax: (41) 219226734

Email: info@clara-haskil.ch

Website: www.regart.ch/clara-haskil

Contact: Mr Patrick Peikert, Director

The Clara Haskil Competition exists to recognize and help a young pianist whose approach to piano interpretation is of the same spirit that constantly inspired Clara Haskil, and that she illustrated so perfectly.

\section{Clara Haskil International Piano Competition}

Subjects: Piano and music.

Purpose: To recognize and financially help a young pianist.

Eligibility: Open to pianists of any nationality and either sex who are no more than 27 years of age.

Level of Study: Postgraduate

Type: Prize

Value: Swiss Franc 25,000

Frequency: Every 2 years

Country of Study: Any country
No. of awards offered: 1

Application Procedure: Applicants must pay an entry fee of Swiss Franc 200

Closing Date: Check the website

Funding: Corporation, international office, trusts

Contributor: Fondation Nestlé pour l'Art

No. of awards given last year: 2

No. of applicants last year: Approx. 150

Additional Information: The competition is usually held during the last weeks of August or the beginning of September.

For further information contact:

International Piano Competition, Concours Clara Haskil

Tel: 41219226704

Fax: 41219226734

Email: info@clara-haskil.ch

\section{THE CLAUDE LEON FOUNDATION}

\author{
P.O. Box 30538, Tokai, 7966, South Africa \\ Tel: (27) 217870418 \\ Fax: (27) 866145915 \\ Email: postdocadmin@leonfoundation.co.za \\ Website: www.leonfoundation.co.za
}

The Claude Leon Foundation is a South African Charitable Trust. resulting from a Bequest by Claude Leon (1884-1972), A prominent Johannesburg businessman. CLF funds a postdoctoral fellowship programme, now in it's 18th Year - It's goal is the building of research capacity in the faculties of Science, Engineering and Medical Sciences at South African Universities via awards to both South African and foreign postdoctoral scientists.

\section{Claude Leon Foundation Postdoctoral Fellowship}

Subjects: Natural sciences, mathematics, engineering and medical sciences.

Purpose: To fund postdoctoral research.

Eligibility: Open to South African and foreign nationals. Preference will be given to candidates who have received their doctoral degrees in the last 5 years, and to those who are currently underrepresented in South African tertiary institutions.

Level of Study: Postdoctorate

Value: South African Rand 235,000 PA for a 2-year fellowship plus travel grant up to a maximum of South African Rand 45,000 to present a paper on poster at an international conference during the 2 nd year of fellowship

Length of Study: 2 years on renewal after the first year

Frequency: Annual

Study Establishment: South African universities and some institutions. See: www.leonfoundation.co.za/postdoctoral-links.htm

Country of Study: South Africa

No. of awards offered: Variable

Application Procedure: Applications are not accepted directly from candidates. They must have been offered a postdoctoral position at a tertiary institution. The application should then be sent to the

foundation by the institution not by the candidate.

Closing Date: May 31st

Contributor: The Claude Leon Foundation, South Africa

No. of awards given last year: 58

No. of applicants last year: 400

Additional Information: Applications should be sent to the foundation by the institution at which the candidate has secured a postdoctoral position, not by the candidate.

\section{Postdoctoral Fellowships (Claude Leon)}

Subjects: Science, engineering and medical sciences.

Purpose: To fund postdoctoral research.

Eligibility: Open to South African and foreign nationals. Preference will be given to candidates who have received their doctoral degrees in the last 5 years and are currently underrepresented in South African science, engineering and medical science.

Level of Study: Postdoctorate

Type: Fellowship

Value: Rand 185,000

Length of Study: 2 years 
Frequency: Annual

Study Establishment: South African universities and some institutions, e.g. CSIR, Medical Research Council

Country of Study: South Africa

Application Procedure: Application forms are available from the website or the Postdoctoral Fellowships Administrator.

Closing Date: May 31st

Funding: Foundation

Contributor: The Claude Leon Foundation

No. of awards given last year: 45

No. of applicants last year: 350

Additional Information: Applications are NOT accepted directly from candidates. They must have been offered a postdoctoral fellowship and that institution will forwards to the foundation.

\section{CLEMSON UNIVERSITY}

\author{
Clemson, SC, 29634, United States of America \\ Tel: (1) 8646563311 \\ Fax: (1) 8646565344 \\ Email: finaid@clemson.edu \\ Website: www.clemson.edu \\ Contact: Associate Director
}

Clemson University is a selective, public, land-grant university, which is committed to world-class teaching, research and public service in the context of general education, student development and continuing education.

\section{Clemson Graduate Assistantships \\ Subjects: All subjects. \\ Purpose: To assist graduates to be employed as a graduate} assistant.

Eligibility: A student must possess at least a bachelor's degree and be enroled in a graduate degree program. To be eligible for any graduate appointment, a graduate student must satisfy the appropriate minimum graduate level enrollment requirement of nine credit hours during each semester and three credit hours in each summer session.

\section{Level of Study: MBA}

Type: Graduate assistantship

Value: The assistantships pay stipends starting at US $\$ 6.18$ per hour. The pay depends upon job duties and candidate qualifications. In addition, graduate assistants are granted partial remission of academic fees and enjoy some benefits provided to the University faculty and staff. Graduate assistantship presently pay US $\$ 1,044$ per semester in tuition and fees

Length of Study: 2 years

Frequency: Dependent on funds available, on an annual or 9-month basis

Study Establishment: Clemson University

Country of Study: United States of America

No. of awards offered: Varies

Application Procedure: Applicants must contact the various university departments or offices for information or submit a general application with a curriculum vitae to the MBA office.

Closing Date: January 15th

\section{CLEVELAND INSTITUTE OF MUSIC}

\author{
11201 East Boulevard, Cleveland, OH 44106, \\ United States of America \\ Tel: (1) 2167915000 \\ Fax: (1) 2167953141 \\ Email: info@cim.edu \\ Website: www.cim.edu \\ Contact: Kristie Gripp, Director of Financial Aid
}

The Cleveland Institute of Music's mission is to provide talented students with a professional, world-class education in the art of music. The Institute ranks among the top tier music schools across the nation, granting degrees up to the doctoral level. More than 80 per cent of the Institute's alumni perform in major national and international orchestras and opera companies, while others hold prominent teaching positions.
Cleveland Institute of Music Scholarships and Accompanying Fellowships

Subjects: Music.

Eligibility: Candidates for the accompanying fellowships should have a Bachelor of Music Degree or equivalent and must be proficient in English.

Level of Study: Graduate, Postgraduate

Type: Scholarships and fellowships

Value: US $\$ 1,000-38,000$ for scholarships and $\$ 1,000-3,000$ for

accompanying fellowships. No travel grants are provided

Length of Study: 1 academic year for scholarships or from August to the following May for accompanying fellowships. Scholarships are renewable

Frequency: Annual

Study Establishment: The Cleveland Institute of Music

Country of Study: United States of America

No. of awards offered: Approx. 425 scholarships and 15 accompanying fellowships

Application Procedure: Applicants must apply online.

Closing Date: December 1st

Funding: Private

\section{THE COLLEGE OF OPTOMETRISTS}

\author{
42 Craven Street, London, WC2N 5NG, United Kingdom \\ Tel: (44) 02078396000 \\ Fax: (44) 02078396800 \\ Website: www.college-optometrists.org
}

The College of Optometrists, founded in 1980, is a registered charity incorporated by Royal Charter in 1995. It is the single successor body to the British Optical Association, founded in 1895, and The Scottish Association of Opticians, formed in 1921.

\section{College of Optometrists Postgraduate Scholarships} Subjects: Optometry.

Purpose: To support research work in optometry or a closely related subject.

Eligibility: Students must be Fellows or Members of the College, although this requirement does not apply to the project Supervisor Level of Study: Postgraduate

Type: Scholarships

Value: $£ 19,400$ (within London) or $£ 17,180$ (outside London)

Length of Study: Up to 3 years

Frequency: Annual

Country of Study: United Kingdom

No. of awards offered: 11

Closing Date: March 31st

Additional Information: For a copy of the regulations, the conditions of awards and application forms, contact murtagh@college-optometrists.org or through Tel: 02077664364

For further information contact:

The College of Optometrists 42 Craven Street, London, WC2N 5NG, United Kingdom

Tel: (44) 02077664364

Contact: Martin Cordiner

\section{COLLEGEVILLE INSTITUTE FOR ECUMENICAL AND CULTURAL RESEARCH}

14027 Fruit Farm Road, Box 2000, Collegeville, MN, 56321, United States of America

Tel: (1) 3203633366

Fax: (1) 3203633313

Email: staff@collegevilleinstitute.org

Website: www.collegevilleinstitute.org

Contact: Donald Ottenhoff, Executive Director

The Institute for Ecumenical and Cultural Research seeks to discern the meaning of Christian identity and unity in a religiously and culturally diverse nation and world and to communicate that meaning for the mission of the church and the renewal of human community. 
The Institute is committed to research, study, prayer, reflection and dialogue, in a place shaped by the Benedictine tradition of worship and work.

\section{Bishop Thomas Hoyt Jr Fellowship}

Subjects: Ecumenical and cultural research

Purpose: To provide the Institute's residency fee to a North American person of colour writing a doctoral dissertation, in order to help the churches to increase the number of persons of colour working in ecumenical and cultural research.

Eligibility: Open to a North American, Canadian or Mexican person of colour writing a doctoral dissertation within the general area of the Institute's concern.

Level of Study: Postgraduate

Type: Fellowship

Value: US $\$ 5,000$ per year

Length of Study: 1 academic year

Frequency: Annual

Study Establishment: The Institute

Country of Study: United States of America

No. of awards offered: 1 each year (or 2 if for semesters)

Application Procedure: Applicants must apply in the usual way to the Resident Scholars Programme (see separate listing). If invited by the admissions committee to be a Resident Scholar, the person will then be eligible for consideration for the Hoyt Fellowship.

Closing Date: November 1st and February 1st

Funding: Private

No. of awards given last year: 1

No. of applicants last year: 1

For further information contact:

Tel: 3203633367

Email: dottenhoff@collegevilleinstitute.org

Website: http://collegevilleinstitute.org/residencies/available-

fellowships

Contact: Donald B Ottenhoff, Director

\section{COLLEGIO CARLO ALBERTO FOUNDATION (CCAF)}

Via Real Collegio 30, Moncalieri, Turin, 10024, Italy Tel: (39) 116705000

Fax: (39) 116705082

Email: segreteria@carloalberto.org

Website: www.collegiocarloalberto.it

The Collegio Carlo Alberto Foundation (CCAF) was legally constituted on April 27, 2004, at the joint initiative of the Compagnia di San Paolo Foundation and the University of Turin. The Foundation aims to promote, manage and develop, in conjunction with the University of Turin, research and postgraduate education in the fields of economics, finance and law, as well as in related disciplines.

\section{Visiting Research Fellowships}

Subjects: Social science.

Purpose: Recipients are offered the possibility of carrying out research on a subject of their choosing within the social sciences, in an environment that enables them to interact on a daily basis with faculty, research staff and students.

Eligibility: Open to to PhD-holding junior and senior scholars for a period of 1-12 months. Scholars who have not received a Visiting Research Fellowship in the previous 5 years are especially encouraged to apply.

Level of Study: Doctorate, Postdoctorate

Type: Fellowships

Value: The amount of each fellowship depends on the candidate's curriculum and on the available budget. The Collegio covers the cost of an economy round-trip ticket from the place of residence of the Visiting Fellow, and provides logistical assistance in finding accommodation in Torino for the period of stay

Length of Study: 1-12 months

Frequency: Annual

Country of Study: Italy

No. of awards offered: 1 or more
Application Procedure: Interested candidates must submit their applications online at www.carloalberto.org/jobs/visiting-researchfellows/online-application.

Closing Date: Please check website

Additional Information: Recipients are offered the possibility of carrying out research on a subject of their choosing within the socia sciences, in an environment that enables them to interact on a daily basis with faculty, research staff, and students.

\section{COLT FOUNDATION}

New Lane Havant, Hampshire, PO9 2LY, England

Tel: (44) 2392491400

Fax: (44) 2392491363

Email: jackie.douglas@uk.coltgroup.com

Website: www.coltfoundation.org.uk

The primary interest of the Colt Foundation is the promotion of research into medical and environmental problems created by commerce and industry and is aimed particularly at discovering the cause of illnesses arising from conditions at the place of work. The Foundation also makes grants to students taking higher degrees in related subjects.

\section{Colt Foundation PhD Fellowships in Occupational and Environmental Health}

Subjects: Medical and natural sciences including public health and hygiene, sports medicine, biological and life sciences, physiology, or toxicology. Where they relate to occupational health issues.

Purpose: To encourage the young scientists of the future.

Eligibility: Open to any student proposing to take a PhD in the correct subject area in a U.K. university or college.

Level of Study: Doctorate

Type: Fellowship

Value: The stipend rate for the first year is $£ 14,000$ ( $£ 16,000$ inside London), rising with inflation for the following 2 years. U.K. fees will be paid as incurred, together with a sum to cover research expenses

Length of Study: 3 years

Frequency: Annual

Study Establishment: Any U.K. university

Country of Study: United Kingdom

No. of awards offered: 3

Application Procedure: See the website www.coltfoundation.org.uk index.php/students.html for further details.

Closing Date: Check the website

Funding: Foundation

Contributor: Endowment

No. of awards given last year: 2

No. of applicants last year: 31

Additional Information: Interviews in December, if selected.

\section{Occupational/Environmental Health Colt Foundation \\ Fellowships}

Subjects: Fellowships are provided in the field of occupational/ environmental health.

Eligibility: The Foundation awards Fellowships each year to persons who are qualified in science or medicine who are carrying out research within the area of occupational and environmental health at a UK university. Applications open for UK/EU and overseas students. Level of Study: Doctorate

Type: Fellowship

Value: The stipend rate for the first year is $£ 14,000$ ( $£ 16,000$ inside London), rising with inflation for the following 2 years. Payments will include UK/EU fees and overseas candidates applying would be expected to meet the difference in UK/EU and International rates

Length of Study: 3 years

Frequency: Annual

Country of Study: United Kingdom

Application Procedure: See the website www.coltfoundation.org.uk/ index.php/students.html for further details.

Closing Date: September 1st

Contributor: Colt Foundation

Additional Information: Interviews in December, if selected 


\section{COMMONWEALTH EYE HEALTH CONSORTIUM}

International Centre for Eye Health, London School of Hygiene \&

Tropical Medicine, Keppel Street, London, WC1E 7HT, UK Tel: + 44 (0) 2076368636

Contact: Commonwealth Eye Health Consortium

The Commonwealth Eye Health Consortium is a group of expert organizations working together to deliver a five-year programme of fellowships, research, and technology to strengthen eye health systems across the Commonwealth.

\section{CEHC Masters Scholarships in Public Health for Eye Care}

Subjects: Scholarships are awarded to undertake MSc in Public Health for Eye Care.

Purpose: The Masters in Public Health for Eye Care at the London School of Hygiene \& Tropical Medicine is a well-established course that aims to train leaders in the prevention of blindness and to strengthen research and academic capacity for eye care programmes and training facilities, particularly in low- and middle-income countries. Eligibility: See the website.

Value: Several scholarships are awarded each year. Each scholarship covers the following: All course fees, two return flights, dissertation project fund, living costs, accommodation with food at the International Students House in Central London. Find out more about the International Students House.

Study Establishment: Scholarships are awarded to undertake MSc in Public Health for Eye Care

Country of Study: United Kingdom

No. of awards offered: Several scholarships are made available each year

Application Procedure: Apply to the London School of Hygiene \& Tropical Medicine for a place on the course:- For new applicants: LSHTM online application system is open for the 2018/19 academic year now. Apply here:- For those who have been accepted from 2017/ 18: if you have applied and been accepted to the 2017/18 academic year you must request to "be reconsidered" for the 2018/19 academic year. Please contact the LSHTM Registry to be asked to "be reconsidered for 2018/19" Once you have received an offer from the London School of Hygiene \& Tropical Medicine here: CEHC 2018.19MSc Scholarships Application.

Closing Date: May 11th

Additional Information: For more details please browse the website http://scholarship-positions.com/cehc-masters-scholarships-in-publichealth-eye-care-uk/2015/12/28/.

\section{THE COMMONWEALTH FUND}

1 East 75th Street, New York, NY, 10021, United States of America Tel: (1) 2126063800

Fax: (1) 2126063500

Email: grants@cmwf.org

Website: www.cmwf.org

The Commonwealth Fund of New York is a philanthropic foundation established in 1918. The Fund supports independent research on health and social issues and makes grants to improve healthcare practice and policy.

\section{Australian-American Health Policy Fellowship}

Subjects: Health policy issues in Australia and the USA, and shared lessons of both policies.

Purpose: To enable Fellows to gain an in-depth understanding of the Australian health care system and policy process, recent reforms, and models for best practice, thus enhancing their ability to make innovative contributions to policymaking in the US, to improve the theory and practice of health policy in Australia and the US by stimulating the cross-fertilization of ideas and experience and to encourage ongoing health policy collaboration and exchange between Australia and the US by creating a network of international health policy experts.

Eligibility: Open to accomplished, mid-career health policy researchers and practitioners including academics, physicians, decision makers in managed care and other private organizations, federal and state health officials and journalists.

Level of Study: Research

Type: Fellowship

Value: For a full 10-month stay in Australia, the fellowship awards up to Australian $\$ 87,000$ which includes a living allowance, relocation expenses, research related travel and conferences, etc. There is also a family supplement available (e.g. up to $\$ 26,000$ for a partner and two children). Round trip airfares to Australia are also covered

Length of Study: Up to 10 months

Frequency: Annual

Study Establishment: Suitable establishment in Australia

Country of Study: Australia

No. of awards offered: 2

Application Procedure: Please go to www.commonwealthfund.org/ grants-and-fellowships/fellowships/australian-american-health-policyfellowship/application-form to know complete procedure to apply for this program.

Closing Date: October 2nd

Funding: Government

Additional Information: In Australia: Director; International Strategies Branch Portfolio Strategies Division Department of Health and Ageing MDP 85 GPO Box 9848 Canberra ACT 2601; Tel: 01161262894593 Fax: 0116126289 7087. Australian-American Health Policy Fellowships is the successor of the Packer Policy Fellowship Program, which ran from 2003 to 2009. Email at packerpolicyfellowship@health.gov.au.

For further information contact:

Email: ro@cmwf.org

Website: www.commonwealthfund.org/grants-and-fellowships/ fellowships/australian-american-health-policyfellows

Contact: Robin Osborn, Vice President and Director

\section{The Commonwealth Fund Mongan Fellowship in Minority Health Policy}

Subjects: Health policy, public health and management, with special programme activities on minority health issues.

Purpose: To create physician-leaders who will pursue careers in minority health policy.

Eligibility: Open to physicians who are citizens of the USA and who have completed their residency. Additional experience beyond residency is preferred. Applicants must demonstrate an awareness of, or interest and experience in dealing, with the health needs of minority populations, strong evidence of past leadership experience, as related to community efforts and health policy and the intention to pursue a career in public health practice, policy, or academia.

Level of Study: Graduate, Postgraduate, Professional development, Research

Type: Fellowship

Value: US $\$ 60,000$ stipend, full tuition, health insurance, books, travel, and related program expenses, including financial assistance for a practicum project

Length of Study: 1 year

Frequency: Annual

Study Establishment: Harvard Medical School

Country of Study: United States of America

No. of awards offered: Up to 5

Application Procedure: Applications available online at the website: www.cmwf.org/fellowships.

Closing Date: December 15th

Funding: Foundation

For further information contact:

Minority Faculty Development Program, Harvard Medical School, 164 Longwood Avenue, 2nd Floor, Boston, MA, 02115-5818, United

States of America

Tel: (1) 6174322922

Email: mfdp_cfhuf@hms.harvard.edu

Website: www.mfdp.med.harvard.edu/fellows faculty/cfhuf/index.htm Contact: JOAN Y. REEDE, Director, CFHUF

Harkness Fellowships in Healthcare Policy and Practice Subjects: Healthcare policy and health services research.

Purpose: To encourage the professional development of promising healthcare policy researchers and practitioners who will contribute to 
innovation in healthcare policy and practice in the USA and their home countries.

Eligibility: Open to individuals who have completed a Master's degree or $\mathrm{PhD}$ in health services or health policy research. Applicants must also have shown significant promise as a policy-orientated researcher or practitioner, e.g. physicians or health service managers, journalists and government officials, with a strong interest in policy issues. Candidates should also be at the research Fellow to senior lecturer level, if academically based; be in their late 20 s to early 40 s, and have been nominated by their department chair or the director of their institution.

Level of Study: Postgraduate, Professional development, Research Type: Fellowship

Value: US $\$ 130,000$, which covers roundtripairfare to the US, a living allowance, funds for project-related travel, research, conferences, travel to attend

Length of Study: Up to 1 year. A minimum of 6 months must be spent in the USA

Frequency: Annual

Study Establishment: An academic or other research policy institution

Country of Study: United States of America

No. of awards offered: 3 (Australia and New Zealand), 3 (Germany), 2 (Netherlands), 1 (Switzerland) and 5 (UK)

Application Procedure: Applicants must complete a formal application available online at the website www.cmwf.org/fellowships Applicants must be submitted via email.

Closing Date: September 6th (for Australia and New Zealand) and November 14th (Canada, France, Germany, Netherlands, Norway,

Sweden and UK)

Funding: Private

Contributor: The Commonwealth Fund

\section{For further information contact:}

Associate Professor \& Director (Australia), Center for Health Economics Research \& Evaluation, University of Sydney, Mallett Street Campus, 88 Mallett Street, Level 6, Building F, Camperdown, NSW, 2050, Australia

Tel: (61) 293510900

Fax: (61) 293510930

Email: sylviab@pub.health.usyd.edu.au

Contact: Dr Jane Hall

Policy Representative, Executive Director (New Zealand), New Zealand-United States Educational Foundation, PO Box 3465, Wellington, New Zealand

Tel: (64) 4722065

Fax: (64) 4995364

Email: jennifer@fulbright.org.nz

Contact: Ms Jennifer M Gill

\section{CONCORDIA UNIVERSITY}

1455 De Maisonneuve Blvd. W., Montréal, QC, H3G 1M8, Canada Tel: (1) 5148482424

Fax: (1) 5148482812

Website: www.concordia.ca

Contact: Ms Patricia Verret, Graduate Awards Manager

Concordia University is the result of the 1974 merger between Sir George Williams University and Loyola College. The University incorporates superior teaching methods with an interdisciplinary approach to learning and is dedicated to offering the best possible scholarship to the student body and to promoting research beneficial to society.

\section{Bank of Montréal Pauline Varnier Fellowship}

Subjects: Business and commerce.

Purpose: To support graduate students to acquire higher degree in the fields of business and commerce.

Eligibility: Open to women with 2 years of cumulative business experience who are entering full-time studies in the MBA program at the John Molson School of Business. Candidates must be Canadian citizens or permanent residents.

Level of Study: MBA

Type: Fellowship
Value: Canadian $\$ 10,000$ per year

Length of Study: 2 years

Frequency: Annual

Study Establishment: Concordia University

Country of Study: Canada

No. of awards offered: 1

Application Procedure: Applicants must submit a completed application form, three letters of recommendation and official transcripts of all university studies by the closing date.

Closing Date: February 1st

Funding: Private

No. of awards given last year: 1

Additional Information: Academic merit is the prime consideration in the granting of the awards.

For further information contact:

M.B.A. Program, Faculty of Commerce and Administration, Concordia University, 1455 de Maisonneuve Blvd. W., Montreal, QC, H3G 1M8 Tel: 8482424 ext 2717

Email: gradprograms@jmsb.concordia.ca

Contact: Graduate Program Director

\section{Concordia University Graduate Fellowships}

Subjects: All subjects.

Purpose: To support research and encourage academic excellence. Eligibility: Open to graduates of any nationality. Candidates must be planning to pursue a full-time Master's or doctoral study at the University and maintain a minimum CGPA of 3.7 or greater.

Level of Study: Postgraduate

Type: Fellowship

Value: Canadian $\$ 10,000$ at the Master's level non-renewable and Canadian $\$ 10,800$ per year at the doctoral level

Length of Study: Masters: 1 year (3 terms); non-renewable; PhD:

3 years ( 9 terms); renewable

Frequency: Annual

Study Establishment: Concordia University

Country of Study: Canada

No. of awards offered: Approx. 38

Application Procedure: Applicants must submit a completed application form, three letters of recommendation and official transcripts of all university studies by the closing date.

Closing Date: Consult the Faculty/Program to which you are seeking admission concerning their deadline date

Funding: Government, private

No. of awards given last year: 25

No. of applicants last year: 1,050

Additional Information: Academic merit is the prime consideration in the granting of the award. All new admissions will be considered for these awards.

\section{David J Azrieli Graduate Fellowship}

Subjects: All subjects.

Purpose: To support graduate students to undertake higher degree. Eligibility: Open to full-time graduate students entering or currently registered in a Master's or Doctoral program, without citizenship restriction. Candidates must maintain a minimum CGPA of 3.7 or greater.

Level of Study: Postgraduate

Type: Fellowship

Value: Canadian $\$ 15,000$ per year

Length of Study: 1 year, non-renewable

Frequency: Annual

Study Establishment: Concordia University

Country of Study: Canada

No. of awards offered: 1

Application Procedure: Applicants must submit a completed application form, three letters of recommendation and official transcripts of all university studies by the closing date.

Closing Date: February 1st

Funding: Private

No. of awards given last year: 1

No. of applicants last year: 1,050

Additional Information: Academic merit is the prime consideration in the granting of the award. Tenure of the award starts in September. 


\section{J W McConnell Memorial Fellowships}

Subjects: All subjects.

Purpose: To support research and encourage academic excellence. Eligibility: Open to Canadian citizens and permanent residents of Canada who are planning to pursue full-time Master's or doctoral study at the University. Fellowships are awarded on academic merit. Level of Study: Postgraduate

Type: Fellowship

Value: Canadian $\$ 10,000$ at the Master's level and Canadian $\$ 10,800$ per year at the doctoral level

Length of Study: A maximum of 3 terms at the Master's level, nonrenewable and 9 terms at the doctoral level, renewable, calculated from the date of entry into the programme

Frequency: Annual

Study Establishment: Concordia University

Country of Study: Canada

No. of awards offered: Approx. 9

Application Procedure: Applicants must submit a completed application form, three letters of recommendation and official transcripts of all university studies by the closing date.

Closing Date: Consult the Faculty/Program to which you are seeking admission concerning their deadline date

Funding: Private

No. of awards given last year: 15

No. of applicants last year: 800

Additional Information: Academic merit is the prime consideration in granting the awards. All new admissions will be considered for awards.

\section{John W O'Brien Graduate Fellowship}

Subjects: All subjects.

Eligibility: Open to full-time graduate students of any nationality.

Candidates must be planning to pursue a full-time Master's or doctoral study at the University.

Type: Fellowship

Value: Canadian $\$ 4,000$ per term non-renewable

Length of Study: A maximum of 3 terms

Frequency: Annual

Study Establishment: Concordia University

Country of Study: Canada

No. of awards offered: 1

Application Procedure: Applicants must submit a completed application form, three letters of recommendation and official transcripts of all university studies by the closing date.

Closing Date: February 1st

Funding: Private

No. of awards given last year: 1

No. of applicants last year: 1,050

Additional Information: Academic merit is the prime consideration in the granting of awards.

\section{Stanley G French Graduate Fellowship}

Subjects: All subjects.

Purpose: To support research and encourage excellence.

Eligibility: Open to graduates of any nationality. Candidates must be planning to pursue full-time Master's or doctoral study at the University.

Level of Study: Postgraduate

Type: Fellowship

Value: $\$ 3,033$ per term at the Master's level and $\$ 3,533$ at the Doctoral level

Length of Study: A maximum of 3 terms, non-renewable

Frequency: Annual

Study Establishment: Concordia University

Country of Study: Canada

No. of awards offered: 1

Application Procedure: Applicants must submit a completed application form, three letters of recommendation and official transcripts of all university studies by the closing date.

Closing Date: February 1st

Funding: Private

No. of awards given last year: 1

No. of applicants last year: 1,050

Additional Information: Academic merit is the prime consideration in the granting of awards.

\section{CONSERVATION LEADERSHIP PROGRAMME}

Conservation Leadership Programme, Birdlife International, Wellbrook Court, Girton Road, Cambridge, Cambridgeshire, CB3 ONA, England Tel: (44) 1223277318

Fax: (44) 1223277200

Email: clp@birdlife.org

Website: www.conservationleadershipprogramme.org Contact: The Programme Manager

Since 1985, the Conservation Leadership Programme has supported and encouraged international conservation projects that address global conservation priorities at a local level. This is achieved through a comprehensive system of advice, training and awards. The programme is managed through a partnership between $\mathrm{BP}, \mathrm{FFI}, \mathrm{Cl}$, WCS and Birdlife International.

\section{Future Conservationist Awards}

Subjects: Biodiversity conservation.

Purpose: To develop leadership capacity amongst emerging conservationists to address the most pressing conservation issues of our time.

Eligibility: The project must address a globally recognized conservation priority, involve people, have host government approval, be run by teams of at least three people, be student-led, have over 50 per cent students registered, last for less than 1 year and take place in Africa, Asia Pacific, Middle East, Eastern Europe, Latin America or the Caribbean.

Level of Study: Doctorate, Graduate, Postgraduate

Type: Award

Value: Up to $\$ 12,500$

Length of Study: Projects should be less than 1 year in length

Frequency: Annual

Country of Study: This is a global programme

No. of awards offered: Up to 30

Application Procedure: Application forms are available from the website. Applications should be made electronically.

Closing Date: Please check website

Funding: Private

Contributor: BP, BirdLife International, Conservation International,

WildLife Conservation Society, and Fauna and Flora International

No. of awards given last year: 29

No. of applicants last year: 360

Additional Information: Please be sure to check at www.conservationleadershipprogramme.org/FutureConservationistAward.asp often for updated information.

\section{CONSERVATION TRUST}

National Geographic Society, 1145 17th Street NW, Washington, DC, 20036-4688, United States of America Email: conservationtrust@ngs.org

Website: www.nationalgeographic.com/conservation

The objective of the Conservation Trust is to support conservation activities around the world as they fit within the mission of the National Geographic Society. The trust will fund projects that contribute significantly to the preservation and sustainable use of the Earth's biological, cultural, and historical resources.

\section{National Geographic Conservation Trust Grant} Subjects: Conservation.

Purpose: To support cutting programmes that contribute to the preservation and sustainable use of the Earth's resources.

Eligibility: Applicants must provide a record of prior research or conservation action. Researchers planning work in foreign countries should include at least one local collaboration as part of their research teams. Grants recipients are excepted to provide the National

Geographic Society with rights of first refusal for popular publication of their findings.

Level of Study: Research

Type: Research grant

Value: US $\$ 15,000-20,000$

Frequency: Annual

No. of awards offered: Varies 
Application Procedure: Apply online at www.nationalgeographic. com/explorers/grants-programs/conservation-trust-application.

Closing Date: Please check website

Funding: Trusts

Contributor: National Geographic Society

For further information contact:

Conservation Trust, National Geographic Society, 1145 17th Street NW, Washington, DC, 20090-8249

Email: conservationtrust@ngs.org

\section{CONSORTIUM FOR ADVANCED RESEARCH TRAINING IN AFRICA (CARTA)}

Consortium for Advanced Research Training in Africa (CARTA), Nairobi, KE, Kenya

Tel: (254) 204001000

Email: carta@aphrc.org

Website: http://www.cartafrica.org/

CARTA's mission is to promote the health and development of African populations through high-quality research on policy-relevant priority issues. The initiative will foster the emergence of vibrant and viable multidisciplinary research hubs of locally-trained internationally recognized scholars.

\section{CARTA PhD Fellowships}

Subjects: The Consortium for Advanced Research Training in Africa (CARTA) is an initiative of nine African universities, four African research institutes, and select northern partners. The multi-disciplinary CARTA program is open to staff of participating institutions who are interested in conducting their $\mathrm{PhD}$ research on topics relevant to the broad fields of public and population health.

Purpose: CARTA offers an innovative model for doctoral training in sub-Saharan Africa to strengthen the capacity of participating institutions to conduct and lead internationally-competitive research. Eligibility: A Masters degree in a relevant field, Prior admission into a $\mathrm{PhD}$ program is not required for application but awards are contingent on such admission being obtained at one of the participating African universities, Male applicants must be under the age of 40 years and female applicants under the age 45 years.

Level of Study: Postgraduate

Type: Fellowship

Value: Fellowships cover tuition fees, medical insurance and other university fees in special circumstances only.

Length of Study: The fellowship runs for a maximum of 4 years Frequency: The fellowship runs for a maximum of four years Country of Study: Africa

No. of awards offered: 25 phD Fellowships

Closing Date: Check the website

Funding: International Office

Additional Information: Please check website for more details.

\section{CONSULATE GENERAL OF SWEDEN}

\author{
445 Park Avenue, 21st floor, New York, NY, 10022, \\ United States of America \\ Tel: (1) 2128883000 \\ Fax: (1) 2128883125 \\ Email: newyork@consulateofsweden.org \\ Website: www.swedennewyork.com
}

The Consulate General of Sweden in New York represents Sweden in the US, specifically in the New York area. Its broad mission is to provide assistance to Swedes and to promote Swedish interests in the US.

\section{Bicentennial Swedish-American Exchange Fund Travel \\ Grants}

Subjects: Area/ethnic studies, foreign language, social sciences, humanities, business/consumer services and education.

Purpose: To provide financial support for faculty, researchers and professionals to study in Sweden.
Eligibility: Open to citizens or permanent residents of the US. Level of Study: Research, Postgraduate, Professional development Type: Grant

Value: Up to 30,000 SEK

Length of Study: 2-4 weeks

Frequency: Annual

Country of Study: Sweden

No. of awards offered: $2-4$

Application Procedure: Applicants must submit 2 letters of recommendation and a detailed project plan. Application forms are available online.

Closing Date: November 15th

Contributor: Swedish Institute, Stockholm, Sweden

Additional Information: Please check at https://studyinsweden.se/ scholarship/bicentennial-swedish-american-exchange-fund for more information.

\section{COOLEY'S ANEMIA FOUNDATION}

330 Seventh Avenue, \#200, New York, NY, 10001, United States of America

Tel: (1) (800) 5227222

Fax: (1) (212) 2795999

Email: s.buczynski@cooleysanemia.org

Website: www.cooleysanemia.org

The Cooley's Anemia Foundation is dedicated to serving people afflicted with various forms of thalassemia, most notably the major form of this genetic blood disease, Cooley's anemia/thalassemia major.

\section{Cooley's Anemia Foundation Research Fellowship}

Subjects: Clinical or basic research related to thalassemia. Applications on topics such as cardiac and endocrine complications of iron overload, hepatitis $\mathrm{C}$, osteoporosis, bone marrow transplantation, iron chelation and gene therapy are encouraged.

Purpose: To promote an increased understanding of Cooley's anemia, develop improved treatment and achieve a final cure for this life-threatening genetic blood disorder.

Eligibility: Fellows must have adequate preceptorship and guidance by an experienced investigator. The application is expected to be the original work of the candidate, but should reflect the close advice of the interested and involved sponsor. Applicants who are Fellows must have an MD, PhD or equivalent degree, and must not hold a faculty position. Applicants who are junior faculty must have an MD, PhD or equivalent degree, and must have completed less than 5 years at the assistant professor level at the time the applications are due.

Preference will be given to applicants who have not yet achieved R-01 funding from the $\mathrm{NIH}$.

Level of Study: Postgraduate

Type: Fellowship

Value: US $\$ 32,500$ per year

Length of Study: 1 year, renewable for a 2nd year

Frequency: Annual

Study Establishment: Any suitable establishment

Country of Study: Any country

No. of awards offered: 10-15

Application Procedure: Qualified applicants should download an application form from the website.

Closing Date: Please check website

Funding: Private

Contributor: Cooley's Anemia Foundation

No. of awards given last year: 11

Additional Information: The foundation seeks to make an extraordinary commitment towards recruiting doctors to pursue a career investigating thalassemia, especially due to the relatively small patient base in the USA.

\section{COPENHAGEN BUSINESS SCHOOL}

Solbjerg Plads 3, 2000 Frederiksberg, Denmark Tel: (45) 38153815

Email: cbs@cbs.dk

Website: www.cbs.dk 


\section{CBS PhD Scholarship on IT Management}

Subjects: Information technology management.

Eligibility: To be considered, the candidate should have a basic training at the Masters level (similar to the $3+2$ Bologna process). An educational background in the social sciences is necessary. The applicant must have successfully completed the Masters degree before commencing PhD at CBS. The applicants must be fluent in English.

Level of Study: Doctorate, Research

Type: Scholarship

Value: The scholarships are fully salaried positions, according to the national Danish collective agreement. The scholarship includes the tuition fees, office space, travel grants, plus a salary, currently starting with per month approx. DKK 23,770 (approx. €3,160) up to DKK 28,964 (approx. $€ 3,860$ ) depending on seniority, plus a pension contribution totalling 17.1 per cent of 85 per cent of the base salary Length of Study: 3 years

Country of Study: Denmark

No. of awards offered: 1

Application Procedure: Application must be sent via the electronic recruitment system. The application must include a 5-page project description. This research proposal should contain a presentation of an original research question, a description of the initial theoretical framework and methodology, a presentation of the suggested empirical material as well as a work plan. In addition to the research proposal, the application must include copies of a Master's degree certificate or other certificates of a corresponding level, brief curriculum vitae, a list of papers and publications, and one copy of a selected written work (e.g. Master's thesis).

Closing Date: February 28th

Contributor: Copenhagen Business School

Additional Information: The scholarship requires the student to spend a minimum of 12 months of their PhD programme in a research institution in China. Countries of study are Denmark and China.

\section{CORE}

3 St Andrew's Place, London, NW1 4LB, England

Tel: (44) 02074860341

Fax: (44) 02074873734

Email: info@corecharity.org.uk

Website: www.corecharity.org.uk

Contact: Alice Kington, Finance and Research Manager

Core, the Digestive Disorders Foundation, supports research into the cause, prevention and treatment of digestive disorders, including digestive cancers, ulcers, irritable bowel syndrome, inflammatory bowel disease, diverticulitis, liver disease and pancreatitis. Core also provides information for the public that explains the symptoms and treatment of these and other common digestive conditions.

\section{Core Fellowships and Grants}

Subjects: Gastroenterology, such as basic or applied clinical research into normal and abnormal aspects of the gastrointestinal tract, liver and pancreas, and the prevention of and treatment for digestive disorders.

Purpose: To provide funding for gastroenterological research. Eligibility: Open to applicants resident within the UK. Fellowship projects must contain an element of basic science training.

Level of Study: Research, Postgraduate, Doctorate, Postdoctorate Type: Fellowship or Grant

Value: UK£50,000 per year salary and $£ 10,000$ per year consumables (Research Fellowships); $£ 50,000$ total (Development Grants) Length of Study: 1-3 years

Frequency: Dependent on funds available

Study Establishment: Recognized and established research centres Country of Study: United Kingdom

\section{No. of awards offered: Varies}

Application Procedure: Applicants must complete an application form for consideration in a research competition. Details are available from the website.

Closing Date: Varies

Funding: Commercial, foundation, individuals, private, trusts

Contributor: Charitable donations

No. of awards given last year: 4
No. of applicants last year: Varies

Additional Information: Conditions are advertised on the core website www.corecharity.org.uk. Research grants are awarded for specific projects in the same field of interest.

\section{CORNELL UNIVERSITY}

Campus Information and Visitor Relations, Day Hall Lobby, Cornell University, Ithaca, NY, 14853, United States of America

$$
\text { Tel: (1) } 6072559274
$$

Email: humctr-mailbox@cornell.edu

Website: www.arts.cornell.edu/sochum

Contact: Megan Dirks, Program Administrator

Cornell University is a learning community that seeks to serve society by educating the leaders of the future and extending the frontiers of knowledge. The university aims to pursue understanding beyond the limitations of existing knowledge, ideology and disciplinary structure, and to affirm the value of the cultivation and enrichment of the human mind to individuals and society.

\section{Andrew W. Mellon Foundation Graduate Fellowships}

\section{Subjects: Humanities.}

Eligibility: Cornell University graduate students in the humanities who are working on topics related to the year's theme are invited to apply. Applicants must have completed the $\mathrm{A}$ exam and all requirements for the degree other than the dissertation before the application deadline on November. Awards will be restricted to students entering their 4th, 5 th, or 6 th year of study at the time the Fellowship begins.

Level of Study: Postdoctorate

Type: Fellowship

Value: The Fellowship includes a Graduate School tuition waiver, a $\$ 26,000$ stipend, and health insurance

Length of Study: 1 academic year

Frequency: Annual

Study Establishment: Cornell University

Country of Study: United States of America

No. of awards offered: 2

Application Procedure: The application materials must be emailed to humctr-mailbox@cornell.edu by the deadline.Please email materials in a single PDF in the order below with the subject line 'GRADUATE FELLOWSHIP APPLICATION_Last Name'. A list of material that is required to submit is available at www.arts.cornell.edu/ sochum/mellon_grad_fellowships.html.

Closing Date: November 1st

Additional Information: Please check complete information at www. arts.cornell.edu/sochum/mellon_grad_fellowships.html.

\section{Mellon Postdoctoral Fellowships}

Subjects: Arts and humanities.

Purpose: To support the early development of scholars who show promise of distinguished research careers.

Eligibility: Applicants for the Mellon Postdoctoral Fellowship must have received the PhD degree. Mellon Fellowships are no longer restricted to citizens of the US and Canada. International applicants are welcome to apply.

Level of Study: Postdoctorate

Type: Fellowship

Value: A stipend of $\$ 45,000$ per year

Length of Study: 3 years

Frequency: Annual

Study Establishment: Cornell University

Country of Study: United States of America

No. of awards offered: 2

Application Procedure: For application information: www.arts. cornell.edu/sochum/fellowships.html.

Closing Date: Please check website

No. of awards given last year: 2

No. of applicants last year: 150

Additional Information: While in residence at Cornell, postdoctoral Fellows have department affiliation, limited teaching duties and the opportunity for scholarly work. Areas of specialization change each year. Mellon Postdoctoral Fellowships are available in three areas of specialization: department of classics, department of comparative literature and department of music. 


\section{THE COSTUME SOCIETY}

150 Aldersgate Street, London, EC1A 4AB, United Kingdom

Email: info@costumesociety.org.uk

Website: www.costumesociety.org.uk Contact: Sylvia Ayton

The Costume Society, a registered charity was formed in 1965 to promote the study and preservation of significant examples of historic and contemporary costumes and with a constitutional aim of providing education in dress studies.

\section{The Conference Student Bursary}

Subjects: Historic and contemporary dress.

Purpose: To offer a postgraduate student full attendance at the Costume Society's annual conference/symposium exclusive of transport.

Eligibility: Open to UK students at the graduate and postgraduate level engaged in research directed towards a dissertation or thesis on the history and theory of dress. The research should reflect the theme of the Costume Society's current symposium or be an object-based project on the history of dress.

Level of Study: Graduate, Postgraduate

Type: Bursary

Value: Full-time attendance at the 3-day symposium inclusive of accommodation, meals and lecturer visits up to a maximum of $£ 400$ Length of Study: The award offers an intensive three days of study Frequency: Annual

Study Establishment: Not specified

Country of Study: United Kingdom

No. of awards offered: 1

Application Procedure: Please download the application form (CostSoc_Student_Application_2014.pdf) from http://costumesociety. org.uk/awards/symposium-bursary.

Closing Date: May 30th

Funding: Trusts

Contributor: Maney Publishing

No. of awards given last year: 1

Additional Information: Please email (awards@costumesociety.org.

uk) us for further information on this award.

\section{For further information contact:}

The Student Bursary, The Costume Society, c/o Moore Stephens, 150 Aldersgate Street, London, EC1A 4AB

Contact: The Awards Co-ordinator

\section{The Costume Society Museum Placement Award}

Purpose: To support students seeking museum work experience with a clothing/fashion/dress/costume collection and to help U.K. museums accomplish projects essential to the care, knowledge and interpretation of these types of collections. The award has been introduced to fund a student volunteer working on a clothing/fashion/dress/costumerelated project in a public museum collection in the UK. The museum project/work experience should involve at least one of the following activities: documentation, numbering objects, preparing mannequins, mounting garments for display or photography, improving storage. Other appropriate object-related museum activities will be considered. The placement must be for a minimum of 2 months, either full or part-time.

Eligibility: The volunteer should be a student (minimum 2nd year) or graduate of an appropriate U.K. university course, such as dress/ fashion history, museum studies, fashion design, theatre costume design, history, social history, and art history.

Level of Study: Graduate, Postgraduate

Type: Award

Value: Up to $£ 1,000$

Length of Study: 2 months, either full or part-time

Frequency: Annual

Country of Study: United Kingdom

No. of awards offered: 1

Application Procedure: The curator/administrator shall submit the application form with the name of the proposed volunteer and his/her curriculum vitae and a proposal of not more than 500 words detailing the work the volunteer will be engaged in, its benefits to the museum and to the volunteer.

Closing Date: Please check website
Contributor: The Costume Society

No. of awards given last year: 1

No. of applicants last year: 7

Additional Information: Please email (awards@costumesociety.org. uk) us for further information on this award.

For further information contact:

Costume Society Museum Placement Award Co-ordinator, Textiles \& Fashion, V\&A Museum, Cromwell Road, London, SW7 2RL

Contact: Jenny Lister

\section{The Patterns of Fashion Award}

Subjects: Historic and contemporary dress.

Purpose: To support a student on a theatre-wardrobe course at the graduate or post-graduate level who produces a reconstruction of a garment from a pattern in Janet Arnold's books The Patterns of Fashion to a standard which reflects that presented in the books. Eligibility: Open to students studying on costume and fashion-related education courses that involve the design and realization of costume. It is awarded to the student who has, in the opinion of the judges, produced a reconstructed garment from a pattern in one of the Janet Arnold Patterns of Fashion books that reflect the high standards presented in the books.

Level of Study: Graduate, Postgraduate

Type: Grant

Value: UK£500

Length of Study: As applicable to the course

Frequency: Annual

Study Establishment: Open to all courses applicable

Country of Study: United Kingdom

No. of awards offered: 1

Application Procedure: Use link (CostSoc_PofF_Award_Patterns of_fashion_form.pdf) to download the Patterns of Fashion Application Form from http://costumesociety.org.uk/awards/

patterns-of-fashion-award

Closing Date: April 30th

Funding: Trusts

Contributor: The Costume Society

No. of awards given last year: 1

Additional Information: Full details of the Award are published on the Society's website www.costumesociety.org.uk and in Costume, the annual journal of the society.

For further information contact:

The Awards Co-ordinator, The Patterns of Fashion Award, The Costume Society, 150 Aldersgate Street, London, EC1A 4AB, England

\section{The Yarwood Award}

Subjects: The history of historic and contemporary dress.

Purpose: The award is aimed at helping an MA student engaged in high quality research into the history of dress and/or textiles with expenditure relating to the completion of their dissertation.

Eligibility: Applicants have to be enroled in an MA course at a British institution. The history of dress and/or textiles has to be central to their research topic

Level of Study: Postgraduate

Type: Award

Value: Up to UK£500 and a 1-year membership

Frequency: Annual

Study Establishment: An academic institution is selected for a 3-year period

Country of Study: United Kingdom

No. of awards offered: 1

Application Procedure: Please submit a number of docs (list

available at http://costumesociety.org.uk/awards/the-yarwood-award) by the deadline to awards@costumesociety.org.uk putting Yarwood

Award Application into the subject header.

Closing Date: April 30th

Funding: Trusts

Contributor: The Costume Society

No. of awards given last year: 1

Additional Information: If you are unsure whether you are eligible, please emails us at awards@costumesociety.org.uk after reading the following sections. 
For further information contact:

The Costume Society, 150 Aldersgate Street, London, EC1A 4AB Contact: The Yarwood Award Co-ordinator

\section{THE COSTUME SOCIETY OF AMERICA (CSA)}

Costume Society of America, 390 Amwell Road, Suite 402, Hillsborough, NJ, 08844, United States of America Tel: (1) 9083591471

Fax: (1) 9084501118

Email: national.office@costumesocietyamerica.com

Website: www.costumesocietyamerica.com

Contact: Administrative Assistant

The Costume Society of America (CSA) advances the global understanding of all aspects of dress and appearance. The Society seeks as members those who are involved in the study, education, collection, preservation, presentation and interpretation of dress and appearance in past, present and future societies.

\section{Adele Filene Student Presenter Grants}

Subjects: Cultural heritage, museum studies and related areas. Purpose: It provides financial assistance to students who have been selected to present oral research papers or research exhibits at the CSA National Symposium.

Eligibility: Applicants will be evaluated on: be full-time undergraduate or graduate university student; be a current member of the Costume Society of America; have received notice that their proposal for an oral research paper or research exhibit has been accepted for that year's National Symposium; reside outside a 200-mile radius of that symposium site; recipients will be expected to attend the symposium, present their research, and receive their check at the awards ceremony.

Level of Study: Unrestricted

Type: Scholarships

Value: Up to US $\$ 500$

Frequency: Annual

Country of Study: United States of America

No. of awards offered: $1-3$

Application Procedure: Please check at www.costumesocietyamerica.com/GrantsAwards/adelefilene.html for detailed procedure.

Closing Date: March 1st

No. of awards given last year: 4

No. of applicants last year: 3

\section{CSA Stella Blum Student Research Grant}

Subjects: North American costume.

Purpose: To assist the research of a current undergraduate or graduate student who is a member of the Costume Society of America and conducting original research in the field of North American costume.

Eligibility: Applicants must meet the following requirements: be a student matriculating, at the time of the funded research, in a degree program at an accredited institution; propose a research project in the field of North American costume; be a member of the Costume Society of America.

Level of Study: Doctorate, Graduate, Postdoctorate, Postgraduate, Predoctorate

Type: Grant

Value: Up to US $\$ 2,000$ plus a travel component of up to $\$ 500$ to

attend National Symposium to present the completed research

Frequency: Annual

Study Establishment: An accredited institution

Country of Study: United States of America

No. of awards offered: 1

Application Procedure: Candidates must complete an application form, available upon request.

Closing Date: May 1st

No. of awards given last year: 1

No. of applicants last year: 4

Additional Information: The award will be given based on merit rather than need. Judging criteria will include creativity and innovation, specific awareness of and attention to costume matters, impact on the broad field of costume, awareness of the interdisciplinary nature of the field, ability to successfully implement the proposed project in a timely manner and faculty adviser recommendation.

\section{For further information contact:}

5903 60th Avenue, Riverdale, MD, 20737

Contact: Ann Wass, Stella Blum Student Research Grant Committee Chair

\section{CSA Travel Research Grant}

Subjects: Textile and fashion design, museum studies and related areas.

Purpose: To assist an individual (non-student) member of the Costume Society of America to travel and conduct research at a collection at a library, archive, museum or other institution or site in order to further an ongoing research project.

Eligibility: Applicants must meet the following requirements: have been a member of the Costume Society of America for at least the preceding 2 years; provide proof that work on the project is already underway; have confirmed that the collection they propose to visit will grant them a research appointment and that the material to be consulted will be available.

Level of Study: Professional development

Type: Research grant

Value: US $\$ 1,500$

Frequency: Annual

Country of Study: Any country

No. of awards offered: 1

Application Procedure: Please check at www.costumesocietyamerica.com/GrantsAwards/csatravelgrant.html for detailed procedure.

Closing Date: February 26th

No. of awards given last year: 1

No. of applicants last year: 3

\section{THE COUNCIL FOR BRITISH RESEARCH IN THE LEVANT (CBRL)}

The British Academy, 10 Carlton House Terrace, London, SW1Y 5AH, England

Tel: (44) 02079695296

Fax: (44) 02079695401

Email: cbrl@britac.ac.uk

Website: www.cbrl.org.uk

Contact: Penny McParlin, UK Administrative Secretary

In 1998, the British Institute at Amman for Archaeology and History and the British School of Archaeology in Jerusalem amalgamated to create the Council for British Research in the Levant (CBRL). The CBRL promotes the study of the humanities and social sciences as relevant to the countries of the Levant (Cyprus, Israel, Jordan, Lebanon, Palestinian Territories and Syria).

\section{CBRL Pilot Study Award}

Subjects: Humanities and social sciences subjects, e.g. archaeology, economics, geography, historical studies, legal studies, languages and literature, linguistics, music, philosophy, politics, social anthropology, sociology and theology, or religious studies.

Purpose: To enable postdoctoral scholars to undertake initial exploratory work or feasibility study as a preliminary to making applications for major funding to other bodies.

Eligibility: Applicants must be of British nationality or ordinarily resident in the UK, Isle of Man or the Channel Islands. Must be a CBRL member.

Level of Study: Research, Postdoctorate

Type: Research award

Value: The value of individual awards does not normally exceed

UK£7,500 and in most cases will be below that level

Frequency: Annual

Study Establishment: Council for British Research in the Levant No. of awards offered: Varies

Application Procedure: Applicants must complete an application form, available from the U.K. Secretary at the main address or from the website.

Closing Date: December 1st

Funding: Government 
Contributor: The British Academy

No. of awards given last year: 3

No. of applicants last year: 5

\section{CBRL Travel Grant}

Subjects: Humanities and social sciences subjects, e.g. archaeology, economics, geography, historical studies, legal studies, languages and literature, linguistics, music, philosophy, politics, social anthropology, sociology and theology, or religious studies.

Purpose: To cover the travel and subsistence costs of students, academics and researchers undertaking reconnaissance tours or smaller research projects in the countries of the Levant.

Eligibility: Application open to anyone who: (i) is a CBRL member (you may apply for membership when you submit your application for the award); and (ii) is of British nationality; or (iii) is normally resident in the UK; or (iv) is registered as a student in a UK university.

Level of Study: Unrestricted

Type: Travel grant

Value: A maximum of UK£800

Frequency: Annual

Study Establishment: Council for British Research in the Levant

No. of awards offered: Varies

Application Procedure: Applicants must complete an application form, available from the U.K. Secretary at the main address or from the CBRL website.

Closing Date: January 15th

Funding: Government

Contributor: The British Academy

No. of awards given last year: 11

No. of applicants last year: 33

\section{CBRL Visiting Research Fellowships}

Subjects: Humanities and social sciences subjects, e.g. archaeology, economics, geography, historical studies, legal studies, languages and literature, linguistics, music, philosophy, politics, social anthropology, sociology and theology or religious studies.

Purpose: To enable individuals to spend a period of time based at one or more of the CBRL's institutes to conduct research.

Eligibility: Applicants must be of British nationality or ordinarily resident in the UK, Isle of Man or the Channel Islands, or registered on a doctoral degree in a U.K. university. Must be a CBRL member.

Level of Study: Research, Postgraduate, Doctorate, Postdoctorate Type: Fellowship

Value: Fellowship will provide a return airfare between the UK and Levant, a subsistence and free hostel accommodation whilst resident at CBRL's overseas institutes

Frequency: Annual

Study Establishment: Council for British Research in the Levant No. of awards offered: Varies

Application Procedure: Applicants must complete an application form, available from the U.K. Secretary at the main address or from the website.

Closing Date: January 15th

Funding: Government

Contributor: The British Academy

No. of awards given last year: 10

No. of applicants last year: 27

\section{Team-Based Fieldwork Research Award}

Subjects: Humanities and social science, e.g. archaeology, economics, geography, historical studies, languages, linguistics, music, philosophy, politics, social anthropology, sociology and theology, religious studies.

Purpose: To support team-based fieldwork projects focused on either Wadi Faynan area or eastern Badia region of Jordan.

Eligibility: Applicants must be of British nationality or ordinarily resident in the UK, Isle of Man or Channel Islands. Must hold a PHD and should be a CBRL member.

Level of Study: Postdoctorate, Research

Type: Research award

Value: Up to UK£5,000 per year for 2 or 3 years of fieldwork

Study Establishment: Council for British Research in the Levant No. of awards offered: Varies

Application Procedure: Applicants must complete an application form, available from website.
Closing Date: December 1st

Funding: Government

Contributor: British Academy

No. of awards given last year: 2

No. of applicants last year: 3

\section{COUNCIL FOR INTERNATIONAL EXCHANGE OF SCHOLARS (CIES)}

\author{
1400 K Street, NW, Suite 700, Washington, DC, 20005 , \\ United States of America \\ Tel: (1) 2026864000 \\ Fax: (1) 202362 3442/202 6864029 \\ Email: apprequest@cies.iie.org, scholars@iie.org \\ Website: www.cies.org
}

The Council for International Exchange of Scholars (CIES) is a private, non-profit organization that facilitates international exchanges in higher education. Under a co-operative agreement with the U.S. Department of State Bureau of Educational and Cultural Affairs, it assists in the administration of the Fulbright Scholar Program for faculty and professionals. CIES is affiliated with the Institute of International Education.

\section{Fulbright Distinguished Chairs Program}

Subjects: American studies (history, politics and literature), humanities, law, social sciences, computer science and e-commerce, business and management, fine arts, mass communications and journalism.

Purpose: To increase mutual understanding between the people of the USA and other countries and to promote international educational co-operation

Eligibility: Open to citizens of the USA who hold a PhD or equivalent qualification. Candidates should have a prominent record of scholarly achievement. See www.cies.org/Chairs/Eligibility.htm for more details. Level of Study: Postdoctorate

Value: Varies by country. See www.cies.org/program/fulbrightdistinguished-chair-awards for more details

Length of Study: 3-12 months

Frequency: Annual

No. of awards offered: Approx. 30

Application Procedure: Applicants must submit a project statement and an eight-page curriculum vitae, and visit the website for more information.

Closing Date: August 1st

Funding: Government, private

No. of awards given last year: 30

\section{Fulbright Specialist Program}

Subjects: Anthropology, archaeology, business administration, communications and journalism, economics, education, environmental science, information technology, law, library science, political science, public administration, sociology, social work, U.S. studies, urban planning, agriculture, applied linguistics/TEFL, peace and conflict resolution studies, biology education, chemistry education, engineering education, mathematics education, physics education.

Purpose: To offer short-term grants and encourage new types of activities in the Fulbright context. The program also aims to advance mutual understanding, establish long-term co-operation and create opportunities for institutional linkages.

Eligibility: Open to citizens of the USA with a PhD or comparable professional qualifications.

Level of Study: Postdoctorate, Professional development Type: Grant

Value: International economy fare travel and approved related expenses plus a $\$ 200$ per day honorarium. In-country lodging, meals and travel provided by requesting institution

Length of Study: 2-6 weeks

Frequency: Annual

Country of Study: Other

No. of awards offered: Varies

Application Procedure: Applicants must complete the online application, available on the CIES website.

Closing Date: Applications and grants are processed on a rolling basis, consult CIES website for peer review calendar 
Funding: Government

Contributor: U.S. Department of State

Additional Information: Please check at www.cies.org/program/

fulbright-specialist-program for more updated information.

\section{COUNCIL FOR THE ADVANCEMENT OF SCIENCE WRITING, INC. (CASW)}

PO Box 910, Hedgesville, WV 25427, United States of America Tel: (1) 3047546786

Email: diane@casw.org

Website: www.casw.org

Contact: Ms Diane McGurgan, Administrator

The CASW is a group of distinguished journalists and scientists committed to improving the quality of science news reaching the general public.

\section{Taylor/Blakeslee Fellowships for Graduate Study in} Science Writing

Subjects: Journalism.

Purpose: To support graduate study in science writing.

Eligibility: Applicants must have a degree in science or journalism and must convince the CASW selection committee of their ability to pursue a career in science writing for the general public.

Level of Study: Postgraduate

Type: Fellowship

Value: A maximum of US $\$ 5,000$

Length of Study: 1 year

Frequency: Annual

Country of Study: United States of America

No. of awards offered: $2-4$

Application Procedure: Applicants must submit three collated sets of a completed application form, a curriculum vitae, a transcript of undergraduate studies if a student, three faculty recommendations or employer recommendations, three samples of writing on 8.5 by 11 inch sheets only and a short statement of career goals.

Closing Date: July 1st

Funding: Private

No. of awards given last year: 4

No. of applicants last year: $16-20$

Additional Information: Please check at http://casw.org/casw/

graduate-school-fellowships for more updated information.

\section{COUNCIL OF AMERICAN OVERSEAS RESEARCH CENTERS (CAORC)}

\author{
PO Box 37012, MRC 178, Washington, DC, 20013 7012, \\ United States of America \\ Tel: (1) 2026331599 \\ Fax: (1) 2027862430 \\ Email: fellowships@caorc.org \\ Website: www.caorc.org
}

Council of American Overseas Research Centers (CAORC) serve as a base for virtually every American scholar undertaking research in the host countries. The members have centres in many locations across the world.

\section{CAORC Multi-Country Research Fellowship Program for} Advanced Multi-Country Research

Subjects: Humanities, social sciences or allied natural sciences.

Purpose: To advance higher learning and scholarly research and to conduct research of regional or trans-regional significance.

Eligibility: Applicants must have obtained a PhD or be established postdoctoral scholars. The candidate should be a citizen of the US. Preference will be given to Candidates examining comparative and/or cross-regional research.

Level of Study: Research, Doctorate, Postdoctorate

Type: Fellowships

Value: Up to $\$ 10,500$

Frequency: Annual

No. of awards offered: Approx. 9
Application Procedure: The application can be downloaded from the website. To obtain hard copy of the application, please contact CAORC

Closing Date: January

Contributor: U.S. State Department

No. of awards given last year: 9

No. of applicants last year: 120

Additional Information: Scholars must carry out research in at least one of the countries that host overseas research centres. Please check website for further information

\section{COUNCIL OF SCIENTIFIC \& INDUSTRIAL RESEARCH (CSIR)}

Anusandhan Bhawan, 2 Rafi Marg, New Delhi, 110001, India Tel: (91) 01123737889

Fax: (91) 01123710618

Email: headhrdg@csirhrdg.res.in

Website: www.csir.res.in

Council of Scientific \& Industrial Research (CSIR) is a premier national research and development organization in India. It is among the world's largest publicly funded research and development organization. Human Resource Development Group, a division of CSIR, realises this objective through various grants, fellowship, schemes, etc.

\section{CSIR Senior Research Associateship (SRA) Scheme}

Subjects: Agriculture sciences, chemical sciences, earth, atmosphere, ocean and planetary sciences, life sciences, material sciences, mathematical statistics, operation research and computer sciences, physical sciences, engineering sciences, medical sciences, and social sciences and humanities.

Purpose: To provide temporary placement to highly qualified, but unemployed Indian nationals including those returning from abroad, to carry out independent research.

Eligibility: Open to Indian citizens who are not more than 40 years of age and have obtained MTech/ME/MD/MS/MVSc/MPharma/PhD in any branch of science/PhD in social sciences and humanities. The candidate should have followed it by 2 years of research/teaching experience or $\mathrm{PhD}$ in engineering/technology. See www.csirhrdg.res. in/sraform.pdf for more details.

Level of Study: Research, Doctorate, Postdoctorate, Predoctorate Type: Fellowship

Value: INR $21,000-25,810$ per month

Length of Study: 3 years, no extension

Frequency: Annual

Country of Study: India

Application Procedure: Applicants must download the complete application form from the website.

Closing Date: See the organization website for details

For further information contact:

The Head, Human Resource Development Group, CSIR Complex Library Avenue, Pusa, New Delhi, 110012, India

\section{COUNCIL OF SUPPLY CHAIN MANAGEMENT PROFESSIONALS (CSCMP)}

333 East Butterfield Road, Suite 140, Lombard, IL, 60148, United States of America Tel: (1) 6305740985 Fax: (1) 6305740989

Email: membership@cscmp.org Website: www.cscmp.org

Contact: Kathleen Hedland, Director Education and Roundtable Services

The Council of Supply Chain Management Professionals (CSCMP) is a non-profit organization of business personnel who are interested in improving their logistics management skills. CSCMP works in cooperation with private industry and various organizations to further the understanding and development of the logistics concept. This is accomplished through a continuing programme of organized activities, research and meetings designed to develop the theory and 
understanding of the logistics process, promote the art and science of managing logistics systems, and foster professional dialogue and development within the profession.

\section{CSCMP Distinguished Service Award}

Subjects: Supply chain management and logistics.

Purpose: To provide honor to an individual for achievement in supply chain management.

Eligibility: All individuals who have made contributions to the field of supply chain management are eligible for the DSA. This includes practitioners with responsibilities in a functional area of supply chain management, consultants and educators-anyone who has made a significant contribution to the advancement of supply chain management. Please check at http://cscmp.org/career/awards/distinguishedservice-award-process for more detailed information.

Type: Award

Frequency: Annual

Application Procedure: Nominations must be accompanied by a fully completed nomination form and should be emailed to Sue Paulson. Closing Date: April 30th

For further information contact:

Distinguished Service Award Selection Committee

Tel: 16306453469

Email: spaulson@cscmp.org

Contact: Sue Paulson

\section{CSCMP Doctoral Dissertation Award}

Subjects: Any supply chain function.

Purpose: To encourage research leading to advancement of the theory and practice to supply chain management.

Eligibility: Open to all candidates whose doctoral dissertation demonstrates signified originality and contributes to the logistics knowledge base. See http://cscmp.org/downloads/public/education/ awards/dda-guidelines.pdf for details.

Level of Study: Postdoctorate

Type: Award

Value: $\$ 5,000$

Frequency: Annual

Closing Date: May

For further information contact:

Council of Supply Chain Management Professionals, Lombard, IL, 60148

Email: kmcinerney@cscmp.org

Contact: Kathy Mclnerney, Education and Research Assistant

\section{Supply Chain Innovation Award ${ }^{\mathrm{TM}}$}

Subjects: Supply chain.

Purpose: CSCMP's Research Strategies Committee (RSC) and Supply Chain Brain established the Supply Chain Innovation Award in 2005 to highlight and recognize the top players in the supply chain industry when it comes to innovative programs, projects and collaboration.

Eligibility: The submitting company must be a CSCMP member. In addition, each member of your team must be registered for the annual conference by August 1st. All travel, accommodations, and related expenses are the responsibilities of the finalist teams.

Type: Scholarship

Frequency: Annual

Application Procedure: While the finalist teams present their case studies, the panel of judges evaluates the session as it happens live in front of the audience of conference attendees.

Closing Date: Check website

Funding: Private

Contributor: CSCMP's Research Strategies Committee (RSC) and Supply Chain Brain

Additional Information: Please check complete guidelines at http:// cscmp.org/career/awards/supply-chain-innovation-award-competition-guidelines.

\section{For further information contact:}

Tel: 16306453454

Email: cscmpresearch@cscmp.org

Contact: Heather Wood, CSCMP Education Services Coordinator

\section{COUNCIL ON FOREIGN RELATIONS (CFR)}

The Harold Pratt House, 58 East 68th Street, New York, NY, 10065 United States of America

Tel: (1) 2124349400

Fax: (1) 2124349800

Email: fellowships@cfr.org

Website: www.cfr.org

Contact: Janine Hill, Director, Fellowship Affairs and Studies

The Council on Foreign Relations (CFR) is dedicated to increasing America's understanding of the world and contributing ideas to U.S. foreign policy. The Council accomplishes this mainly by promoting constructive debates and discussions, clarifying world issues and publishing Foreign Affairs, the leading journal on global issues.

\section{CFR International Affairs Fellowship in Japan}

Subjects: International relations.

Purpose: To cultivate the US's understanding of Japan and to

strengthen communication between emerging leaders of the two nations. Eligibility: Open to citizens of the US aged $27-45$ who have not had prior substantial experience in Japan. Fellows will be drawn from academia, government institutions, the business community and the media. The programme does not fund pre- or postdoctoral scholarly research, work towards a degree or the completion of projects on which substantial progress has been made prior to the fellowship period. Knowledge of the Japanese language is not a requirement. Level of Study: Professional development

Type: Fellowship

Value: Living expenses in Japan plus international transportation, health and travel insurance and necessary research expenses Length of Study: 3-12 months

Frequency: Annual

Country of Study: Japan

No. of awards offered: $2-5$

Application Procedure: Application is primarily by invitation, on the recommendation of individuals in academic, government and other institutions who have occasion to know candidates particularly well suited for the experience offered by this fellowship. Others who inquire directly and who meet preliminary requirements may also be invited to apply without formal nomination. Those invited to apply will be forwarded application materials.

Closing Date: Between July 1st and October 31st

Funding: Private

Contributor: Hitachi Limited

No. of awards given last year: 3

No. of applicants last year: 6

Additional Information: While the Fellow is not required to produce a book, article or report, it is hoped that some written output will result. Please check at www.cfr.org/thinktank/fellowships/iaf_japan.html for more information.

For further information contact:

Fellowship Affairs, Council on Foreign Relations, 58 East 68th Street, New York, NY, 10065

Tel: 2124349489

Fax: 2124349870

Email: fellowships@cfr.org

\section{CFR International Affairs Fellowships}

Subjects: Important problems in international affairs and their implications for the interests and policies of the USA, foreign states, or international organizations.

Purpose: To bridge the gap between analysis and action in foreign policy by supporting a variety of policy studies and active experiences in policy making.

Eligibility: Open to U.S. citizens aged $27-35$ who are eligible to work in the US. While a PhD is not a requirement, successful candidates should generally hold advanced degrees and possess a solid record of work experience. The programme does not fund pre-or postdoctoral research, work towards a degree, or the completion of projects for which substantial progress has been made prior to the fellowship period.

Level of Study: Research, Professional development

Type: Fellowship 
Value: Stipend of $\$ 95,000$

Length of Study: 1 year, preferably beginning in September

Frequency: Annual

Country of Study: Any country

No. of awards offered: $8-12$

Application Procedure: Interested candidates who meet the program's eligibility requirements can apply online by the deadline.

Closing Date: Between July 1st and October 31st

Funding: Private

No. of awards given last year: 11

No. of applicants last year: 30

Additional Information: While the Fellow is not required to produce a book, article or report, it is hoped that some written output will result. Please check at www.cfr.org/thinktank/fellowships/iaf.html for more information.

For further information contact:

Tel: 2124349489

Email: fellowships@cfr.org

\section{CFR International Affairs Fellowships for Mid-Career \\ Scholars and Professionals}

Purpose: To assist mid-career scholars and professionals in advancing their analytic capabilities and broadening their foreign policy experience. The program aims to strengthen career development by helping outstanding individuals acquire and apply foreign policy skills beyond the scope of their professional and scholarly achievements.

Eligibility: Open to U.S. citizens and permanent residents between the ages of 27 and 35 who are eligible to work in the US. CFR does not sponsor for visas.

Type: Fellowship

Value: Stipend of $\$ 95,000$

Length of Study: 1 year

Country of Study: United States of America

Application Procedure: Interested candidates who meet the program's eligibility requirements can apply online by the deadline. Please check at www.cfr.org/thinktank/fellowships/iaf.html for more details.

Closing Date: Between July 1st and October 31st

Additional Information: Fellows are considered independent contractors rather than employees of CFR, and are not eligible for employment benefits, including health insurance. Candidates who are selected as IAF finalists will be notified between December and January, with finalist interviews scheduled in Washington, DC, and New York City between January and February. Official selections and announcement of IAF awards will be made between February and March.

\section{CRF International Affairs Fellowships in Nuclear Security}

Subjects: Nuclear terrorism, nuclear proliferation, nuclear weapons, nuclear force posture and the security implications of nuclear energy. Eligibility: Only open to faculty members with tenure or on tenuretrack lines at accredited universities and who propose to conduct policy-relevant research on nuclear security issues. Qualified candidates must be U.S. citizens or permanent residents who are eligible to work in the US and be between the ages of 29 and 50. CFR does not sponsor for visas. Former Stanton nuclear security fellows who meet the eligibility requirements can apply.

Type: Fellowship

Value: Stipend of $\$ 125,000$

Frequency: Annual

Country of Study: United States of America

No. of awards offered: 12

Application Procedure: The mode of applying is email. Interested candidates who meet the program's eligibility requirements must submit a cover letter, a curriculum vitae, and a proposal (maximum 1,000 words in length). Each applicant should arrange to have two letters of recommendation sent assessing the policy relevance of the applicant's proposed project as well as the applicant's qualifications for carrying it out.

Closing Date: January 16th

Contributor: Stanton Foundation

Additional Information: Please check at www.cfr.org/thinktank/ fellowships/iaf_nuclear.html for more information.

\section{Edward R Murrow Fellowship for Foreign Correspondents}

Subjects: Issues in international affairs and their implications for the interests and policies of the USA, foreign states, or international organizations.

Purpose: To help the Fellow increase his or her competency in reporting and interpreting events abroad and to give him or her a period of nearly a year of sustained analysis and writing, free from the daily pressures that characterize journalistic life.

Eligibility: Open to any correspondent, editor or producer for radio, television, a newspaper or a magazine widely available in the US who has covered international news. Eligibility is limited to those individuals who are authorized to work in the US and who will continue to be authorized for the duration of the fellowship.

Level of Study: Professional development

Type: Fellowship

Value: A stipend equivalent to the salary relinquished, not to exceed US $\$ 65,000$ for 9 months

Length of Study: 9 months

Frequency: Annual

Study Establishment: The Council headquarters in New York City No. of awards offered: 1

Application Procedure: Application is primarily by nomination. A nomination letter must be submitted to the main address. The nomination letter may be submitted by a Council member, a former or current Murrow Fellow, the candidate's employer, or the candidates themselves. The nomination letter should confirm the candidate's eligibility as well as provide a brief description of their background and why the nominator believes the candidate to be an appropriate prospect for the Fellowship. For those candidates who choose to nominate themselves, their letter should address the same aforementioned issues in addition to providing a copy of their most recent curriculum vitae. Nominees who meet the criteria of the programme will then be forwarded an application form.

Closing Date: February 4th is the deadline for nominations and March 14th is the application deadline

Funding: Private

No. of awards given last year: 1

No. of applicants last year: 10

\section{COUNCIL ON LIBRARY AND INFORMATION RESOURCES (CLIR)}

\author{
1707 L Street, NW Suite 650, Washington DC, 20036 , \\ United States of America \\ Tel: (1) 202939 4750/4751 \\ Fax: (1) 2029394765 \\ Email: abishop@clir.org \\ Website: www.clir.org \\ Contact: Alice Bishop, Senior Program Officer
}

CLIR is an independent, nonprofit organization that forges strategies to enhance research, teaching, and learning in collaboration with libraries, cultural institutions, and communities of higher learning.

\section{Mellon Fellowships for Dissertation Research in Original Sources}

Subjects: Fellowships are provided for dissertation research in the humanities or related social sciences in original sources.

Eligibility: Applicants should be enrolled in a doctoral program in a graduate school in the US (master's thesis research is not eligible) and remain enrolled at the institution throughout the duration of the fellowship; complete all doctoral requirements except the dissertation and be ready to start research for it as early as June 1 st and no later than September 1st, with approval of the dissertation proposal no later than March 31st; plan to do dissertation research primarily in original source material in the holdings of archives, libraries, historical societies, museums, related repositories, or a combination; write the dissertation and receive the Ph.D. degree in a field of the humanities or in a related element of the social sciences (candidates for the EdD, JD, or DD degrees are not eligible). For detailed information, please visit website. Level of Study: Doctorate, Research

Type: Fellowship

Value: Each fellowship provides a stipend of $\$ 2,000$ per month for periods ranging from 9 to 12 months. Each fellow will receive an 
additional $\$ 1,000$ upon participating in a symposium on research in original sources and submitting a report acceptable to CLIR on the research experience. Thus the maximum award will be $\$ 25,000$.

Frequency: Annual

Country of Study: Any country

No. of awards offered: 15

Application Procedure: Application is available at https://www.clir org/fellowships/mellon/applicants.html

Closing Date: December 2nd

Funding: Foundation

Contributor: The Andrew W. Mellon Foundation

No. of awards given last year: 15

Additional Information: Fellowships are offered for 9-12 months.

\section{Postdoctoral Fellowship Program}

Subjects: Humanities, social sciences, sciences.

Purpose: The CLIR Postdoctoral Fellowship Program offers recent Ph.D. graduates the chance to help develop research tools, resources, and services while exploring new career opportunities. CLIR Postdoctoral Fellows work on projects that forge and strengthen connections among library collections, educational technologies, and current research. Host institutions benefit from fellows' field-specific expertise by gaining insights into their collections' potential uses and users, scholarly information behaviors, and current teaching and learning practices within particular disciplines.

Eligibility: Open to candidates who have received a PhD in the field of humanities, social sciences, sciences after January 1, 2012 but before beginning the fellowship between June and September 2017 Level of Study: Postdoctorate

Type: Fellowships

Value: Varies

Length of Study: 1-2 years

Frequency: Annual

Country of Study: United States of America \& Canada

Application Procedure: Application is available at

https://www.clir.org/fellowships/postdoc/applicants

Closing Date: December 30th

Funding: Foundation, private

No. of awards given last year: 22

\section{COUNCIL ON SOCIAL WORK EDUCATION (CSWE)}

1701 Duke Street, Suite 200, Alexandria, VA, 223143457, United States of America

Tel: (1) 7036838080

Fax: (1) 7036838099

Email: info@cswe.org

Website: www.cswe.org

The Council on Social Work Education (CSWE) provides national leadership and a forum for collective action designed to ensure the preparation of competent and committed social work professionals. Founded in 1952, CSWE is a non-profit, tax exempt, national organization representing 2,700 individual members as well as 650 graduate and undergraduate programmes of professional social work education. CSWE's goals include improving the quality of social work education, preparing competent human service professionals and developing new programmes to meet the demands of the changing services delivery systems.

\section{Minority Fellowship Program for Doctoral Students \\ Subjects: Mental health research.}

Purpose: To educate leaders of the nation's next generation of mental health researchers.

Eligibility: Applicants must be American citizens, non-citizen nationals, or have permanent residence status (international students and work visa holders are not eligible to apply); and can include, among others, persons who are American Indian/Alaskan Native; Asian/Pacific Islander (e.g. Chinese, East Indian, South Asian, Filipino, Hawaiian, Japanese, Korean, Samoan); Black; and Hispanic (e.g. Mexican/Chicano, Puerto Rican, Cuban, Central American, South American). Please check at www.cswe.org/CentersInitiatives/ ScholarshipsandFellowships/MFP/76164/31830.aspx for more information.
Level of Study: Graduate

Type: Fellowship

Value: Monthly stipends for a 1-year period to defray living expenses some tuition support may be provided depending on the availability of funds

Length of Study: Monthly stipends for a 1-year period to defray living expenses; some tuition support may be provided depending on the availability of funds. Duration of award is 3 years contingent on funding and whether the fellow maintains satisfactory progress Study Establishment: Schools of Social Work Country of Study: United States of America

No. of awards offered: Varies

Application Procedure: Applicants are strongly encouraged to submit documents before the deadline, as MFP staff are only available to answer questions by email or telephone Monday-Friday 9:00 am to 5:00 pm ET.

Closing Date: February 29th at 5:00 pm (ET)

Funding: Government

Contributor: Center for Mental Health Services, the Center for Substance Abuse Prevention, and the Center for Substance Abuse Treatment in SAMSHA

Additional Information: Applicants should demonstrate potential for and interest in, mental health research, as well as potential for success in doctoral studies and commitment to a career in mental health research.

\section{For further information contact:}

CSWE Minority Research Fellowship Program, 1600 Duke Street, Suite 300, Alexandria, VA, 22314-3421

Minority Fellowship Program-Youth for Master's Students Subjects: Mental health or substance abuse.

Purpose: To reduce health disparities and improve behavioural health-care outcomes for racially and ethnically diverse populations by increasing the number of culturally competent master's-level behavioural health professionals serving children, adolescents, and populations in transition to adulthood (aged 16-25).

Eligibility: Applicants must identify mental health service delivery to at-risk children, adolescents, and transition-age youths as the focus of their specialization and be committed to seeking employment with this target population after graduation. Please check eligibility criteria at www.cswe.org/CentersInitiatives/ScholarshipsandFellowships/MFP/ AboutMFP-Y/76266.aspx.

Level of Study: Graduate

Type: Fellowship

Value: Fellowship recipients receive a 1-year fellowship that includes specialized training on mental health issues of children, adolescents, and transition age youths; a monetary stipend; and other professional development supports

Length of Study: 1 year, award is renewable for up to 3 years upon reapplication if the fellow maintains satisfactory progress

Study Establishment: Schools of Social Work

Country of Study: United States of America

No. of awards offered: Varies

Application Procedure: Applicants must write to the CSWE for an application pack and further information or visit the website.

Closing Date: Varies

Funding: Government

Contributor: The Substance Abuse and Mental Health Services Administration, Center for Mental Health Services

Additional Information: Applicants should demonstrate potential for assuming leadership roles, as well as potential for success in doctoral studies and commitment to a career in providing mental health and/or substance abuse services to ethnic minority clients and communities.

\section{THE COUNTESS OF MUNSTER MUSICAL TRUST}

Wormley Hill, Godalming, Surrey, GU8 5SG, England

Tel: (44) 1428685427

Email: admin@munstertrust.org.uk

Website: www.munstertrust.org.uk

Contact: Mrs Deborah Bacon, Secretary 
The Countess of Munster Musical Trust provides financial assistance towards the cost of studies and maintenance of outstanding post graduate music students who merit further training at home or abroad. Each year, the Trust is able to offer a small number of interest-free loans for instrument purchase to former beneficiaries only.

\section{Countess of Munster Musical Trust Postgraduate Study Awards}

Subjects: Musical studies.

Purpose: To enable students, selected after interview and audition, to pursue a course of specialist or advanced performance studies. Eligibility: Open to all nationalities. Must have successfully completed at least 3 years full-time study at a U.K. higher education institution or have been resident in the UK for at least ten years since birth and be able to prove that, based on the laws and regulations in force on the closing date for applications and his/her personal circumstances, he/she automatically has permission to continue to reside and work in the UK following completion of higher education. Exception to above criteria will be made only for long-term residents of Commonwealth countries, for study in UK only.

Level of Study: Postgraduate, Private Lessons

Type: Grant

Value: By individual assessment to meet tuition fees and main-

tenance according to need, usually up to UK $£ 6,000$

Length of Study: 1 year, with the possibility of renewal

Frequency: Annual

Country of Study: Any country

No. of awards offered: Up to 70

Application Procedure: Online application form, followed by audition and interview if selected.

Closing Date: February 10th

Funding: Private

No. of awards given last year: 85

No. of applicants last year: 330

\section{THE COURTAULD INSTITUTE OF ART}

\author{
Somerset House, Strand, London, WC2R ORN \\ United Kingdom \\ Tel: (44) 02078720220 \\ Email: galleryinfo@courtauld.ac.uk \\ Website: www.courtauld.ac.uk \\ Contact: Dr Gareth Morgan, Registrar Office
}

\section{The Marc de Montalembert Grant}

Subjects: The grant is for a project which can be linked to candidate's professional training, but must be realised outside the usual professional or academic framework. A preference will be shown for projects having to do with Byzantium, the medieval period, or the contemporary Mediterranean world.

Purpose: To discover other Mediterranean cultures and to get a sense of their richness and diversity.

Eligibility: The scholar must be under the age of 30 and from a Mediterranean country.

Level of Study: Research, Unrestricted

Type: Grant

Value: $€ 7,000$

Frequency: Annual

Application Procedure: Please see the Foundation's website for full details of the grant, conditions and how to apply: www.fondationmdm. com/anglais/bourse.html.

Closing Date: December 31st

\section{PhD Studentships in Tudor and Jacobean Artistic Practice}

Subjects: The doctoral thesis would examine the materials and techniques used for portrait painting by Anglo-Netherlandish and Netherlandish émigré artists working in Britain.

Purpose: To support an ongoing research project on Tudor and Jacobean artistic practice called Making Art in Tudor Britain. This project is based on the collections of the National Portrait Gallery in collaboration with the University of Sussex and The Courtauld Institute of Art.
Level of Study: Doctorate, Research

Type: Studentship

Value: $£ 13,590$ per year

Frequency: Annual

Application Procedure: Potential candidates are required to register their interest by providing a curriculum vitae and an outline of their of research interests relevant to the studentship.

Closing Date: October 31st

Additional Information: Please check at www.courtauld.ac.uk/ researchforum/grants/PhDstudentship.shtml or www.npg.org.uk/ research/programmes/making-art-in-tudor-britain.php for more information.

\section{Romney Society Bursary}

Subjects: The art of the eighteenth century with particular reference to the life and times of George Romney (1734-1802) and his contemporaries.

Purpose: To offer a platform to students and academics in their first posts who otherwise may not have the opportunity to be published and to encourage those with an interest in the art of the 18th century with particular reference to the life and times of George Romney (17341802) and his contemporaries.

Eligibility: The area of study should be an aspect of the life or work of George Romney or any contemporary linked to Romney (provided the link is part of the study).

Level of Study: Research, Unrestricted

Type: Bursary

Value: $£ 500$ or $\$ 900$

Frequency: Other

Application Procedure: Applications may be made at any time and should be in the form of a proposal of not more than 150 words.

Closing Date: Applications may be made at any time

\section{Terra Foundation for American Art International Essay \\ Prize \\ Subjects: American art (circa 1500-1980).}

Purpose: The aim of the award is to stimulate and actively support non-U.S. scholars working on American art, foster international exchange of new ideas and create a broad, culturally comparative dialogue on American art.

Eligibility: To be eligible, essays should focus on historical American painting, sculpture, prints, drawings, decorative arts, photography, or visual culture of the same period. Preference will be given to studies that address American art within a cross-cultural context as well as new ways of thinking about American art. Manuscripts previously published in a foreign language are eligible if released within the last 2 years. For scholars from English-language countries, only unpublished manuscripts will be considered.

Level of Study: Research

Type: Award

Value: US $\$ 500$

Frequency: Annual

Application Procedure: These awards are administered by the Smithsonian American Art Museum. For more information about deadlines, eligibility, application procedures, and funding, please visit the Smithsonian American Art Museum website: http://americanart.si. edu/research/awards/terra/

Closing Date: January 15th

Additional Information: Essays should be submitted by email to TerraEssayPrize@si.edu.

\section{Terra Foundation for American Art Postdoctoral Teaching} Fellowship at The Courtauld Institute of Art

Subjects: The award will enable a recent postdoctoral scholar to teach at The Courtauld Institute of Art and to undertake a major research project intended for publication. The fellow will teach one course in the first year and two courses in the second year on selected American art topics.

Purpose: This fellowship is part of an initiative of the Terra Foundation that aims to develop international interest, knowledge and scholarship in the field of historical American art. The scheme offers an early career researcher in the field of historical American art the possibility of gaining experience of research and teaching in a university environment, which will enhance his or her curriculum vitae 
improve his or her prospects of obtaining permanent teaching posts, and further the knowledge of American art.

Eligibility: Applicants are expected to be at an early stage of their career, not currently holding, or having held a permanent university post and having received a doctorate within the 3-year period prior to taking up the award.

Level of Study: Postdoctorate, Research

Type: Fellowship

Value: A salary of $£ 57,702$ (approx. US $\$ 92,300$ ) for this period (payment will be in sterling, subject to tax and National Insurance deductions) (1st year salary: $£ 29,712$ per year; 2 nd year salary: $£ 30,535$ per year pro rata). The total package available including salary, benefits, research, travel and living expenses has a value of up to US $\$ 100,666$

Application Procedure: Applicants are asked to submit (1) a completed application form, with two letters of recommendation, including one from the candidate's supervisor (these can be sent separately); (2) an equal opportunities monitoring form.

Closing Date: January 15th

\section{Terra Foundation for American Art Research Travel Grants}

Subjects: American art or transatlantic artistic relations prior to 1980 Purpose: The Terra Foundation for American Art Research Travel Grants support travel to the US for research projects that concern American art or transatlantic artistic relations prior to 1980.

Eligibility: The foundation only accepts proposals from doctoral students and postdoctoral and senior scholars outside the US. Level of Study: Doctorate, Postdoctorate, Research Type: Grant

Value: Three grants of US $\$ 6,000$ each will be offered to researchers at doctoral level. Three grants of $\$ 9,000$ each will be offered to postdoctoral researchers who have been awarded their doctorate within the past 10 years

Frequency: Annual

Application Procedure: An official Terra Foundation Travel Grant application form. The applicant's curriculum vitae. A description of the applicant's research project demonstrating the need for a sojourn in the USA. Two letters of recommendation (for doctoral candidates, one of these letters should be by the dissertation advisor).

Closing Date: January 15th

\section{Terra Summer Residency in Giverny}

Subjects: These fellowships are awarded to artists who have completed their studies at Master's level (or its equivalent) and doctoral students engaged in research on American art or transatlantic artistic exchange.

Purpose: The Terra Summer Residency in Giverny provides artists and scholars with an opportunity for the independent study of American art within a framework of interdisciplinary exchange and dialogue, and in a site rich in cultural significance.

Eligibility: Candidates worldwide can apply. Applicants must be either: a visual artist with a master's degree or its equivalent at the time of application. Preference is given to applicants who have completed their degree within the past 5 years (download the artist fellowship application form at www.terraamericanart.org/grants/ academic-program-grants/terra-summer-residency). A doctoral candidate researching American art and visual culture prior to 1980 within the US or in the context of international artistic exchange. Candidates should be at an advanced stage of their doctoral research and writing (download the predoctoral scholar fellowship application form at www. terraamericanart.org/grants/academic-program-grants/terra-summerresidency).

Level of Study: Research, Doctorate, Postgraduate

Type: Residency

Value: A $\$ 5,000$ stipend (artists receive an additional $\$ 300$ for the purchase of materials); a travel contribution (up to $\$ 250$ for individuals travelling from Europe; up to $\$ 1,000$ for individuals travelling from outside Europe); and lodging in the Terra Foundation residences and daily lunches

Frequency: Annual

No. of awards offered: 10

Application Procedure: Applicants must submit an application form. Closing Date: January 15 th
Additional Information: For more information about these fellowships, as well as invited senior advisor and guest lecturer positions, please email tsr@terraamericanart.eu.

\section{CRANFIELD UNIVERSITY}

\author{
School of Applied Sciences, Bedfordshire, Cranfield, \\ MK43 OAL, England \\ Tel: (44) 1234754086 \\ Fax: (44) 1234754109 \\ Email: info@cranfield.ac.uk \\ Website: www.cranfield.ac.uk/sas \\ Contact: Vicky Mason, Online Marketing Manager
}

The School of Applied Sciences is recognized globally for its multidisciplinary approach to teaching and research in the key areas of manufacturing, materials, and environmental science and technology. Our focus is on fundamental research and its application, together with teaching, to meet the needs of industry and society.

\section{Cranfield Global Manufacturing Leadership Masters Scholarship \\ Level of Study: Postgraduate \\ Type: Scholarship \\ Value: Tuition fee plus $£ 1,000$ cash \\ No. of awards offered: 30 scholarships are available \\ Closing Date: March 15th}

\section{Cranfield Merit Scholarship in Leadership and Management}

Eligibility: Sub-Saharan African countries are eligible.

Level of Study: Postgraduate

Value: $£ 4,000$ for tuition fees

Country of Study: United Kingdom

Application Procedure: For application details, send an email to studysom@cranfield.ac.uk.

Closing Date: May 25th

\section{Cranfield School of Management: Defence MBA Scholarship for International Students}

Subjects: Business administration.

Eligibility: The Scholarship is open to successful MBA candidates from the Defence sectors who want to pursue a full-time MBA at Cranfield School of Management. Applicants from outside the EU who require a Visa to study in the UK are advised to submit their application sooner than the recommended deadline to ensure enough time is allowed for the visa application process to be completed. Level of Study: Postgraduate

Type: Scholarship

Value: $£ 12,000$

Country of Study: United Kingdom

No. of awards offered: 1

Application Procedure: The mode of applying is online.

Closing Date: May 1st

Contributor: Cranfield School of Management in UK

Additional Information: Applicants who are awarded a scholarship will be notified at the time of the admissions decision.

\section{Cranfield Sub-Saharan Africa Merit Scholarship}

Subjects: Science, engineering, technology, and management. Purpose: To commence full-time study in one of the eligible master courses for the academic year 2018-2019.

Level of Study: Postgraduate

Closing Date: May 25th

\section{Department of Agriculture and Rural Development (DARD) for Northern Ireland}

Subjects: Agricultural and environmental engineering, environmental diagnostics and management, environmental management for business, geographical information management, waste and resource management, land management, water management and environmental engineering.

Purpose: To assist candidates to obtain the necessary qualifications and experience to fit them for advisory, teaching, research and other 
technical work in agricultural and food industries and development of the economy and social infrastructure of rural areas.

Eligibility: Open to full time students only.

Level of Study: Postgraduate

Type: Studentship

Length of Study: 1 year

Frequency: Annual

Study Establishment: Cranfield University, School of Applied

Sciences

Country of Study: United Kingdom

Application Procedure: Application form can be downloaded from

www.dardni.gov.uk.

Closing Date: Please refer to website for further details

Funding: Government

Contributor: DARD

\section{The Diamond Education Grant}

Purpose: Its purpose is to provide grants to assist women to update their skills after employment breaks or to acquire new skills to improve their opportunities for employment and promotion.

Value: Small grants towards tuition fees and other study costs

Application Procedure: Apply online at the Diamond Education

Grant website.

Closing Date: April 15th

Contributor: Soroptimist International

\section{Douglas Bomford Trust}

Subjects: Agricultural and environmental engineering, environmental diagnostics and management, environmental management for business, geographical information management, land management, water management, waste and resource management, water and wastewater engineering, water and wastewater technology and environmental engineering.

Purpose: To advance knowledge, understanding, practice, competence and capability in the application of engineering and physical science to agriculture, horticulture, forestry, amenity, and allied land basal and biological activities for sustainable benefit of the environment and mankind.

Eligibility: Open for students from any country.

Level of Study: Postgraduate

Type: Award

Value: $£ 500-1,000$ depending on application

Length of Study: 1 year

Frequency: Annual

Study Establishment: Cranfield University, School of Applied

Sciences

Country of Study: United Kingdom

Application Procedure: Please check the website www.dbt.org.uk for details.

Closing Date: Please check the website www.dbt.org.uk for details

Funding: Trusts

Contributor: Douglas Bomford Trust

Additional Information: Address for application: website: www.dbt. org.uk and headed 'Student Award Application'

\section{Environmental Issues Award}

Subjects: Land management, geographical information management, water management, water science, environmental management for business, environmental diagnostics and management, environmental engineering and civil engineering.

Purpose: To support educational programmes dealing with environmental issues or support environmental project work.

Eligibility: Applicants must be members of the Institution of

Mechanical Engineers.

Level of Study: Postgraduate

Value: Up to $£ 1,000$

Length of Study: 1 year

Frequency: Annual

Study Establishment: Cranfield University, School of Applied

Sciences

Country of Study: United Kingdom

Application Procedure: Applicants must apply online at www.imech. org/awards.

Funding: Trusts

Contributor: IMechE
Additional Information: Please check at www.imech.org/about-us/ Scholarships and Awards/professional for more information and industry grants/Environmental Issues Award.

\section{Geoplan Scholarship}

Subjects: Geographical information management

Purpose: To provide financial support to selected graduates wishing

to undertake the MSc geographical information management.

Level of Study: Postgraduate

Type: Scholarship

Length of Study: 1 year

Frequency: Annual

Study Establishment: Granfield University, School of Applied

Sciences

Country of Study: United Kingdom

No. of awards offered: 2

Closing Date: August 31st

Funding: Commercial

Contributor: Geoplan

Global Manufacturing Leadership Masters Scholarships

Level of Study: Postgraduate

Type: Scholarship

Value: The scholarship pays for the Cranfield Manufacturing Masters tuition fee and a $£ 1000$ cash maintenance grant

No. of awards offered: Up to 30 Global Manufacturing Leadership

(GML) Masters Scholarships announced for 2018

Closing Date: March 15th

\section{The Lorch Foundation MSc Student Bursary}

Subjects: Available to students wishing to study full-time MSc Water and Wastewater Engineering or MSc Water Management.

Purpose: To assist postgraduate study.

Eligibility: Applicants should be U.K. citizens and possess a minimum 2:1 U.K. Honours degree in Engineering or Physical Sciences or related discipline, and have been offered a place on the 1-year full-time MSc in Water and Wastewater Engineering or Water and Wastewater Technology.

Level of Study: Postgraduate

Type: Bursary

Value: UK£5,000 plus tuition fees

Length of Study: 1 year

Frequency: Annual

Study Establishment: Cranfield University, School of Applied

Sciences

Country of Study: United Kingdom

No. of awards offered: 1

Application Procedure: Applicants must apply directly to the university.

Closing Date: July 31st

Funding: Foundation

Contributor: The Lorch Foundation

No. of awards given last year: 1

Additional Information: The bursary is provided by the Lorch Foundation, a charitable institution founded to support and promote education and research in the field of water purification and related sciences for the benefit of mankind. The successful applicant will undertake thesis research on processes of water purification and industrial effluent recycling as part of the MSc programme.

\section{MSc Research Studentship}

Subjects: The studentship is awarded in developing a parametric cost model for design and manufacturing of agricultural and construction equipment in UK.

Eligibility: Applicants should have a First or Second Class U.K. Honors degree or equivalent in a relevant discipline such as manufacturing and mechanical engineering. Strong manufacturing/ cost engineering knowledge, good interpersonal and communication skills and computer literacy are also required. U.K./EU students are eligible for this research studentship.

Level of Study: Postgraduate

Type: Studentship

Value: Tuition fees and provide a bursary of up to $£ 14,000$ per year for 1 year. Due to funding restrictions this studentship is for U.K./EU 
students only. All non-EU nationals are very unlikely to be eligible for this funding under the Education (Fees and Awards) Regulations 1997 Length of Study: Studentship is for 1 year

Country of Study: United Kingdom

Application Procedure: The mode of applying is online.

Closing Date: October

\section{Panasonic Trust Fellowships}

Subjects: Water and waste water engineering and waste and resource management.

Purpose: To provide financial support to selected graduate engineers wishing to undertake full time Masters courses in subjects related to the environment and sustainability.

Eligibility: Applicants should be U.K. or EU citizen, have a U.K. permanent residence status. Have several years of experience working at a professional level in engineering. Have membership at any grade of a professional engineering institution accredited by the engineering council as a licenced number institution.

Level of Study: Postgraduate

Type: Fellowship

Value: $£ 8,000$

Length of Study: 1 year

Frequency: Annual

Study Establishment: Cranfield University, School of Applied

Sciences

Country of Study: United Kingdom

No. of awards offered: 1

Application Procedure: Application form can be downloaded from www.panasonictrust.net/fellowships/ or contact the Panasonic Trust.

Closing Date: Please check website for details

Funding: Trusts

Contributor: The Royal Academy of Engineering

\section{PhD Research Position}

Purpose: The position is available for research project in measuring technologies for plastic electronic film evaluation and control at Cranfield University.

Eligibility: Suitable applicants will be expected to have a First or Upper Second Class honors degree in a relevant engineering, metrology, mechanical or materials science based discipline. Previous experience in metrology systems, motion systems and materials handling will be of value. UK/EU applicants are eligible for this PhD research position.

Level of Study: Research

Value: It will cover the tuition fees and provide a bursary of up to $£ 19,000$ per year for 1 year. This studentship is for UK/EU students only. All non-EU nationals are very unlikely to be eligible for this funding under the Education (Fees and Awards) Regulations 1997

Length of Study: Fellowship is for 3 years

Country of Study: United Kingdom

Application Procedure: The mode of applying is online.

Closing Date: December 15th

Contributor: Partner Industries Cranfield University

\section{Procter and Gamble: PhD Studentship}

Subjects: The studentship is awarded in complex supply network modelling at Cranfield University in UK.

Eligibility: A good first degree in engineering, computer science, mathematics, or physics is required. Demonstration of programming skills and previous experience in Complex Network Analysis is desirable. UK/EU, Non UK/EU students are eligible for this PhD studentship.

\section{Level of Study: Research}

Type: Studentship

Value: The studentship covers university tuition fees (UK/EU) and provides a tax-free bursary of up to $£ 15,000$ per year, for 3 year duration. Due to funding restrictions this studentship will cover the tuition fees for qualified UK/EU students only. Non UK/EU students are required to pay Cranfield University Tuition Fees

Length of Study: Studentship is available for 3 years

Country of Study: United Kingdom

Application Procedure: The mode of applying is online.

Closing Date: December 30th

Contributor: Procter and Gamble, Cranfield University
Royal Commission Industrial Design Studentships

Subjects: MDes Innovation and Creativity in Industry.

Purpose: To stimulate industrial design capability among the country's most able science and engineering graduates.

Eligibility: Open to applicants with good first degree in engineering or science and an offer of a place on the MDes Innovation and Creativity in Industry at Cranfield.

Level of Study: Postgraduate

Type: Studentship

Value: $£ 10,000$

Length of Study: 1 year

Frequency: Annual

Study Establishment: Cranfield University, School of Applied

Sciences

Country of Study: United Kingdom

No. of awards offered: 6

Application Procedure: Applications can be downloaded from www.royalcommission1851.org.uk/ind des.html.

Closing Date: April 28th

Funding: Trusts

Contributor: Royal Commission

\section{Society for Underwater Technology (SUT)}

Subjects: Offshore and ocean technology

Purpose: To sponsor gifted students in Marine, Science and Engineering to meet industry's critical shortage of suitably qualified entrants.

Eligibility: First degree in an engineering or science subject.

Level of Study: Postgraduate

Type: Scholarship

Value: For Postgraduates up to a maximum of $£ 4,000$ per year for a full academic year. For Undergraduates up to a maximum of $£ 2,000$ per year for a full academic year

Length of Study: 1 year

Frequency: Annual

Study Establishment: Cranfield University, School of Applied

Sciences

Country of Study: United Kingdom

No. of awards offered: $5-10$

Application Procedure: Please check the website www.sut.org.uk. Closing Date: July 29th

Funding: Corporation

Contributor: SUT

Additional Information: Applications are to be sent by post not electronically.

For further information contact:

SUT, 80 Coleman Street, London

\section{Utilities and Service Industries Training (USIT)}

Subjects: Economics for natural resources and environmental management, environmental diagnostics and management, environmental management for business, water and wastewater engineering, water management and environmental engineering.

Purpose: To support students attending an established academic course in the UK, which is relevant to one water utility industry. To assist individuals to benefit from opportunities that would not normally be available to them from employer's.

Eligibility: This award is open to any individual employed in the UK utilities sector to participate on the above course.

Level of Study: Postgraduate

Type: Award

Value: Up to $£ 7,500$

Length of Study: 1 year

Frequency: Annual

Study Establishment: Cranfield University, School of Applied

Sciences

Country of Study: United Kingdom

Application Procedure: Application form can be downloaded from the website www.usit.org.uk. Applicants must submit a short paper to support the application.

Closing Date: Please refer to website for details

Funding: Foundation

Contributor: USIT

No. of applicants last year: Many high competition 


\section{Water MSc Scholarship for Students from Malawi and} Vietnam

Purpose: The aim of the scholarship is to recruit students across all of our areas of academic specialisms with expertise in a wide range of disciplines to pursue MSc programme.

Eligibility: The scholarship is open to students from Malawi and

Vietnam.

Level of Study: Postgraduate

Value: The Cranfield Water Scholarship provides funding of $£ 6,000$ towards tuition fees

No. of awards offered: Up to 4 scholarships are available Closing Date: May 25th

\section{Women as Cyber Leaders Scholarship}

Subjects: Science, engineering, technology and management. Purpose: For female students wishing to develop a career in Cyber.

Level of Study: Postgraduate

Type: Postgraduate scholarships

Value: $£ 6,500$ toward tuition fees

Country of Study: United Kingdom

No. of awards offered: Not known

Application Procedure: For eligibility and application details, please visit website https://www.cranfield.ac.uk/funding/fundingopportunities/women-as-cyber-leaders-scholarship.

Closing Date: June 30th

Contributor: Cranfield Defence and Security

\section{CRIMINOLOGY RESEARCH COUNCIL (CRC)}

GPO Box 2944, Canberra, ACT 2601, Australia

Tel: (61) 262609216

Fax: (61) 262609218

Email: crc@aic.gov.au

Website: www.criminologyresearchcouncil.gov.au

Contact: Miss Katalina Bradley, Administrator

The Criminology Research Council (CRC) funds methodologically sound research in the areas of sociology, psychology, law, statistics, police, judiciary, corrections, mental health, social welfare, education and related fields. The research to be conducted is policy-orientated, and research outcomes should have the potential for application nationally or in other jurisdictions.

\section{CRC Grants}

Subjects: Criminological research in the areas of sociology, psychology, law, statistics, police, judiciary and corrections, etc. From time to time the Council will call for research in specific areas.

Purpose: To support research in Australia.

Eligibility: Open to Australian residents or visitors (actual or intending) who are pursuing or intend to pursue studies of consequence to the furtherance of criminological research in Australia. Grants are not likely to be given for assistance with research leading to the award of postgraduate degrees.

Level of Study: Doctorate, Postdoctorate

Type: Grant

Value: Varies

Length of Study: Usually 1 year, with a possibility of renewal for up to 3 years

Frequency: Annual

Country of Study: Australia

No. of awards offered: Approx. 6

Application Procedure: Applicants must complete an application form, available from the CRC.

Closing Date: August 14th

Funding: Government

No. of awards given last year: 3

No. of applicants last year: 45

Additional Information: Please check website for more details about new grants at www.crc.nsw.gov.au/grants. There are many changes in the existing grant so please refer website for updates.

\section{THE CROHN'S AND COLITIS FOUNDATION OF AMERICA}

733 Third Avenue, Suite 510, New York, NY, 10017, United States of America

Tel: (1) 8009322423

Fax: (1) 2127794098

Email: info@ccfa.org

Website: www.ccfa.org

Contact: Ms Joseph O'Keefe, Director of Grants Administration

The Crohn's and Colitis Foundation of America is a non-profit, voluntary health organization dedicated to improving the quality of life for persons with Crohn's disease or ulcerative colitis. It supports basic and clinical scientific research to find the causes and cure for these diseases, provides educational programmes for patients, medical and healthcare professionals and the general public, alongside offering supportive services to patients, their families and friends.

\section{Crohn's and Colitis Foundation Career Development Award \\ Subjects: Crohn's disease and ulcerative colitis.}

Purpose: To stimulate and encourage innovative research that is likely to increase our understanding of the aetiology, pathogenesis, therapy and prevention of Crohn's disease and ulcerative colitis (IBD). Eligibility: Candidates should hold an MD and must have 5 years of experience (with 2 years of research relevant to IBD).

Level of Study: Postdoctorate, Research

Type: Award

Value: Not to exceed US\$90,000 per year

Length of Study: 1-3 years

Study Establishment: An approved research institute

Country of Study: United States of America

No. of awards offered: Varies

Application Procedure: The full application must be submitted electronically via proposal central and paper (master) of the full application must be sent to the CCFA National office.

Closing Date: January 1st (Fall/Winter) or July 1st (Spring/Summer) Funding: Individuals, private, trusts, corporation, foundation No. of awards given last year: 10

No. of applicants last year: 51

Additional Information: Please check complete information at www.ccfa.org/science-and-professionals/research/grants-fellowships/ career-development-awards.html.

For further information contact:

Crohn's \& Colitis Foundation of America, Research and Scientific Programs Department, 386 Park Avenue South, 17th Floor, New York, NY 10016-8804

\section{Crohn's and Colitis Foundation Research Fellowship Awards}

Subjects: Crohn's disease and ulcerative colitis (IBD).

Purpose: To stimulate and encourage innovative research that is likely to increase our understanding of the aetiology, pathogenesis, therapy and prevention of Crohn's disease and ulcerative colitis (IBD) Eligibility: Applicants must hold an MD, $\mathrm{PhD}$, or equivalent with at least 2 years of research experience.

Level of Study: Postdoctorate, Research

Type: Award

Value: up to $\$ 58,250$ per year (subject to annual progress report approval)

Length of Study: 1-3 years

Frequency: Annual

Study Establishment: An approved research institute

Country of Study: United States of America

Application Procedure: The full application must be submitted electronically via the IGAM and paper (master) of the full application must be sent to the CCFA National office.

Closing Date: January 1st and July 1st

Funding: Corporation, foundation, individuals

Crohn's and Colitis Foundation Senior Research Award Subjects: Crohn's disease and ulcerative colitis (IBD).

Purpose: To stimulate and encourage innovative research that is likely to increase our understanding of the aetiology, pathogenesis, 
therapy and prevention of Crohn's disease and ulcerative colitis (IBD).

Eligibility: Applicant must hold an MD and/or PhD (or equivalent degree) and must be employed by an institution (public non-profit, private non-profit, or government) that is engaged in health care and/or healthrelated research. He/she must have attained independence from his/her mentor. Eligibility is not restricted by citizenship or geography.

Level of Study: Postdoctorate, Research

Type: Research award

Value: Total maximum award per year: $\$ 115,830$ (subject to annual progress report approval)

Length of Study: 1-3 years

Frequency: Annual

Study Establishment: An approved research institute

Country of Study: Any country

Application Procedure: The full application must be submitted electronically via the IGAM and paper (master) of the full application must be sent to the CCFA National office.

Closing Date: Spring - November 1st (LOI); January 14th (application submission)/Fall - May 1st (LOI); July 1st (application submission)

Funding: Corporation, foundation, individuals

\section{Crohn's and Colitis Foundation Student Research \\ Fellowship Awards}

Subjects: Crohn's disease and ulcerative colitis (IBD).

Purpose: To stimulate and encourage innovative research that is likely to increase our understanding of the aetiology, pathogenesis, therapy and prevention of Crohn's disease and ulcerative colitis (IBD). Eligibility: Candidates may be undergraduate, medical, or graduate students (not yet engaged in thesis research) in accredited U.S. institutions. Candidates may not hold similar salary support from other agencies.

Level of Study: Graduate, Postgraduate, Research

Type: Award

Value: Up to US\$2,500 per year

Length of Study: At least 10 weeks

Frequency: Annual

Study Establishment: An approved research institute

Country of Study: United States of America

No. of awards offered: Up to 16

Application Procedure: The full application must be submitted electronically via the IGAM and paper (master) of the full application must be sent to the CCFA National office.

Closing Date: Spring - March 15th (online application submission) Funding: Corporation, foundation, individuals

Additional Information: Before submitting a Full Proposal, please view the Student Research Fellowship Award Policies (.pdf) and Instructions (.pdf) at www.ccfa.org/science-and-professionals/ research/grants-fellowships/student-research-awards.html.

\section{THE CROSS TRUST}

PO Box 17, 25 South Methven Street, Perth, Perthshire, PH1 5ES, Scotland

Tel: (44) 1738620451

Fax: (44) 1738631155

Email: crosstrust@mccash.co.uk

Website: www.thecrosstrust.org.uk

Contact: Ms Kathleen Carnegie, Assistant Secretary

The aim of the Cross Trust is to provide opportunities to young people of Scottish birth or parentage to extend the boundaries of their knowledge of human life. Proposals are to be of demonstrable merit from applicants with a record of academic distinction.

\section{Cross Trust Grants}

Subjects: Any approved subject.

Purpose: To enable young of Scottish birth or parentage people to extend the boundaries of their knowledge of human life.

Eligibility: Open to applicants of Scottish birth or parentage and must demonstrate thesis.

Level of Study: Unrestricted

Type: Grant

Value: Varies

Length of Study: Varies
Frequency: Annual

Study Establishment: An approved institute

Country of Study: Any country

No. of awards offered: Varies

Application Procedure: Applicants must complete an application form.

Closing Date: There may only be three meetings. Please check

deadlines on website.

Funding: Private

No. of awards given last year: 121

No. of applicants last year: 198

Additional Information: Awards will only be considered from postgraduate students who have part funding in place from another organization. The Trust may support the pursuit of studies or research

For further information contact:

McCash \& Hunter, 25 South Methven Street, Perth, Perthshire, PH1 5PE, Scotland

Website: www.crosstrust.org.uk

Contact: The Secretaries

\section{THE CROUCHER FOUNDATION}

\author{
Suite 501, Nine Queen's Road Central, Hong Kong \\ Tel: (852) 27366337 \\ Fax: (852) 27300742 \\ Email: cfadmin@croucher.org.hk \\ Website: www.croucher.org.hk \\ Contact: Ms Elaine Sit, Administrative Officer
}

Founded to promote education, learning and research in the areas of natural sciences, technology and medicine, the Croucher Foundation operates a scholarship and fellowship scheme for individual applicants who are permanent residents of Hong Kong wishing to pursue doctoral or postdoctoral research overseas. The Foundation otherwise makes grants to institutions only.

\section{Croucher Foundation Fellowships and Scholarships}

Subjects: Natural sciences, medicine and technology.

Purpose: To enable selected students of outstanding promise to devote themselves to full-time postgraduate study or research in approved academic institutions outside Hong Kong.

Eligibility: Open to permanent residents of Hong Kong. Fellowships are intended for recent PhD graduates and not for the funding of career vacancies in universities. Scholarships are intended for those undertaking $\mathrm{PhD}$ studies or final year undergraduate students who are expected to obtain first class honours or equivalent degrees.

Level of Study: Doctorate, Postdoctorate

Type: Scholarships, fellowships

Value: US $\$ 48,240$ per year for fellowships, and US\$30,300 per year and tuition fees for scholarships, plus airfare assistance and other allowances

Length of Study: 1-2 years for fellowships, 1-3 years for scholarships

Frequency: Annual

Country of Study: Outside Hong Kong

No. of awards offered: Approx. 20-25

Application Procedure: Applicants can apply online at www.

croucher.org.uk in late September.

Closing Date: November 15th

Funding: Private

No. of awards given last year: 17

No. of applicants last year: About 100

Additional Information: Eligible to permanent residents of Hong Kong only.

\section{CUD (BELGIAN UNIVERSITY COMMISSION FOR DEVELOPMENT) ARES (ACADEMY OF RESEARCH AND HIGHER EDUCATION)}

Rue Royale 180, 1000 Brussels, Belgium

Website: http://www.ares-ac.be/en/cooperation-au-developpement/ bourses/masters-et-stages-en-belgique Contact: ARES 


\section{ARES Scholarships}

Subjects: Aquaculture, health, food technology, economics, international development, GIS, information technology, agriculture, environment, human rights, microfinance.

Level of Study: Postgraduate

Eligibility: The scholarships are for nationals of: Benin, Bolivia, Burkina Faso, Burundi, Cambodia, Cameroon, Cuba, Ecuador, Ethiopia (only for courses in English), Haiti, Madagascar, Morocco, Niger, Peru, Philippines, DR Congo, Rwanda, Senegal, Vietnam.For more details, please visit official scholarship website: http://www.aresac.be/en/cooperation-au-developpement/bourses/masters-et-stagesen-belgique.

Value: The scholarship covers international travel expenses, living allowance, tuition fees, insurance, housing allowance

No. of awards offered: 150 Masters scholarships and 70 training scholarships

Application Procedure: To apply for the scholarship, complete the single form scholarship application and admission to one of the French-speaking universities of Belgium.

Closing Date: January 13th

\section{THE CULINARY INSTITUTE OF AMERICA (CIA)}

1946 Campus Drive, Hyde Park, New York, NY, 12538, United States of America

Tel: (1) 8454529430

Fax: (1) 8454511068

Email: admissions@culinary.edu

Website: www.ciachef.edu

The Culinary Institute of America (CIA) is a private, non-profit college dedicated to providing the world's best professional culinary education. $\mathrm{CIA}$ has been setting the standard for excellence in professional culinary education. The faculty, facilities, and academic programmes are offered at our campuses in Hyde Park, New York and St Helena, California.

\section{CIA ACAP Merit-based Scholarship}

Purpose: The CIA seeks students who have demonstrated academic excellence and leadership qualities.

Eligibility: Students from select hospitality baccalaureate programs who are recommended to ACAP by their program dean, director, or faculty member are eligible for this scholarship and will be automatically selected for this award based on their letter of recommendation.

Type: Scholarship

Value: US\$3,500-6,500

Frequency: Annual

Study Establishment: The Culinary Institute of America

Country of Study: United States of America

No. of awards offered: 1

Application Procedure: For a listing of eligible bachelor's degree programs, interested students should call 707967 2496. Scholarships are available for those who qualify and are awarded to students identified through the admissions process; a separate scholarship application is not necessary

Closing Date: Contact institute

Funding: Private

Additional Information: Please check at www.ciachef.edu/californiacampus-scholarships/ for more updated information.

\section{THE CULINARY TRUST}

PO Box 5485, Portland, OR, 10013, United States of America Tel: (1) 972285485

Email: scholarships@theculinarytrust.org Website: www.theculinarytrust.org/

The Culinary Trust has been the philanthropic partner to over 4,000 members of the International Association of Culinary Professionals (IACP) for over 20 years. The Trust solicits, manages and distributes funds for educational and charitable programmes related to the culinary industry in many areas.
Centro Culinario Ambrosia Mexican Cuisine Scholarship

Subjects: Mexican cuisine.

Purpose: To provide continuing education in Mexican cuisine.

Eligibility: Open to an experienced cook.

Level of Study: Unrestricted

Type: Scholarship

Value: Includes tuition, supplies, uniforms, and cutlery

Length of Study: 15 weeks

Frequency: Annual

No. of awards offered: 1

Application Procedure: Check website for further details.

Additional Information: Scholarship is valid from July 1st. Transportation and accommodations are not provided.

For further information contact:

Website: www.ambrosia.com.mx

\section{Cuisinart Culinary Arts Scholarship}

Subjects: Cuisine art.

Purpose: To provide financial assistance to individuals interested in preparing for a career in the culinary arts.

Eligibility: Check website for further details.

Level of Study: Unrestricted

Type: Scholarship

Value: Open to student enroled in a Culinary Certificate or Degree programme at any nationally accredited culinary school

Length of Study: $\$ 1,500$

Frequency: Annual

No. of awards offered: 1

Application Procedure: Scholarship valid from July 1st.

Closing Date: See the website

For further information contact:

Website: www.cuisinart.com

\section{Culinary Arts Scholarship}

Subjects: Culinary arts.

Purpose: To offer an assortment of funding opportunities available for the educational pursuits of beginning and/or currently enroled culinary students as well as long-time culinary professionals seeking funding for continuing education short-courses and/or conducting independent study and research.

Eligibility: Open to a candidate who has pre-enroled toward the 6-10 month Culinary Arts or Pastry \& Baking Arts Diploma Program. Type: Scholarship

Value: $\$ 5,000$

Length of Study: 6-10 months

Frequency: Annual

Study Establishment: The Institute of Culinary Education New York No. of awards offered:

Application Procedure: Check the website for further information. Closing Date: Check the website

Additional Information: Scholarship may only be awarded to a student prior to their enrollment at The Institute of Culinary Education.

For further information contact:

Admissions Department, Institute of Culinary Education (ICE)

Tel: 2128470757

Website: www.iceculinary.com

Harry A. Bell Travel Grant

Subjects: Culinary research.

Purpose: For travel and research to food writers during the precontract phase of their book proposal.

Eligibility: Open to writers who are in the pre-contract phase of their book.

Level of Study: Unrestricted

Type: Grant

Value: $\$ 3,000-4,000$

Frequency: Annual

No. of awards offered: Varies

Application Procedure: Check the website for further details.

Closing Date: May 31st

For further information contact:

Website: www.theculinarytrust.com 


\section{The Julia Child Endowment Fund Scholarship}

Subjects: Culinary arts.

Purpose: To support a career professional to conduct independent study and research in France, as it relates to French food, wine, history, culture and traditions. This programme also encourages, enables and assists aspiring students and career professionals to advance their knowledge of the culinary arts.

Eligibility: Open to applicants who have 2 years of food service experience.

Level of Study: Professional development

Type: Scholarship

Value: US $\$ 5,000$

Frequency: Annual

Country of Study: France

Application Procedure: Applicants are required to include a threepage project proposal, an itemized budget detailing the use of this award, a tentative travel schedule with dates and locations, and provide a current curriculum vitae to qualify for this scholarship.

Closing Date: December 15th

Funding: Trusts

Additional Information: Please check website for more details.

\section{The Julia Child Fund at the Boston Foundation}

\section{Independent Study Scholarship}

Subjects: French food, wine and culinary art.

Purpose: For independent study in France on French food, wine and culinary disciplines.

Eligibility: Open to a career professional doing research in writing and teaching related to French food, wine, and culinary disciplines. Level of Study: Professional development

Type: Scholarship

Value: $\$ 5,000$

Frequency: Annual

Country of Study: France

No. of awards offered: 1

Application Procedure: Applicants are required to include a threepage project proposal, an itemized budget detailing the use of this award, a tentative travel schedule with dates and locations, and provide a current curriculum vitae to qualify for this scholarship. Closing Date: Please check the website

Additional Information: Please check website for more details.

\section{L'Academie de Cuisine Culinary Arts Scholarship}

Subjects: Culinary arts.

Purpose: To financially prospective students prospective students for the Culinary Arts Program each year.

Eligibility: Open to a student pre-enroled for the 12 months, Culinary Arts or Pastry Arts Certificate Program.

Type: Scholarship

Value: $\$ 5,000$

Length of Study: 1 year

No. of awards offered: 1

Application Procedure: Check the website for further details.

Closing Date: December

Additional Information: Scholarship is valid for enrollment during July or October only.

For further information contact:

Tel: 6462246989

Email: scholarships@theculinarytrust.org

Website: www.lacademie.com, www.theculinarytrust.org

Contact: Amy Blackburn, Director of Administration for The Culcinary Trust

\section{Zwilling, J.A. Henckels Culinary Arts Scholarship}

Subjects: Culinary arts.

Purpose: To provide financial assistance to students from designated states who are interested in pursuing a degree in the culinary arts.

Eligibility: Open to any pre-enroled student, currently enroled student or career professional toward any culinary arts degree or certificate program at any nationally accredited culinary school.

Level of Study: Postgraduate

Type: Scholarship

Value: $\$ 5,000$

No. of awards offered: 1
Application Procedure: Check the website for further details. Closing Date: December 15th

Contributor: Zwilling, J.A. Henckels Trust

For further information contact:

Email: scholarships@theculinarytrust.org Website: www.jahenckels.com

\section{CULTURAL VISTAS}

440 Park Avenue South, 2nd Floor (between 29th and 30th Streets), New York, NY, 10016, United States of America

Tel: (1) 2124973500

Fax: (1) 2124973535

Email: info@culturalvistas.org

Website: www.culturalvistas.org/

CDS International, Inc. is a non-profit organization that administers work exchange programmes. CDS International's goal is to further the international exchange of knowledge and technological skills, and to contribute to the development of a pool of highly trained and interculturally experienced business, academic and government leaders.

\section{Alfa Fellowship Program}

Subjects: Business, economics, journalism, law and public policy. Purpose: To expand networks of American, British and Russian professionals and develop greater intercultural understanding and advancing US/Russian and British/Russian relations.

Eligibility: U.S. or British citizen; 25-35 years old at the application deadline; Russian proficiency is preferred; qualified candidates with fluency in a second language may be considered; graduate-level degree or equivalent training in business, economics, journalism, law, public policy or government; a least 2 years of relevant work experience.

Level of Study: Graduate

Type: Fellowship

Value: Travel, free housing, monthly stipends, and insurance

Frequency: Annual

Application Procedure: Applicants must submit an application form Closing Date: December 1st

Funding: Private

\section{Baden-Württemberg Stipendium 'Work Immersion Study Program' (WISP)}

Subjects: All subjects.

Purpose: To support students to gain practical work experience in their career field, improve their German language skills and experience German culture firsthand.

Eligibility: Candidates for WISP must meet the following eligibility requirements: U.S. citizen or permanent resident; 18-27 years of age one semester of German instruction by program start; enroled in an associate degree program at a community or technical college at the time of application; minimum of 1 year of study toward associate degree completed by program start; prior experience in target internship field through a summer or part-time job, volunteer position, or prior internship.

Value: Monthly stipend of $€ 300$. See www.cdsintl.org/fellowshipsabroad/wisp.php for more details

Length of Study: 3 months

Frequency: Annual

Application Procedure: Applicants must submit an online application form.

Closing Date: December 1st

Funding: Private

\section{Congress Bundestag Youth Exchange for Young Professionals}

Subjects: Business, technical, computer science, social and service fields.

Purpose: To foster the exchange of knowledge and culture between German and American youth, while providing career-enhancing theoretical and practical work experience.

Eligibility: Open to citizens of the USA and permanent residents aged 18-24 years who have well-defined career goals and related part or 
full-time work experience. Applicants must be able to communicate and work well with others, have maturity enabling them to adapt to new situations, an intellectual curiosity and a sense of diplomacy. Level of Study: Professional development

Type: Scholarship

Value: Full-year scholarship including international airfare and partia domestic transportation, language training and study at a German professional school, seminars, including transportation and insurance, host family stay

Length of Study: 1 year: 2-month language; 4-month study; 5-month internship

Frequency: Annual

Study Establishment: A field-specific postsecondary professional school

Country of Study: Germany

No. of awards offered: 75

Application Procedure: Apply online at www.cdsintl.org/cbyx.

Closing Date: December 1st

Funding: Government

Contributor: U.S. Congress and German Bundestag

No. of awards given last year: 75

No. of applicants last year: $250-350$

Additional Information: Participants must have US\$300-350 pocket money per month. During the year of the award, American exchange students will have the opportunity to improve their skills through forma study and work experience. The programme also includes intensive language instruction and housing with a host family or in a dormitory.

\section{Émigré Memorial German Internship Program}

Subjects: EMGIP is ideal for students planning on pursuing careers at a regional level of government in the US or Canada, or who have an interest in a specific policy issue such as the environment, education and/or healthcare.

Purpose: To support students to gain government work experience, improve their advanced German language skills and learn about German culture firsthand.

Eligibility: Candidates for EMGIP must meet the following eligibility requirements: US or Canadian citizen; undergraduate and graduate students enroled at accredited American or Canadian colleges and universities before, during and after the program may apply. U.S. citizens who have graduated are also eligible, so long as their internships begin within 3 months of graduation; 18-30 years of age; high-intermediate German skills (oral and written). Candidates must be able and willing to communicate in German and possess a good command of professional vocabulary in their field; minimum of 2 years of university level studies in a field related to one of the following: international relations, public administration, political science, law, economics, European studies with an emphasis on Germany, German or German Studies, with a minor in one of the fields listed here; some relevant work experience (e.g. internship, volunteer work, summer job). It is important that a candidate knows how to adjust to a professional environment and how to use theoretical skills in the workplace.

Level of Study: Graduate, Unrestricted

Type: Internship

Value: Monthly stipends to ensure a total monthly salary of $€ 670$ for US citizens (Please note: monthly stipends for Canadian citizens cannot be guaranteed-this is dependent on the Landtag). This will cover basic expenses such as housing, local transportation and food

Length of Study: 1-3 months

Frequency: Thrice a year

Application Procedure: Applicants must submit an online application form.

Closing Date: October 1st for Spring; December 1st for early

Summer; March 31st for Fall

Funding: Private

\section{Robert Bosch Foundation Fellowship Program}

Subjects: Business administration, journalism, law, public policy and closely related fields.

Purpose: To support young Americans the opportunity to complete a high-level professional development program in Germany.

Eligibility: Candidates for the Robert Bosch Foundation Fellowship

Program must meet the following requirements: U.S. citizen; 23-34 years old at the application deadline; at least 2 years of relevant work experience; graduate degree or equivalent training in business administration, journalism, law, public policy, international relations or a closely related field; evidence of outstanding professional performance and community involvement; no German language skills are required at time of application; however, the willingness and commitment to participate in language training based on the results of an evaluation at the selection meeting is essential; most Bosch fellows are required to complete 4 months of private tutoring in the US (up to 8 hours per week) and 3 months of intensive language training in Berlin prior to the start of the program. All language training is funded by Robert Bosch Stiftung

Level of Study: Graduate, Unrestricted

Type: Fellowship

Value: $€ 2,000$ per month stipend. See www.cdsintl.org/fellowshipsabroad/bosch.php for more details

Length of Study: 9 months

Frequency: Annual

No. of awards offered: 20

Application Procedure: Application form and supporting documents

Closing Date: October 15th

Funding: Private

\section{For further information contact:}

Email: bosch@culturalvistas.org

Website: http://culturalvistas.org/programs-for-students-and-

professionals/professional-fellowships/robert-bo

\section{Transatlantic Renewable Energy Fellowship}

Subjects: Environmental and energy fields.

Purpose: To build an international network of future leaders in renewable energy and environmental fields as well as to increase transatlantic cooperation on climate and energy issues.

Eligibility: Candidates must be enroled in a U.S. university or be a U.S. citizen; must be 32 years old or younger at the application deadline; at least 3 years of study in one of the following fields: technical fields (electrical, industrial and mechanical engineering; information technology; production, manufacturing, logistics and supply chain management; geography; and meteorology); sciences (physics, material sciences and chemistry); design and development (regional and urban planning; architecture); liberal arts (international relations, environmental policy and environmental economics); business (general business administration, international business and public relations); 2 years of experience in renewable energy or a related field, preferably in a professional capacity. Should be able to demonstrate initiative and ambassadorial skills.

Level of Study: Graduate

Type: Scholarship

Value: Fellows will receive $€ 1,100$ monthly (for 3 months) as well as an international travel allowance up to $€ 500$, a travel allowance in

Germany up to $€ 200$, insurance, and all seminar-related costs

Frequency: Annual

Application Procedure: Applicant must submit an online application form.

Closing Date: May

Funding: Private

Additional Information: Please check website for updated information.

\section{CURTIN UNIVERSITY OF TECHNOLOGY}

Office of Research and Development, GPO Box U1987, Perth, Western Australia, 6845, Australia

Tel: (61) 892667331

Fax: (61) 892662605

Email: research_scholarships@curtin.edu.au Website: http://www.curtin.edu.au/

Curtin University of Technology is a world class, internationally focused, culturally diverse institution. They foster tolerance and encourage the development of the individual. Their programmes centre around the provision of knowledge and skills to meet industry and workplace standards. A combination of first rate resources, staff and technology makes Curtin a forerunner in tertiary education both within Australia and internationally. 


\section{APA(I) - Innovation, Competition and Economic Performance}

Subjects: Computing/Information Technology (IT) and Economics/ Finance.

Purpose: To encourage students to undertake a Higher Degree by Research within the the Centre for Research in Applied Economics (CRAE).

Eligibility: Candidates must be Australian citizens or permanent residents or New Zealand citizens, should hold or are expected to hold a First Class Honours Degree or its equivalent and must meet Curtin University of Technology's requirements for admission to a PhD.

Level of Study: Graduate

Type: Competition

Value: Australian $\$ 25,118$ per year

Length of Study: 3 years with the possibility of an extension of up to 6 months

No. of awards offered: 1

Application Procedure: Candidates must forward the completed application for admission to a higher degree by research to the Centre for Research into Applied Economics (CRAE).

Closing Date: March 31st

For further information contact:

Tel: 61892662035

Email: H.Bloch@exchange.curtin.edu.au

Contact: Professor Harry Bloch

\section{Australian Biological Resources Study Postgraduate Scholarship \\ Subjects: Agricultural science.}

Purpose: To foster research training compatible with ABRS and national research priorities.

Eligibility: Applicants must be Australian citizens or permanent residents, must hold a First or Upper Second Class Honours or equivalent degree in an appropriate discipline and be enroled as a fulltime student in a PhD degree at an Australian institution.

Level of Study: Graduate

Type: Scholarship

Value: Australian $\$ 22,500$

Country of Study: Australia

No. of awards offered: 1

Application Procedure: Applicants must submit the application to ABRS through the host institution. The application form will then be submitted to the ABRS Advisory Committee for consideration and assessment using the selection criteria. The individual selected as most worthy of funding will be awarded the scholarship.

Closing Date: October 26th

For further information contact:

Australian Biological Resources Study, GPO Box 787

Tel: 0262509554

Fax: 0262509555

Email: abrs.grants@environment.gov.au

Contact: Business Manager

\section{Civil and Structural Engineering PhD Scholarship for International Students}

Subjects: Scholarship is awarded within the Faculty of Engineering in Civil and Structural Engineering.

Purpose: The Curtin University is currently accepting applications for civil and structural engineering PhD scholarship. Australian permanent resident, australian citizen, permanent humanitarian visa, international students and New Zealand Citizens are eligible to apply for this scholarship.

Eligibility: Australian permanent resident, australian citizen, permanent humanitarian visa, International students and New Zealand Citizens are eligible to apply for this scholarship. The candidate should have a very good command of English language. Therefore, the application should be written in English.

Level of Study: Postgraduate

Type: Postgraduate scholarships

Value: The successful student shall receive a stipend valued $\$ 27,082.00$ (2018) per annum. The duration of the scholarship shall be for 3 years with a possible extension of up to 6 months provided the student meets eligibility guidelines as per the conditions of the award If the successful candidate is an international student, the scholarship shall cover tuition fees for the duration of the award.

Study Establishment: Scholarship is awarded within the Faculty of Engineering in Civil and Structural Engineering

Country of Study: Australia

No. of awards offered: Not known

Application Procedure: Please send your expression of interest together with your CV, English testing score and transcripts via email to Dr. Chen (wensu.chen-at-curtin.edu.au).

Closing Date: Applications accepted at any time

Additional Information: For more details please visit the website http://scholarship-positions.com/civil-structural-engineering-phd-scholarship-international-students-australia/2018/01/15/.

\section{Curtin Business School Doctoral Scholarship}

Subjects: Economics/finance, human resources, legal studies/politics, management/administration, marketing/public relations.

Purpose: To enable doctoral (PhD, DBA) students to study at the Curtin Business School.

Eligibility: Applicants must have completed at least 4 years of tertiary education studies at a high level of achievement and have First/Upper Second Class Honours or equivalent results. See http://scholarships. curtin.edu.au/scholarship.cfm?id $=52$ for more details

Level of Study: Postgraduate

Type: Scholarship

Value: $\$ 25,000$

Length of Study: Up to 3 years

Frequency: Annual

No. of awards offered: 3

Application Procedure: Applicants can download the application form and obtain further information from the website.

Closing Date: December 31st

For further information contact:

Tel: 0892664301

Email: j.boycott@curtin.edu.au

Contact: Ms Jo Boycott, Research Student Coordinator

\section{Curtin International Merit Scholarship in Australia}

Eligibility: Open to international students. This scholarship is only for: international, full fee-paying, non-sponsored students; students who apply through a Curtin registered agent - if you have not applied through a registered agent, you are not eligible for this scholarship; students commencing a full Curtin undergraduate or masters by coursework program.

Level of Study: Postgraduate

Type: Scholarship

Value: This scholarship category awards eligible students 25 per cent of their first year of tuition

Frequency: Annual

Country of Study: Australia

Application Procedure: Students are invited to apply as normal for their chosen undergraduate or masters program through any one of Curtin University registered education agents: http://international. curtin.edu.au/apply/agents/search/.

Closing Date: February 12th

Additional Information: Please check complete information at http:// scholarships.curtin.edu.au/scholarships/scholarship.cfm?id=2034.0.

\section{Curtin University Postgraduate Scholarship (CUPS)}

Subjects: All subjects.

Purpose: To assist with general living costs.

Eligibility: Applicants must be Australian or New Zealand citizens or Australian permanent residents and must have completed 4 years of higher education studies at a high level of achievement and must hold, or are expected to obtain, First Class Honours or equivalent results; be enroled in or accepted to enrol in a Higher Degree by Research as a full-time student in the previous year in which the award is to be given.

Level of Study: Postgraduate, Graduate

Type: Scholarship

Value: Varies, an annual living allowance of $\$ 23,728$ was given last year. This stipend is indexed annually and is tax-free unless taken on a part-time basis. 
Length of Study: 2 years for a Master by Research and 3 years, with a possible extension of up to 6 months, for a Doctoral degree

No. of awards offered: 40

Application Procedure: Check website for further details.

Closing Date: October 31st

For further information contact:

Tel: 0892664906

Fax: 0892663793

Email: research_scholarships@curtin.edu.au

Website: http://scholarships.curtin.edu.au

Contact: Manager, Scholarships

\section{Establishing the Source of Gas in Australia's Offshore \\ Petroleum Basins Scholarship}

Subjects: Chemistry, geochemistry, geology.

Purpose: To develop an isotopic method to analyse gases in fluid inclusions and to establish the source of gas in Australia's offshore petroleum basins.

Eligibility: Applicants must have First Class Honours or equivalent science degree, preferably in chemistry/geology/geochemistry. Interests in analytical organic chemistry, laboratory skills in trace analysis, wet chemical methods, GC/GCMS or GC-IRMS instrumentation and awareness of stable isotopic concepts is desirable.

Level of Study: Postgraduate

Type: Scholarship

Value: At least $\$ 20,000$ per year

No. of awards offered: 1

Application Procedure: Check website for further details.

Closing Date: December 31st

Contributor: The Stable Isotope and Molecular Biogeochemistry

Research Group, Geoscience Australia, GFZ

For further information contact:

Stable Isotope and Molecular Biogeochemistry Group, Centre for Applied Organic Geochemistry, Department of Applied Chemistry, Curtin University of Technology, GPO Box U1987, Perth, WA 6845

Tel: 610892662474

Fax: 610892662300

Email: K.grice@curtin.edu.au

Website: www.caog.chemistry.curtin.edu.au

Contact: Professor Kliti Grice

\section{French-Australian Cotutelle}

Subjects: All subjects.

Purpose: To support the development of the double doctoral degree 'Cotutelle' between Australia and France.

Eligibility: Applicants must be PhD students (of any nationality) enroled in a Cotutelle project between a French and an Australian university; should not have benefited from the French Embassy Cotutelle grant in previous years and should be registered with FEAST-France.

Level of Study: Postgraduate

Type: Grant

Value: $\$ 2,500$

No. of awards offered: 10

Application Procedure: Applicants must provide the French Embassy with the completed application form and a copy of the Cotutelle convention.

Closing Date: December 8th

For further information contact:

Higher Education Attache, Embassy of France in Australia Email: Stephane.GRIVELET@diplomatie.gouv.fr

Website: www.ambafrance-au.org

Contact: Mr Stephane GRIVELET

\section{The General Sir John Monash Awards}

Subjects: All subjects.

Purpose: To enable them to undertake postgraduate study abroad at the world's best Universities, appropriate to their field of study. Eligibility: Applicants must be Australian citizens who have graduated from an Australian University with outstanding levels of academic achievement.
Level of Study: Graduate

Type: Award

Value: Australian $\$ 60,000$ per year

Length of Study: 3 years

Frequency: Annual

No. of awards offered: 10

Application Procedure: Check website for further details.

Closing Date: Mid-August

For further information contact:

The General Sir John Monash Foundation, Level 1, Bennelong House, 9 Queen Street, Victoria, Melbourne, 3000, Australia

Tel: (61) 61396202428

Email: peter.binks@monashawards.org

Website: www.monashawards.org

Contact: Dr Peter Binks, Chief Executive Officer

\section{Gowrie Research Scholarship}

Subjects: All subjects.

Purpose: To assist members of the defence forces and direct descendants of members of the defence force to aid with their research study.

Eligibility: Candidates must be the Australian citizen or permanent resident and a graduate who have completed a course of tertiary education at other recognized Australian institutions.

Level of Study: Graduate

Type: Scholarship

Value: $\$ 4,000$ per year

Length of Study: 2 years

No. of awards offered: 1

Application Procedure: Candidates must submit applications in duplicate on the prescribed form. If space is insufficient, a separate statement should be added.

Closing Date: October 31st

Contributor: Gowrie Scholarship Trust Fund

For further information contact:

The Gowrie Scholarship Fund Trust, 3/32 Beaconsfield Road, Mosman, NSW 2088, Australia

Contact: The Secretary

\section{Hunter Postgraduate Scholarship}

Subjects: Alzheimer's disease.

Purpose: To support a PhD student undertaking research in an area relevant to understanding the causes of Alzheimer's disease.

Eligibility: Candidates must be PhD students undertaking research in an area relevant to understanding the causes of Alzheimer's disease.

Level of Study: Postgraduate

Type: Scholarship

Value: Up to $\$ 5,000$ towards fees subject to funds available

Length of Study: 1 years

No. of awards offered: One per year

Application Procedure: Check website for further details. Closing Date: October 31st

For further information contact:

Tel: 0262547233

Email: aar@alzheimers.org.au

Contact: Anna Conn

\section{PhD Scholarship for Science Education Research}

Subjects: These scholarships are awarded in the field of humanities.

Purpose: The aim of the scholarships is to give excellent research experience to both Australian and international applicants.

Eligibility: Australian and International. Applicants must meet the necessary language requirement of the host institution.

Level of Study: Doctorate

Value: These scholarships will cover $\$ 27,082.00$ per annum for 3 years (2018 RTP rate)

Study Establishment: These scholarships are awarded in the field of Humanities

Country of Study: Australia

No. of awards offered: 2 
Application Procedure: Interested applicants please email an expression of interest with the CV and transcripts.

Closing Date: February 1st

Additional Information: For more details please visit the website http://scholarship-positions.com/phd-scholarship-science-educationresearch-curtin-university-australia/2018/01/24/.

\section{Scots Australian Council Scholarships}

Subjects: Humanities.

Purpose: To develop lasting links between young Scots and Australians by offering outstanding graduates and young professionals the opportunity to study at a Scottish university. Eligibility: Applicants must be Australian citizens or Australian permanent residents or New Zealand citizens or on permanent Humanitarian Visa. They must be indigenous or Torres Strait Islander students or students with a disability or students from rural or regional areas or mature students or sole parents or current students or prospective students.

Level of Study: Postgraduate

Type: Scholarship

Value: $£ 12,000$

No. of awards offered: 1

Application Procedure: Check website for further details.

Closing Date: January 14th

Contributor: Scottish universities, Scottish business and industry, British Foreign and Commonwealth Office

For further information contact:

The Scots Australian Council, 19 Dean Terrace, Edinburgh, EH4 1NL, Scotland

Email: scholarships@scotsoz.org

Contact: The Secretary

\section{Sediment and Asphaltite Transport by Canyon \\ Upwelling - Top Up Scholarship \\ Subjects: Chemistry, geochemistry and geology.}

Purpose: To investigate the role of upwelling currents in transporting material across the continental slope of the Morum Sub-Basin, southern Australia using an integrated geological, oceanographic, and organic geochemical approach.

Eligibility: Applicants must be Australian and New Zealand residents, First Class Honours or equivalent science degree holders, preferably in chemistry/geology/geochemistry. Interests in analytical organic chemistry, laboratory skills in trace analysis, wet chemical methods, GC/GCMS or GC-IRMS instrumentation; awareness of stable isotopic concepts is desirable.

Level of Study: Graduate

Type: Scholarship

Value: See the organization website

No. of awards offered: 1

Application Procedure: Applicants must forward their interests, curriculum vitae and names of two referees to Stable Isotope and Molecular Biogeochemistry Group, Centre for Applied Organic

Geochemistry, Department of Applied Chemistry.

Closing Date: See the organization website

Contributor: The Stable Isotope and Molecular Biogeochemistry

Research Group, Adelaide University, a petroleum industry partner

\section{For further information contact:}

Stable Isotope and Molecular Biogeochemistry Group, Centre for Applied Organic Geochemistry, Department of Applied Chemistry, Curtin University of Technology, GPO Box U1987, Perth, WA 6845 Tel: 610892662474

Fax: 610892662474

Email: K.grice@curtin.edu.au

Website: www.caog.chemistry.curtin.edu.au

Contact: Professor Kliti Grice

\section{Three-year Fully Funded PhD Scholarship in Public \\ Health}

Subjects: Scholarship is awarded to conduct health services research that focuses on health systems and implementation science at the School of Public Health.
Purpose: The Curtin University is offering 3-year fully-funded PhD scholarship in Public Health. The scholarship is awarded to conduct health services research that focuses on health systems and implementation science at the School of Public Health.

Eligibility: International students can apply for these scholarships. If English is not your first language then you will need to show that your English language skills are at a high enough level to succeed in your studies.

Level of Study: Doctorate

Value: The successful candidate will receive a stipend of $\$ 27,082$ per annum

Study Establishment: Scholarship is awarded to conduct health services research that focuses on health systems and implementation science at the School of Public Health

Country of Study: Australia

No. of awards offered: Not known

Application Procedure: The mode of applying is online.

Closing Date: April 9th

Additional Information: For more details please visit our website http://scholarship-positions.com/three-year-fully-funded-phd-scholarship-public-health-australia/2018/02/27/.

\section{Water Corporation Scholarship in Biosolids Research}

Subjects: Agriscience and environmental science.

Purpose: To investigate the potential impacts to soil and plants following the agricultural land application of alum-dosed wastewater sludge. Eligibility: Applicants must be Australian Citizens, Australian permanent residents or must hold an Australian permanent Humanitarian Visa. They must hold a relevant degree from a recognized University in the preferred fields of Agriculture, Environmental Science or the equivalent and demonstrate a high level in their Honours project or equivalent.

Level of Study: Graduate, Postgraduate

Type: Scholarship

Value: $\$ 23,400$ per year

Length of Study: 3 years for a doctoral program and 2 years for a masters program

No. of awards offered: 1

Application Procedure: Check website for further details.

Closing Date: October 31st

For further information contact:

Muresk Institute, Perth

Email: D.Pritchard@curtin.edu.au

Contact: Dr Deborah Pritchard

\section{CYSTIC FIBROSIS CANADA (CFC)}

\author{
2221 Yonge Street, Suite 601, Toronto, ON, M4S 2B4, Canada \\ Tel: (1) 4164859149 \\ Fax: (1) 4164850960 \\ Email: info@cysticfibrosis.ca \\ Website: www.cysticfibrosis.ca \\ Contact: Program Director, Research Funding
}

Since 1960, the Cystic Fibrosis Canada (CFC) has worked to provide a brighter future for every child born with cystic fibrosis. Through its research and clinical programmes, CFC helps to provide outstanding care for affected individuals, while pursuing the quest for a cure or control.

\section{CCFF Clinic Incentive Grants}

Subjects: Cystic fibrosis.

Purpose: To enhance the standard of clinical care available to Canadians with cystic fibrosis, by providing funds to initiate a comprehensive programme for patient care, research and teaching or to strengthen an existing programme.

Eligibility: Canadian hospitals and medical schools are eligible to apply. Applicants must demonstrate the regional need for specialized clinical care for cystic fibrosis, the need of the institution for assistance and its plans to attract complementary funding from other sources to develop a complete cystic fibrosis programme, the potential for the development of a comprehensive programme for care, clinical research and teaching and the desire to collaborate with the CCFF and other Canadian cystic fibrosis clinics.

Level of Study: Research

Type: Grant 
Value: Honorarium and travel allowance

Length of Study: 1 year, renewable on an annual basis

Frequency: Annual

Country of Study: Canada

Application Procedure: Applicants must complete an application form. Late applications will be subject to a penalty equal to 10 per cent of the value of the award. This penalty will be deducted from the clinic director's honorarium.

Closing Date: October 1st

\section{CCFF Transplant Centre Incentive Grants}

Subjects: Cystic fibrosis.

Purpose: To enhance the quality of care available to cystic fibrosis transplant candidates by providing eligible centres with supplementary funding.

Eligibility: Open to any Canadian lung transplant centre that currently has one or more individuals with cystic fibrosis listed for transplant. Please note that under no circumstances will funding be provided to more than one transplant centre in the same city. Applicants must demonstrate how funds awarded would serve to enhance the quality of care available to patients in their centre.

Level of Study: Research

Type: Grant

Value: Determined in accordance with a formula that takes account of the number of patients assessed, accepted and followed preoperatively, transplanted and followed postoperatively in a given centre during the calendar year ending December 31 st of the year preceding the application

Length of Study: 1 year

Frequency: Annual

Country of Study: Canada

Application Procedure: Applicants must contact the Foundation. Applicants must provide a rationale for the funding request and a detailed report on patient care and research within the lung transplant programme. All applications will be adjudicated by the Clinic Subcommittee of the Canadian Cystic Fibrosis Foundation.

Closing Date: October 1st, please contact Foundation for update Additional Information: Late applications will be subject to a penalty equal to 10 per cent of the value of the award.

\section{CFC Fellowships}

\section{Subjects: Cystic fibrosis.}

Purpose: To support basic or clinical research training in areas of the biomedical or behavioural sciences pertinent to cystic fibrosis. Eligibility: Applicants must hold a PhD or MD. Medical graduates should have already completed basic residency training and must be eligible for Canadian licensure. Equitable consideration will be given to Fellowship applicants from outside of Canada, who intend to return to their own country on completion of a fellowship.

Level of Study: Postgraduate

Type: Fellowship

Value: Dependent upon academic qualifications and research experience

Length of Study: 2 years, renewable for up to 1 more year

Frequency: Annual

Study Establishment: An approved university department, hospital or research institute in Canada

Country of Study: Canada

Application Procedure: Applicants must arrange to send three letters of recommendation, one of which should be from the applicant's current or most recent supervisor.

Closing Date: October 1st

\section{CFC Research Grants}

Subjects: Cystic fibrosis.

Purpose: To facilitate scientific investigation of all aspects of cystic fibrosis.

Eligibility: A principal investigator should hold a recognized, full-time faculty appointment in a relevant discipline at a Canadian university or hospital. Under exceptional circumstances and at the discretion of the Scientific Peer Review Panel, applications from other individuals may be evaluated on a case-by-case basis.

Level of Study: Doctorate

Type: Research grant
Value: Determined by the Medical or Scientific Advisory Committee following a detailed review of the applicant's proposed budget Length of Study: Usually 1 or 2 years or, in a limited number of instances, 3 years

Frequency: Annual

Study Establishment: A Canadian institution

Country of Study: Canada

Application Procedure: Applicants must write for details. Incomplete or late applications will be returned to the applicant.

Closing Date: August 1st (Notice of intent to apply) and October 1st (application deadline)

Funding: Foundation

Additional Information: Investigators are eligible to hold more than one Research Grant. No more than one initial application may be submitted to a single competition, and it is a requirement that the focus of a second grant be clearly delineated from the first one. The specific aims of a second grant should represent new approaches to the cystic fibrosis problem and not an extension of an existing research programme.

\section{CFC Scholarships}

Subjects: Cystic fibrosis.

Purpose: To provide salary support for a limited number of exceptional investigators, offering them an opportunity to develop outstanding cystic fibrosis research programmes, unhampered by heavy teaching or clinical loads. Intended to attract gifted investigators to cystic fibrosis research.

Eligibility: Open to holders of an MD or PhD degree who are sponsored by the Chairman of the appropriate department and by the Dean of Faculty. They may have recently completed training or be established investigators wishing to devote major research effort to cystic fibrosis. The beginning investigator should have demonstrated promise of ability to initiate and carry out independent research and the established investigator should have a published record of excellent scientific research.

Level of Study: Doctorate, Postgraduate

Type: Scholarship

Value: Salary support, which is dependent on the qualifications and experience of the successful candidate, will be determined by prevailing Canadian scholarship rates and the nominating university Length of Study: 3 years, renewable for an additional 2 years on receipt of a satisfactory progress report. In no case will an award be for more than 5 years

Frequency: Every 2 years

Study Establishment: Any approved university, hospital or research institute

Country of Study: Canada

No. of awards offered: Varies, subject to availability of funds Application Procedure: Application form is available at www. cysticfibrosis.ca/en/research/ApplicationForms.php. Applicants must write for details.

Closing Date: October 1st

Funding: Foundation

Additional Information: Applications will be accepted only in oddnumbered years.

\section{CFC Senior Scientist Research Training Award}

Subjects: Cystic fibrosis.

Purpose: To provide support to a limited number of cystic fibrosis investigators by offering them an opportunity to obtain additional training that will enhance their capacity to conduct research directly relevant to cystic fibrosis

Eligibility: Applicants must have held a recognized, full-time faculty appointment in a relevant discipline at a Canadian university or hospital for at least 6 years.

Level of Study: Postgraduate

Type: Training award

Value: The amount of the award, a maximum of $\$ 15,000$

Length of Study: 3 months to 1 year

Frequency: Annual

Study Establishment: An approved university department or hospital in Canada

Country of Study: Canada

Application Procedure: Applications must be received by the

Foundation no later than the deadline. Incomplete or late applications will be returned to the applicant. 
Closing Date: April 1st and October 1st

Funding: Foundation

Additional Information: This award can be used for sabbatical support for qualified individuals.

\section{CFC Small Conference Grants}

Subjects: Cystic fibrosis.

Purpose: To support small conferences that are focused on subjects of direct relevance to cystic fibrosis and to facilitate the exchange of special expertise between larger, university-based cystic fibrosis clinics and smaller, more remote clinics.

Eligibility: Open to clinic directors and CFC-funded investigators. Level of Study: Professional development

Type: Grant

Value: Grants to conferences will be up to a maximum of Canadian $\$ 2,500$ and grants for the exchange of expertise will not normally exceed Canadian $\$ 1,000$

No. of awards offered: Dependent on availability of funds Application Procedure: Applicants must make applications in the form of a letter. For medical and/or scientific conferences, the application should indicate who is organizing and attending the conference, and the specific topics and purpose of the conference.

For inter-clinic exchanges, the application should specify the proposed arrangements for, and the specific purpose of the exchange.

Closing Date: Applications may be submitted at any time, but the Foundation should be consulted in advance with respect to the availability of funds

No. of awards given last year: 1

No. of applicants last year: 1

Additional Information: Grants are available on a first-come, firstserved basis. Frequency of application from any particular individual or group should be reasonable.

\section{CFC Special Travel Allowances}

Subjects: Cystic fibrosis.

Purpose: To enable CCFF-funded fellows and students to attend and participate in scientific meetings related to cystic fibrosis.

Eligibility: Open to Cystic Fibrosis Canada-supported fellows and students, for each year of their award, upon written application and pending the availability of funds.

Level of Study: Postgraduate, Doctorate

Type: Award

Value: Up to Canadian $\$ 1,200$ annually

Length of Study: As determined by seminar length

Frequency: Annual

Study Establishment: Appropriate seminar

Country of Study: Any country

Application Procedure: Applications should be made in the form of a letter and must be submitted prior to travel.

Closing Date: Any time, but the foundation must be consulted in advance

Funding: Foundation

\section{CFC Studentship Awards}

Subjects: Cystic fibrosis.

Purpose: To support highly qualified graduate students who are registered for a higher degree, and who are undertaking full-time research training in areas of the biomedical or behavioural sciences relevant to cystic fibrosis.

Eligibility: Applicants must be highly qualified graduate students who are registered for a higher degree and who are undertaking full-time research training in areas relevant to cystic fibrosis, or highly qualified students who are registered in a joint MD/MSc or MD/PhD programme. Equitable consideration will be given to studentship applicants from outside of Canada who intend to return to their own country on completion of a studentship.

Level of Study: Doctorate, Postgraduate

Type: Studentship

Value: Salary and cost-of-living award at the discretion of the Medical/ Scientific Advisory Committee

Length of Study: 2-3 years (Master's level) and 2-5 years

(Doctorate level)

Frequency: Annual

Study Establishment: Studentships are tenable only at Canadian universities
Country of Study: Canada

Application Procedure: Cystic Fibrosis Canada sponsors a studentship competition in October and April. Candidates for initial awards are eligible to apply to either competition. Similar to all CFC grants, studentships are subject to the availability of funds, and the availability of funds is generally more certain with respect to the October competition.

Closing Date: October 1st

Funding: Foundation

Additional Information: Studentships are awarded for studies at the Master's or doctoral level. If a student receiving support for studies leading to a Master's degree elects to continue to a doctorate degree, he or she must reapply for an initial CFC studentship at the doctoral level.

\section{Clinical Fellowships}

Subjects: Cystic fibrosis care.

Purpose: Intended for those individuals who have already obtained their clinical training and wish to pursue training in CF care, and also acquire the competence that would allow them to participate in clinical trials.

Eligibility: Canadian citizens or permanent residents who have an MD degree, have recently completed their clinical training and have obtained medical licensure in Canada are eligible to apply.

Level of Study: Research, MD degree

Type: Fellowship

Value: Depends on academic qualifications and/or research experience

Length of Study: 2 years, fellows can apply for 1 year renewal for further research training

Country of Study: Canada and abroad

No. of awards offered: 1

Application Procedure: Applicants must submit three letters of recommendation, one of which should be from the applicants' current or most recent supervisor. The application form should also include a description of the proposed research and clinical training program and official transcripts of the applicants' complete academic record. Applications that do not include these documents will be rejected. Closing Date: October 1st

\section{Clinical Project Grants}

Purpose: Intended to bolster the CFC's commitment to clinical research and to promote the further development of the Clinical Studies Network. It provides a mechanism whereby the most important ideas for clinical studies can be forged into viable protocols and strategies of urgent clinical relevance can be pursued (seed money for small, start-up pilot projects).

Eligibility: Awarded at the discretion of the leaders of the Scientific Peer Review Panel in consultation with the Clinical Studies Network. Level of Study: Research

Type: Grant

Value: Up to $\$ 15,000$

Frequency: Dependent on funds available

No. of awards offered: Varies

Application Procedure: Applications should be made in the form of a letter in which a clear hypothesis is detailed, relevance to CF is demonstrated, and a brief budget is outlined.

Closing Date: February 1st (Notice of Intent to apply) and April 1st (Full Application deadline)

Additional Information: Applications may be submitted at any time but the Foundation should be consulted in advance with respect to the availability of funds.

\section{Travel Supplement Grants for the European CF Society Conference}

Purpose: To assist a limited number of individuals who plan to play an active role in ECFS conferences.

Eligibility: Applicants must be CFC-funded investigators, Canadian CF clinic directors or clinicians, or Canadian CF clinic coordinators and allied health professionals. Applicants must show evidence of active participation at the conference.

Type: Grant

Value: Up to Canadian $\$ 2,000$ per person

Frequency: Annual 
No. of awards offered: Up to 5

Application Procedure: Applications should include a brief budget and frequency of application from any particular individual should be reasonable (once every 4 years). Completed application form and supporting documentation can be submitted by email or hard copy. Application form is available at website also. Incomplete or late applications will be returned to the applicant.

Closing Date: February 1st (for Basic Science Conference) and April 1st (for ECFS Conference)

Additional Information: Please contact at info@cysticfibrosis.ca for more information.

\section{Visiting Allied Health Professional Awards}

Subjects: Cystic fibrosis.

Purpose: To support allied health professionals from abroad who are invited to engage in CF clinical observation or activity at a Canadian institution or Canadian allied health professionals who wish to visit another clinic in Canada or abroad.

Eligibility: Applicants must be associated with a recognized CF clinic, and be an active member in CF clinical care. It is intended that this experience will in some way benefit Canadian CF clinical care.

Type: Award

Frequency: Dependent on funds available

Country of Study: Canada or abroad

No. of awards offered: Varies

Application Procedure: Applications should be made in the form of a letter, accompanied by a supporting letter from the head of the appropriate department of the applicants' institution. A supporting letter signed by the department head of the host institution should also be provided.

Closing Date: Application by letter at any time throughout the year Additional Information: Applications may be submitted at any time, but CFC should be consulted in advance with respect to the availability of funds.

\section{Visiting Clinician Awards}

Subjects: Cystic fibrosis.

Purpose: To support clinicians from abroad who are invited to engage in CF clinical observation or activity at a Canadian institution or Canadian clinicians who wish to visit another clinic in Canada or abroad.

Eligibility: Applicants must be associated with a recognized CF clinic, and be an active member in CF clinical care. It is intended that this experience will in some way benefit Canadian CF clinical care.

Type: Award

Frequency: Dependent on funds available

No. of awards offered: Varies

Application Procedure: Applications should be made in the form of a letter, accompanied by a supporting letter from the head of the appropriate department of the applicants' institution. A supporting letter signed by the department head of the host institution should also be provided.

Closing Date: Application by letter at any time throughout the year Additional Information: Applications may be submitted at any time, but CFC should be consulted in advance with respect to the availability of funds. 